H I LGA RDIA

A Journal of Agricultural Science Publisbed by the California Agricultural Experiment Station

\title{
THE TETRANYCHOID MITES OF AFRICA
}

EDWARD W. BAKER

and

A. EARL PRITCHARD

UNIVERSITY OF CALIFORNIA · BERKELEY, CALIFORNIA 
Seventy-one species of plant-feeding mites of the superfamily Tetranychoidea are known to occur in Africa and Mauritius. Keys are provided for their identification, and records of their occurrence in this part of the world are presented.

The following new species are described. Tetranychidae:

Petrobia moutiai, Eutetranycbus cratis, E. bredini, E. clastus, E. enodes, E. apheles, Eotetranychus cactorum, E. ancora, $E$. cernuus, E. cypbus, E. cybebus, Scbizotetranychus reticulatus, S. spiculus, S. sacrales, S. gausus, S. rbodanus, Oligonychus licinus, O. calcis, O. simus, O. tylus, O. saccharinus, O. grypus, $O$. plegas, Tetranychus tumidosus, $T$. andrei, $T$. macfarlanei, $T$. evansi, $T$. sayedi, $T$. browningi, $T$. lombardinii. Tenuipalpidae:

Tenuipalpus attiabi, $T$. lawrencei. 


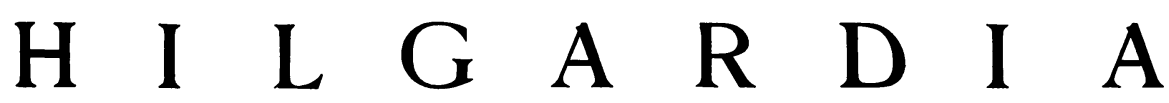 \\ A Journal of Agricultural Science Published by \\ the California Agricultural Experiment Station}

\section{THE TETRANYCHOID MITES OF AFRICA ${ }^{1}$}

\section{EDWARD W. BAKER ${ }^{2}$ and A. EARL PRITCHARD ${ }^{3}$}

Tetranychoid mites are plant feeders of considerable economic importance. Most of the species feed on the leaves, injuring the epidermis with their cheliceral stylets. Heavy infestations result in a blotching, stippling, or bronzing of the leaves, sometimes accompanied by leaf fall; and fruit may be scarred.

With the use of organic insecticides in recent years, these mites have become of increasing concern to agriculture. Species that were unknown to science a few years ago are now subject to chemical control. The development of new agricultural areas in countries such as Africa encourages large populations of still other new species. Thus there is an increasing problem with regard to quarantine aspects of the commercial transportation of live plants and their produce throughout the world.

There is very little published information concerning the tetranychoid mites of Africa. Prior to this study, nine species of spider mites were known from Egypt and the Sudan, and only eight species from Africa south of the Sudan. In this article fifty species of spider mites are recognized from Africa and the island of Mauritius, including thirty new species.

T'wenty-one species of false spider mites are now known from Africa, of which eight are Palaearctic in distribution. Two new species from the Belgian Congo are described.

The present knowledge of tetranychoid mites is based largely on field collections made by the senior author, particularly in the Belgian Congo, and the survey of Mauritius made by L. A. Moutia.

The synonymical references are limited to those pertaining to the original descriptions and those directly concerned with records of the tetranychoid mites from Africa or Mauritius. Baker and Pritchard (1953a) and Pritchard and Baker $(1955,1958)$ cite complete references for each of the previously known species, the genera, and suprageneric categories.

\footnotetext{
${ }^{1}$ Received for publication November 26, 1958.

${ }^{2}$ Acarologist, United States Department of Agriculture, Agricultural Research Service, Entomology Research Division, Washington, D.C.

${ }^{3}$ Associate Professor of Entomology, University of California, and Associate Entomologist in the Experiment Station, Berkeley.
} 


\section{SUPERFAMILY TETRANYCHOIDEA RECK, 1952}

Tetranychoidea Reck, 1952, Soobsh. Akad. Nauk Gruz. S.S.R. 13(7): 419.

Members of the superfamily Tetranychoidea are prostigmate mites that are characterized by having the movable digits of the chelicerae needlelike, strongly recurved proximally, and arising from an eversible pouch, the stylophore. All feed on higher, live plants.

\section{Key to Families}

1. Palpus with a clawlike appendage on fourth segment........... 2

- Palpus simple, without a "claw"............ Tenuipalpidae (p. 560)

2. Hysterosoma with 26 or 27 pairs of setae, a series of the caudal ones being filamentous ................. Tuckerellidae (p. 559)

- Hysterosoma with 9 to 12 pairs of setae and none flagellate

Tetranychidae (below)

\section{FAMILY TETRANYCHIDAE DONNADIEU, 1875}

Tétranychidés Donnadieu, 1875, Recher. Serv. Hist. Tetranych., p. 9.

The family Tetranychidae may be recognized by having a clawlike development on the fourth palpal segment and by having from 12 to 16 pairs of setae on the dorsum of the idiosoma. The higher members of the group are able to produce silken strands.

\section{Key to Genera}

1. Propodosoma with four pairs of dorsal setae and hysterosoma with 12 pairs of setae; true claw uncinate and bearing tenent hairs medially ...........................

- Propodosoma with three pairs of dorsal setae and hysterosoma with nine or ten pairs of setae; true claw padlike with a terminal pair

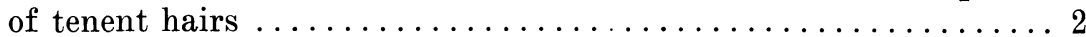

2. Empodium with two ventrally directed rows of tenent hairs....... 3

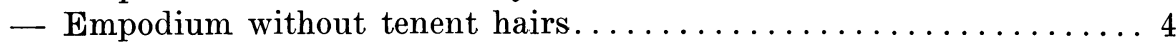

3. Empodium padlike...................Aplonobia (p. 457)

- Empodium clawlike ................................

4. Empodium a tiny rounded protuberance; tarsus I with a loosely associated pair of duplex setae dorsally.......Eutetranychus (p. 460)

- Empodium well developed; tarsus I with two pairs of duplex setae

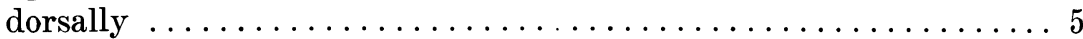

5. Opisthosoma with two pairs of para-anal setae............6

- Opisthosoma with a single pair of para-anal setae ............8

6. Empodium clawlike and with three pairs of proximoventral hairs

Panonychus (p. 471)

- Empodium not as above ..................... 7

7. Empodium (excluding legs I and II of male) consisting of three pairs of hairs ..................Eotetranychus (p. 473)

- Empodium clawlike and bifid ............Schizotetranychus (p. 486)

8. Empodium clawlike, about as long as or longer than proximoventral hairs 
- Empodium consisting of three pairs of hairs, the proximodorsal spur short when present ..................... Tetranychus (p. 529)

GENUS BRYOBIA KOCH, 1836

Bryobia Koch, 1836, Deuts. Crust. Myr. Arach. 1: 8, 9.

The genus Bryobia may be recognized by having the true claws uncinate and bearing mediolateral tenent hairs. The propodosoma bears four pairs of setae, and in the two known African species the anterior two pairs of these are borne on a lobed projection. Females of these species are quite similar.

\section{Bryobia rubrioculus (Scheuten)}

Sannio rubrioculus Scheuten, 1857, Arch. Naturg. 23(1): 104.

Eyndhoven (1956) proposed that Scheuten's name rubrioculus be applied to the fruit-tree form of the Bryobia praetiosa complex. This is the same form described by Morgan and Anderson (1957) as B. arborea. Dr. Morgan informs us that our specimens from South Africa closely resemble specimens of Bryobia found on fruit trees in Europe and North America.

We have seen representatives of this species from South Africa collected at Elgin, Western Cape Provinee, summer 1950-51, on Ohenimuri apple.

\section{Bryobia cristata (Dugès)}

Tetranychus cristata Dugès, 1834, Ann. Sci. Nat. Paris (sér. 2) 1: 15, 28. Bryobia urticae Sayed, 1946, Bul. Soc. Fouad $1^{\text {er }}$ Ent. 30: 86.

This species is definitely known only from Europe and North Africa. An examination of some of Sayed's specimens of Bryobia urticae from Dokki, near Cairo, Egypt, on weeds, shows that his illustration of empodium I of the female is erroneous and that urticae is a synonym of $B$. cristata as redescribed by Eyndhoven (1957). B. cristata differs from B. rubrioculus most obviously in that the dorsal setae of the body of the larvae of $B$. cristata are slender and lanceolate rather than short and broadened. Males of B. cristata are common, whereas this sex is unknown for B. rubrioculus.

\section{GENUS APLONOBIA WOMERSLEY, 1940}

Aplonobia Womersley, 1940, Trans. Roy. Soc. S. Austral. 64: 252.

The padlike base of the true claw, the padlike empodium bearing two rows of tenent hairs, and the absence of a differentiated area on the dorsal integument of the hysterosoma are characters distinguishing Aplonobia from other tetranychid genera. A single representative of this genus is known from Africa.

\section{Aplonobia histricina (Berlese)}

Tetranychopsis histricina Berlese, 1910, Redia 6: 243.

Aplonobia histricina is common on Oxalis in orchards of southern Australia. A knowledge of the occurrence of this species under similar conditions in South Africa is based on collections from Stellenbosch, Union of South Africa, September 9, 1958 (P. J. Kriegler), on Oxalis pes-caprae; and from Bien Donné, Groot Drakenstein, Cape Province, South Africa, April 8, 1953 (M. B. Georgala), on pear. 


\section{GENUS PETROBIA MURRAY, 1877}

Petrobia Murray, 1877, Econ. Ent., Aptera, p. 118.

The genus Petrobia may be recognized by the clawlike empodium bearing two rows of tenent hairs. The true claws are padlike, each with a terminal pair of tenent hairs. Three species are here recognized from the Ethiopian Region, of which two are more or less cosmopolitan and one is new to science.

\section{Key to Species: Females}

1. Idiosoma with dorsal setae short, not set on tubercles........ (1) latens

- Idiosoma with dorsal setae very long and set on large tubercles.... 2

2. Empodial claw long, bent much beyond level of end of pad of true claw ; idiosoma with dorsal integument transversely striate ... (2) harti

- Empodial claw short, sharply bent at level of end of pad of true claw; idiosoma with dorsal integument rugose...........(3) moutiai

\section{Petrobia latens (Müller)}

Acarus latens Müller, 1776, Zool. Dan. Prodr., p. 187.

Petrobia cephae Sayed, 1946, Bul. Soc. Fouad 1 ${ }^{\text {er }}$ Ent. 30: 79.

Petrobia latens feeds primarily on grasses and grains and is sometimes an important economic pest in the late winter or spring. It is known to occur in Europe, Africa, North America, and Australia.

Sayed (1946) recorded this species from Upper Egypt, on onions, under the name Petrobia cephae Sayed. Specimens from Africa that we have studied are from Gutu, Southern Rhodesia, August, 1932 (A. Cuthbertson), on wheat.

\section{Petrobia harti (Ewing)}

Neophyllobius harti Ewing, 1909, Trans. Amer. Ent. Soc. 35: 405.

Petrobia harti (Ewing), Moutia, 1958, Bul. Ent. Res. 49: 59.

Tetranychina agerati Sayed, 1946, Bul. Soc. Fouad $1^{\text {er }}$ Ent. 30: 83.

Petrobia harti feeds primarily on Oxalis, although adults and eggs are sometimes found on neighboring plants. This species is known from North America, Japan, Australia, the Middle East, and Africa.

Sayed (1946a) recorded this species from Egypt under the name Tetranychina agerati. We have studied specimens recorded from Mauritius by Moutia.

\section{Petrobia moutiai, new species}

(Figs. 1, 2)

Petrobia sp., Moutia, 1958, Bul. Ent. Res. 49: 59.

Petrobia moutiai resembles P. zachvatkini (Reck and Bagdasarian) (Armenia), differing in that the dorsal setae of the body are filiform rather than acutely tapering from the base. It differs from other members of the genus in that the dorsal setae of the body are borne on strong tubercles and the empodial claw is very strong, short, and sharply bent. 
Female. Rostrum reaching middle of femur I. Peritreme with a complex enlargement distally. Legs with tactile setae serrate, those on proximal segments long and subspatulate, the more distal ones slender and pointed; legs

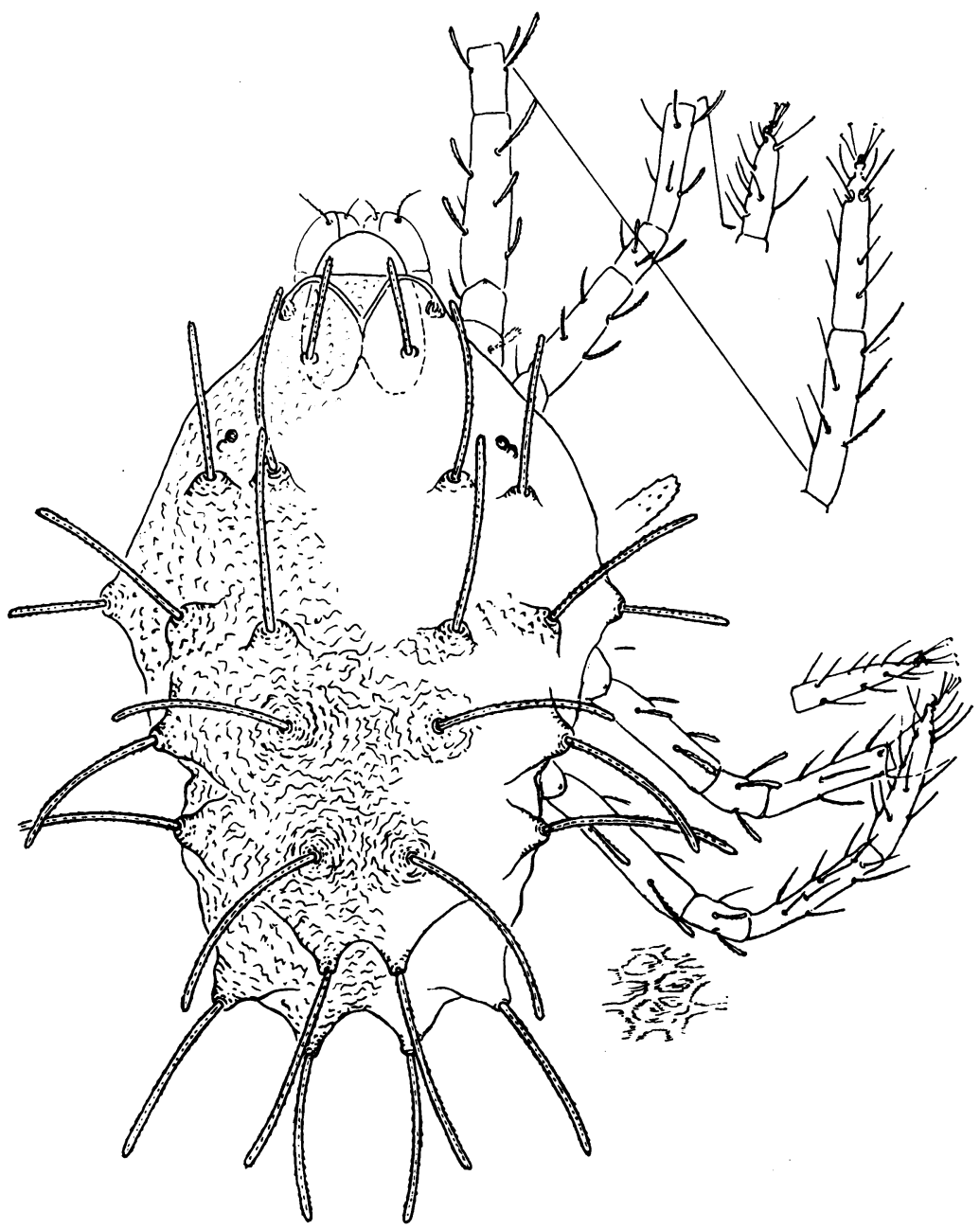

Fig. 1. Petrobia moutiai: dorsal aspect of female.

I shorter than length of body. Empodium a short, strong claw, sharply bent at level of end of pad of true claw, bearing seven pairs of tenent hairs. Idiosoma with dorsal integument irregularly rugose, the dorsal setae borne on strong tubercles, very long, filiform, serrate, with the anterior propodosomals and humerals shorter than the others. Length of body $580 \mu$; greatest width of body $338 \mu$. 
Male. Similar to female. Legs I about as long as body. Second dorsal propodosomals and sacrals shorter. Aedeagus aciculate. Length of body $430 \mu$.

Holotype. Female, Beau Songe, Mauritius, October 10, 1954 (L. A. Moutia), on Verbena bonariensis; in the British Museum (Natural History).

Paratypes. Two females, 3 males, Beau Songe, Mauritius, October 10, 1954 (L. A. Moutia), on Verbena bonariensis.

This species is named in honor of L. André Moutia, Department of Agriculture, Mauritius.
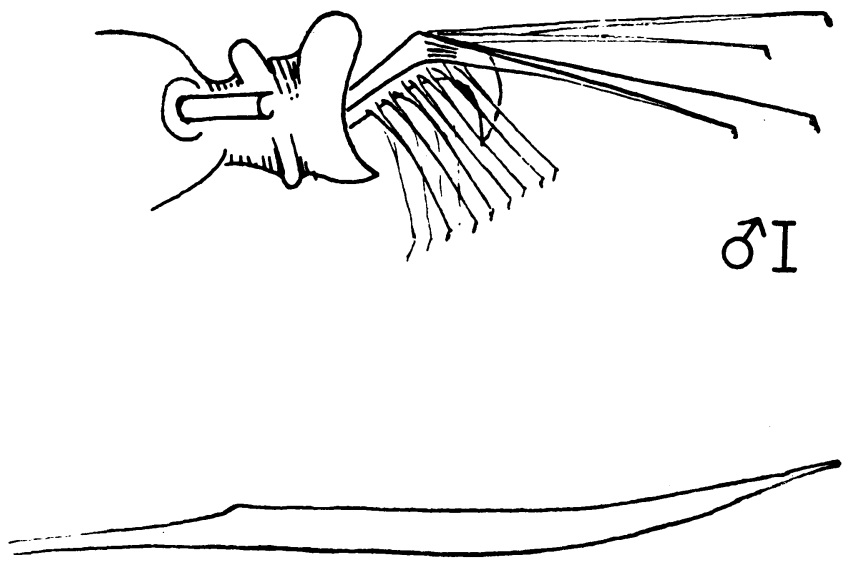

Fig. 2. Petrobia moutiai: appendages of tarsus I of male and aedeagus.

\section{GENUS EUTETRANYCHUS BANKS, 1917}

Neotetranychus (Eutetranychus) Banks, 1917, Ent. News 28: 197.

The genus Eutetranychus may be recognized by having the empodium reduced to a small, rounded protuberance. Tarsi I and II lack the characteristic duplex setae, and the hysterosoma bears a characteristic pore caudolaterad of the first dorsolateral seta.

Eutetryanchus banksi (McGregor) is restricted to the New World, although Pritchard and Baker (1955) indicated that it occurred in Africa. The Old World species that were considered by us under the name $E$. banksi may be readily differentiated by having the inner sacral setae forming a square with the third dorsal propodosomals rather than being much more widely spaced.

\section{Key to Species: Females}

1. Idiosoma with dorsal setae set on strong protuberances.........2

- Idiosoma with dorsal setae set on small tubercles.............. 3

2. Hysterosoma with a "basket-weave" pattern between the dorsocentral setae ............................... (1) cratis

- Hysterosoma without wartlike elevations between the dorsocentral setae (2) africanus 
3. Dorsocentral hysterosomal setae broadened and blunt distally..... 4

- Dorsocentral hysterosomal setae long and acutely tapering. (3) pantopus

4. Idiosoma with dorsal striae bearing lobes................. 5

- Idiosoma with dorsal striae smooth. .................. 7

5. Propodosoma with mediodorsal striae irregularly anastomosing

(5) bredini

- Propodosoma with mediodorsal striae more or less parallel........6 6

6. Dorsal striae of body with strong lobes ; lateral setae of body short

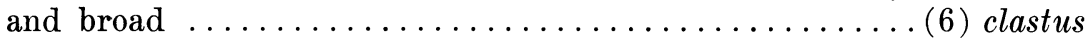

- Dorsal striae of body with weak lobes ; lateral setae of body usually slender and spatulate or subspatulate.............. (4) orientalis

7. Hysterosoma with all three pairs of dorsolateral setae......(7) enodes

- Hysterosoma with first pair of dorsolateral setae absent... (8) apheles

\section{Eutetranychus cratis, new species}

(Fig. 3)

The female and deutonymph of Eutetranychus cratis may be readily separated from all others by the elliptical, wartlike elevations that give a peculiar "basket-weave" appearance to the integument between the dorsocentral hysterosomals.

Female. Stylophore bearing a pair of strong lobes ventrodistally and a dorsodistal protuberance. Peritreme with a concave, bulbous enlargement distally. Palpus without development exterior to dorsal chaeta on first segment. Tibia I with six tactile and one sensory setae; tibia II with five tactile setae. Propodosoma with dorsal integument granulate on anterior part and finely and longitudinally striate on posterior part; hysterosoma with dorsal integument bearing smooth striae, the area between the dorsocentral hysterosomals with elliptical elevations. Idiosoma with dorsal setae all borne on strong, granulated elevations; dorsal setae mostly long, strong, serrate, nearly rodlike, except for short humeral and caudal four setae; inner sacrals distinctly wider apart than third dorsocentrals. Length of body $338 \mu$; greatest width of body $255 \mu$.

Male. Hysterosoma without integumentary elevations between dorsocentrals. Idiosoma with second dorsal propodosomals the longest; the second and third dorsocentral hysterosomals somewhat shorter; the first and third dorsal propodosomals, first dorsocentral and first dorsolateral hysterosomals still shorter; the humeral, last three dorsolateral hysterosomals, and inner sacrals next in size; and the outer sacrals and clunals very short. Aedeagus bent abruptly dorsad and tapering. Length of body $287 \mu$; greatest width of body $160 \mu$.

Holotype. Female, Stanleyville, Belgian Congo, April 18, 1955 (E. W. Baker), on ?Bixa leaf; type no. 2486 in the U. S. National Museum.

Paratypes. Twenty-one males, 25 females, Stanleyville, Belgian Congo; April 18, 1955 (E. W. Baker), on ?Bixa; 2 females, Stanleyville, Belgian Congo, April 18, 1955 (E. W. Baker), on Macaranga sp.

Also examined were nymphs, Leopoldville, Belgian Congo, April 15, 1955 (E. W. Baker), on orange leaf. 


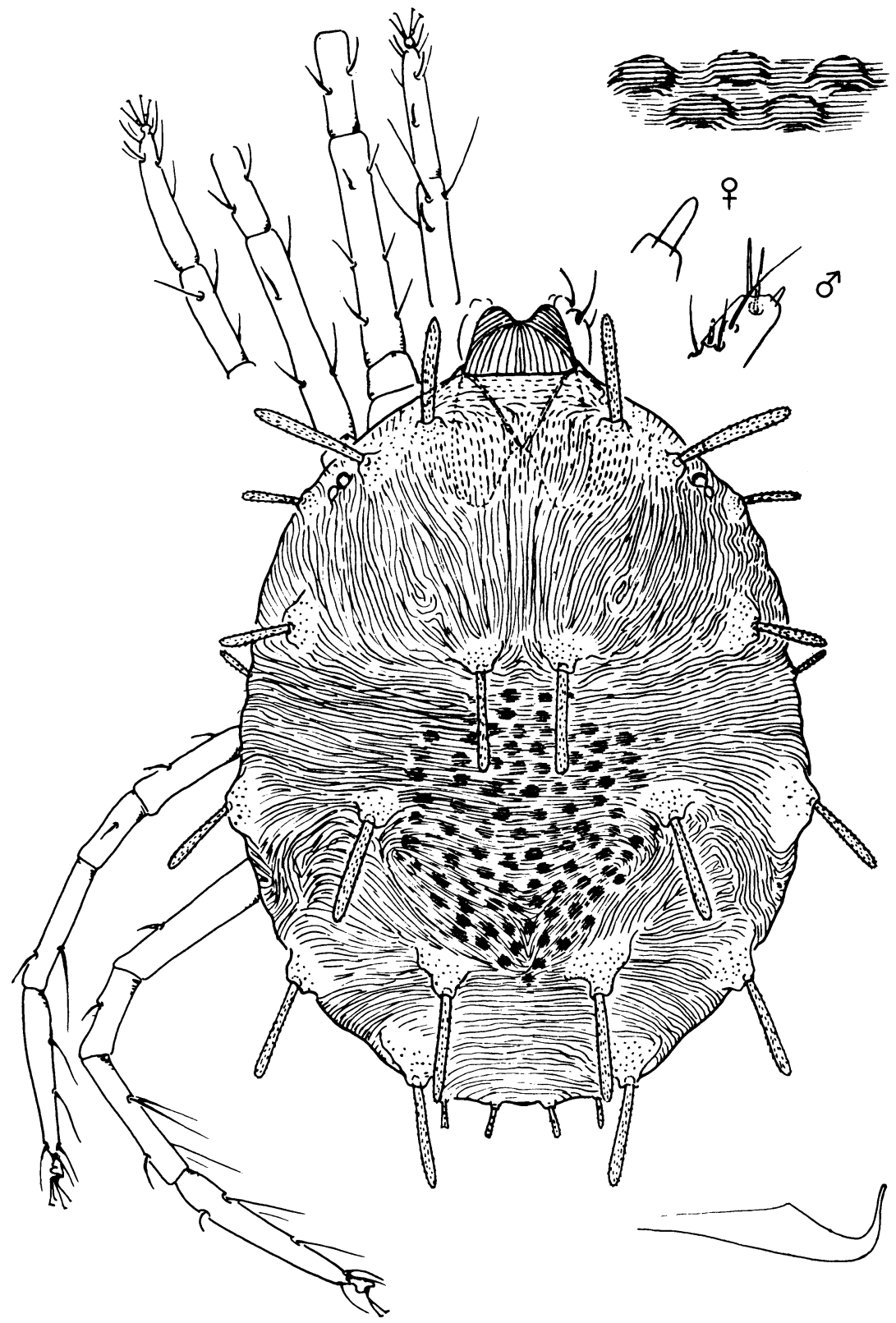

Fig. 3. Eutetranychus cratis: dorsal aspect of female, with enlargements of mediodorsal integument of hysterosoma, female and male palpus, and aedeagus. 


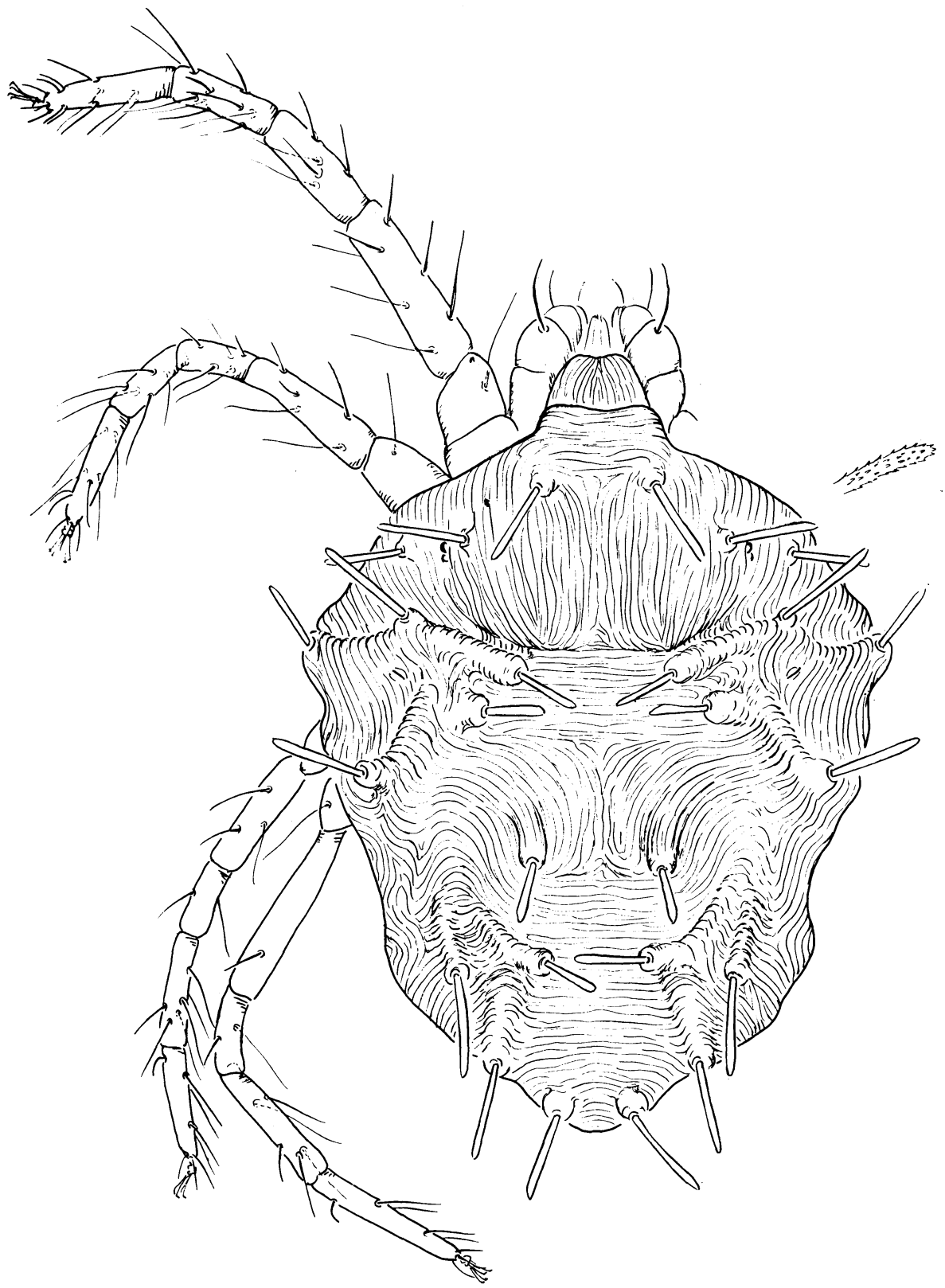

Fig. 4. Eutetranychus africanus: dorsal aspect of female (crumpled by slide preparation). 


\section{Eutetranychus africanus (Tucker)}

(Fig. 4)

Anychus africanus Tucker, 1926, Union So. Afr. Dept. Agric. Div. Ent. Mem. 5: 5 .

Eutetranychus banksi (McGregor), Moutia, 1958, Bul. Ent. Res. 49: 60.

Africanus was originally described on a basis of specimens from Durban, Natal, on oranges, lemons, and frangipani. Our identification of this species is based on the original description; specimens that closely agree with it are from Beau Bassin, Mauritius, on peach and loquat; and from Reduit, Mauritius, on citrus. The females from citrus have much shorter sacral setae than those here figured and the dorsocentral hysterosomals vary to being shorter and more spatulate. Pritchard and Baker (1955) considered this species to be a synonym of Eutetranychus banksi (McGregor).

\section{Eutetranychus pantopus (Berlese)}

Tetranychus pantopus Berlese, 1910, Redia 6: 242.

Anychus latus (Canestrini and Fanzago), Sayed, 1946, Bul. Soc. Fouad $1^{\mathrm{er}}$

Ent. 30: 143. Misidentification.

Sayed (1946c) considered under the name latus a species of Eutetranychus found in the Sudan. Because of the similarity of Berlese's type males of Tetranychus pantopus to Sayed's drawings of "latus," Pritchard and Baker (1955) applied the name pantopus to the Sudanese species. However, females of pantopus must be collected in Australia before the application of this name to the African forms can be confirmed.

\section{Eutetranychus orientalis (Klein)}

(Fig. 5)

Anychus orientalis [Zacher] Klein, 1936, Bul. Agric. Res. Sta. Rehovoth 21: 3 ; Sayed, 1946, Bul. Soc. Fouad 1 ${ }^{\mathrm{er}}$ Ent. 30: 143.

Anychus ?latus (Canestrini and Franzago), Hirst, 1923, Proc. Zool. Soc. London 1923: 991. Misidentification.

Anychus latus (Canestrini and Fanzago), Sayed, 1942, Bul. Soc. Fouad $1^{\mathrm{er}}$ Ent. 26: 125. Misidentification.

Anychus ricini Rahman and Sapra, 1940, Proc. Ind. Acad. Sci. 11 (Ser. B): 194. New synonymy.

Eutetranychus monodi André, 1954, Bul. Inst. Franc. Afr. Noire (sér. A)

16: 859. New synonymy.

Females of Eutetranychus orientalis have the dorsal striae of the propodosoma more or less parallel and slightly but distinctly lobed. The dorsal setae of the body are set on small tubercles, and the lateral setae of the body usually are moderately slender and spatulate. However, they vary to being longer, very slender and subspatulate (appearing almost tapering when seen in profile), or else they vary to being shorter and more decidedly spatulate. These variations are encountered within individual collections.

Anychus orientalis was a manuscript name of Zacher's that was validated by Klein (1936), and we have studied some of Klein's specimens from Israel. 


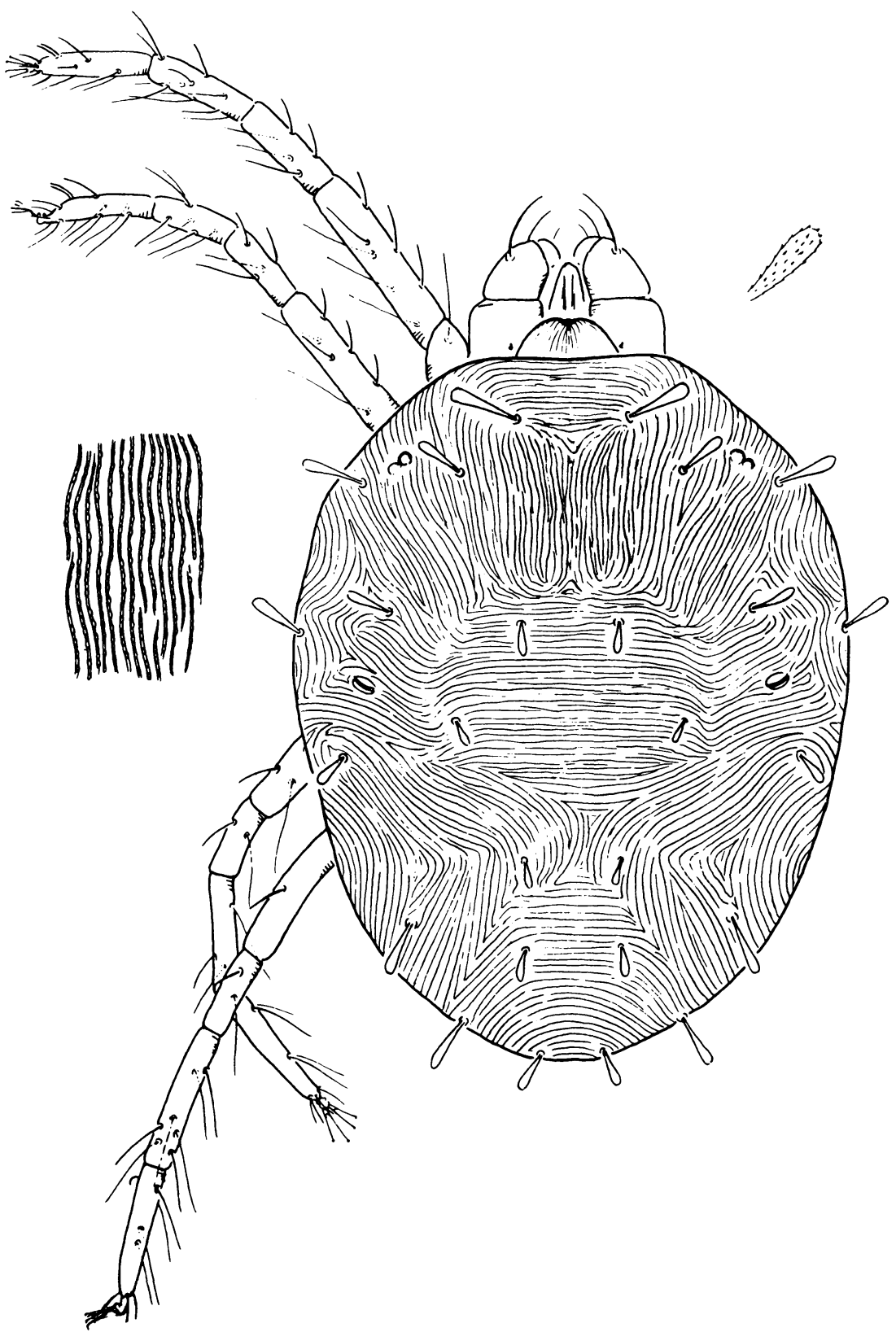

Fig. 5. Eutetranychus orientalis: dorsal aspect of female from Juba, Sudan, on frangipani, with enlargement of mediodorsal integument of propodosoma. 


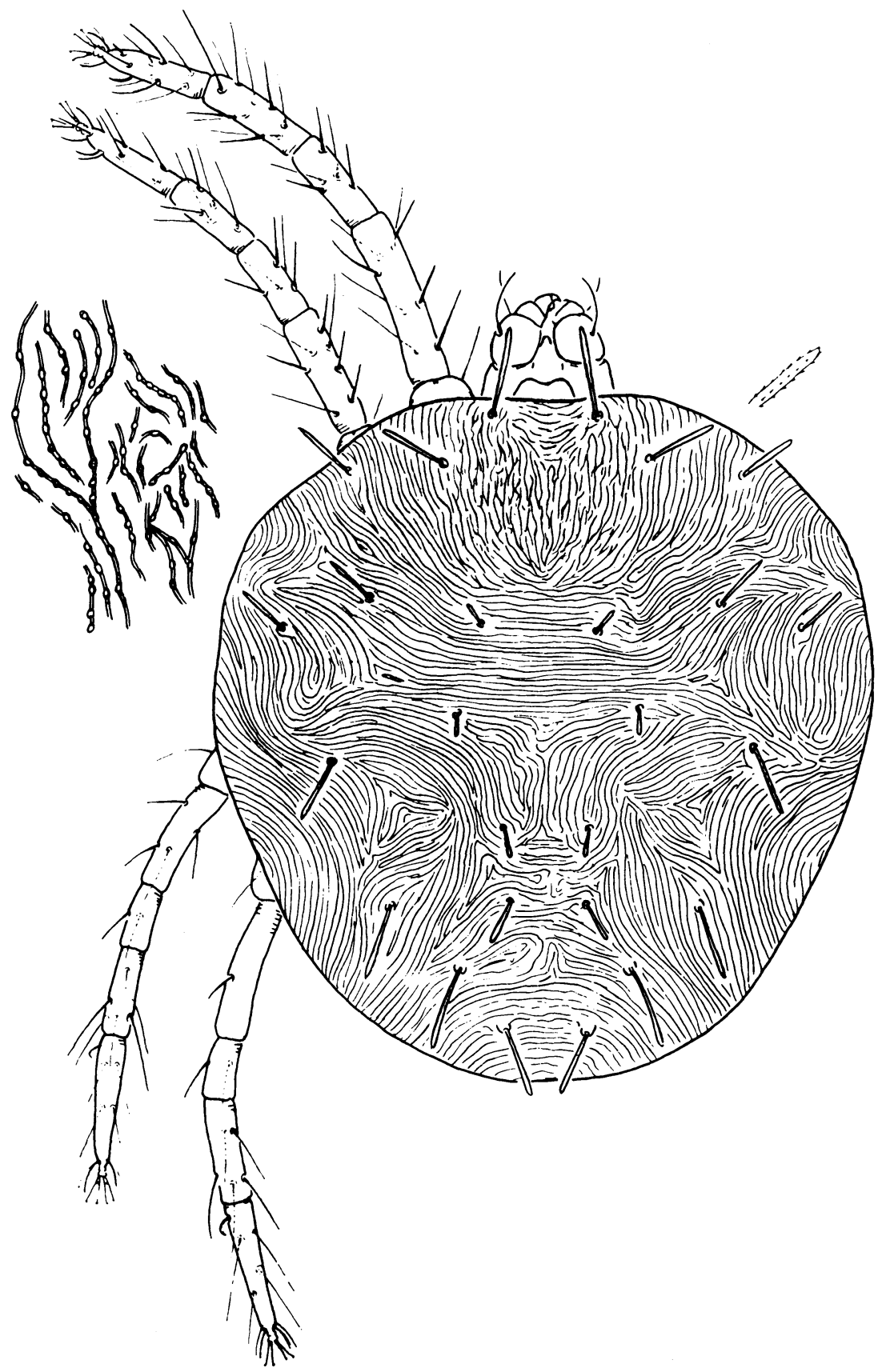

Fig. 6. Eutetranychus bredini: dorsal aspect of female, with enlargement of mediodorsal integument of propodosoma. 
The illustrations of Anychus ricini Rahman and Sapra (1940) agree closely with typical orientalis, and our collections from India represent only orientalis. Therefore, ricini is here considered a synonym of orientalis. André's figures of Eutetranychus monodi from Dakar closely resemble the variants having long and slender dorsolaterals, and monodi is here considered to be a synonym of orientalis. Hirst (1923) and Sayed (1942d, 1946c) tentatively referred to this species as Anychus latus (Canestrini and Fanzago) after studying material from the Sudan and Egypt respectively. We do not consider this Canestrini and Fanzago name as being applicable to the Tetranychoidea. Pritchard and Baker (1955) considered this species to be a synonym of $E$. banksi (McGregor).

Collections that we have studied are from Kythzea, Cyprus, on squash; Juba, Sudan, on frangipani ; Nuri, Sudan, on grapefruit; Rehovoth, Israel, on lemon; Ahwaz, Iran, on citrus; Jalalabad, Afghanistan, on lemon; Neapur, India, on croton; Bangalore, India, on Euphorbia and Glyceridea; and Taipei, Formosa, on citrus. Another collection from Mayfern, East Transvaal, May 13, 1953 (F. J. Stofberg), on frangipani, indicates that this species has been introduced into South Africa.

\section{Eutetranychus bredini, new species}

\section{(Fig. 6)}

Adults of Eutetranychus bredini may be recognized by the anastomosing striae on the mediodorsal integument of the propodosoma. This species further differs from $E$. orientalis in having more strongly developed lobes on the striae.

Female. Stylophore simple, edentate mediodistally. Peritreme gradually and slightly enlarging distally. Palpus without development exterior to dorsal chaeta on first segment. Tibia I with nine tactile and one sensory setae; tibia II with five tactile setae. Idiosoma with dorsal integument finely striate, the striae bearing obvious, widely separated lobes ; propodosoma with mediodorsal striae anastomosing. Idiosoma with dorsal setae borne on small tubercles; marginal setae all long, slender, slightly enlarged distally, serrate; dorsocentral hysterosomals shorter and more spatulate, particularly the anterior pair ; inner sacrals forming a square with third pair of dorsocentral hysterosomals and somewhat longer than they. Length of body $402 \mu$; greatest width of body $340 \mu$.

Male. Similar to female except dorsal setae of body more tapering. Length of body $380 \mu$; greatest width of body $240 \mu$.

Holotype. Female, Astrida, Ruanda-Urundi, May 22, 1955 (E. W. Baker), on date palm (Phoenix dactylifera); type no. 2487 in the U. S. National Museum.

Paratypes. Seven males, 5 females, Astrida, Ruanda-Urundi, May 22, 1955 (E. W. Baker), on date palm.

This species is named in honor of J. Bruce Bredin, Wilmington, Delaware. 


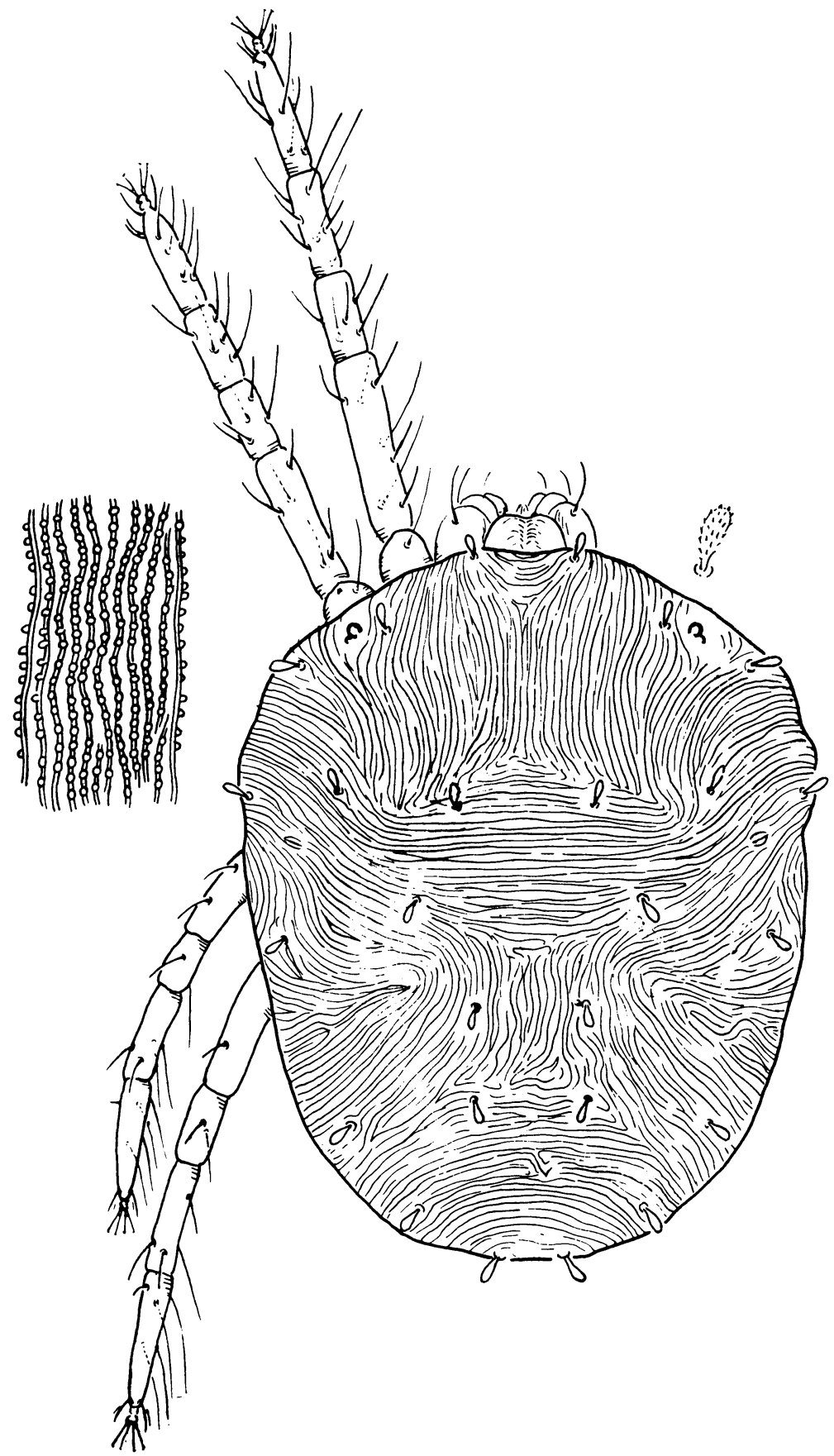

Fig. 7. Eutetranychus clastus: dorsal aspect of female, with enlargement of mediodorsal integument of propodosoma. 


\section{Eutetranychus clastus, new species}

(Fig. 7)

Adults of Eutetranychus clastus may be recognized by having the dorsal striae on the propodosoma more or less parallel and bearing strong lobes. They further differ from $E$. orientalis by having the lateral setae of the body short and broad.

Female. Stylophore with a dorsomedian longitudinal furrow, declivate on distal part and edentate mediodistally. Peritreme gradually and slightly enlarged distally. Palpus without special development exterior to dorsal chaeta. Tibia I with nine tactile and one sensory setae; tibia II with five tactile setae. Idiosoma with dorsal integument finely striate, the striae bearing strong lobes; propodosoma with mediodorsal striae longitudinal and more or less parallel. Idiosoma with dorsal setae borne on small tubercles, dorsolateral setae rather short and strongly spatulate, serrate; dorsocentral hysterosomals similar but smaller; inner sacrals forming a square with third pair of dorsocentrals. Length of body $400 \mu$; greatest width of body $320 \mu$.

Male. Similar to female but lateral setae of idiosoma slenderer, especially the clunals. Length of body $300 \mu$; greatest width of body $200 \mu$.

Holotype. Female, Stanleyville, Belgian Congo, April 18, 1955 (E. W. Baker), on Cassia ?tora; type no. 2488 in the U. S. National Museum.

Paratypes. Thirty-one males, 50 females, Stanleyville, Belgian Congo, April 18, 1955 (E. W. Baker), on Cassia ?tora.

Other specimens studied are from Faradji, Belgian Congo, May 1, 1955 (E. W. Baker), on frangipani.

\section{Eutetranychus enodes, new species}

(Fig. 8)

Adults of Eutetranychus enodes may be recognized by having the dorsal integument of the body with smooth striae and the dorsal setae very short and borne on small tubercles.

Female. Stylophore with a dorsodistal, lobed protuberance. Peritreme with small distal enlargement. Palpus with a tubercle exterior to dorsal chaeta on first segment. Tibia I with nine tactile and one sensory setae; tibia II with six tactile setae. Idiosoma with dorsal integument bearing smooth striae, those on the propodosoma being broken but more or less parallel longitudinally. Idiosoma with dorsal setae borne on small tubercles ; dorsolateral setae short and broad, strongly serrate; dorsocentral hysterosomals very short, slightly widened; inner sacrals forming a square with third pair of dorsocentrals. Length of body $400 \mu$; greatest width of body $287 \mu$.

Male. Similar to female, the dorsal setae of the body longer and slenderer. Aedeagus abruptly bent dorsad, blunt distally. Length of body $331 \mu$; greatest width of body $160 \mu$.

Holotype. Female, Leopoldville, Belgian Congo, April 10, 1955 (E. W. Baker), on raffia palm (Raphia ruffia) ; type no. 2489 in the U. S. National Museum. 


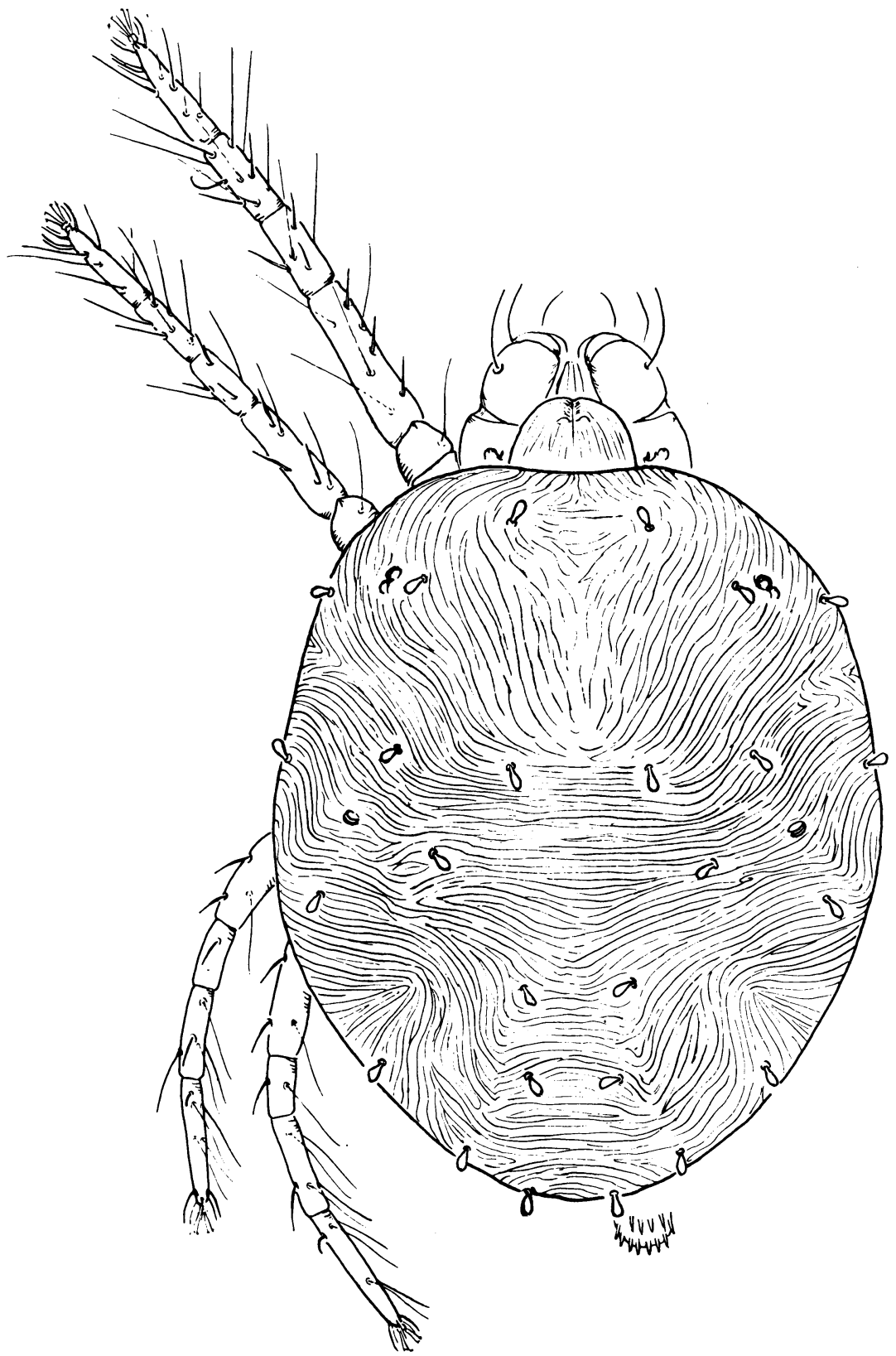

Fig. 8. Eutetranychus enodes: dorsal aspect of female. 
Paratypes. Eight males, 5 females, Leopoldville, Belgian Congo, April 10, 1955 (E. W. Baker), on raffia palm; 1 male, 3 females, Leopoldville, Belgian Congo, April 11, 1955 (E. W. Baker), on Vigna sp.; 6 males, 2 females, Leopoldville, Belgian Congo, April 10, 1955 (E. W. Baker), on Ficus polita; 1 female, Stanleyville, Belgian Congo, April 18, 1955 (E. W. Baker), on palm ; 3 females, Stanleyville, Belgian Congo, April 19, 1955 (E. W. Baker), on manioc (Manihot esculenta); 2 males, 8 females, Stanleyville, Belgian Congo, April 20, 1955 (E. W. Baker), on Ficus sp.; 1 female, Mt. Hoyo, Belgian Congo, May 4, 1955 (E. W. Baker), on peach.

\section{Eutetranychus apheles, new species}

(Fig. 9)

Eutetranychus apheles closely resembles E. cnodes. However, it is the only tetranychid known that lacks the first pair of dorsolateral hysterosomals.

Female. Stylophore strongly declivate anteriorly. Peritreme ending in a simple enlargement. Palpus with a tubercle exterior to dorsal chaeta on first segment. Tibia I with nine tactile and one sensory setae; tibia II with five tactile setae. Idiosoma with dorsal integument finely striate, the striae smooth, and those medially on the propodosoma broken but more or less parallel. Idiosoma with dorsal setae borne on small tubercles; dorsolaterals short and broad, strongly serrate; dorsocentrals smaller and narrower; clunals forming a square with third pair of dorsocentrals ; first pair of dorsolaterals absent. Length of body $490 \mu$; greatest width of body $350 \mu$.

Male. Similar to female, but dorsal setae of body longer and slenderer. Length of body $330 \mu$; greatest width of body $197 \mu$.

Holotype. Female, Beni, Belgian Congo, May 8, 1955 (E. W. Baker), on frangipani (Plumeria sp.); type no. 2490 in the U. S. National Museum.

Paratypes. Thirty-three males, 46 females, Beni, Belgian Congo, May 8, 1955 (E. W. Baker), on frangipani ; 36 males, 36 females, Ruinzori Hotel, Belgian Congo, May 5, 1955 (E. W. Baker), on frangipani.

\section{GENUS PANONYCHUS YOKOYAMA, 1929}

Panonychus Yokoyama, 1929, Saishin Nippon Sangyô Gaichû Zensho: 531.

The genus Panonychus may be recognized by having the dorsum of the body with strong setigerous tubercles and the empodium clawlike with three pairs of proximoventral setae. Ehara (1956) showed that this name has priority over Metatetranychus Oudemans.

One widespread species is known from Africa. We are unable to find any taxonomic or economic article establishing the occurrence of Panonychus ulmi (Koch) on South African fruit trees.

Tetranychus spinigerus Lucas (1849), from Algeria, on snapdragon, was referred to the genus Metatetranychus by Oudemans. The name is a nomen dubium and may represent a species of Aplonobia or Petrobia.

\section{Panonychus citri (McGregor)}

Tetranychus citri MeGregor, 1916, Ann. Ent. Soc. Amer. 9: 28.

Panonychus citri is a pest of citrus and broad-leaved evergreen orna- 


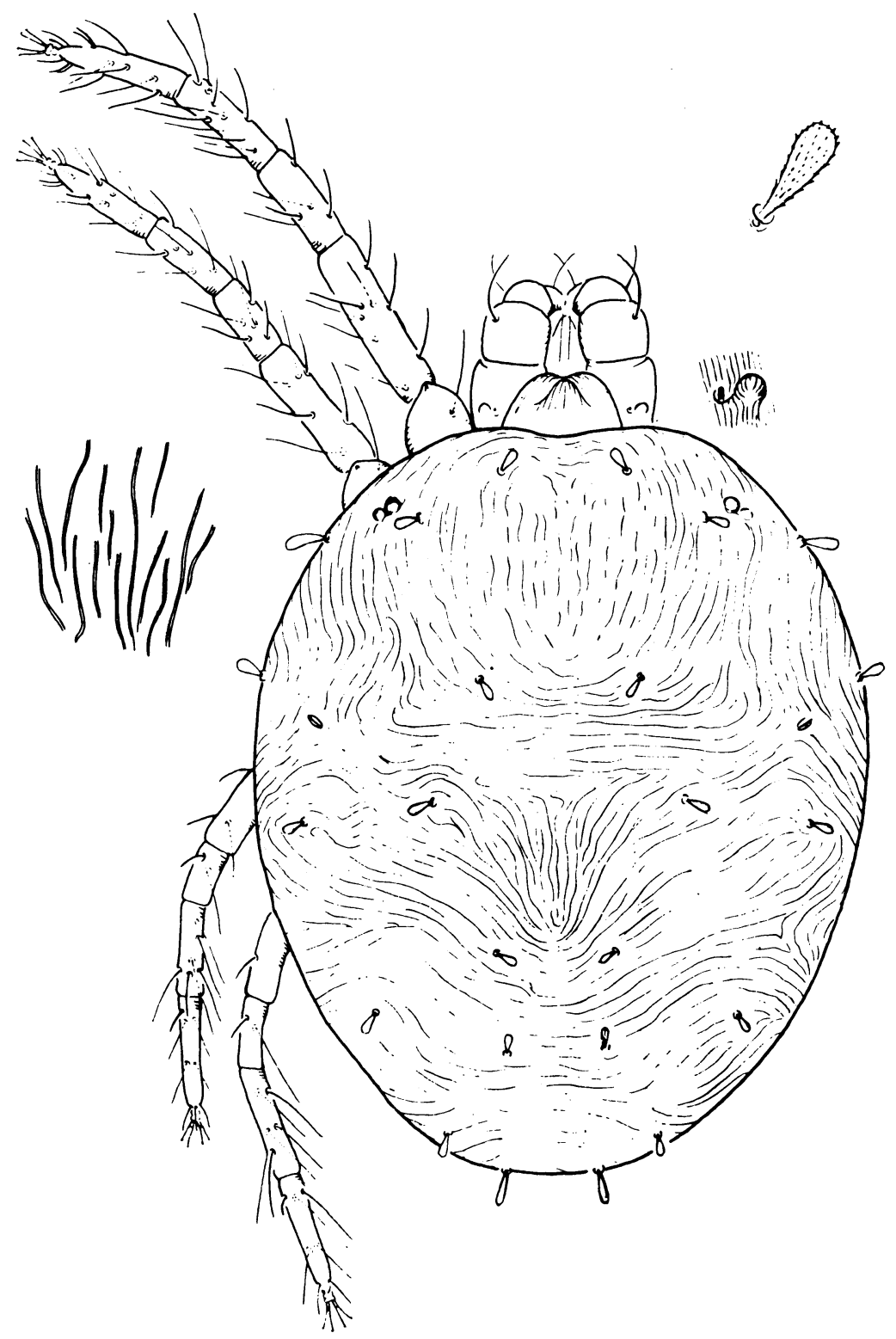

Fig. 9. Eutetranychus apheles: dorsal aspect of female, with enlargement of mediodorsal integument of propodosoma. 
mentals in China, Japan, Ceylon, the Middle East, Florida, Cuba, Bermuda, California, Argentina, New Zealand, and South Africa. It is not known to occur in the Mediterranean area but has been introduced into South Africa. Specimens we have studied are from Rustunburg, Transvaal, June, 1950 (Smit), on citrus.

\section{GENUS EOTETRANYCHUS OUDEMANS, 1931}

Eotetranychus Oudemans, 1931, Ent. Ber. 8(178) : 224.

The genus Eotetranychus may be recognized by having the duplex setae on tarsus I approximate and the empodium consisting of three pairs of hairs of which the ventral pair is slightly stronger. The mites feed in colonies on the underside of leaves, particularly along the midrib and other veins. The adult females are straw colored with dark spots along each side of the body. Their eggs are subglobular, with a short dorsal stipe, and pearly in appearance.

The genus has not previously been recognized from Africa. Five new species are here described.

\section{Key to Species: Males}

1. Aedeagus with an anteroventral angulation on distal part........2

- Aedeagus evenly tapering on distal part.................... 3

2. Shaft of aedeagus curved dorsad; tibia II with five to eight tactile setae ..............................................

- Shaft of aedeagus nearly straight; tibia II with eight tactile setae

(3) cernuus

3. Aedeagus with distal part bent ventrad; tibia II without senory setae. 4

- Aedeagus with distal part bent dorsad ; tibia II with two sensory (and six tactile) setae...................... (1) cactorum

4. Shaft of aedeagus thick and strongly curved dorsad; peritreme hooked distally ........................... (4) cyphus

- Shaft of aedeagus straight; peritreme terminating in simple bulb

\section{Key to Species: Females}

(5) cybebus

1. Hysterosoma with transverse striae between third pair of dorso-

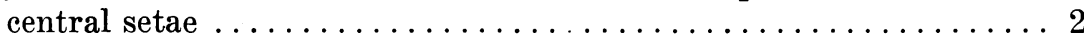

- Hysterosoma with longitudinal striae between third pair of dorsocentral setae .............................. (1) cactorum

2. Peritreme terminating in a simple bulb................ 3

- Peritreme hooked distally......................... (4) cyphus

3. Tarsus I with four tactile setae proximal to duplex setae.... (3) cernuus

- Tarsus I with five tactile setae proximal to duplex setae......... 4

4. Tarsus II with three tactile setae proximal to duplex setae.. (5) cybebus

- Tarsus II with four tactile setae proximal to duplex setae... (2) ancora

\section{Eotetranychus cactorum, new species}

(Figs. 10, 11, 12)

Eotetranychus cactorum is similar to $E$. georgicus (Reck) (Georgia, U.S.S.R.) in that the distal part of the aedeagus is bent abruptly dorsad 
and tapering with the end bent dorsocaudad. The shaft of the aedeagus is much thicker, however, and the dorsal setae of the body are slender and tapering.

Male. Palpus with terminal sensillum stout, a little longer than broad at base. Peritreme terminating in a hook. Tibia I with nine tactile and four

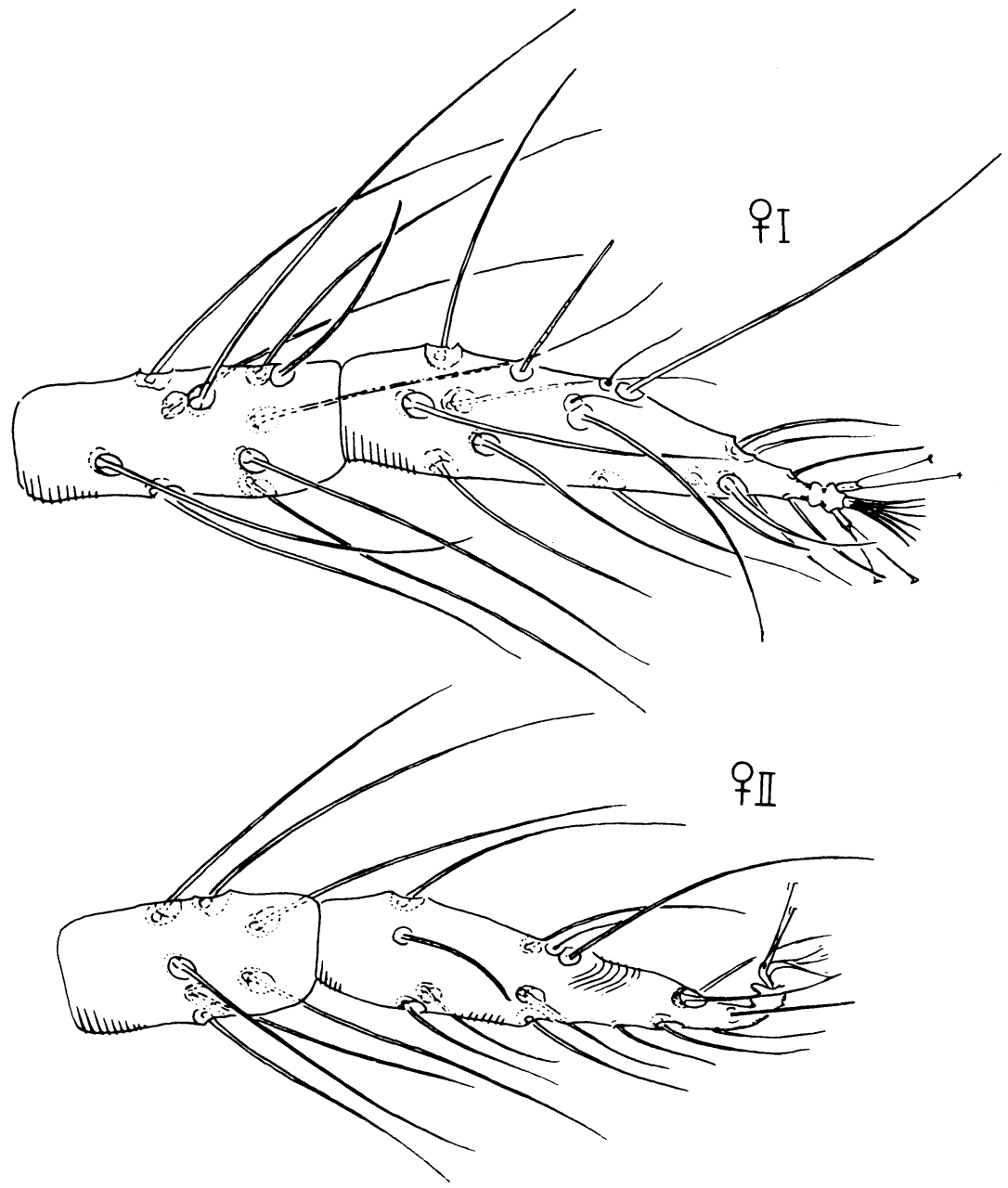

Fig. 10. Eotetranychus cactorum: tibia and tarsus I of female and tibia and tarsus II of female.

sensory setae; tarsus I with four tactile and three sensory setae proximal to duplex setae; empodium I with three pairs of long, stout setae. Tibia II with six tactile and two sensory setae. Body with dorsal setae long, slender, and tapering. Aedeagus with broad, straight shaft, the distal part tapering and bent dorsad with the end bent dorsocaudally. Length of body $306 \mu$; greatest width of body $150 \mu$. 
Female. Palpus with terminal sensillum stout, shorter in length than wide at base. Tibia I with nine tactile and one sensory setae; tarsus I long and slender, with five tactile and one sensory setae proximal to duplexes; tibia II with seven tactile setae. Hysterosoma with longitudinal striae between

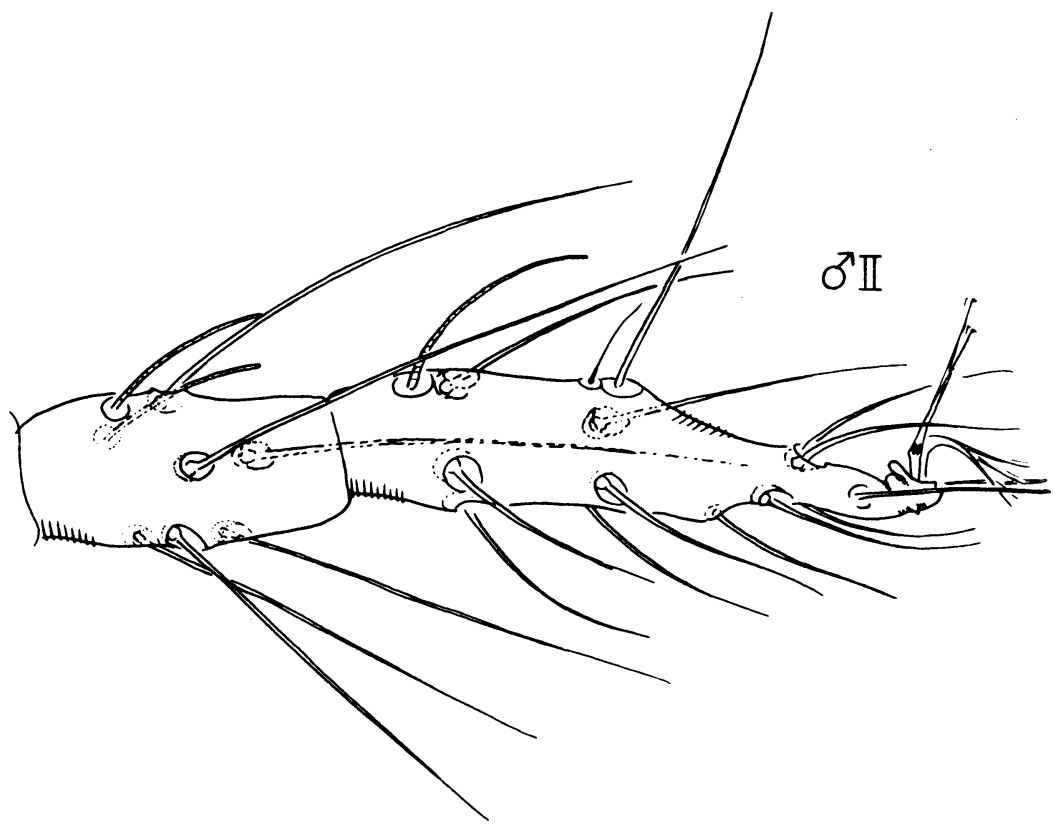

Fig. 11. Eotetranychus cactorum: tibia and tarsus II of male.
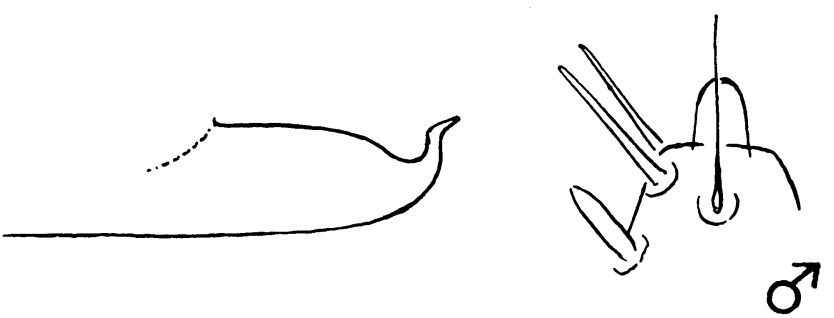

Fig. 12. Eotetranychus cactorum: aedeagus and terminal segment of male palpus.

third pair of dorsocentrals. Length of body $530 \mu$; greatest width of body $255 \mu$.

Holotype. Male, Kysenyi, Belgian Congo, May 11, 1955 (E. W. Baker), on cactus; type no. 2491 in the U. S. National Museum.

Paratypes. Four females; Kysenyi, Belgian Congo, May 11, 1955 (E. W. Baker), on cactus. 


\section{Eotetranychus ancora, new species}

(Figs. 13, 14, 15)

Eotetranychus sp., Moutia, 1958, Bul. Ent. Res. 49: 60.

The aedeagus of Eotetranychus ancora resembles that of $E$. perplexus (McGregor) (western United States) in that it has a terminal enlargement

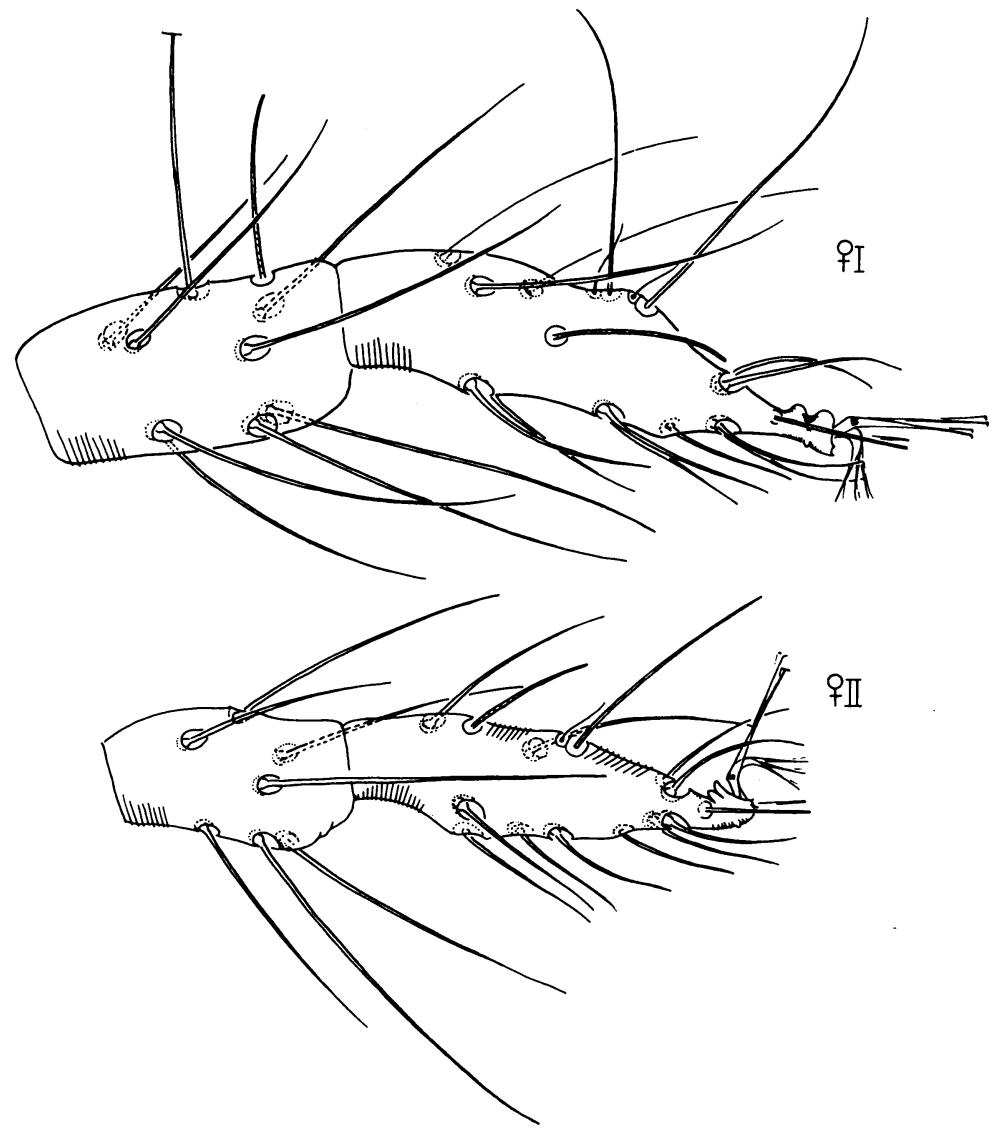

Fig. 13. Eotetranychus ancora: tibia and tarsus I of female and tibia and tarsus II of female.

formed by an anteroventral angulation. However, the shaft of the aedeagus is curved strongly dorsad.

Male. Palpus with terminal sensillum very small. Peritreme terminating in a simple bulb. Tibia I with five tactile and four sensory setae; tarsus I with one tactile and three sensory setae proximal to duplexes; empodium I with the middle pair of hairs strong and the dorsal and ventral pairs of hairs very weak. Tibia. II with five to eight tactile setae. Idiosoma with dorsal setae long, slender, and tapering. Aedeagus with shaft curved strongly dorsad and tapering, the terminal part with a short, ventrally directed 

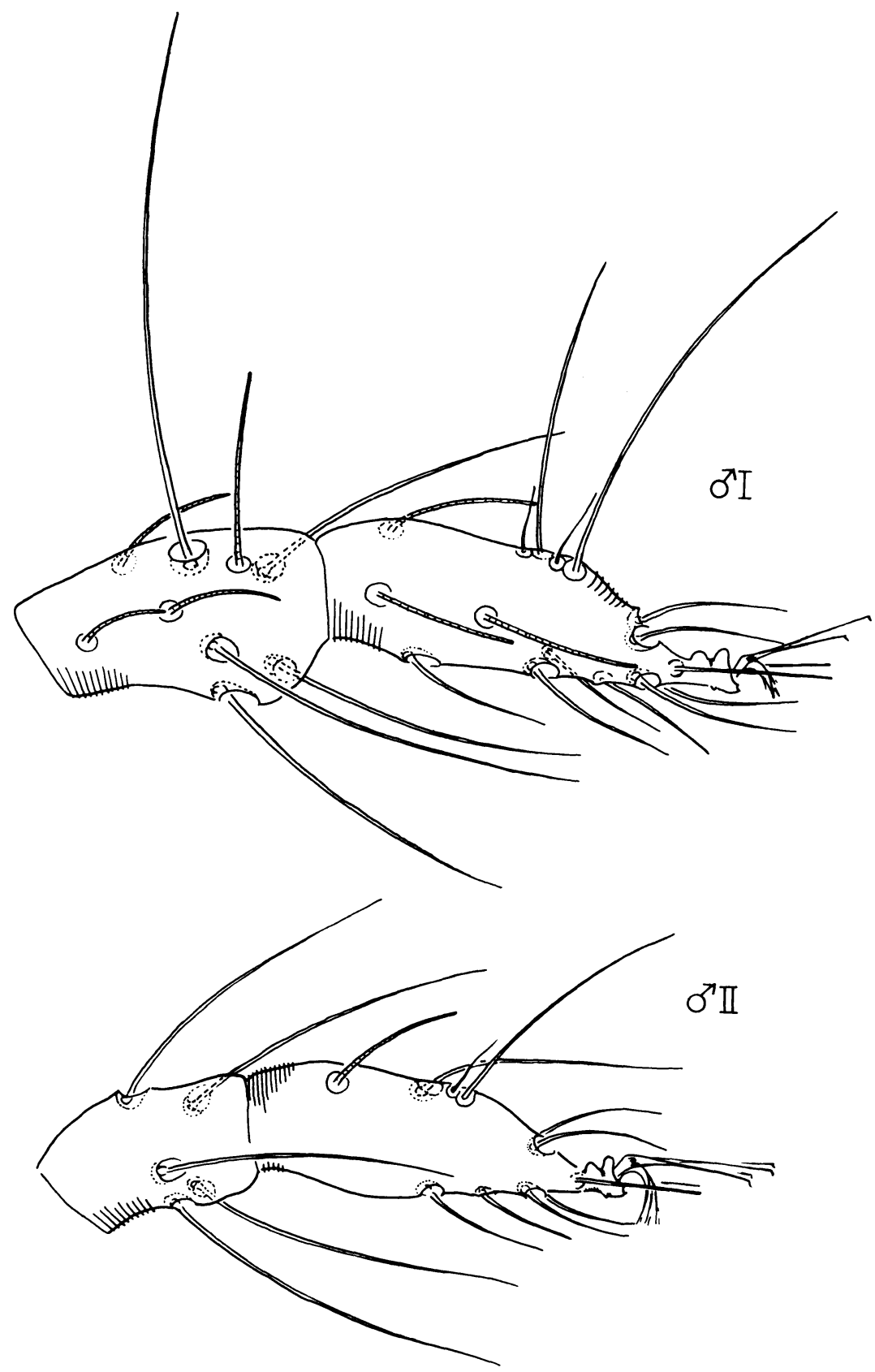

Fig. 14. Eotetranychus ancora: tibia and tarsus I of male and tibia and tarsus II of male. 
angulation, the termination slender and acute. Length of body $255 \mu$; greatest width of body $89 \mu$.

Female. Palpus with terminal sensillum strong, longer than broad. Tibia I with nine tactile and one sensory setae; tarsus I with five tactile and one sensory setae proximal to duplexes. Tibia II with seven tactile setae; tarsus II with four tactile and one sensory setae proximal to duplex setae. Hysterosoma with transverse striae between third pair of dorsocentrals. Length of body $357 \mu$; greatest width of body $165 \mu$.
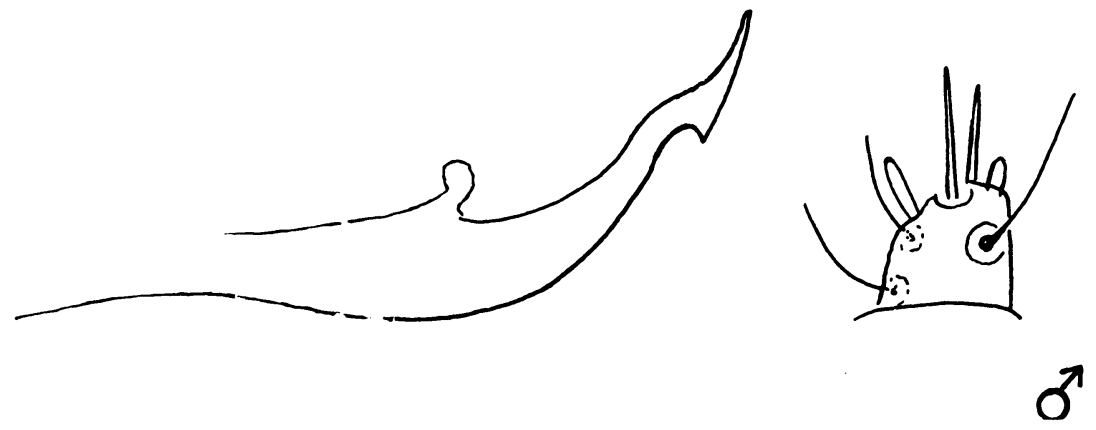

Fig. 15. Eotetranychus ancora: aedeagus and terminal segment of palpus of male.

Holotype. Male, Barkly, Mauritius, June, 1955 (L. A. Moutia), on apple; in the British Museum (Natural History).

Paratypes. Two males, 4 females, Barkly, Mauritius, June, 1955 (L. A. Moutia), on apple.

\section{Eotetranychus cernuus, new species}

(Figs. 16, 17, 18)

The aedeagus of Eotetranychus cernuus resembles that of $E$. perplexus (McGregor) (western United States) in that the distal part bears an anteroventral angulation. The shaft of the aedeagus, however, is long and slender.

Male. Palpus with terminal sensillum tiny and conical. Peritreme terminating in a simple bulb. Tibia I with nine tactile and four sensory setae; tarsus I with four tactile and three sensory setae proximal to duplexes; empodium I with the middle pair of hairs very strong, and the dorsal and ventral pairs very weak. Tibia II with seven tactile setae. Idiosoma with dorsal setae long and slender, tapering. Aedeagus with shaft slender, nearly straight; distal part bent ventrad, with a small anteroventrally directed angulation and the end acutely tapering. Length of body $255 \mu$; greatest width of body $114 \mu$.

Female. Palpus with terminal sensillum strong, about twice as long as broad. Tibia I with nine tactile and one sensory setae; tarsus I with four tactile and one sensory setae proximal to duplexes. Tibia II with eight 


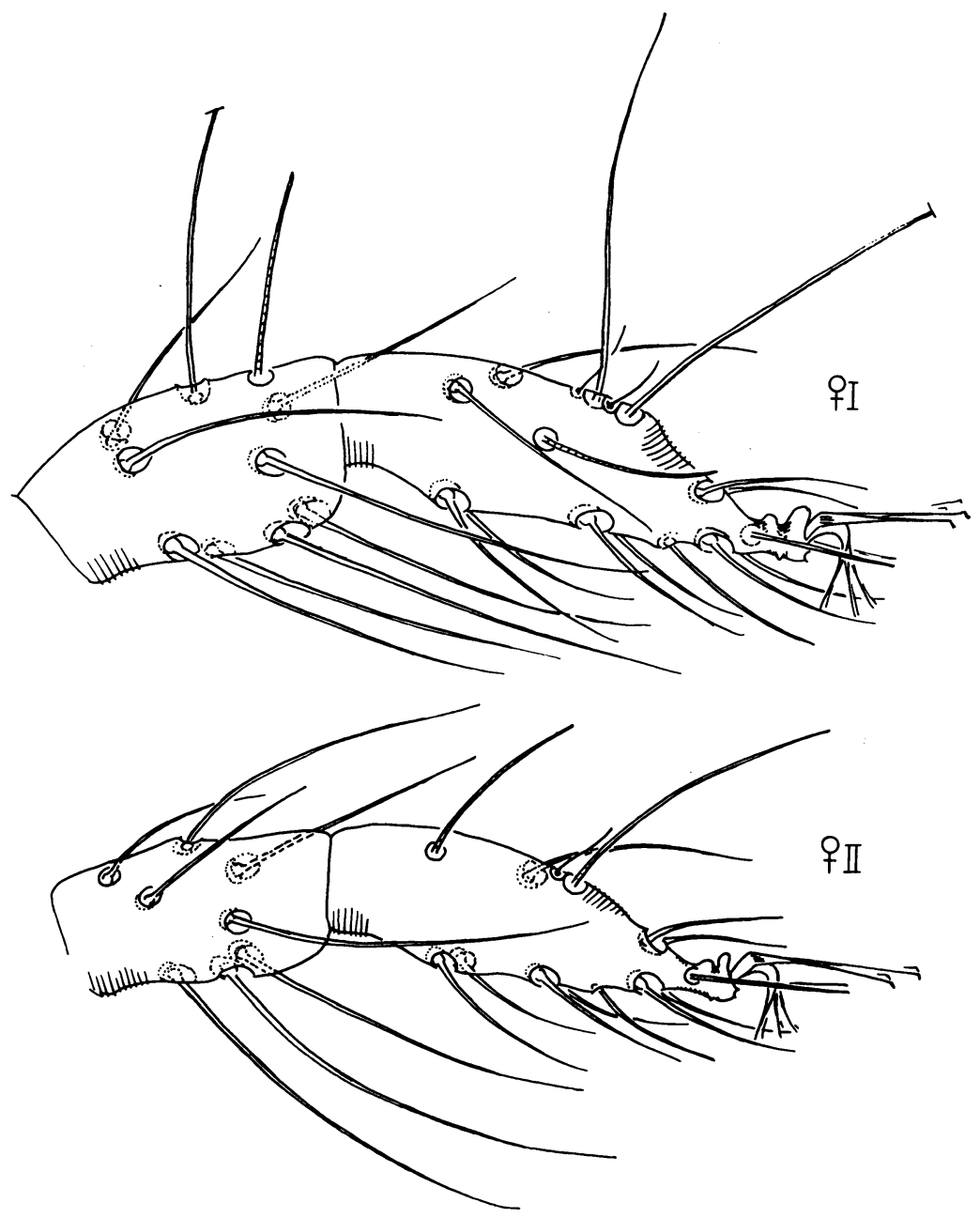

Fig. 16. Eotetranychus cernuus : tibia and tarsus I of female and tibia and tarsus II of female.

tactile setae. Hysterosoma with transverse striae between third pair of dorsocentrals. Length of body $382 \mu$; greatest width of body $178 \mu$.

Holotype. Female, Lake Albert, Kysenyi, Belgian Congo, May 3, 1955 (E. W. Baker), on Annona chrysophylla; type no. 2492 in the U. S. National Museum.

Paratypes. Twenty-one males, 50 females, Kysenyi, Lake Albert, Belgian Congo, May 3, 1955 (E. W. Baker), on Annona chrysophylla. 


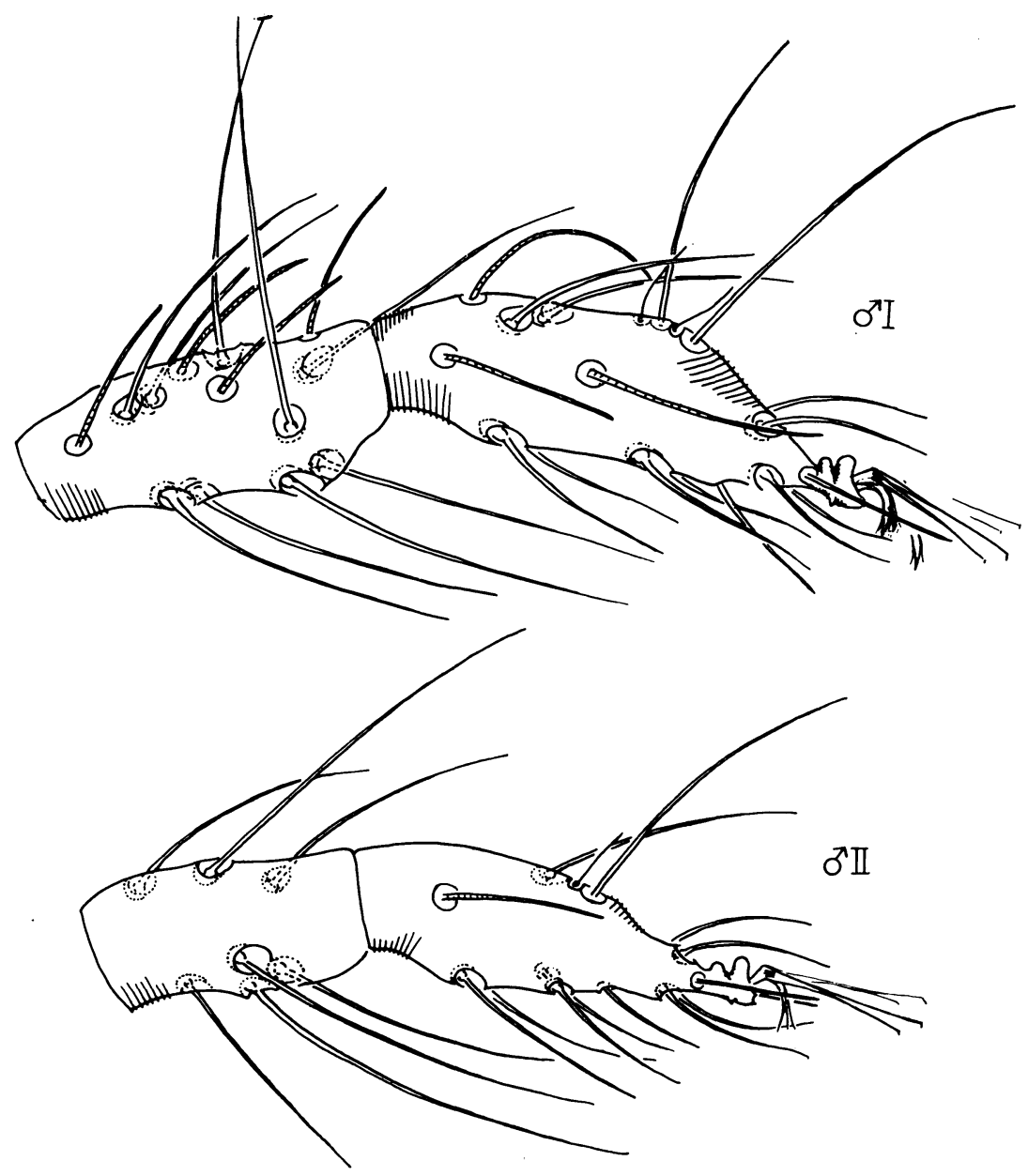

Fig. 17. Eotetranychus cernuus: tibia and tarsus I of male and tibia and tarsus II of male.

\section{Eotetranychus cyphus, new species}

(Figs. 19, 20, 21)

The aedeagus of cyphus differs from those of other species of Eotetranychus having the distal part deflexed and sigmoid in that the external shaft is thick and curves strongly dorsad from the base.

Male. Palpus with terminal sensillum minute. Peritreme with a terminal hook. Tibia I with nine tactile and four sensory setae; tarsus I with four tactile and three sensory setae proximal to duplexes; empodium I with middle pair of hairs strong, the dorsal and ventral pairs of hairs very weak. Tibia Il with eight tactile setae. Idiosoma with dorsal setae long, slender, 

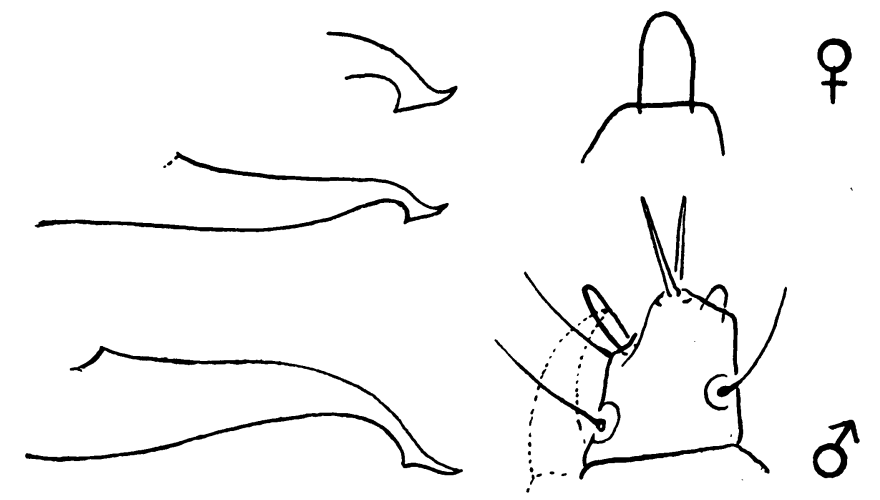

Fig. 18. Eotetranychus cernuus: aedeagus, terminal sensillum of female palpus, and terminal segment of male palpus.
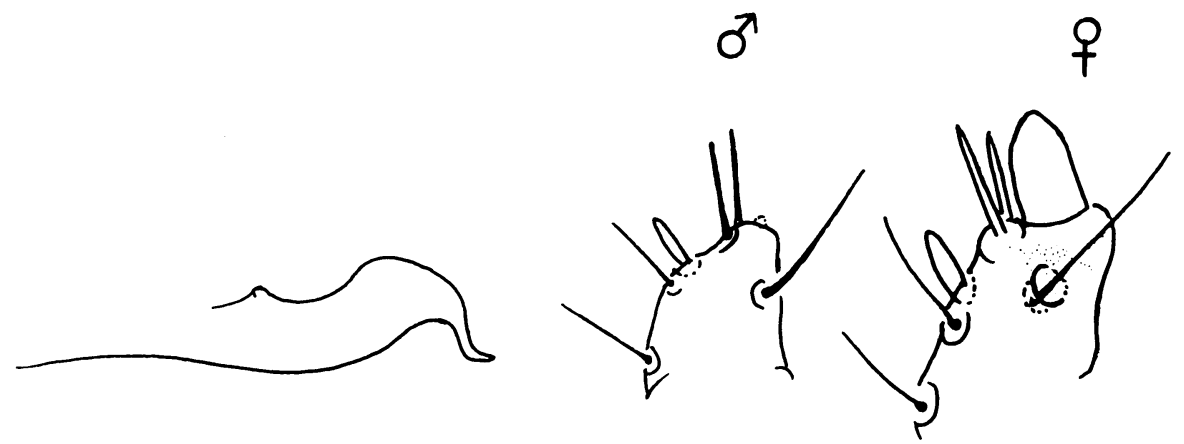

Fig. 19. Eotetranychus cyphus: aedeagus and terminal segment of palpus of male and female.

and tapering. Aedeagus with shaft short and broad, curving strongly distad from base, the distal part deflexed and sigmoid, narrowly tapering to a blunt point. Length of body $268 \mu$; greatest width of body $127 \mu$.

Female. Palpus with terminal sensillum strong, about twice as long as broad. Tibia I with eight tactile and one sensory setae; tarsus I with five tactile and one sensory setae proximal to duplexes. Tibia II with eight tactile setae. Hysterosoma with transverse striae between third pair of dorsocentrals. Length of body $331 \mu$; greatest width of body $178 \mu$.

Holotype. Male, Stanleyville, Belgian Congo, April 18, 1955 (E. W. Baker), on ?Bixa; type no. 2493 in the U. S. National Museum.

Paratypes. Nine males, 21 females, Stanleyville, Belgian Congo, April 18, 1955 (E. W. Baker), on ?Bixa. 


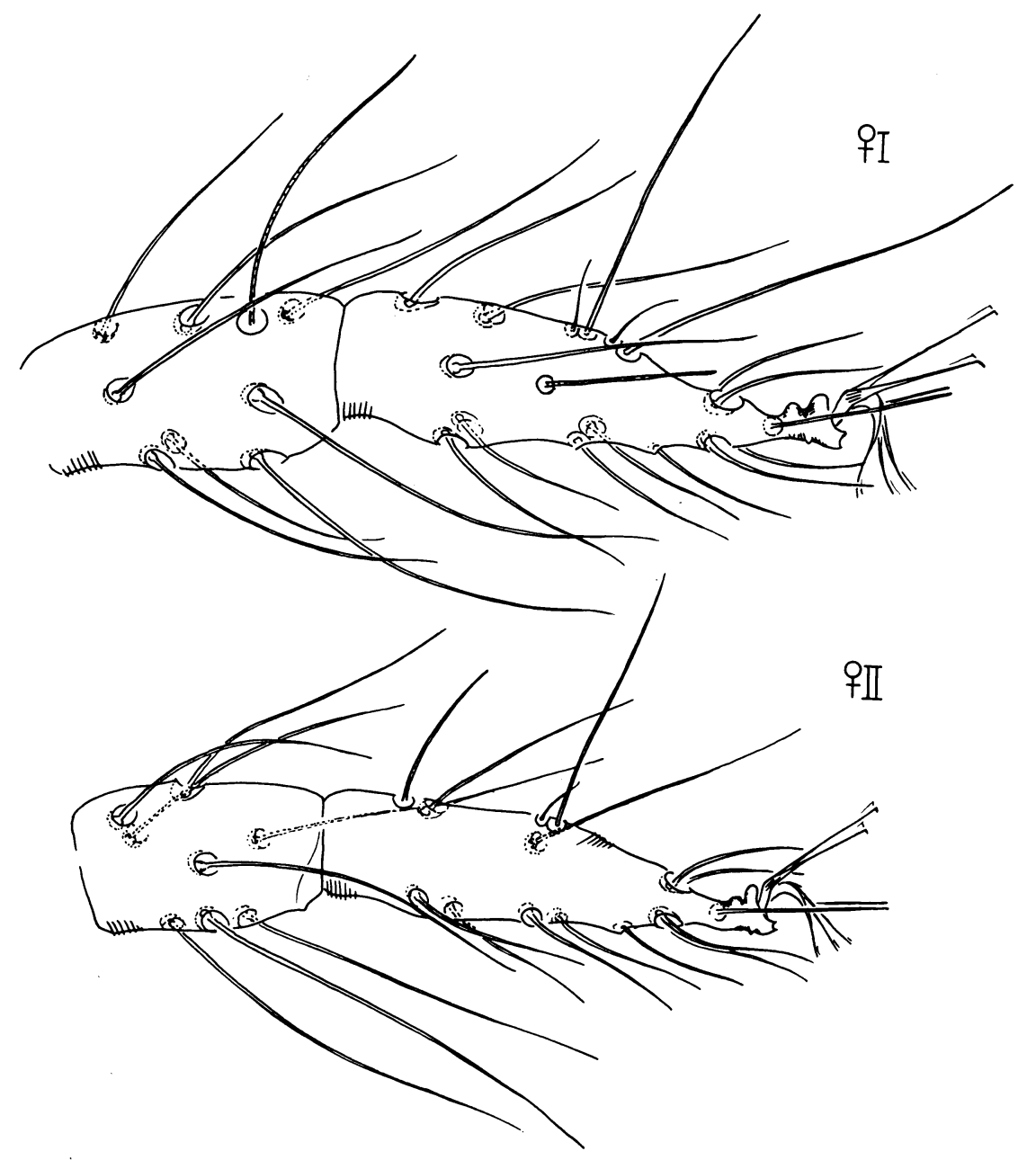

Fig. 20. Eotetranychus cyphus: femur and tarsus I of female and femur and tarsus II of female. 


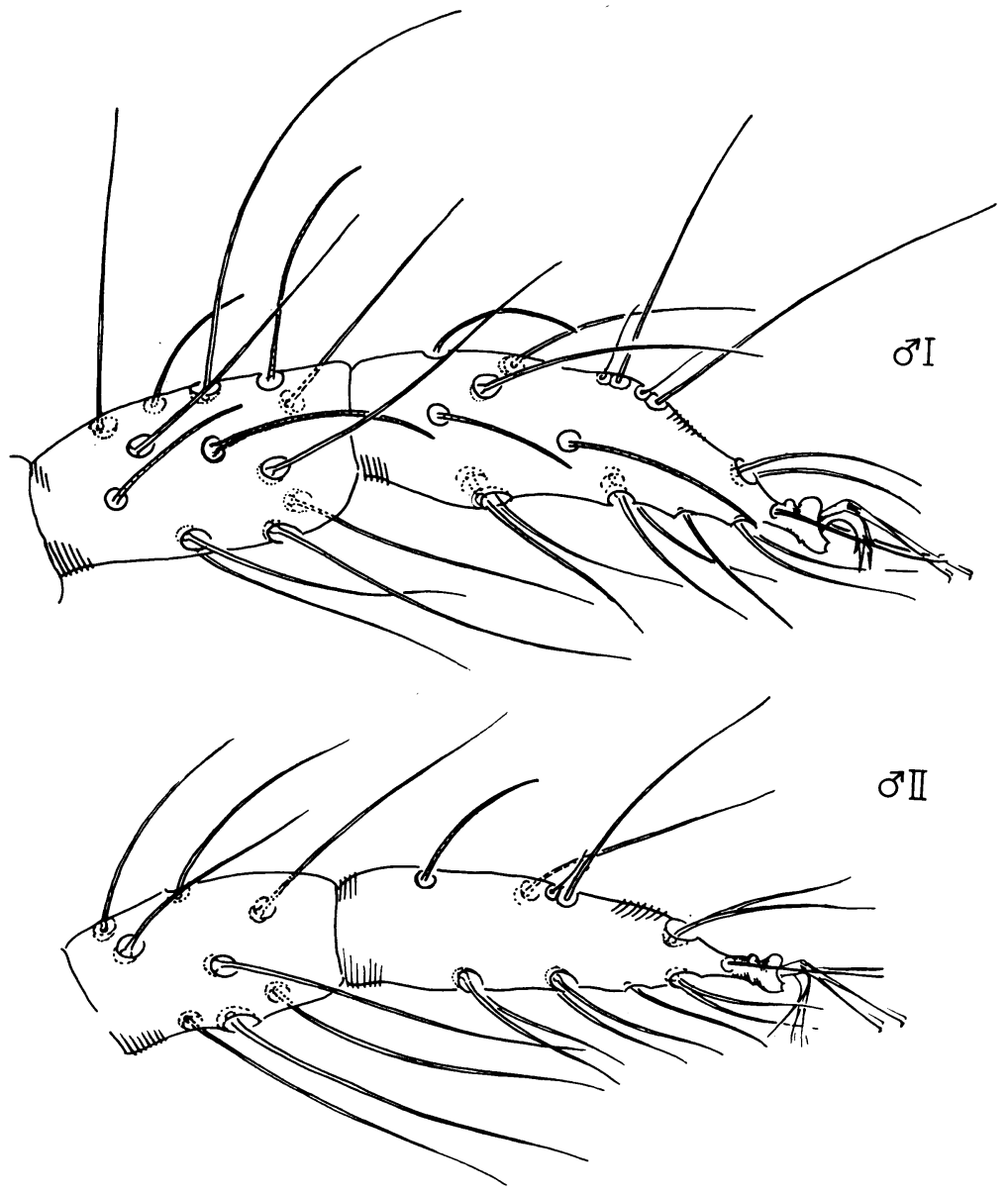

Fig. 21. Eotetranychus cyphus: tibia and tarsus I of male and tibia and tarsus II of male. 


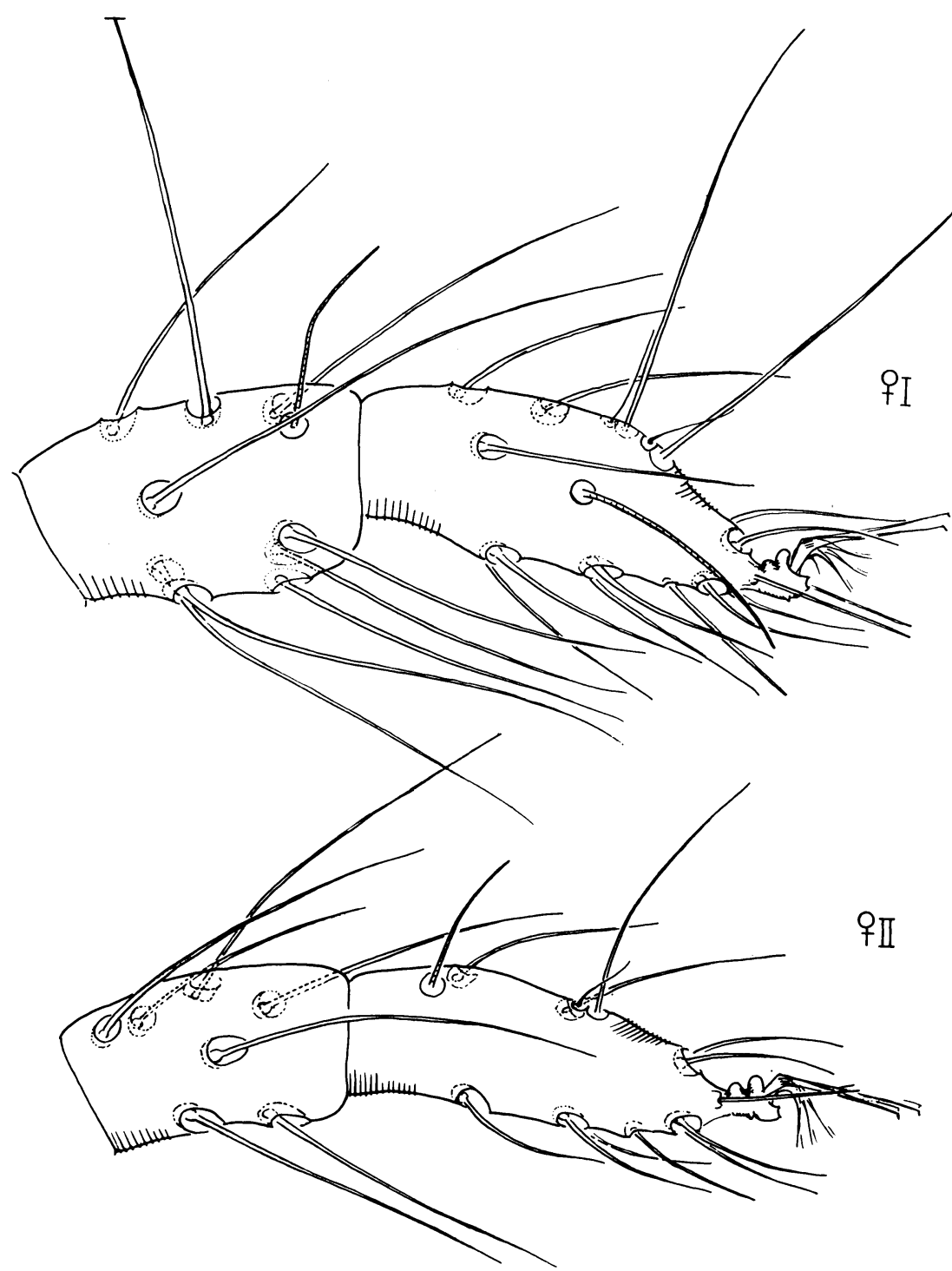

Fig. 22. Eotetranychus cybebus: tibia and tarsus I of female and tibia and tarsus II of female.

\section{Eotetranychus cybebus, new species}

(Figs. 22, 23, 24)

The aedeagus of Eotetranychus cybebus is similar to that of $E$. deflexus (McGregor) (United States), but the shaft is slender with the ventral margin nearly straight. 


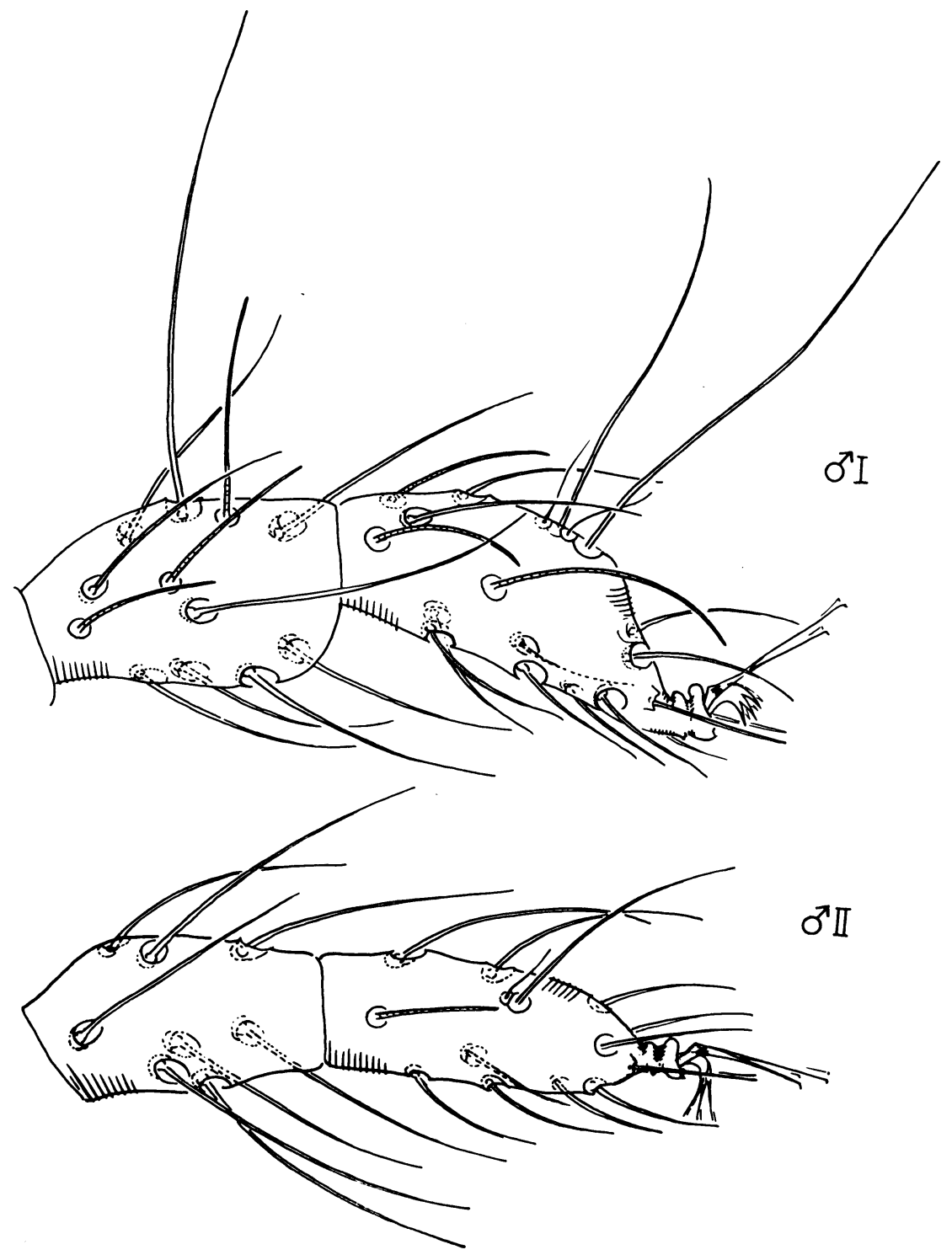

Fig. 23. Eotetranychus cybebus: tibia and tarsus I of male and tibia and tarsus II of male.

Male. Palpus with terminal sensillum very small. Peritreme terminating in a simple bulb. Tibia I with nine tactile and three sensory setae; tarsus I with four tactile and three sensory setae proximal to duplex setae; empodium I bifid with each side strongly tridigitate. Tibia II with eight tactile setae. Idiosoma with dorsal setae long and slender, tapering. Aedeagus with 
shaft long and straight, narrowing slightly before the deflexed, sigmoid distal part. Length of body $293 \mu$.

Female. Palpus with terminal sensillum large, about twice as long as broad. Tibia I with nine tactile and one sensory setae; tarsus I with five tactile and one sensory setae proximal to duplexes. Tibia II with seven tactile setae; tarsus II with three tactile and one sensory setae proximal to duplex setae. Hysterosoma with transverse striae between third pair of dorsocentrals. Length of body $360 \mu$; greatest width of body $165 \mu$.

Holotype. Male. Nioka, Belgian Congo, May 2, 1955 (E. W. Baker), on Vernonia sp.; type no. 2494 in the U. S. National Museum.

Paratypes. Two males, 35 females, Nioka, Belgian Congo, May 2, 1955 (E. W. Baker), on Vernonia sp.
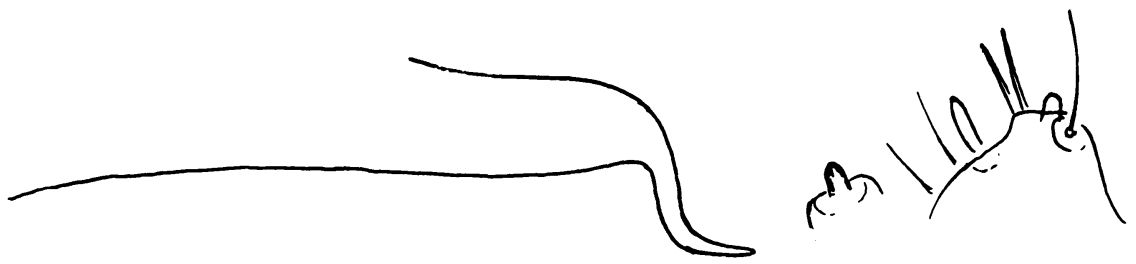

Fig. 24. Eotetranychus cybebus: aedeagus and termination of palpus of male.

\section{GENUS SCHIZOTETRANYCHUS TRÄGÅRDH, 1915}

Schizotetranychus Trägårdh, 1915, Stockholm Landtbr.-Akad. Handl. 54: 277.

Schizotetranychus is very closely allied to the genus Eotetranychus, differing only in the empodium. The proximal pair of empodial hairs is strongly developed to resemble a bifid claw, and the dorsal two pairs of empodial hairs are minute or absent. The proximoventral chaeta is variously developed.

This genus has not been known previously from Africa. Five new species are here described. They are all closely allied, having the dorsal setae of the body awl-shaped and moderately short.

\section{Key to Species: Females}

1. Propodosoma with dorsal integument bearing a reticulate pattern

(1) reticulatus

- Propodosoma with dorsal integument bearing longitudinal striae... 2 2

2. Hysterosoma with inner sacral setae much more widely spaced than second pair of dorsocentral setae. . . . . . . . . . . . . . 3

- Hysterosoma with inner sacral setae about as wide apart as second pair of dorsocentral setae.................. 4 
3. Hysterosoma with transverse striae between first and second pairs of dorsocentral setae........................ (2) spiculus

- Hysterosoma with longitudinal striae between first and third pairs

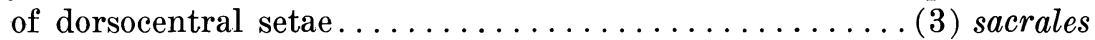

4. Stylophore convex mediodistally................... (4) gausus

- Stylophore edentate mediodistally............... (5) rhodanus

\section{Schizotetranychus reticulatus, new species}

(Figs. 25 to 29 )

The female and deutonymph of reticulatus differ from all known species of Schizotetranychus by the reticulations on the propodosoma. The male resembles S. spireafolia Garman (northeastern United States) in having the dorsal setae of the body minutely serrate and tapering from a broadened
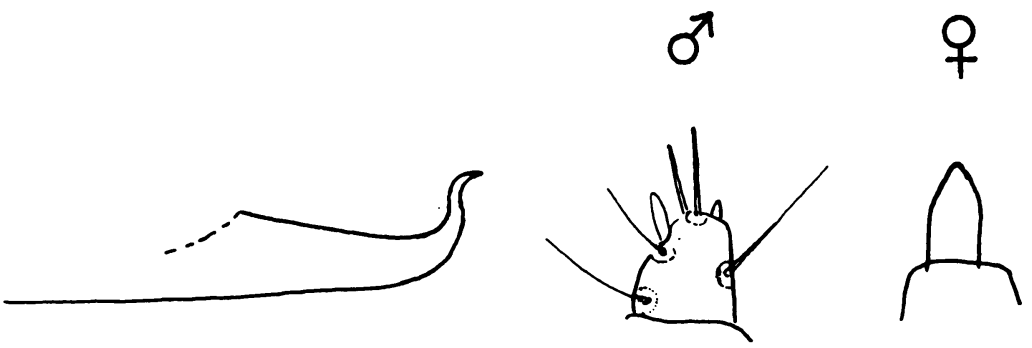

Fig. 25. Schizotetranychus reticulatus: aedeagus, terminal segment of male palpus, and terminal sensillum of female palpus.

base and in having the aedeagus with the distal part abruptly bent dorsad and evenly sigmoid. However, the aedeagus is bent slightly dorsocaudad rather than slightly dorsocephalad.

Male. Palpus with terminal sensillum tiny. Stylophore evenly rounded distally. Peritreme hooked distally. Tibia I with nine tactile and four sensory setae; tarsus I with two tactile and three sensory setae proximal to duplexes; tibia II with five tactile setae; empodium with a fine hair above each clawlike member and a fine proximoventral hair. Dorsal integument with smooth striae, those on the propodosoma and laterally on the metapodosoma longitudinal, those on the rest of the hysterosoma transverse. Idiosoma with dorsal setae awl-shaped and finely serrate; second dorsal propodosomals the longest, the other dorsal setae shortening caudally ; dorsocentral hysterosomals equal to longitudinal distances between them; inner sacrals much more widely spaced than second dorsocentrals. Aedeagus with shaft gradually narrowing, the distal part curved dorsad, sigmoid and tapering. Length of body $287 \mu$; greatest width of body $114 \mu$.

Female. Palpus with terminal sensillum twice as long as broad. Tibia I with nine tactile and one sensory setae; tarsus I with two tactile and one sensory setae proximal to duplexes; tibia II with five tactile setae. Propodo- 


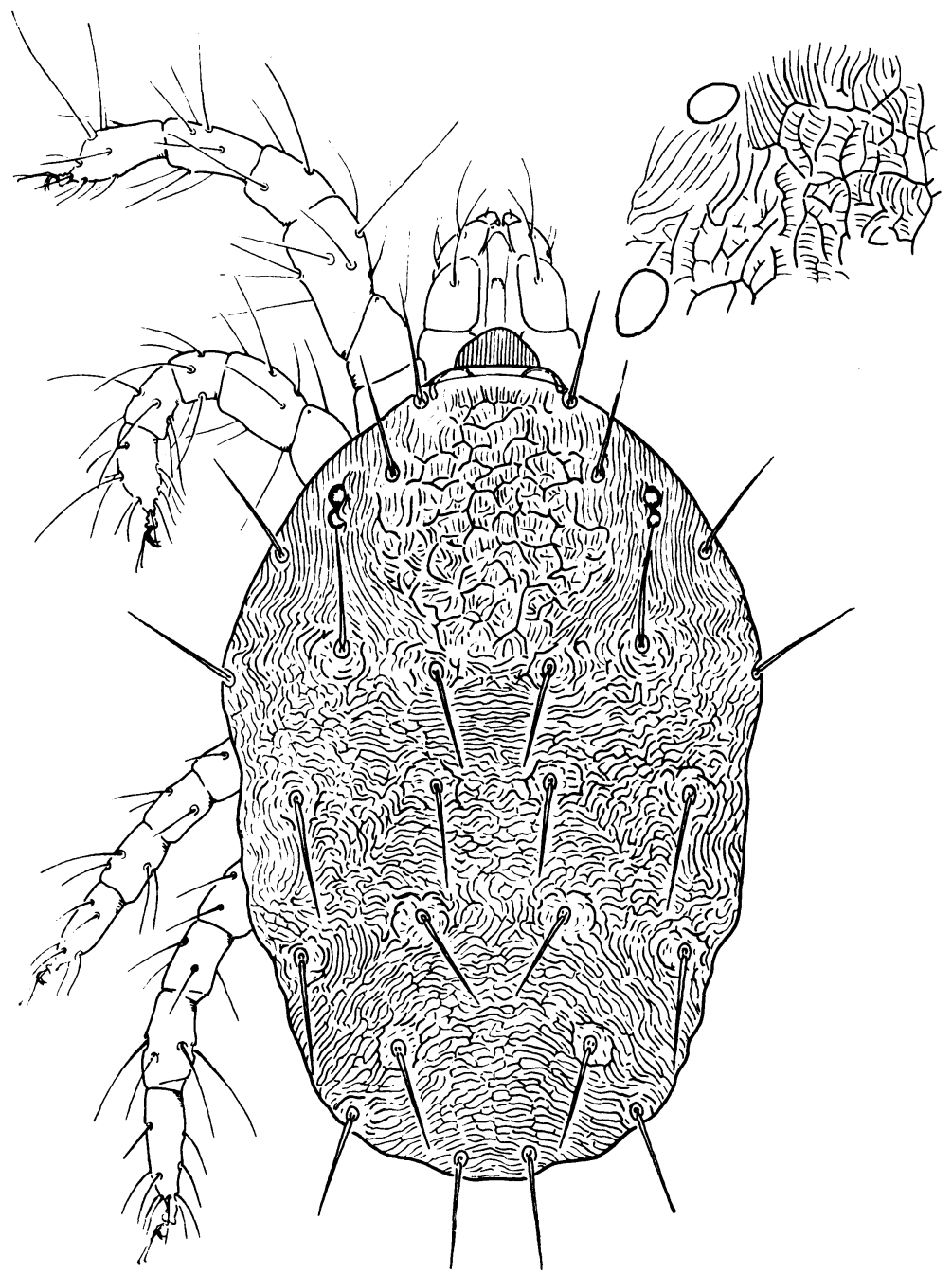

Fig. 26. Schizotetranychus reticulatus: dorsal aspect of female with enlargement of mediodorsal area of propodosomal integument.

soma with mediodorsal area reticulate, the reticulations bearing irregular striae, and lateral area with longitudinal striae; hysterosoma with striae mostly transverse along mediodorsum and irregular between mediodorsals and laterally (varying to being nearly all irregular). Dorsal setae of idiosoma awl-shaped, nearly nude, of approximately same length except for slightly shorter dorsocentral hysterosomals and inner sacrals, the former 


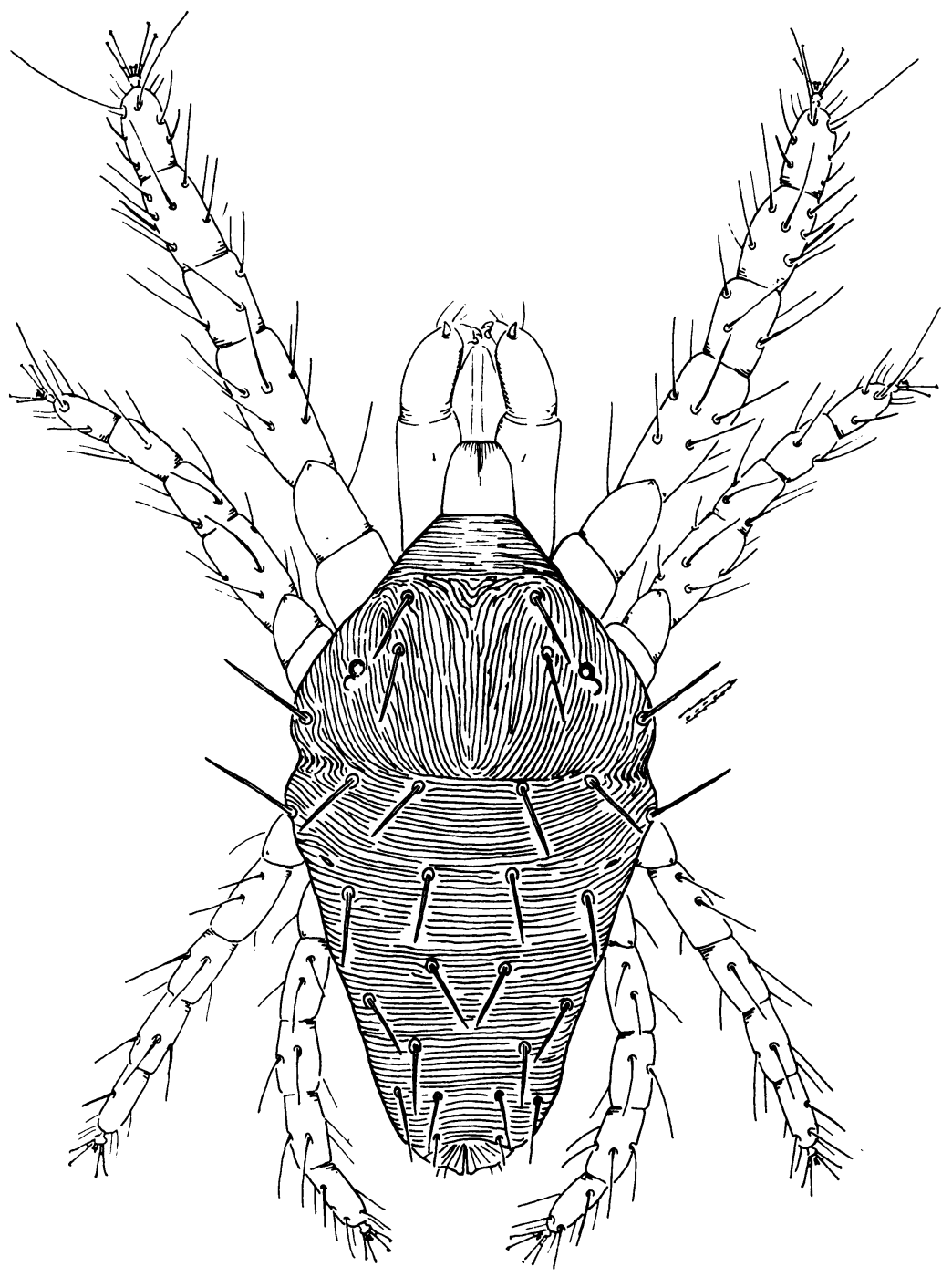

Fig. 27. Schizotetranychus reticulatus: dorsal aspect of male.

slightly shorter than distances between pairs. Length of body $319 \mu$; greatest width of body $153 \mu$.

Holotype. Male, Ruindi Camp, Belgian Congo, May 11, 1955 (E. W. Baker), on Grewia sp.; type no. 2495 in the U. S. National Museum.

Paratypes. Twenty-three males, 46 females, Ruindi Camp, Belgian Congo, May 11, 1955 (E. W. Baker), on Grewia sp. 

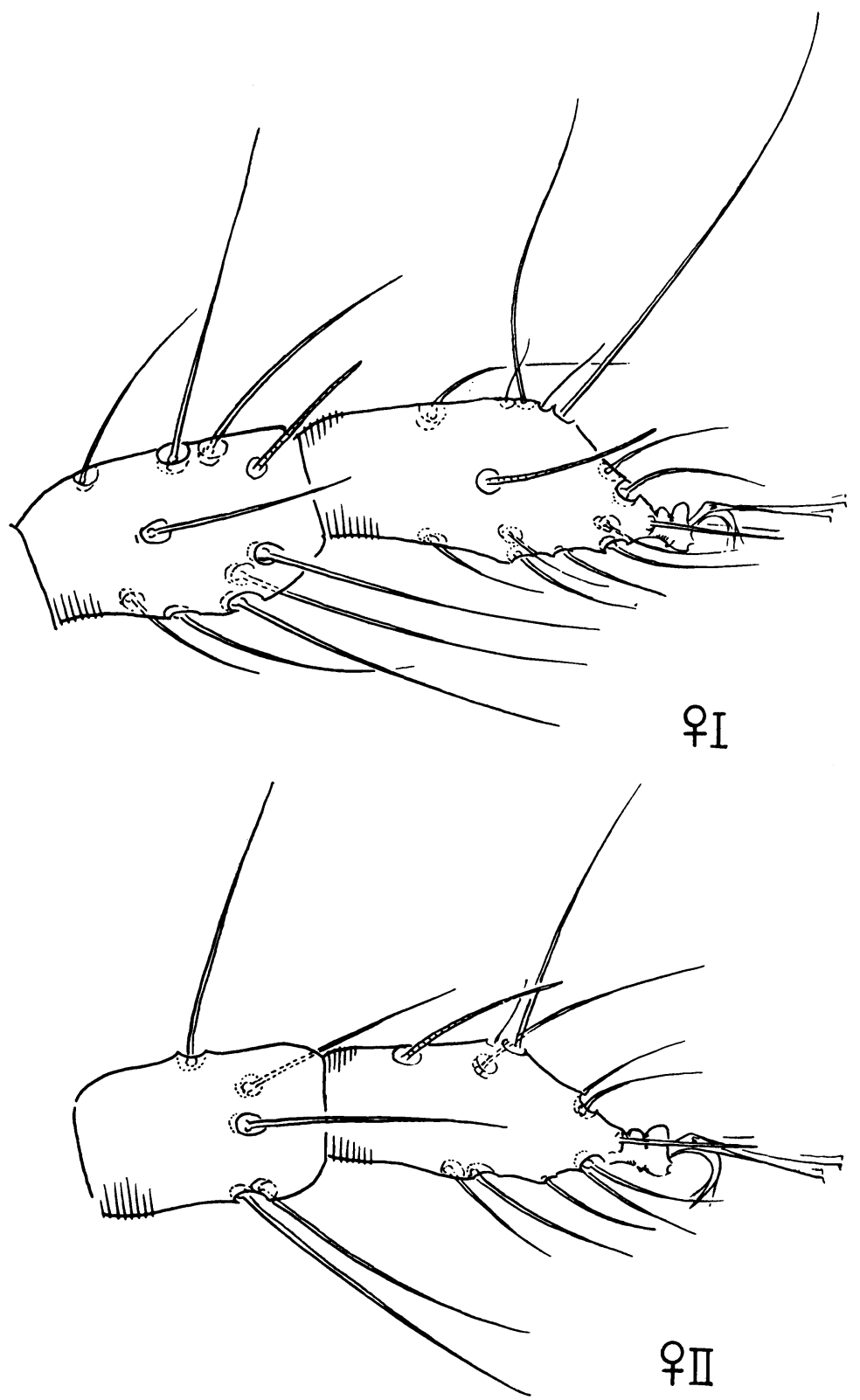

Fig. 28. Schizotetranychus reticulatus: tibia and tarsus I of female and tibia and tarsus II of female. 


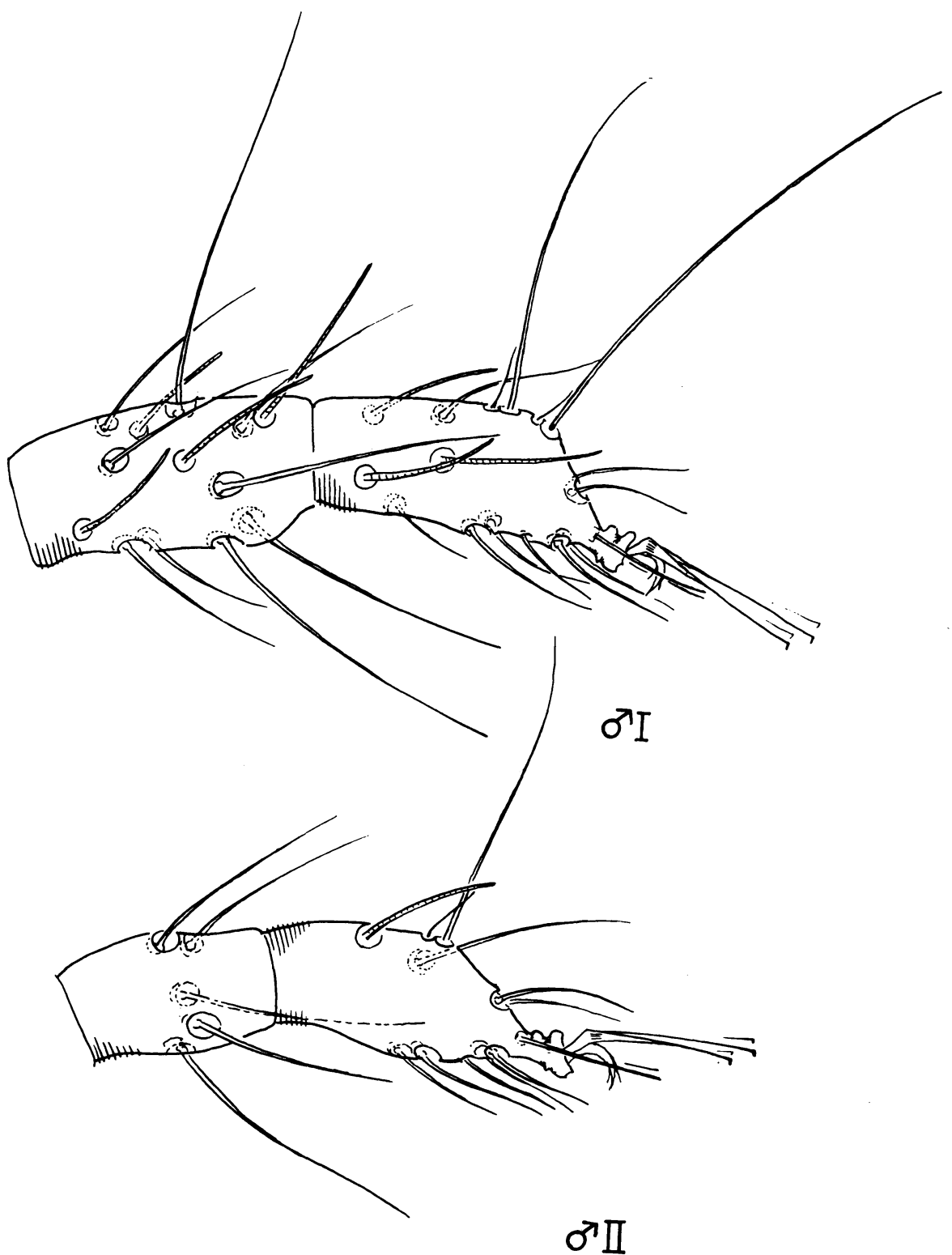

Fig. 29. Schizotetranychus reticulatus: tibia and tarsus I of male and tibia and tarsus II of male. 


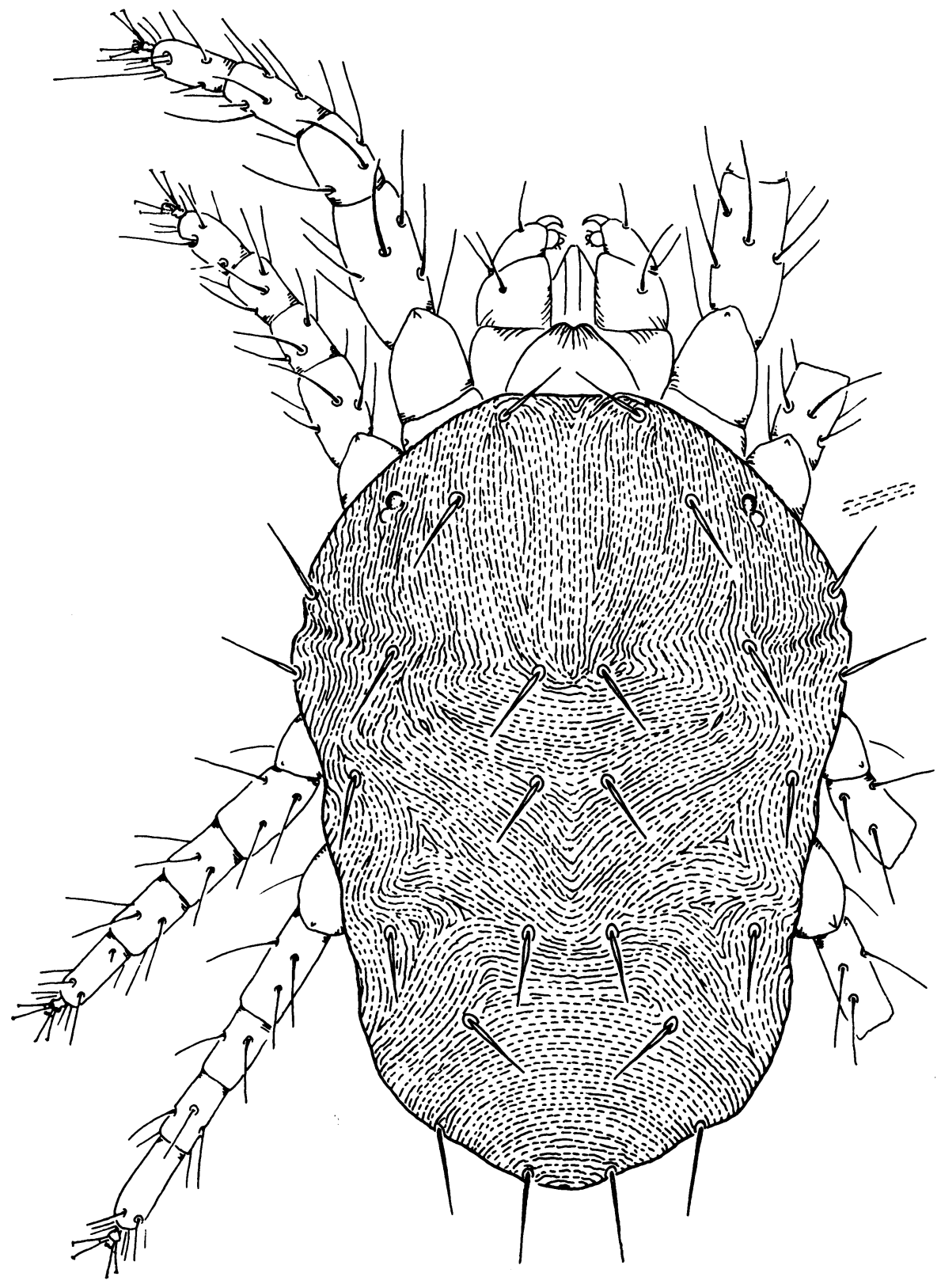

Fig. 30. Schizotetranychus spiculus: dorsal aspect of female. 


\section{Schizotetranychus spiculus, new species}

(Figs. 30, 31, 32)

The female of Schizotetranychus spiculus closely resembles that of S. hindustanicus (Hirst) (India) in that the dorsocentral hysterosomals are widened near the base, acutely tapering, and shorter than the longitudinal intervals between them, and the caudal setae of the hysterosoma are longer and more filiform and serrate. S. spiculus differs, however, in that the dorsocentral hysterosomals are only one half rather than two thirds the length of the longitudinal intervals between them, and the striae along the middorsal line between the second and third pairs of dorsocentral hysterosomals are rather longitudinally parallel. The male is unknown.

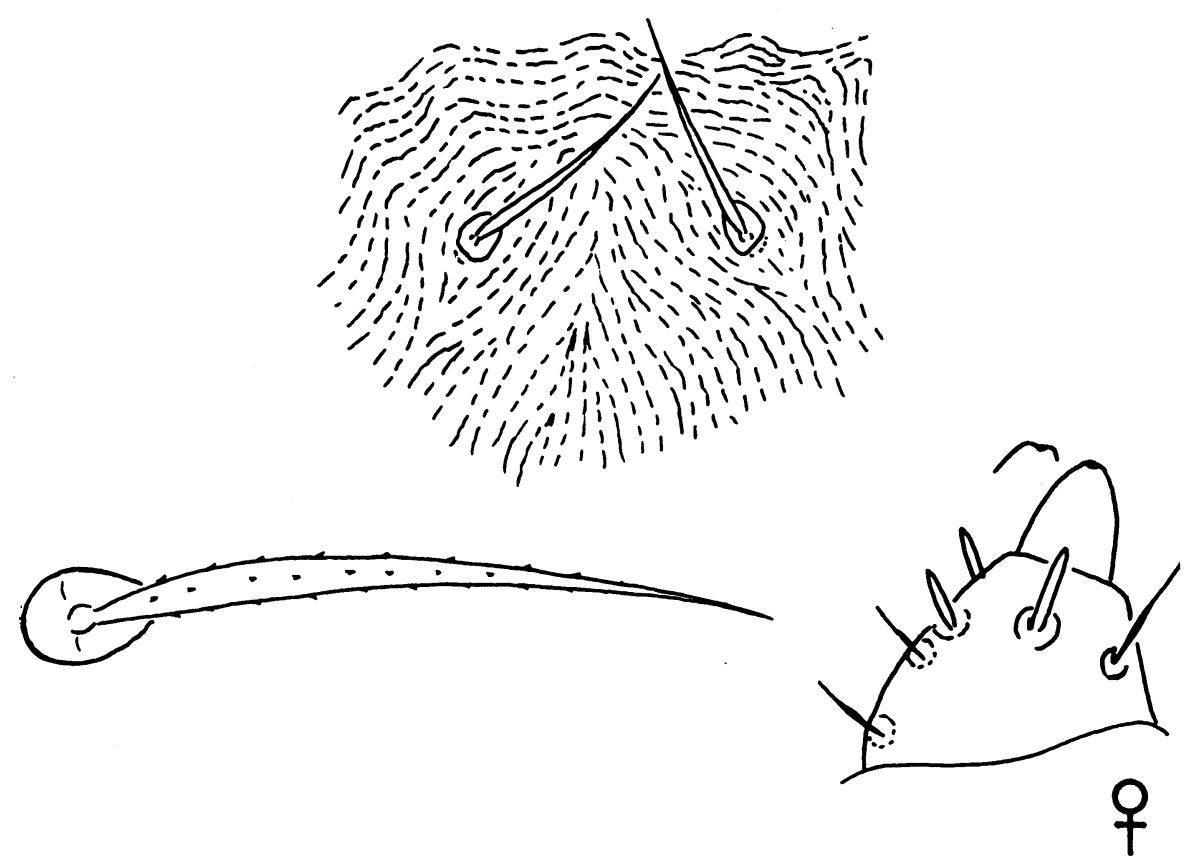

Fig. 31. Schizotetranychus spiculus: dorsal integument between third pair of dorsocentral hysterosomals of female, dorsal seta of idiosoma of female, and terminal segment of palpus of female.

Female. Palpus with terminal sensillum one and one half times as long as broad and slightly edentate at apex. Stylophore edentate anteriorly. Peritreme hooked distally. Tibia I with seven tactile and one sensory setae; tarsus I with two tactile and one sensory setae proximal to duplexes; tibia II with five tactile setae; empodium with each clawlike member sharply bent and bearing a very weak dorsal hair and a proximoventral chaeta. Dorsal integument finely striate, the striae with small, elongate lobes; propodosoma with striae longitudinal; hysterosoma with striae transverse except for longitudinal striae medially between second and third pairs of dorsocentrals. First and second dorsal propodosomals, dorsocentral and dorsolateral 


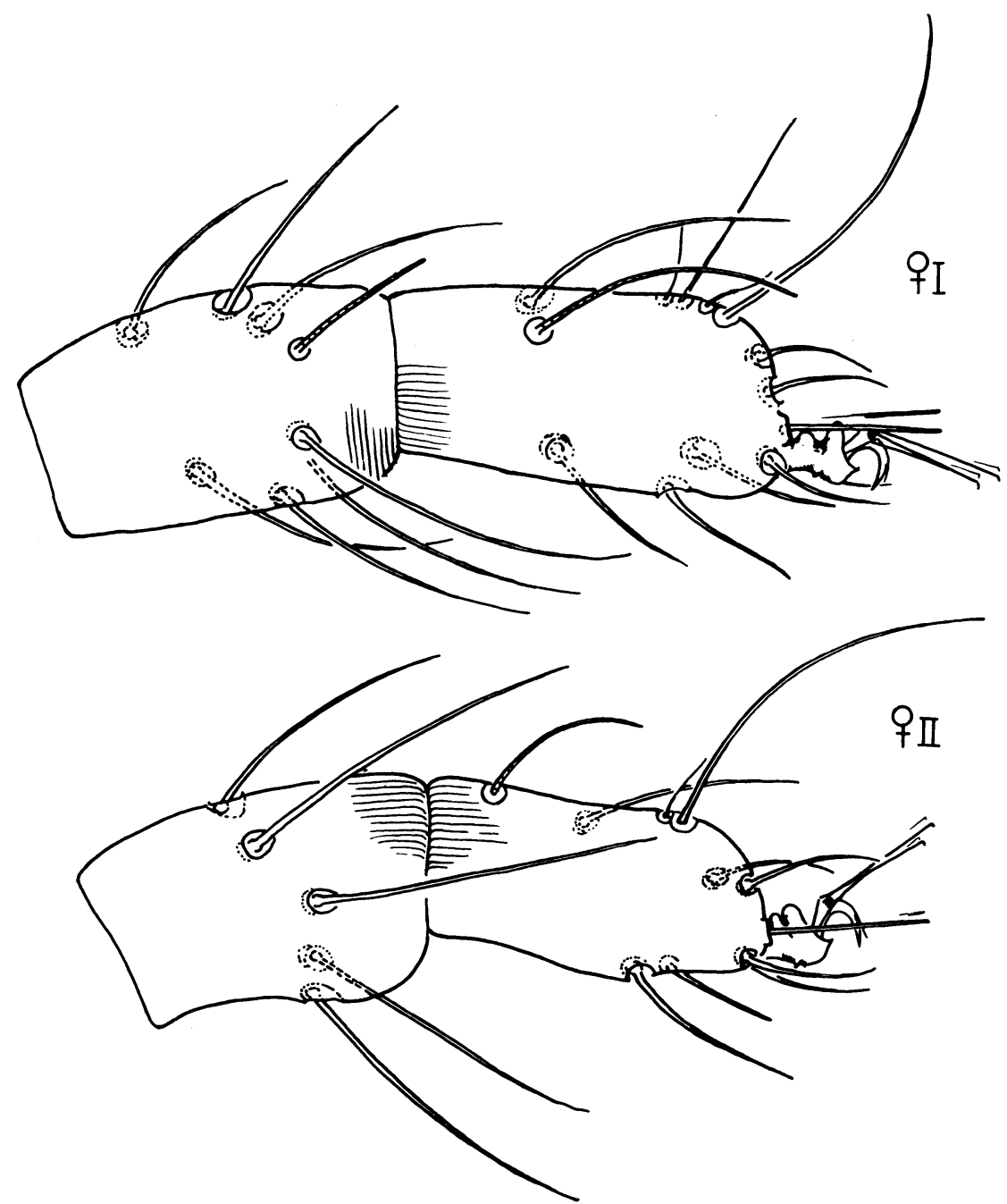

Fig. 32. Schizotetranychus spiculus: tibia and tarsus I of female and tibia and tarsus II of female.

hysterosomals, and inner sacrals awl-shaped and nearly nude, the dorsocentral hysterosomals slightly less than one half as long as distances between them longitudinally; third dorsal propodosomal, humeral, outer sacrals, and clunals longer than the oblate setae, slender, and serrate; outer sacrals spaced much more widely apart than second dorsocentrals. Length of body $382 \mu$; greatest width of body $240 \mu$.

Holotype. Female, Kaloleni, Kenya, August, 1955 (P. E. Wheatly), on citrus; in the British Museum (Natural History).

Paratypes. Three females, Kaloleni, Kenya, August, 1955 (P. E. Wheatly), on citrus. 


\section{Schizotetranychus sacrales, new species}

(Figs. 33, 34)

The female of Schizotetranychus sacrales closely resembles that of $S$. spiculus except that the hysterosoma bears longitudinal striae between the first pair of dorsocentral setae and the stylophore is not cleft.

Female. Palpus with terminal sensillum stout. Stylophore evenly convex distally. Peritreme hooked distally. Tibia I with seven tactile and one sensory setae; tarsus I with two tactile and one sensory setae proximal to duplexes; tibia II with five tactile setae; empodium with each clawlike member sharply

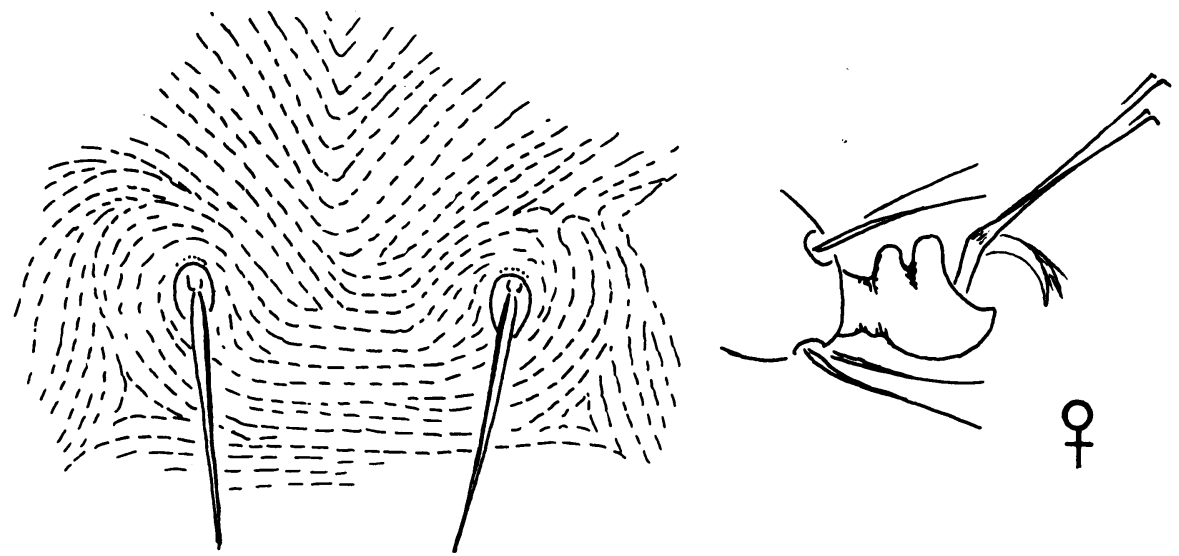

Fig. 33. Schizotetranychus sacrales : dorsal integument between third pair of dorsocentral hysterosomals of female and empodium of female.

bent and bearing a very weak dorsal hair and a proximoventral chaeta. Dorsal integument of idiosoma finely striate, the striae with small, elongate lobes; propodosoma with striae longitudinal; hysterosoma with striae transverse except for longitudinal striae between each of the three pairs of dorsocentrals. First and third pairs of dorsal propodosomals slender and pointed, the first nearly one half as long as interval between them; second dorsal propodosomal, dorsocentral and dorsolateral hysterosomals, and inner sacrals awl-shaped, the dorsocentral hysterosomals about one half as long as distances between them longitudinally ; humeral, outer sacrals, and clunals slender and serrate, longer than the oblate setae; outer sacrals spaced much more widely apart than second dorsocentrals. Length of body $370 \mu$; greatest width of body $190 \mu$.

Male. Dorsal chaetotaxy similar to female. Length of body $325 \mu$; greatest width of body $190 \mu$.

Holotype. Female, Butembo, Belgian Congo, May 8, 1955 (E. W. Baker), on papilionaceous vine; type no. 2509 in the U. S. National Museum.

Paratypes. One male, 1 female, Butembo, Belgian Congo, May 8, 1955 (E. W. Baker), on a papilionaceous plant. 


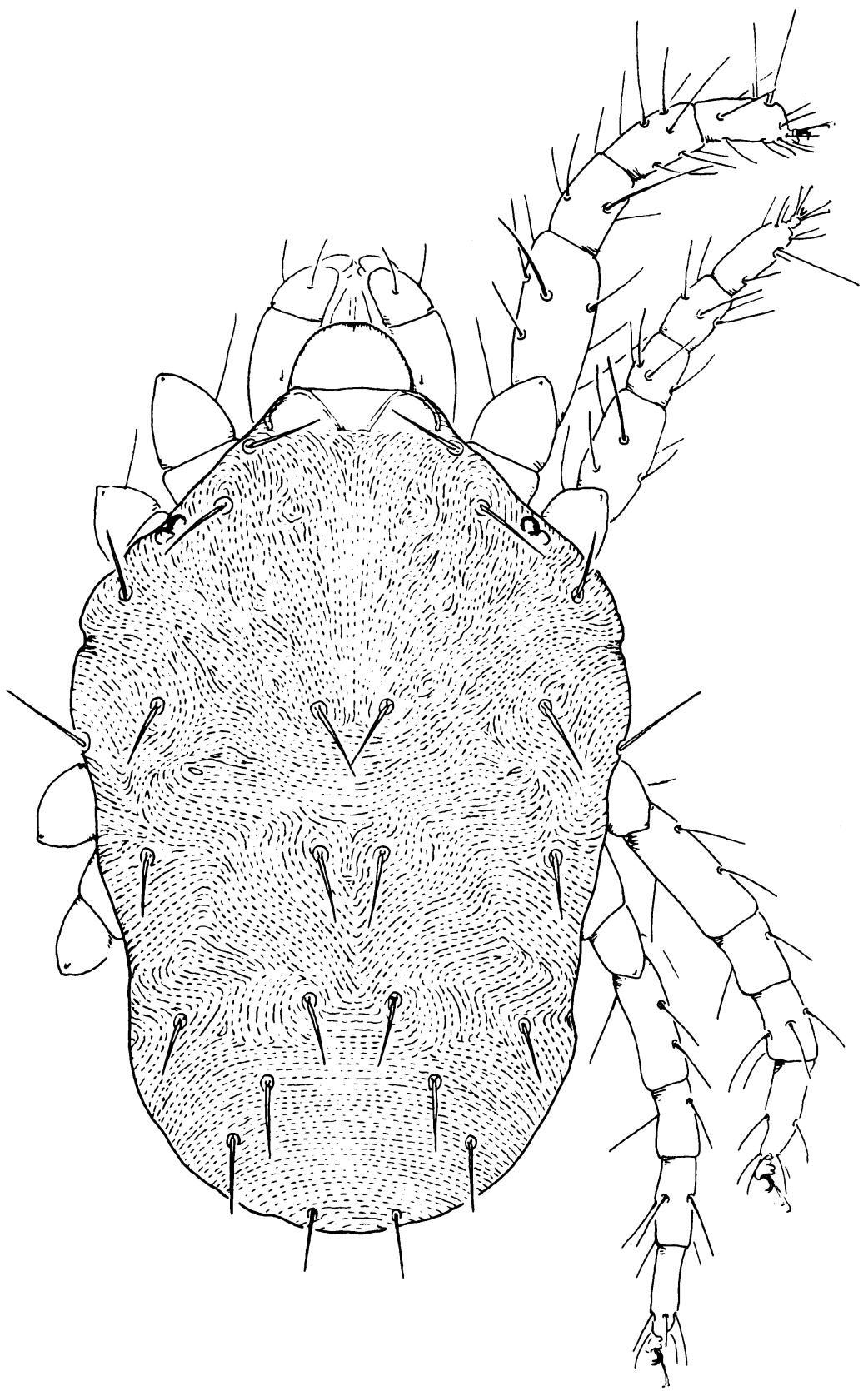

Fig. 34. Schizotetranychus sacrales: dorsal aspect of female. 


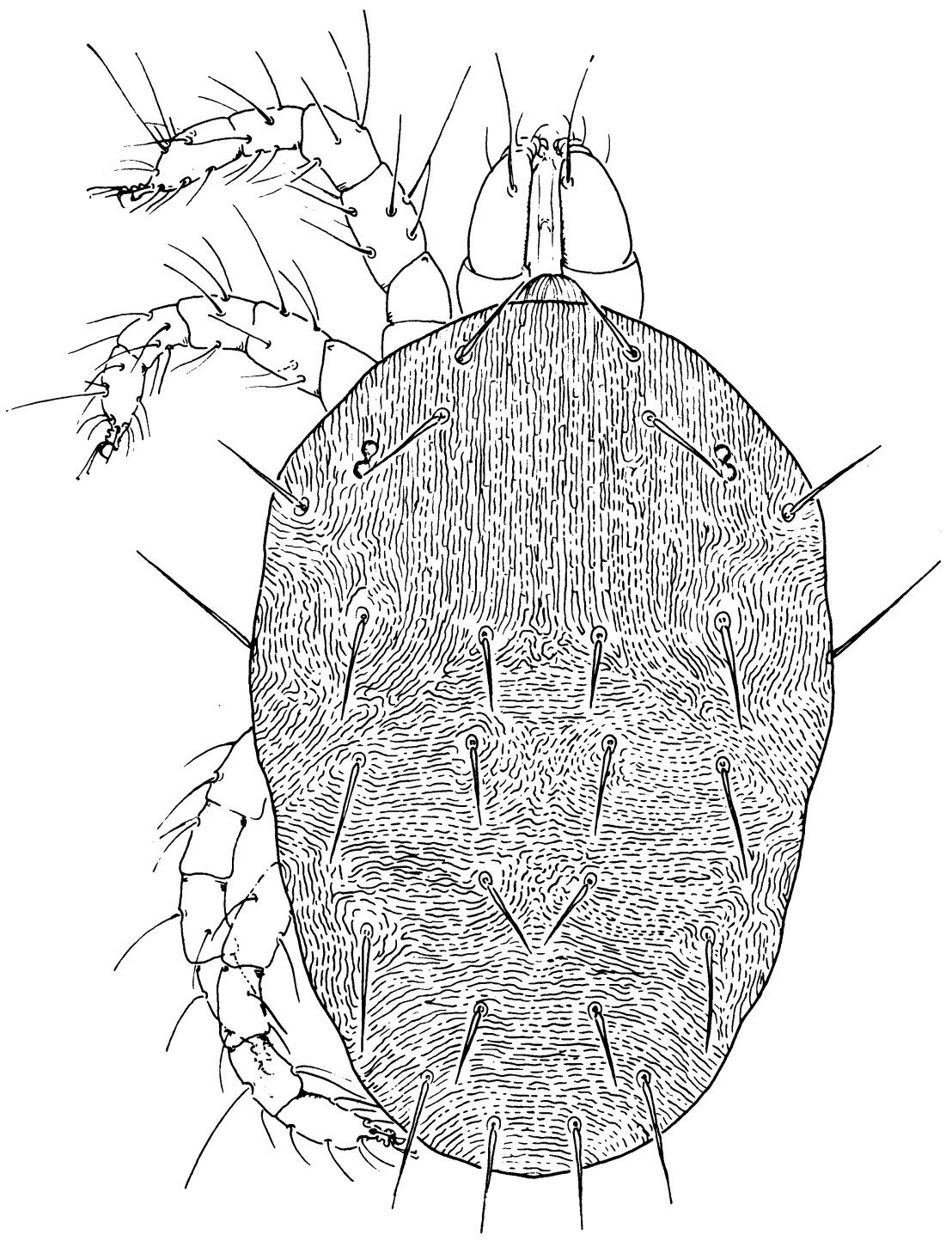

Fig. 35. Schizotetranychus gausus: dorsal aspect of female.

\section{Schizotetranychus gausus, new species}

(Figs. 35 to 38 )

The female of Schizotetranychus gausus resembles that of S. spireafolia (Garman) (northeastern United States) and S. avetjanae Bagdasarian (Armenia) in having the dorsocentral hysterosomals awl-shaped, nearly bare, and shorter than the longitudinal intervals between them, and the inner sacrals scarcely wider apart than the third dorsocentral hysterosomals. How- 


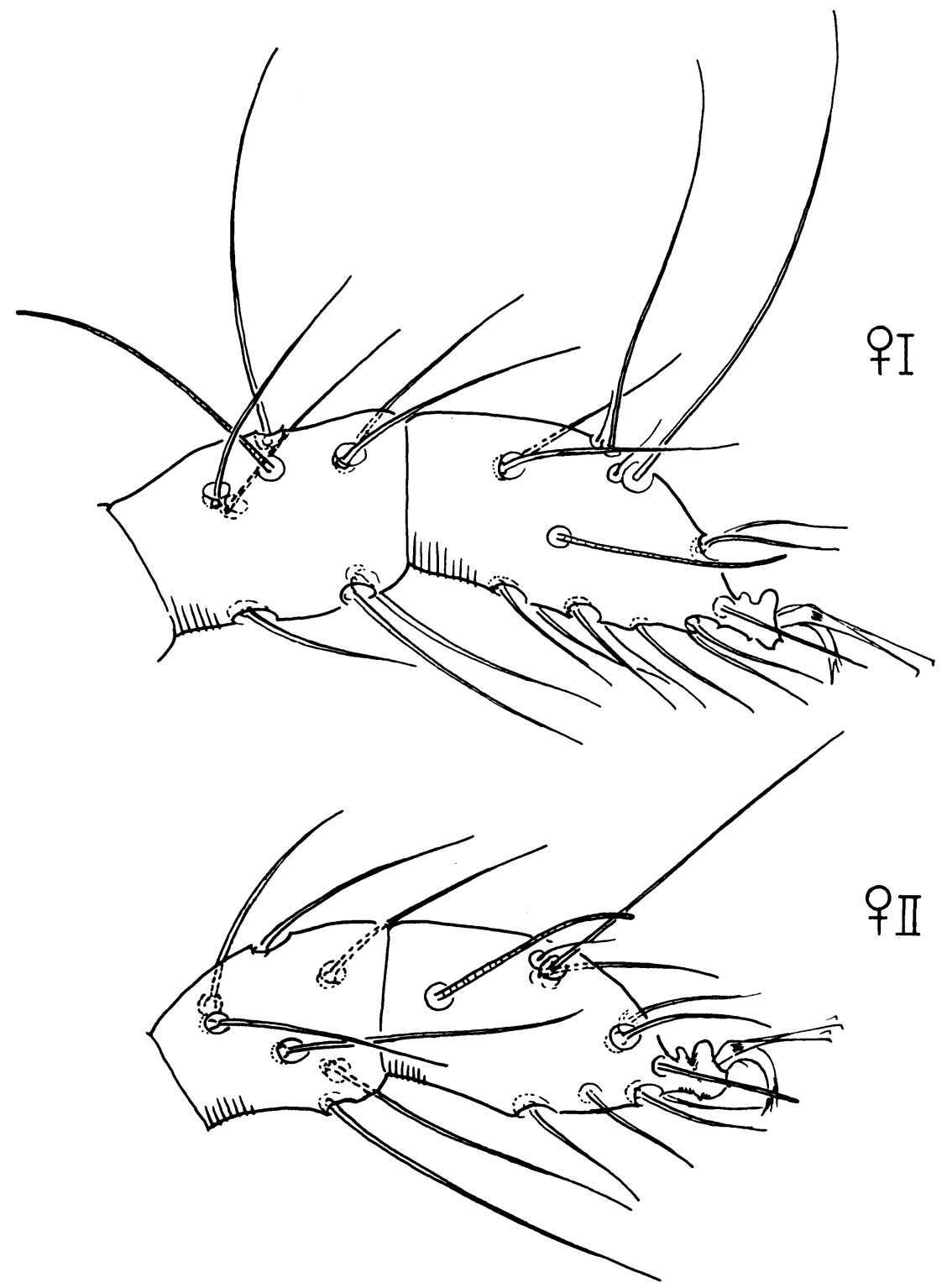

Fig. 36. Schizotetranychus gausus: tibia and tarsus I of female and tibia and tarsus II of female.

ever, the irregular striae between each pair of dorsocentrals is distinctive of gausus. The aedeagus of $S$. gausus is distinctive in having the distal end abruptly narrowed and bent slightly upward. 


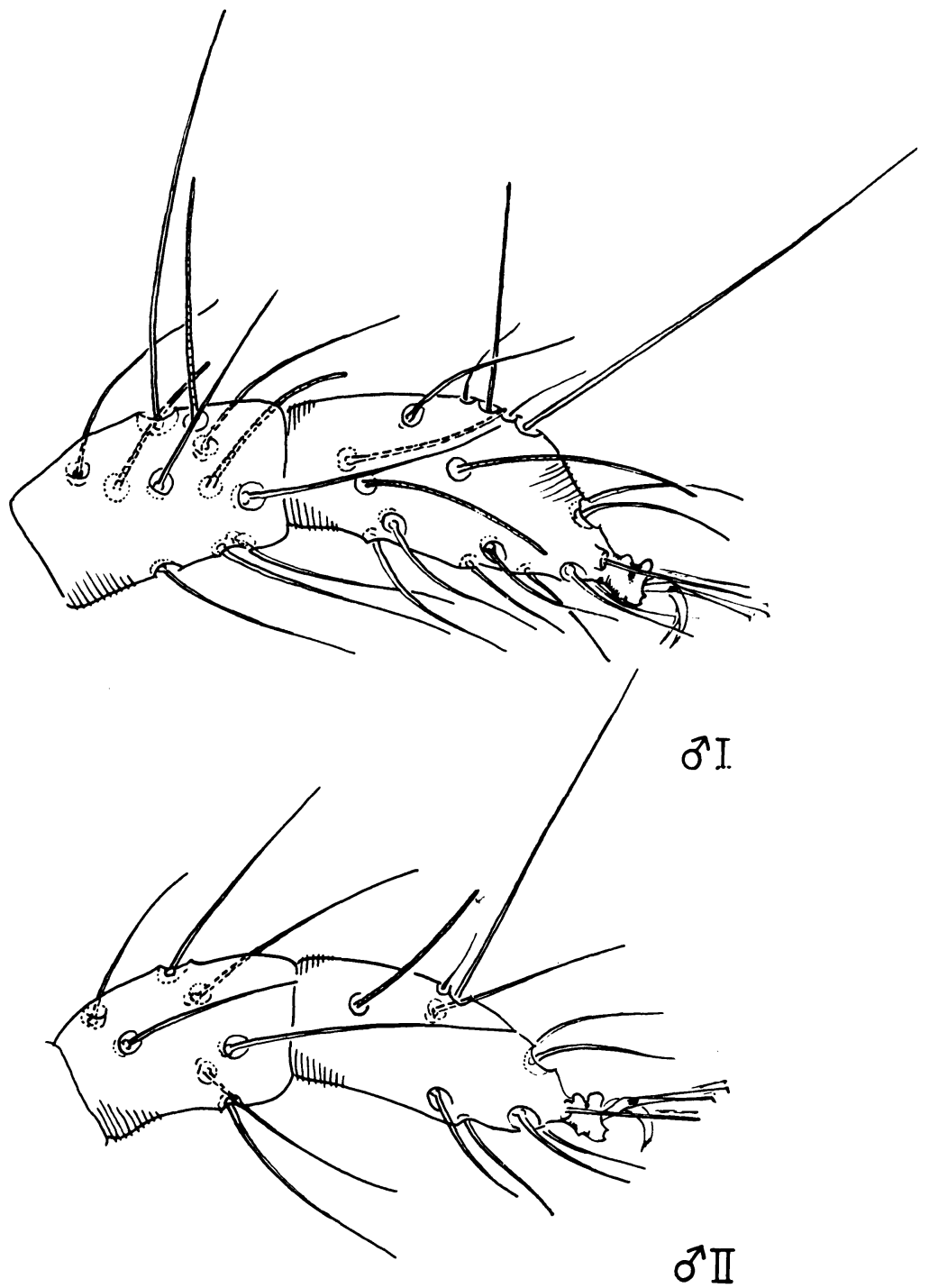

Fig. 37. Schizotetranychus gausus: tibia and tarsus I of male and tihia and tarsus II of male.

Male. Palpus with terminal sensillum very small. Stylophore evenly convex anteriorly. Peritreme straight and scarcely enlarged distally. Tibia I with eight tactile and three sensory setae; tarsus I with three tactile and three sensory setae proximal to duplexes; tibia II with seven tactile setae; em- 
podium with each clawlike member bearing a short, fine, dorsal hair and a very fine proximoventral hair. Dorsal integument finely striate, the striae bearing small, elongate lobes; propodosomal striae longitudinal; hysterosomal striae irregular between the dorsocentrals, otherwise transverse. Dorsal setae of idiosoma awl-shaped, nearly nude; dorsocentral hysterosomals a little over one half the length of distances between them ; lateral setae slightly longer ; inner sacrals spaced similarly to second dorsocentral hysterosomals. Aedeagus with shaft short and broad, abruptly narrowing from venter, the narrow distal part obtusely angulate with the tip directed dorsocaudad. Length of body $319 \mu$; greatest width of body $140 \mu$.

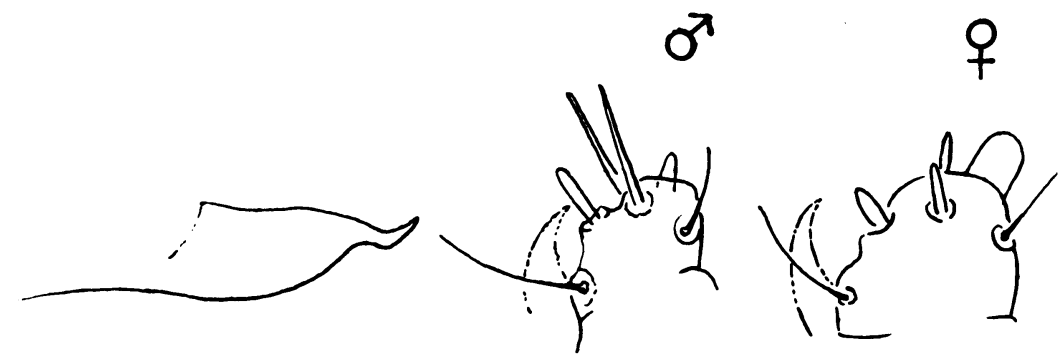

Fig. 38. Schizotetranychus gausus : aedeagus and terminal palpal segment of male and female.

Female. Palpus with terminal sensillum large, a little longer than broad. Tibia I with eight tactile and one sensory setae; tarsus I with four tactile and one sensory setae proximal to duplexes ; tibia II with seven tactile setae. Dorsal integument of body finely striate, the striae with small, elongate lobes; propodosoma with striae longitudinal ; hysterosoma with striae transverse except for irregular pattern between each pair of dorsocentrals. Dorsal setae of idiosoma similar to male. Length of body $414 \mu$; greatest width of body $223 \mu$.

Holotype. Male, IRSAC, Lwiro, Belgian Congo, May 18, 1955 (E. W. Baker), on tree legume; type no. 2496 in the U. S. National Museum.

Paratypes. Eleven males, 15 females, IRSAC, Lwiro, Belgian Congo, May 18,1955 (E. W. Baker), on tree legume.

\section{Schizotetranychus rhodanus, new species}

(Figs. 39, 40)

Schizotetranychus rhodanus is closely allied to S. gausus. The female of rhodanus has a cleft stylophore, however, and in the male the end of the aedeagus is more drawn out and undulate.

Male. Palpus with terminal sensillum minute. Stylophore cleft mediodistally. Peritreme ending in a simple bulb. Tibia I with eight tactile and 


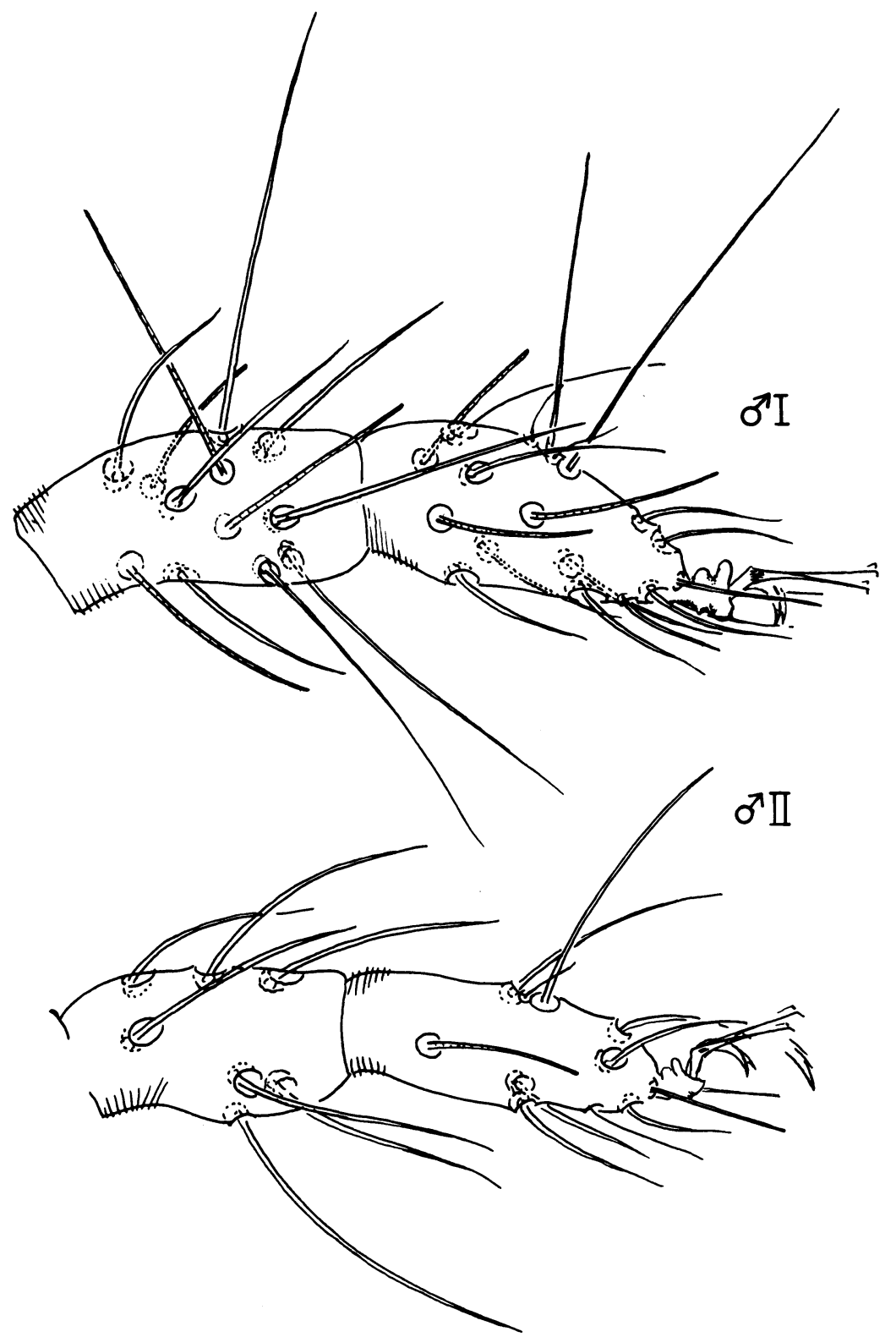

Fig. 39. Schizotetranychus rhodanus: tibia and tarsus I of male and tibia and tarsus II of male. 
four sensory setae; tarsus I with four tactile and two sensory setae proximal to duplexes; tibia II with seven tactile setae; empodium with a fine dorsal and a very fine proximoventral hair on each clawlike member. Dorsal integument of idiosoma with fine longitudinal striae bearing small, elongate lobes; propodosomal striae longitudinal and hysterosomal striae transverse except for irregularity in area between dorsocentrals. Dorsal setae of idiosoma awlshaped, nearly nude; dorsocentral hysterosomals shorter than longitudinal
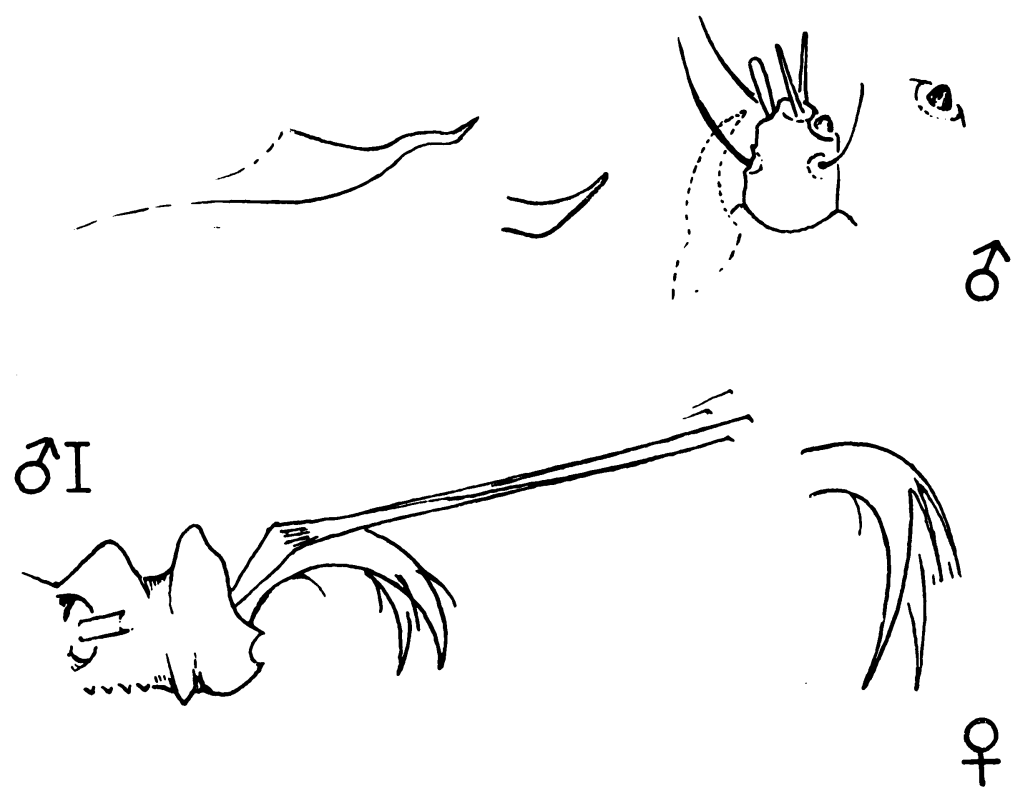

Fig. 40. Schizotetranychus rhodanus: aedeagus, terminal segment of palpus of male, empodium I of male, and empodium of female.

intervals between them, the lateral setae somewhat longer; inner clunals spaced similarly to second pair of dorsocentrals. Aedeagus with shaft broad at base and narrowing, the distal part about as long as shaft and undulate, with the tip directed slightly dorsocaudad. Length of body $370 \mu$; greatest width of body $145 \mu$.

Female. Palpus with terminal sensillum large, a little longer than broad. Tibia I with eight tactile and one sensory setae; tarsus I with four tactile and one sensory setae proximal to duplexes; tibia II with seven tactile setae. Dorsal integument of idiosoma and dorsal setae as in male. Length of body $382 \mu$; greatest width of body $127 \mu$.

Holotype. Male, Leopoldville, Belgian Congo, April 8, 1955 (E. W. Baker), on shade tree; type no. 2497 in the U. S. National Museum.

Paratypes. Six males, 12 females, Leopoldville, Belgian Congo (E. W. Baker), on shade tree. 


\section{GENUS OLIGONYCHUS BERLESE, 1886}

Oligonychus Berlese, 1886, Acari Dann. Piante Coltiv., p. 24.

The African species of Oligonychus may be recognized by the empodium's forming a well-developed "claw" bearing proximoventral hairs and the dorsum of the body without setigerous tubercles. The mites feed characteristically on perennial grasses or on the upper surfaces of leaves of shrubs and trees. The egg bears a dorsal stipe.

A study of Oligonychus gossypii and related African species shows that the Megregori group as recognized by Pritchard and Baker (1955) should be united with the Pritchardi group of species. Although the striation of the hysteroma of the female varies within the Pritchardi group, the type of aedeagus, empodium I of the male, and the host range separate it from the Pratensis group.

\section{Key to Species}

1. Tibia I with seven tactile setae; empodium with five pairs of proximoventral hairs; aedeagus bent ventrad (Ununguis group)....... 2

- Tibia I with nine tactile setae; empodium (except sometimes on leg I and II of male) with three pairs of proximoventral hairs; aedeagus

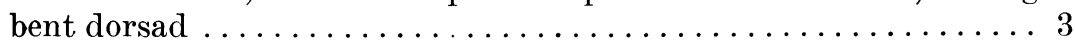

2. Aedeagus bent at right angle to shaft; female tarsus I with three tactile and one sensory setae proximal to the duplex setae........ (1) coffeae

- Aedeagus bent at an acute angle to shaft; female tarsus I with four tactile and one sensory setae proximal to the duplex setae

(2) mangiferus

3. Aedeagus with an acute dorsal angulation; empodium I of male with three pairs of proximoventral hairs (Pritchardi group).......4 4

- Aedeagus without an acute dorsal angulation; empodium I of male with a pair of proximoventral spurs (Pratensis group) ......... 8

4. Distal part of aedeagus with ventral side of bend undulate

(3) gossypii

- Distal part of aedeagus with ventral side of bend evenly curved....5

5. Tarsus I truncate distally and no longer than tibia I....... (7) calcis

- Tarsus I attenuated distally and much longer than tibia I.......6 6

6. Duplex setae on tarsus I with the members of each pair subequal in length; peritreme straight distally .............. (6) hadrus

- Duplex setae on tarsus I with the members of each pair very dissimilar in length; peritreme hooked distally................ 7

7. Aedeagus with dorsal margin of distal part sigmoid; female with terminal sensillum of palpus very slender............... (4) licinus

- Aedeagus with dorsal margin of distal part convex ; female with terminal sensillum of palpus short and broad...........(5) biharensis

8. Aedeagus enlarged or widened distally $\ldots \ldots \ldots \ldots \ldots \ldots \ldots$

- Aedeagus with distal portion sigmoid and tapering...........11

9. Knob of aedeagus with dorsal margin shallowly concave.... (8) simus

- Knob of aedeagus with dorsal margin convex................10 


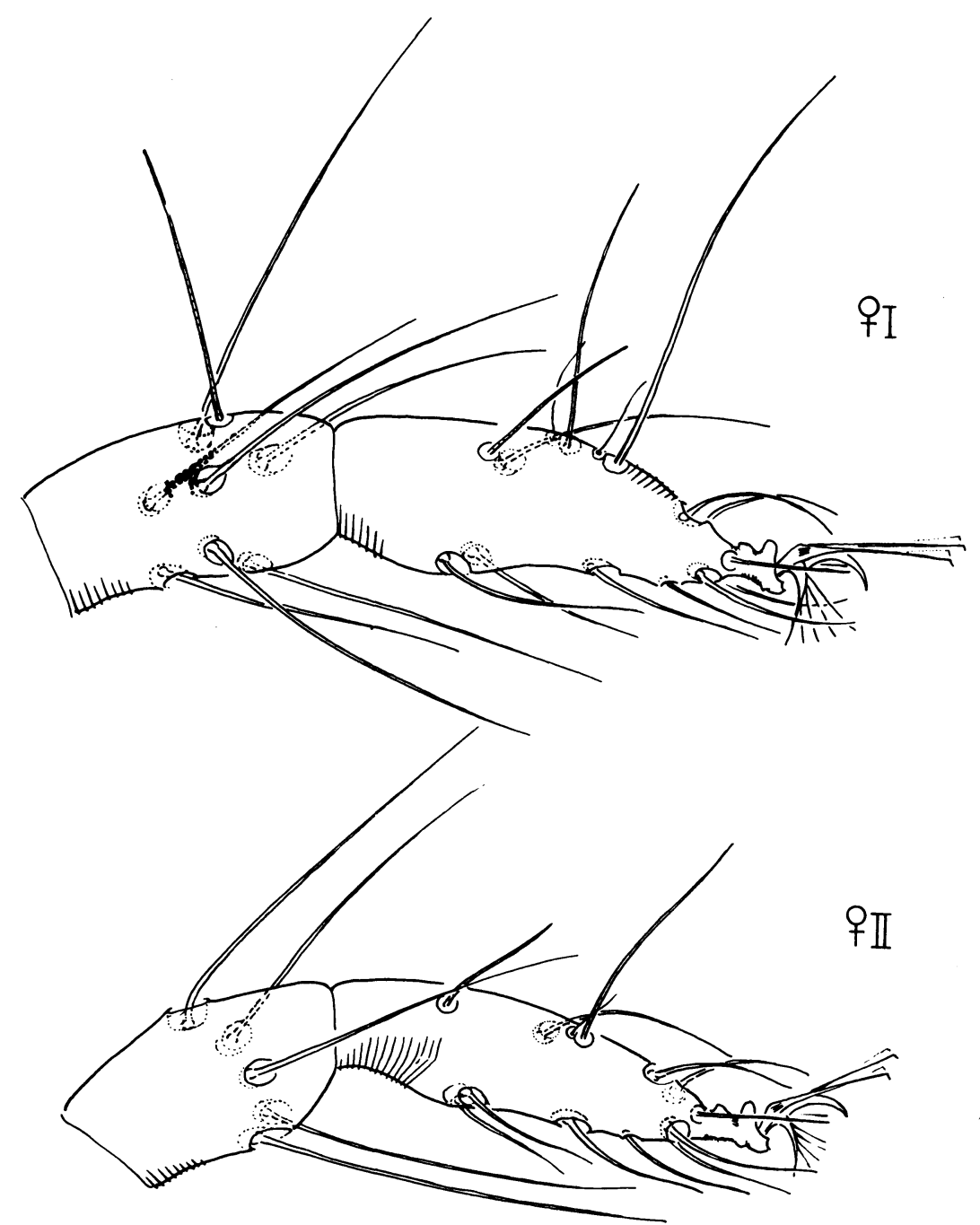

Fig. 41. Oligonychus coffeae: tibia and tarsus I of female and tibia and tarsus II of female.

10. Knob of aedeagus with a strong, broadly rounded development an-

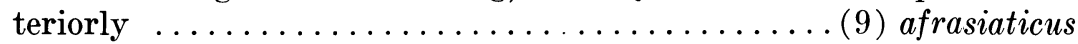

- Knob of aedeagus with slight development anteriorly.......(10) tylus

11. Aedeagus with dorsally directed part abruptly bent caudad

(11) saccharinus

- Aedeagus with dorsally directed part not sharply bent..........12

12. Aedeagus with dorsally directed part obtusely angulate near middle

- Aedeagus with dorsally directed part evenly curved.....(13) plegas 


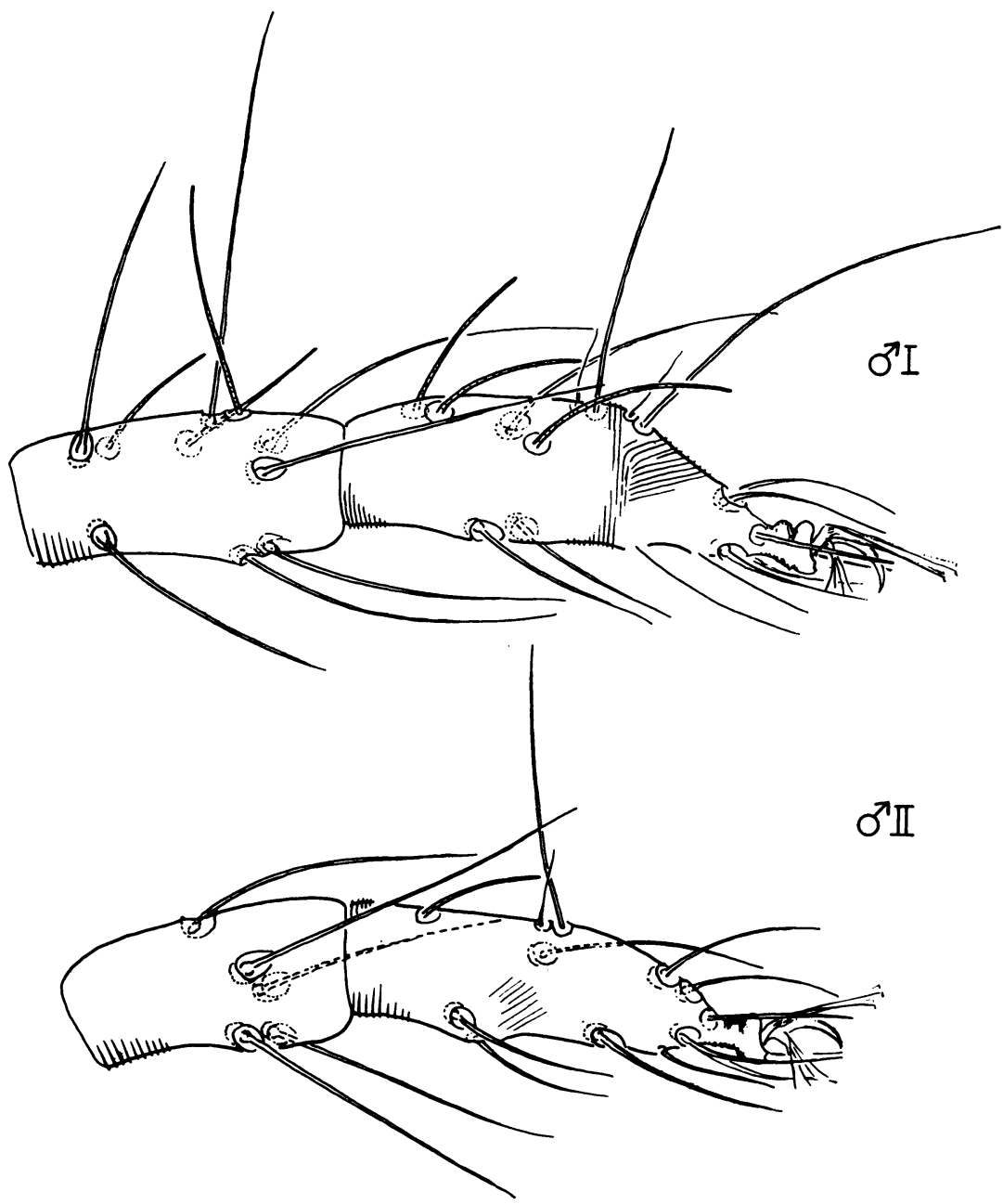

Fig. 42. Oligonychus coffeae: tibia and tarsus I of male and tibia and tarsus II of male.

\section{Oligonychus coffeae (Nietner)}

(Figs. 41, 42, 43)

Acarus coffeae Nietner, 1861, Observ. Enem. Coffee Tree Ceylon.

Oligonychus coffeae (Nietner), Pritchard and Baker, 1955, Mem. Pac. Coast Ent. Soc. 2: 315.

Oligonychus merwei Tucker, 1926, Ent. Mem. Dept. Agric. S. Afr. 5: 6. Paratetranychus terminalis Sayed, 1946, Bul. Soc. Fouad 1 ${ }^{\text {er }}$ Ent. 30: 94. New synonymy.

Oligonychus coffeae is a widespread species in the tropics, and it is recognized as a pest of coffee and tea. Specimens we have studied are from Ceylon, India, Mauritius, Africa, Florida, and Australia. 
The first record of this species (under the specific name merwei) in Africa was by Tucker (1926) on the basis of specimens from Stanger, Natal, on tea plants. Sayed (1946a) recognized this species (under the specific name terminalis) in Egypt on the basis of specimens collected on Magnifera indica, Terminalis sp., Eugenia gambolana, and Vitis vinifera. Pritchard and Baker (1955) recorded additional material from Pretoria, Transvaal, on Parthenocissus quinquefolia.
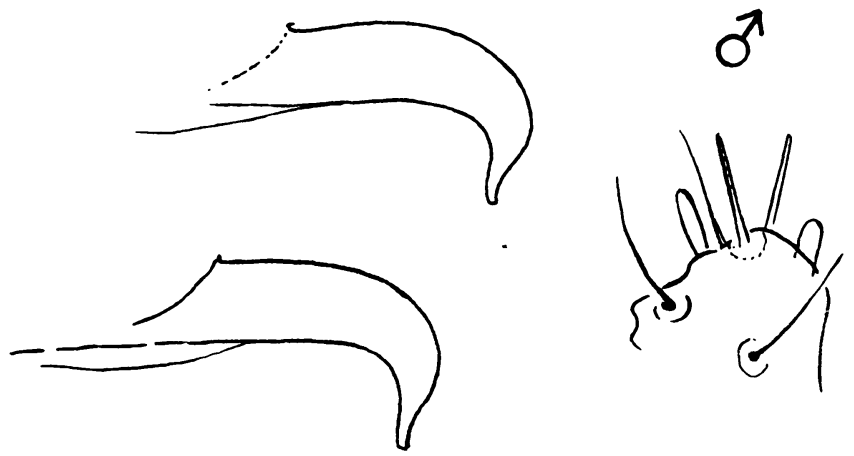

Fig. 43. Oligonychus coffeae: aedeagus and terminal segment of male palpus.

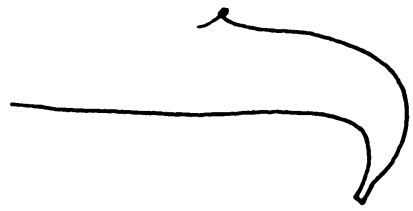

Fig. 44. Oligonychus mangiferus: aedeagus.

The following new records are from the Ethiopian region: Matugla, Kenya, September, 1955 (P. E. Wheatly), on cashew nut; Tori, Kenya, March 26, 1955 (R. LePelley), on unnamed host; Nioka, Belgian Congo, May 2, 1955 (E. W. Baker), on frangipani; Stanleyville, Belgian Congo, April 18, 1955 (E. W. Baker), on oil palm; INEAC, Mulunga, Belgian Congo, May 18, 1955 (E. W. Baker), on grape leaf ; Nelspruit, Transvaal, February, 1953 (H. K. Munro), on Eucalyptus; Nelspruit, Transvaal, April 24, 1953 (H. K. Munro), on eitrus; Mayfern, Transvaal, April 24, 1953 (H. K. Munro), on eitrus; Bean Bassin, Mauritius; September, 1955 (L. A. Moutia), on mango ; and Barkly, Mauritius, February, 1955 (L. A. Moutia), on cotoneaster.

\section{Oligonychus mangiferus (Rahman and Sapra)}

(Figs. 44, 45)

Paratetranychus mangiferus Rahman and Sapra, 1940, Proc. Ind. Acad. Sci. (ser. B) 11: 192.

Oligonychus mangiferus (Rahman and Sapra), Moutia, 1958, Bul. Ent. Res. 49: 60 . 


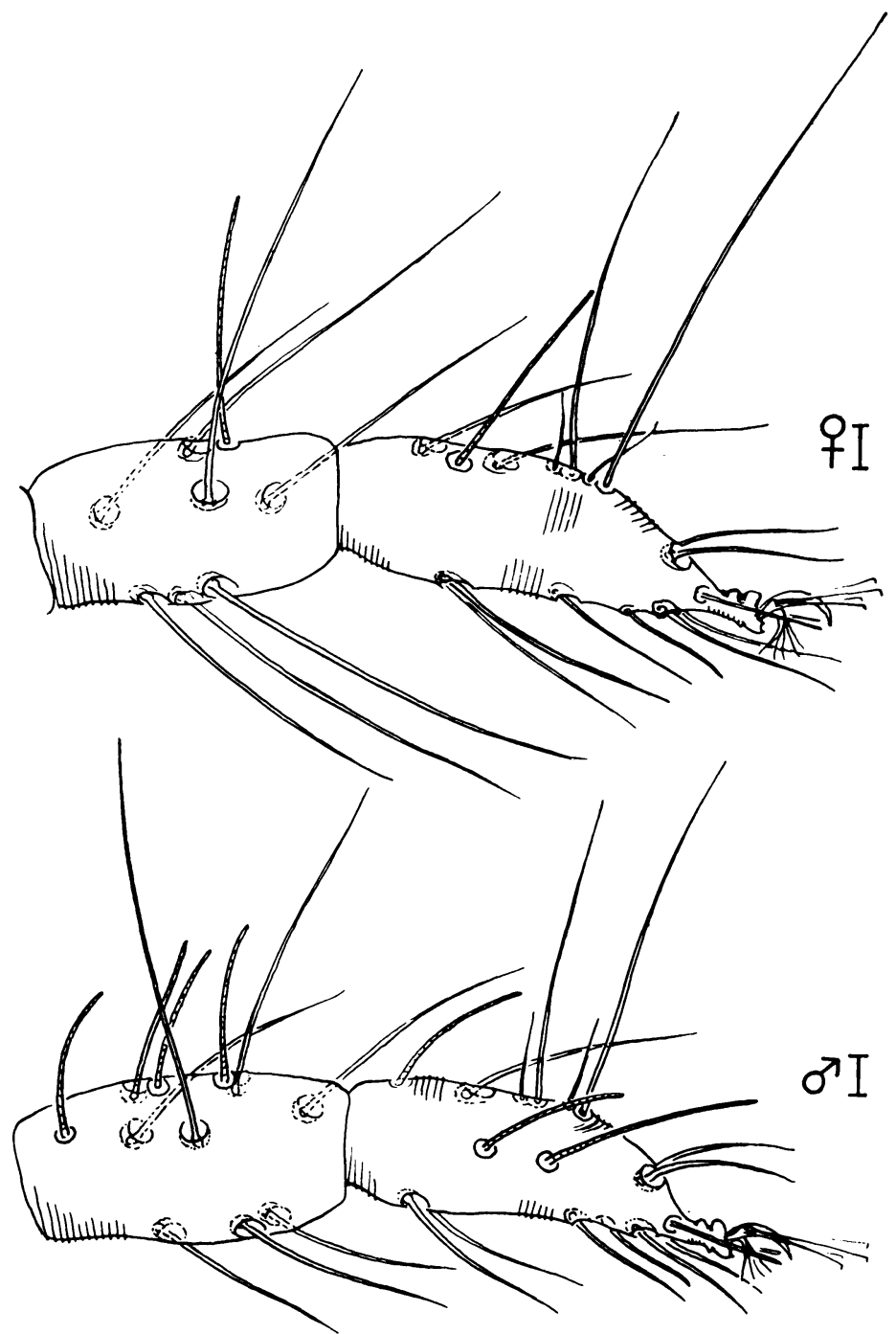

Fig. 45. Oligonychus mangiferus: tibia and tarsus I of female and tibia and tarsus I of male.

Oligonychus mangiferus is widespread in the tropics. We have studied material from India, Mauritius, Hawaii, and Peru. Moutia (1958) stated that it may cause damage to mango in Mauritius, and he also recorded it as occurring on peach and loquat. Annona, Vitis, Rosa, and Eugenia are also known to be hosts.

The specimens from Mauritius that we have studied are from Beau Bassin, September, 1955 (L. A. Moutia), on mango. 


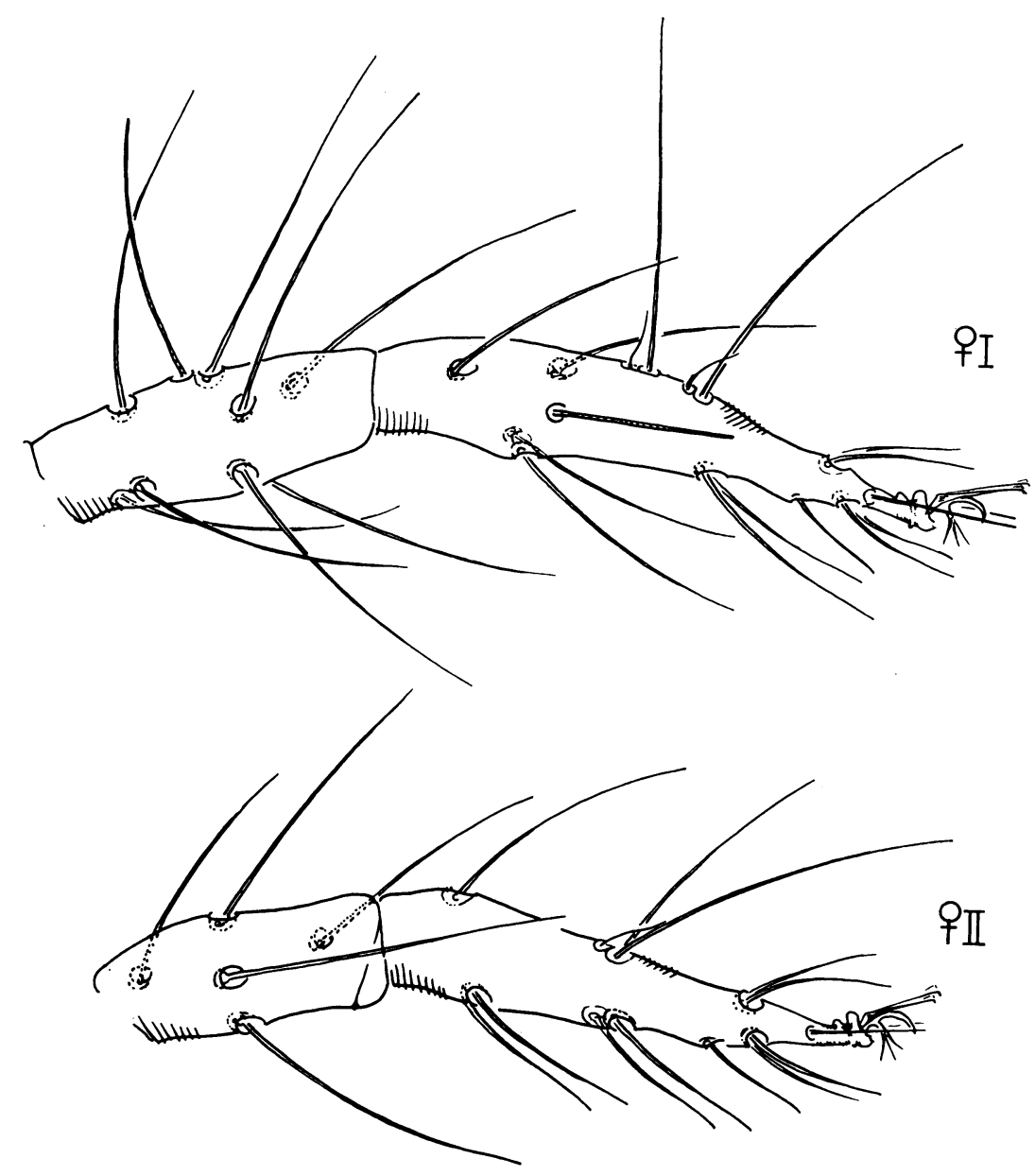

Fig. 46. Oligonychus gossypii: tibia and tarsus I of female and tibia and tarsus II of female.

\section{Oligonychus gossypii (Zacher)}

(Figs. 46, 47, 48)

Paratetranychus gossypii Zacher, 1921, Zts. Angew. Ent. 7: 183; Hirst, 1926, Proc. Zool. Soc. Lond. 1926: 832 ; André, 1933, Bul. Mus. Hist. Nat. Paris (sér. 2) 5: 306; Baker and Pritchard, 1953, Hilgardia 22 (7) : 209.

Oligonychus gossypii (Zacher), Pritchard and Baker, 1955, Mem. Pac. Coast Ent. Soc. 2: 359.

Oligonychus gossypii is known only from equatorial Africa, where it is widespread and common. Zacher (1921) first recognized this species from 


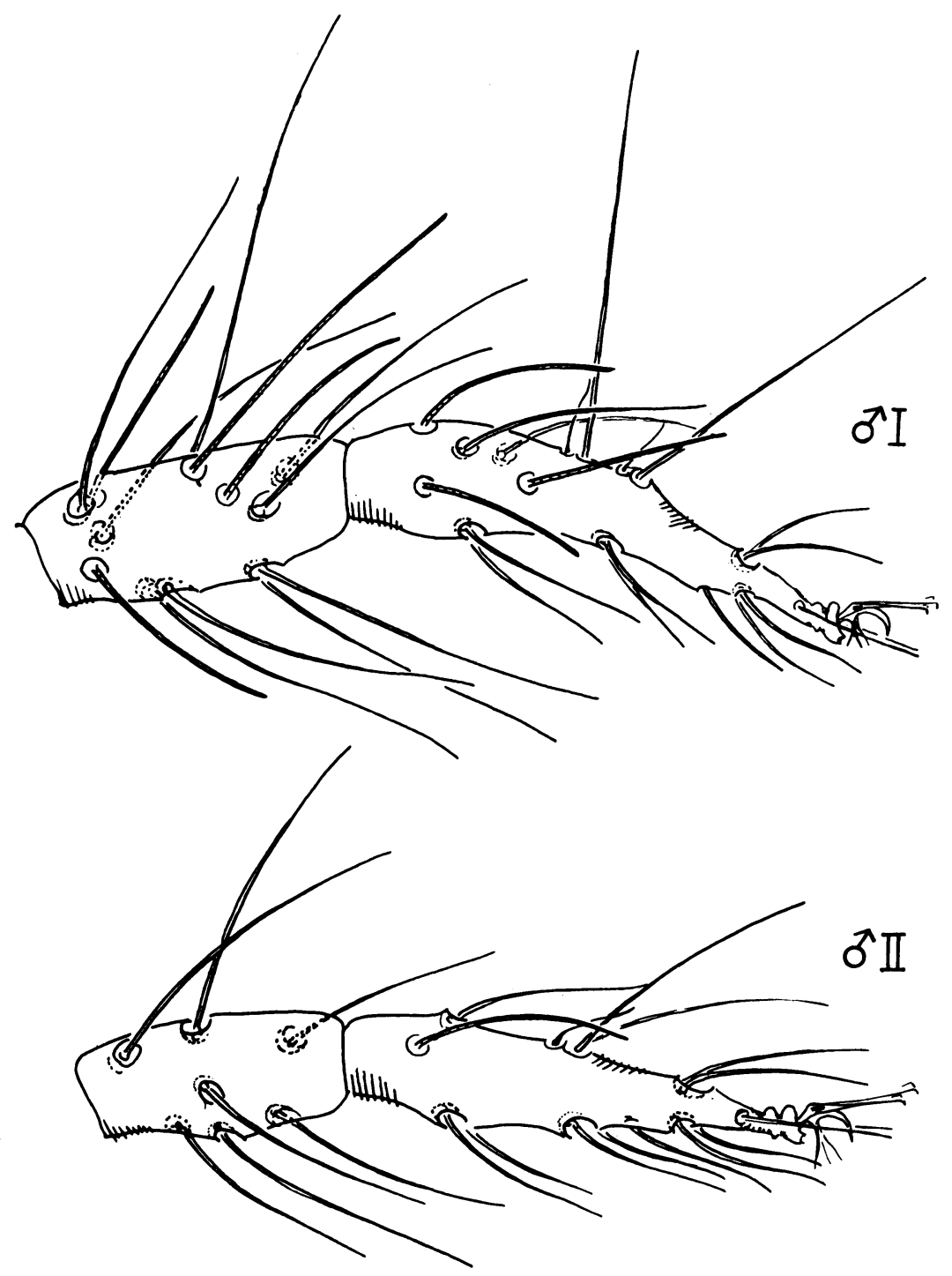

Fig. 47. Oligonychus gossypii: tibia and tarsus I of male and tibia and tarsus II of male.

Togo, French West Africa, as a cotton pest. Hirst (1926) recorded it from Sierra Leone, on cassava and beans, and from Portuguese West Africa, on papaya.

Specimens that we have examined are from Samara, Nigeria, December 
18, 1949 (Q. A. Geering), on cotton; Stanleyville, Belgian Congo, April 18-19, 1955 (E. W. Baker), on Bridelia sp., Berlinia sp., and manioc; Leopoldville, Belgian Congo, April 8-11, 1955 (E. W. Baker), on Combetrum sp., shade trees, euphorbiaceous and acanthaceous plants; Paulis, Belgian Congo, April 28, 1955 (E. W. Baker), on rose; Mt. Hoyo, Belgian Congo, May 4, 1955 (E. W. Baker), on citrus and peach ; Beni, Belgian Congo, May 7, 1955 (E. W. Baker), on peach; and Dungu, Belgian Congo, April 29, 1955 (E. W. Baker), on Acacia sp.
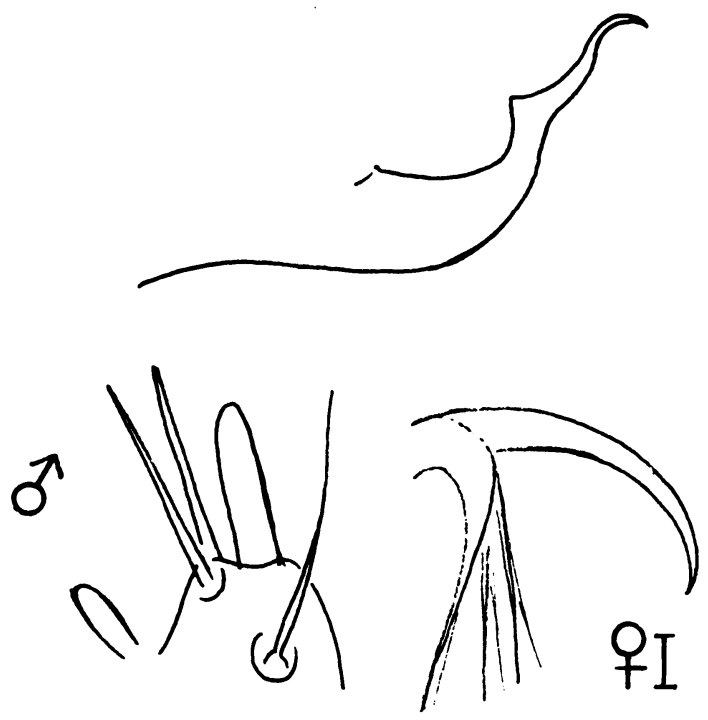

Fig. 48. Oligonychus gossypii: aedeagus, termination of palpus of male, and empodium I of female.

\section{Oligonychus licinus, new species}

(Figs. 49 to 52 )

Oligonychus licinus resembles $O$. gossypii in that the peritreme is strongly hooked distally, the dorsal integument of the female bears longitudinal striae between both the third pair of dorsocentral hysterosomals and the inner sacrals, and the dorsal margin of the distal part of the aedeagus is sigmoid. The ventral margin of the distal part of the aedeagus, however, is evenly convex except at the tip.

Male. Palpus with terminal sensillum very long and slender. Peritreme with a strong hook distally. Tibia I with nine tactile and four sensory setae; tarsus I attenuated, with four tactile and three sensory setae proximal to duplexes; duplex setae with members of each pair unequal in length; 


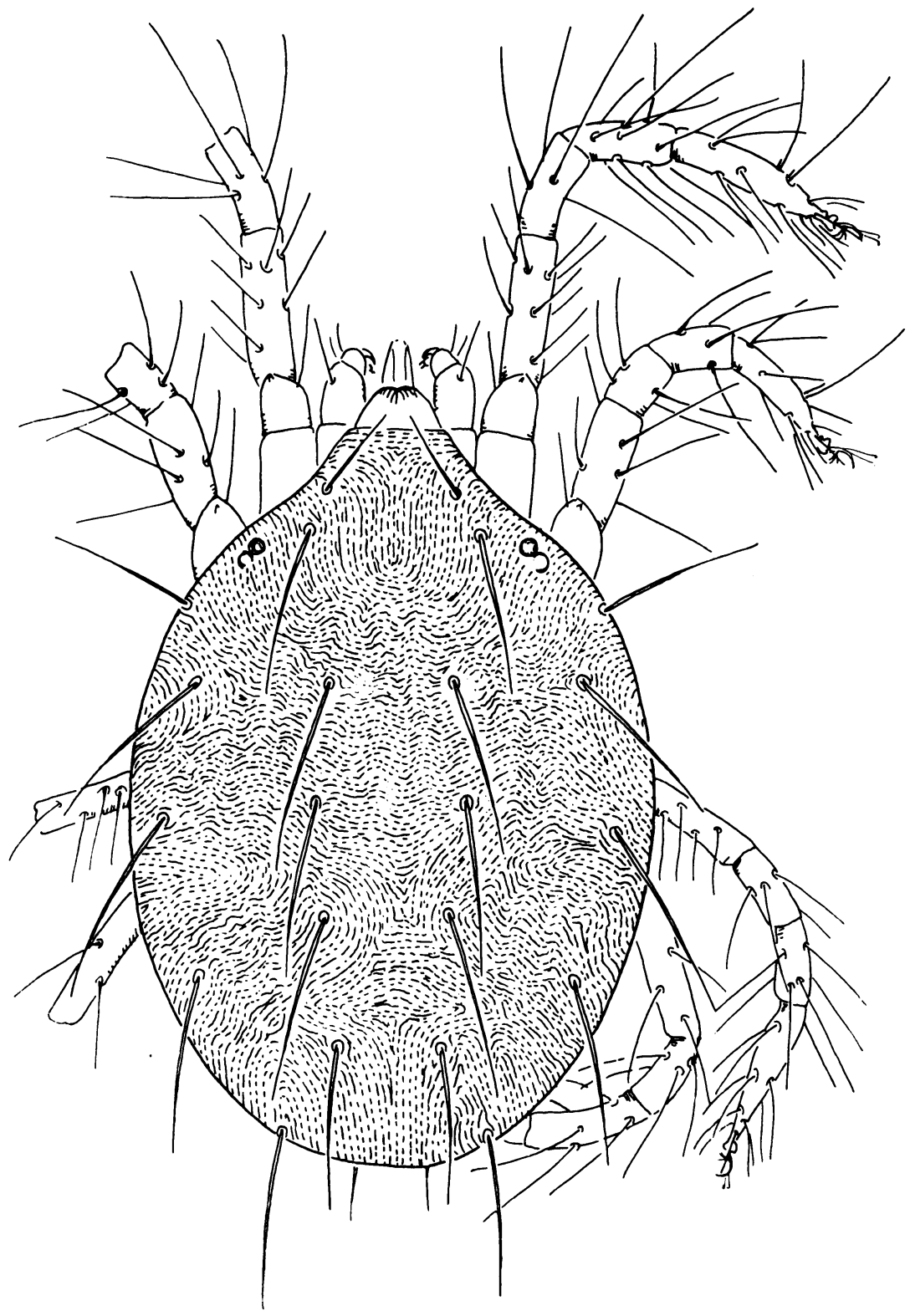

Fig. 49. Oligonychus licinus: dorsal aspect of female. 


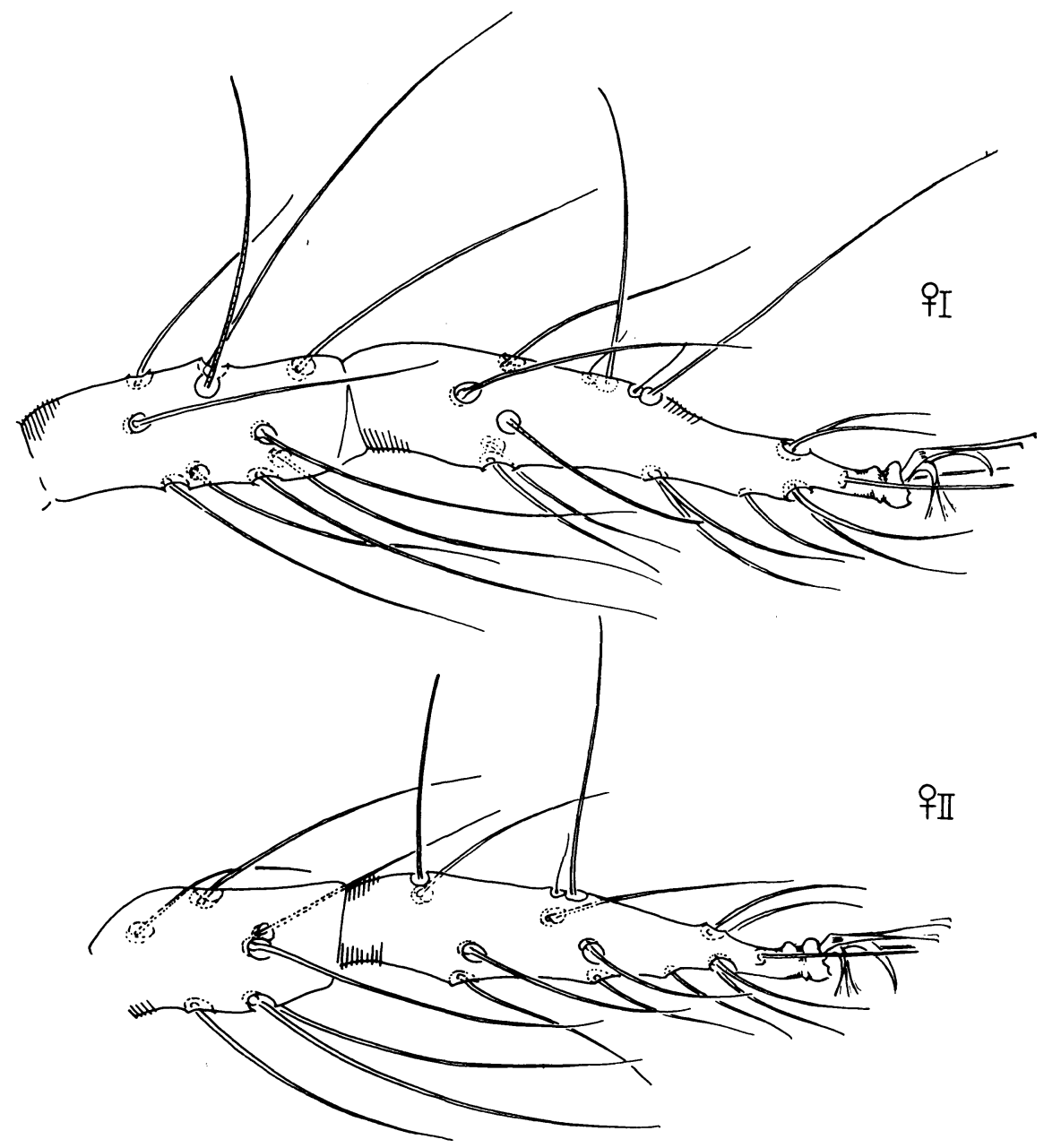

Fig. 50. Oligonychus licinus: tibia and tarsus I of female, and tibia and tarsus II of female.

empodium I with three pairs of proximoventral hairs. Tibia II with seven tactile setae. Dorsal setae of idiosoma long and slender, pubescent. Aedeagus with shaft gradually narrowing, the distal part strongly curved dorsad, bearing an acute angulation and with the tip narrowly tapering and deflexed. Length of body $320 \mu$; greatest width of body $140 \mu$.

Female. Palpus with terminal sensillum long and slender but shorter than in male. Tibia I with nine tactile and one sensory setae; tarsus I with four 


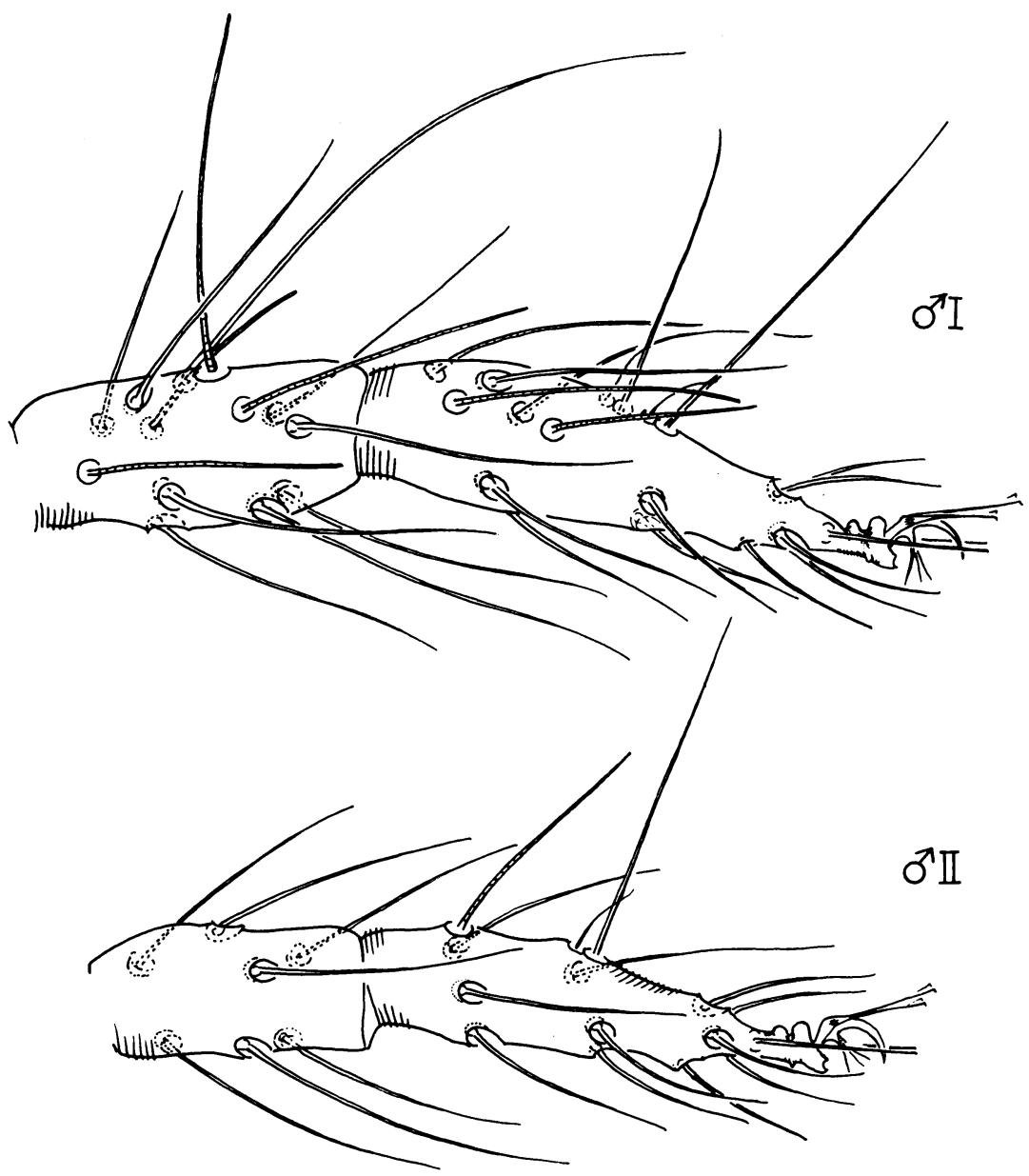

Fig. 51. Oligonychus licinus: tibia and tarsus I of male and tibia and tarsus II of male.

tactile and one sensory setae proximal to duplexes. Tibia II with seven tactile setae. Dorsal integument of idiosoma with transverse, lobed striae except for longitudinal striae between the third pair of dorsocentral hysterosomals and the inner sacral setae. Length of body $395 \mu$; greatest width of body $248 \mu$.

Holotype. Male, Stanleyville, Belgian Congo, April 20, 1955 (E. W. Baker), on wild plant; type no. 2497 in the U. S. National Museum.

Paratypes. Three males, 22 females, Stanleyville, Belgian Congo, April 20, 1955 (E. W. Baker), on wild plant. 

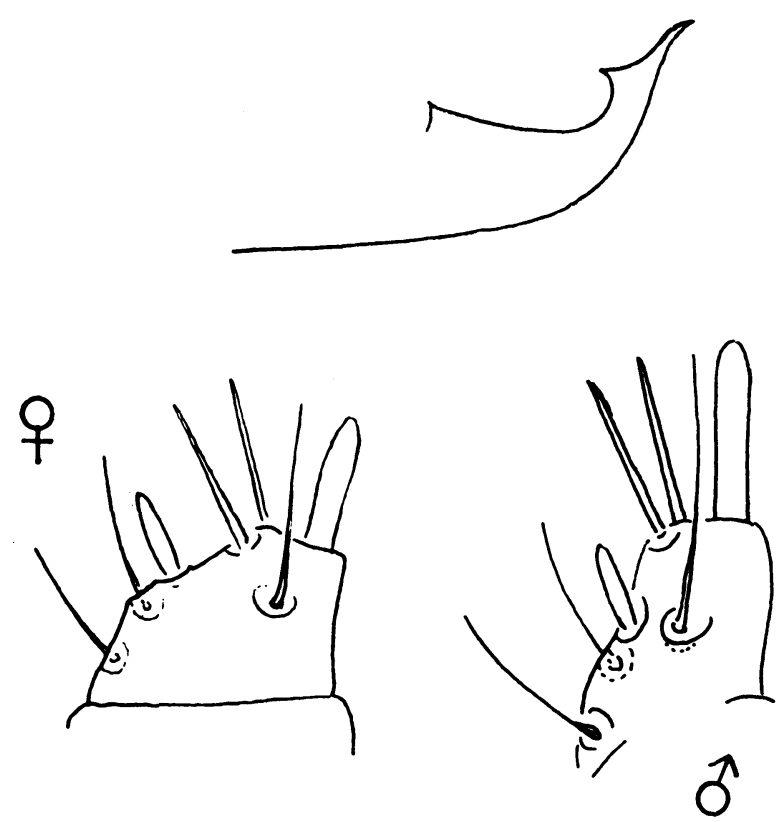

Fig. 52. Oligonychus licinus: aedeagus, terminal segment of male palpus, and terminal segment of female palpus.

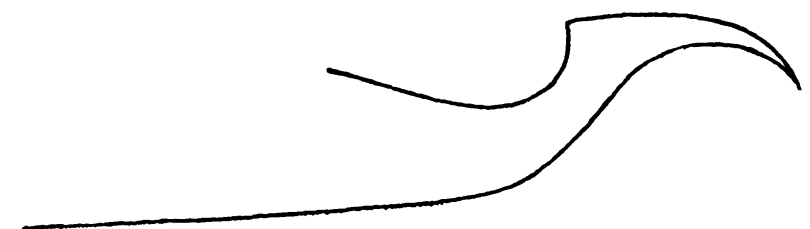

Fig. 53. Oligonychus biharensis: aedeagus.

\section{Oligonychus biharensis (Hirst)}

(Figs. 53, 54)

Paratetranychus biharensis Hirst, 1924, Proc. Zool. Soc. Lond. 1924: 69. Oligonychus biharensis (Hirst), Moutia, 1958, Bul. Ent. Res. 49: 60.

Oligonychus biharensis is a widespread species in the tropics. It has been recorded from India, Mauritius, Hawaii, and Antigua; on rose, loquat, mango, litchi, cotoneaster, camphor, and longane (Euphorbia longana). Ethiopian specimens that we have examined are from Beau Bassin, Mauritius, September, 1955 (L. A. Moutia), on loquat. 


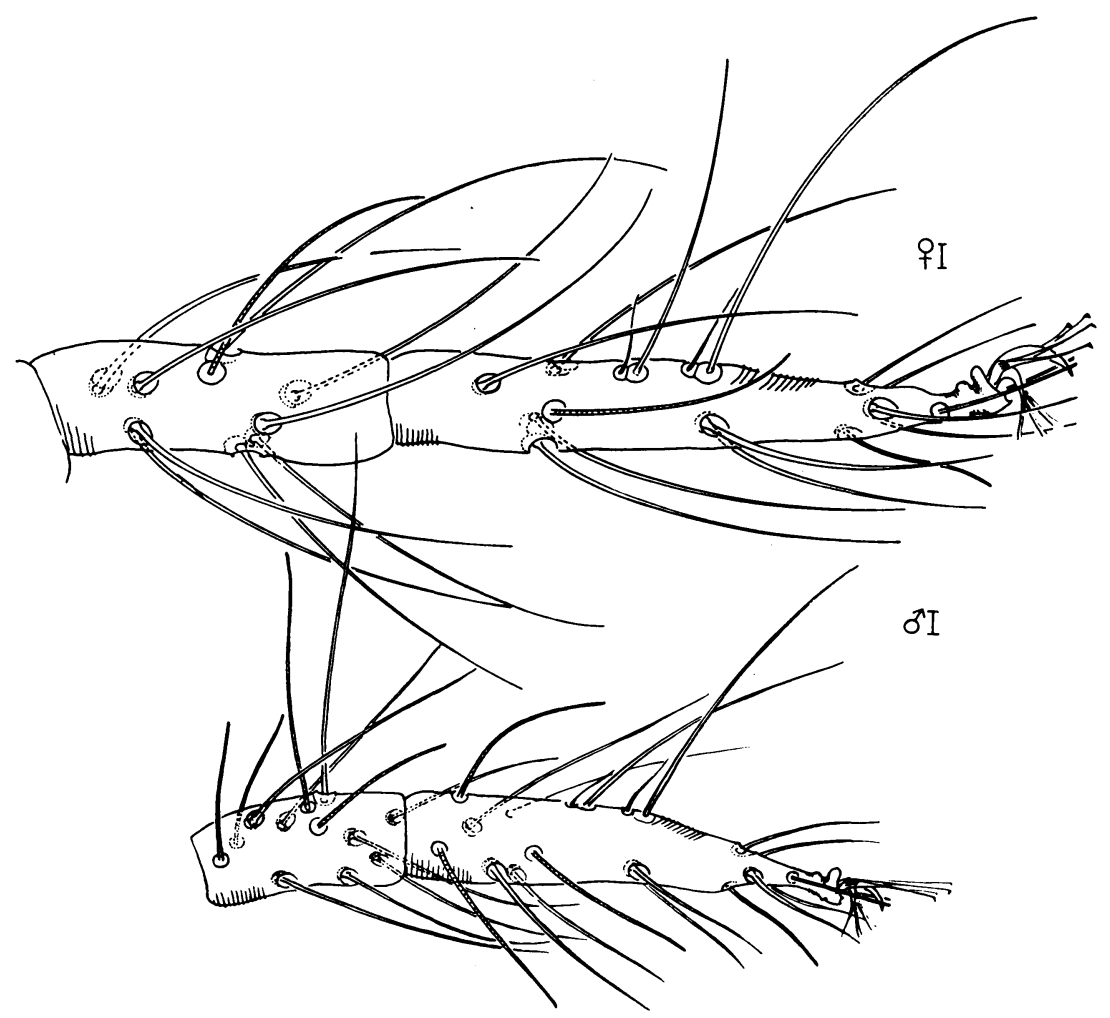

Fig. 54. Oligonychus biharensis: tibia and tarsus I of female and tibia and tarsus II of female.

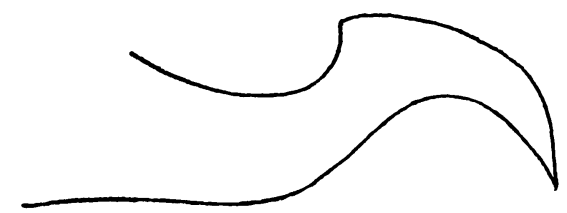

Fig. 55. Oligonychus hadrus: aedeagus.

\section{Oligonychus hadrus Pritchard and Baker}

(Fig. 55)

Oligonychus hadrus Pritchard and Baker, 1955, Mem. Pac. Coast Ent. Soc. 2: 369 .

This species is known only from the type series from Pretoria, Transvaal, South Africa, on Combretum zeyheri. 


\section{Oligonychus calcis, new species}

(Figs. 56 to 59 )

Oligonychus calcis may be recognized by having three pairs of proximoventral empodial hairs, nine tactile setae on tibia $I$, and the tarsi very short and abruptly declivate distally. The female further differs from other members of the Pritchardi group in that the dorsal striae of the hysterosoma are all smooth and transverse.

Male. Palpus with terminal sensillum rudimentary. Peritreme ending in a simple bulb. Tibia I with nine tactile and three sensory setae; tarsus I

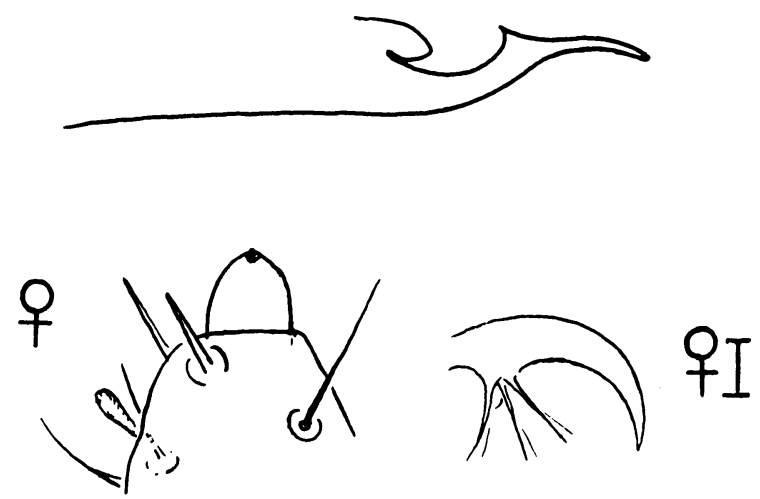

Fig. 56. Oligonychus calcis: aedeagus, termination of female palpus, and empodium I of female.

similar in length to tibia I and truncate distally, bearing two tactile and one sensory setae proximal to duplexes; duplex setae with members of each pair dissimilar in length; empodium I strongly curved and bearing three pairs of short, fine, proximoventral hairs. Tibia II with six tactile setae. Dorsal setae of idiosoma slender and serrate. Aedeagus with shaft strongly curved upward almost from base, the distal part with an acute dorsal angulation and distally tapering caudad. Length of body $261 \mu$; greatest width of body $96 \mu$.

Female. Palpus with terminal sensillum well developed, about as long as broad. Tibia I with nine tactile and two sensory setae; tarsus I with two tactile and one sensory setae proximal to duplexes. Tibia II with six tactile setae. Dorsal integument of hysterosoma with striae all transverse and smooth. Length of body $293 \mu$; greatest width of body $153 \mu$.

Holotype. Male, Stanleyville, Belgian Congo, April 18, 1955 (E. W. Baker), on Baphia solbeidi; type no. 2498 in the U. S. National Museum.

Paratypes. Nine males, 24 females, Stanleyville, Belgian Congo, April 18, 1955 (E. W. Baker), on Baphia solbeidi. 


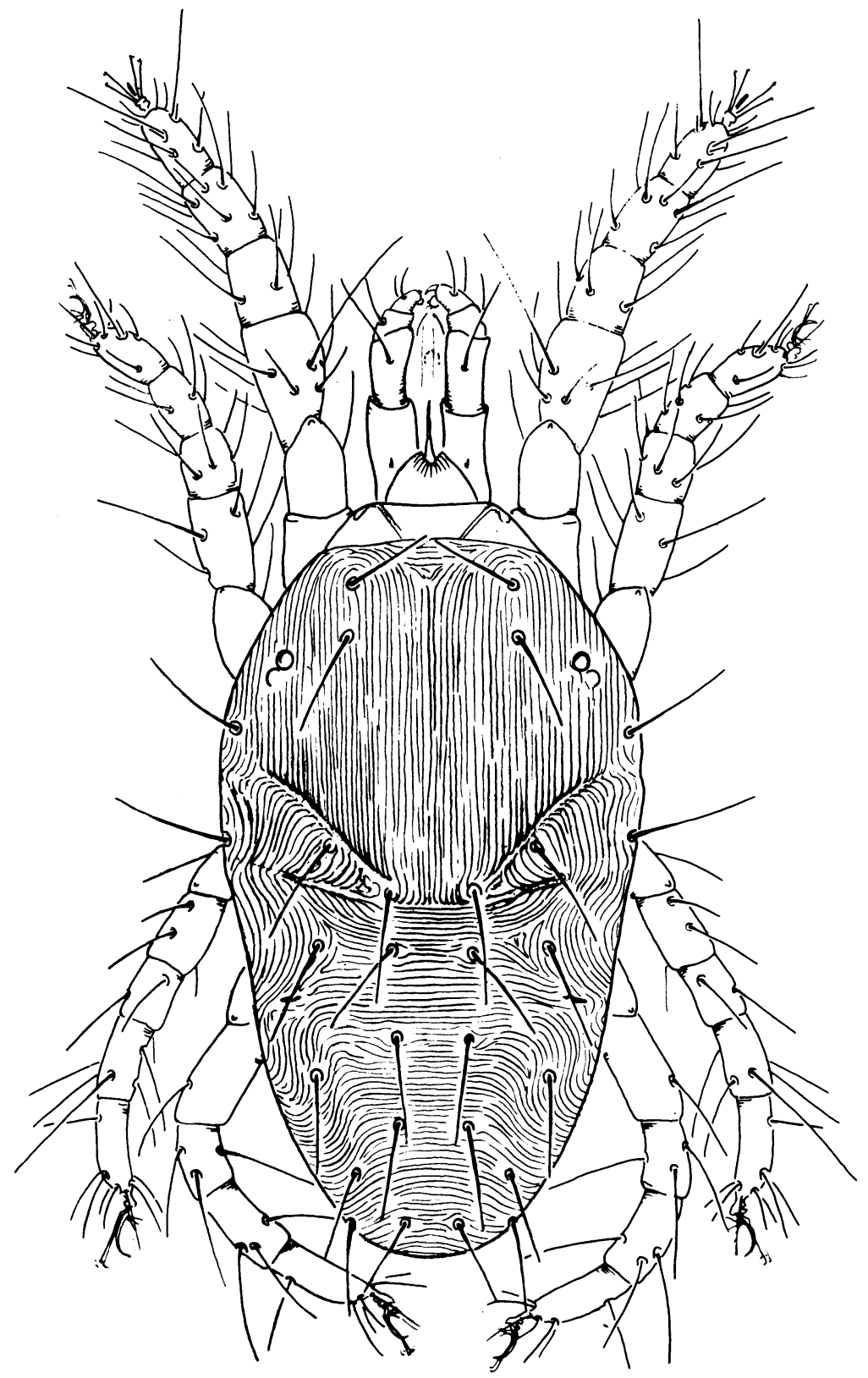

Fig. 57. Oligonychus calcis: dorsal aspect of female. 


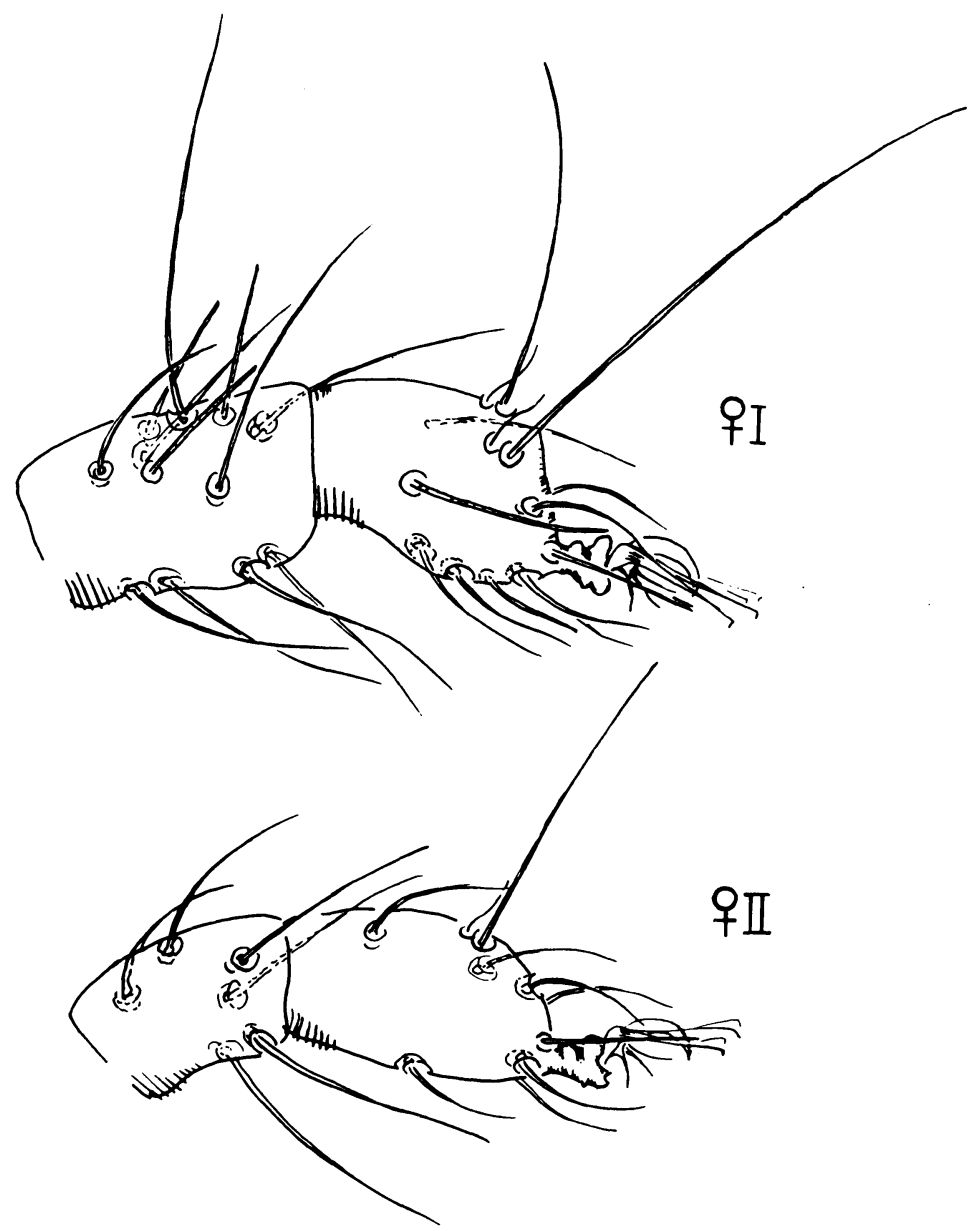

Fig. 58. Oligonychus calcis: tibia and tarsus I of female and tibia and tarsus II of female. 

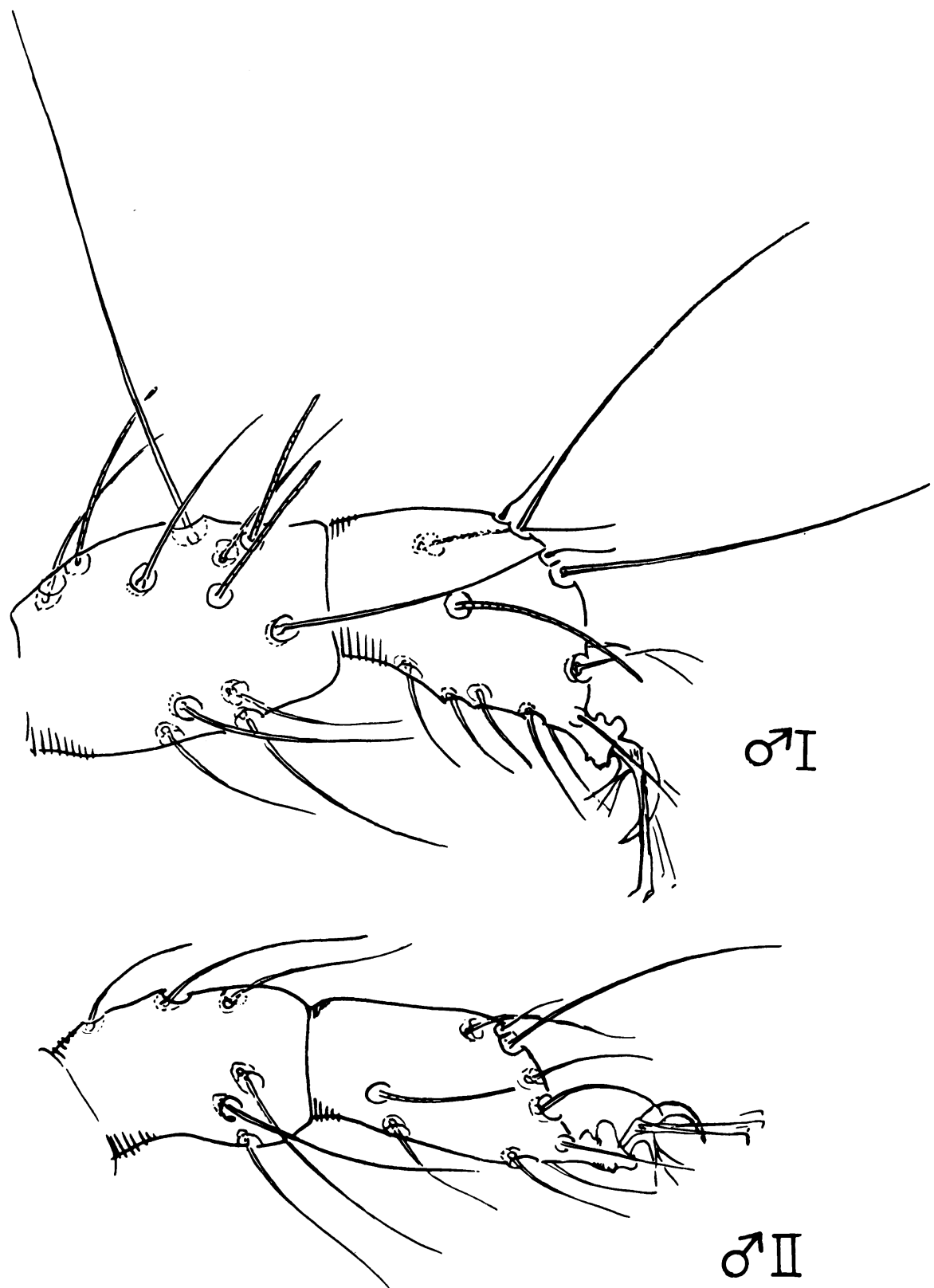

Fig. 59. Oligonychus calcis: tibia and tarsus I of male and tibia and tarsus II of male. 


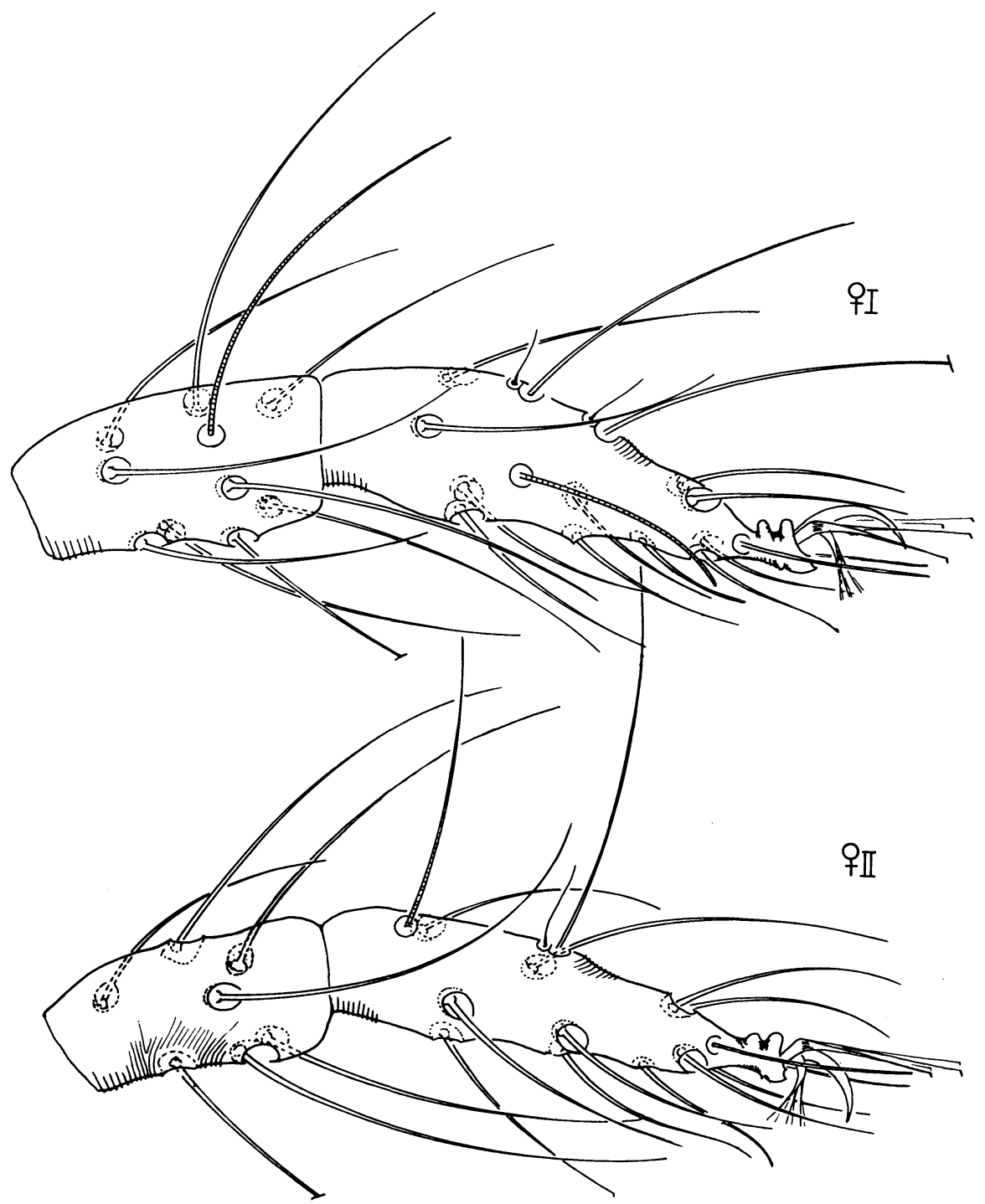

Fig. 60. Oligonychus simus: tibia and tarsus I of female and tibia and tarsus II of female.

\section{Oligonychus simus, new species}

(Figs. 60, 61, 62)

The aedeagus of Oligonychus simus resembles that of $O$. indicus (Hirst) (India) in that the distal end is slightly widened with the dorsal margin shallowly concave. It differs from indicus in that the caudal angle of the widened end of the aedeagus is strongly produced dorsad. 


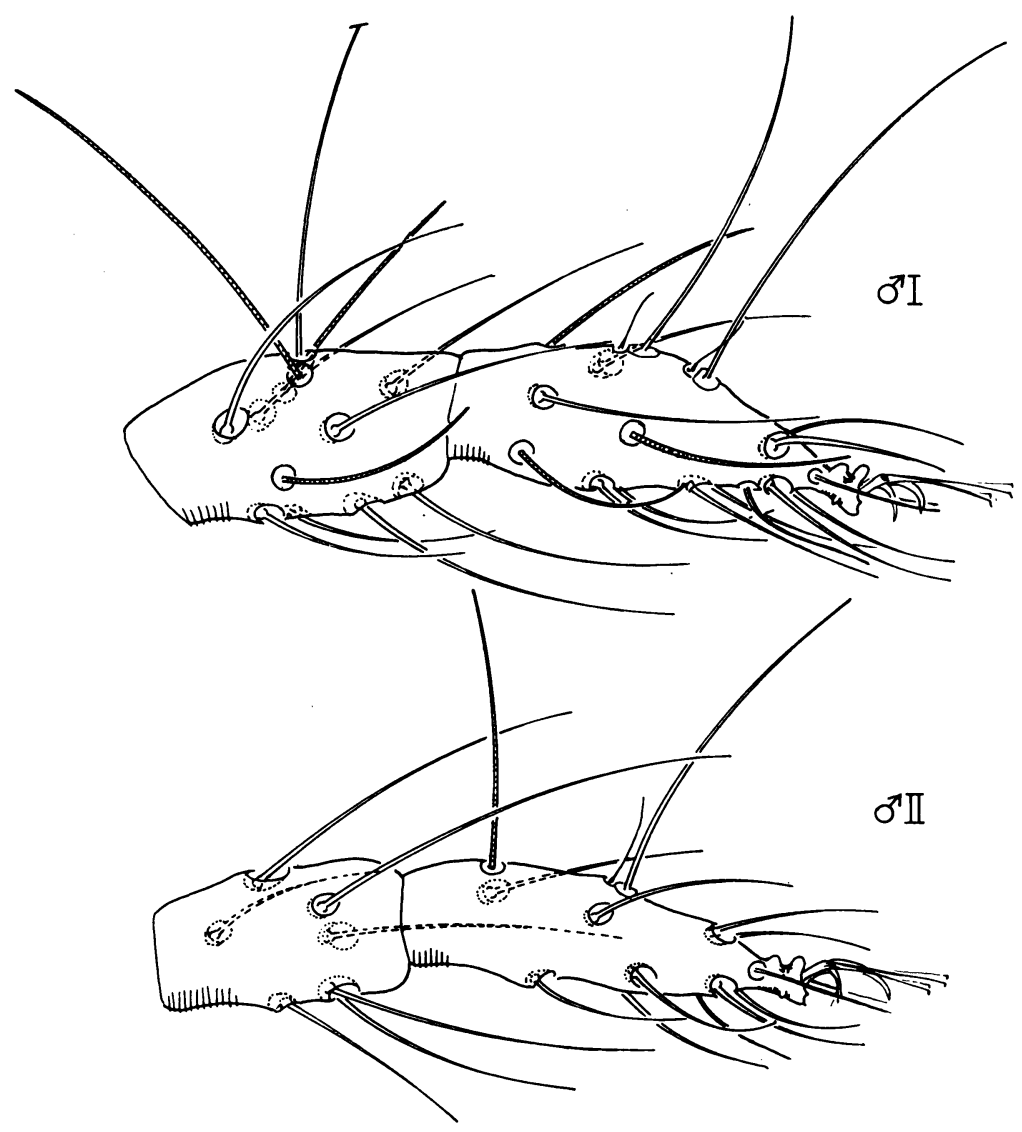

Fig. 61. Oligonychus simus: tibia and tarsus I of male and tibia and tarsus II of male.

Male. Palpus with terminal sensillum stout, a little longer than broad. Peritreme ending in a simple bulb. Tibia I with nine tactile and three sensory setae; tarsus I with four tactile and two sensory setae proximal to duplexes; empodium I with each proximoventral spur as large as dorsal "claw." Tibia II with seven tactile setae; empodium II with proximoventral hairs. Dorsal setae of idiosoma long and slender, serrate. Aedeagus with shaft very broad at base and evenly narrowing to dorsally directed bend, the distal end slightly widened, with an obtuse angulation anteriorly and with a dorsally directed angulation caudally. Length of body $300 \mu$; greatest width of body $160 \mu$.

Female. Palpus with terminal sensillum broader than long. Tibia I with nine tactile and one sensory setae; tarsus I with four tactile setae proximal to duplexes. Tibia II with seven tactile setae. Dorsal integument of hystero- 


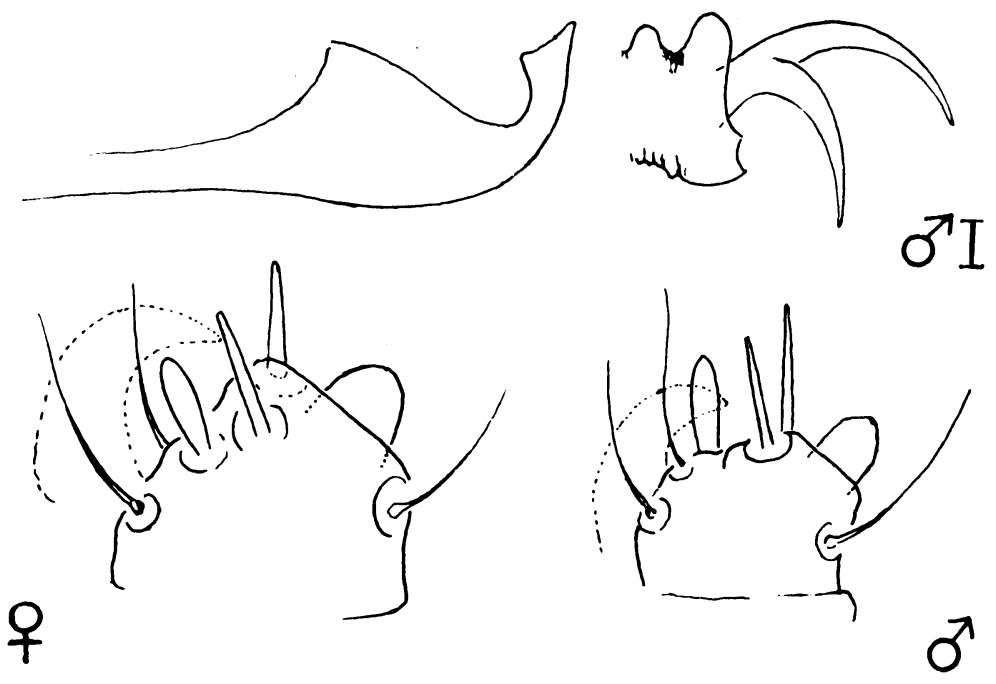

Fig. 62. Oligonychus simus: aedeagus, empodium I of male, terminal segment of palpus of female, and terminal segment of palpus of male.

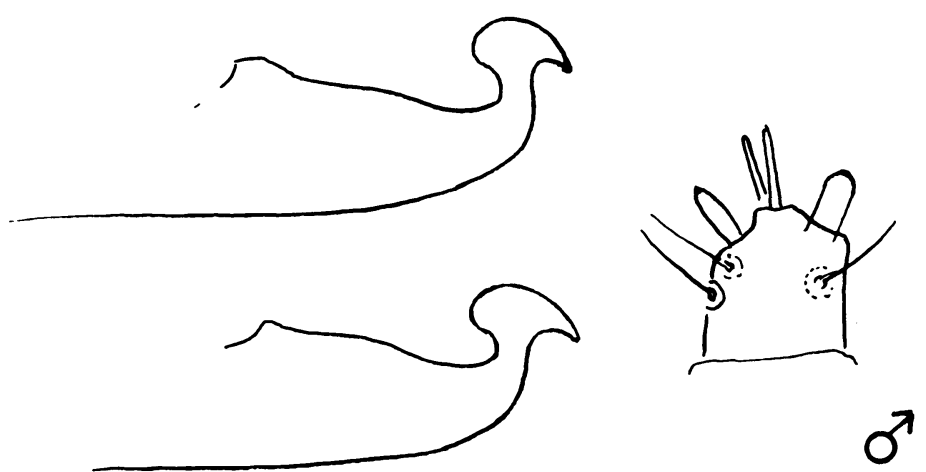

Fig. 63. Oligonychus afrasiaticus: aedeagus and terminal segment of male palpus.

soma with striae lobed and transverse except for longitudinal striae between inner sacrals. Length of body $460 \mu$; greatest width of body $287 \mu$.

Holotype. Female, Zomba, Nyasaland, January, 1930 (C. Smee), on imported sorghum; in the British Museum (Natural History).

Paratypes. Two males, 4 females, Zomba, Nyasaland, January, 1930 (C. Smee), on imported sorghum. 


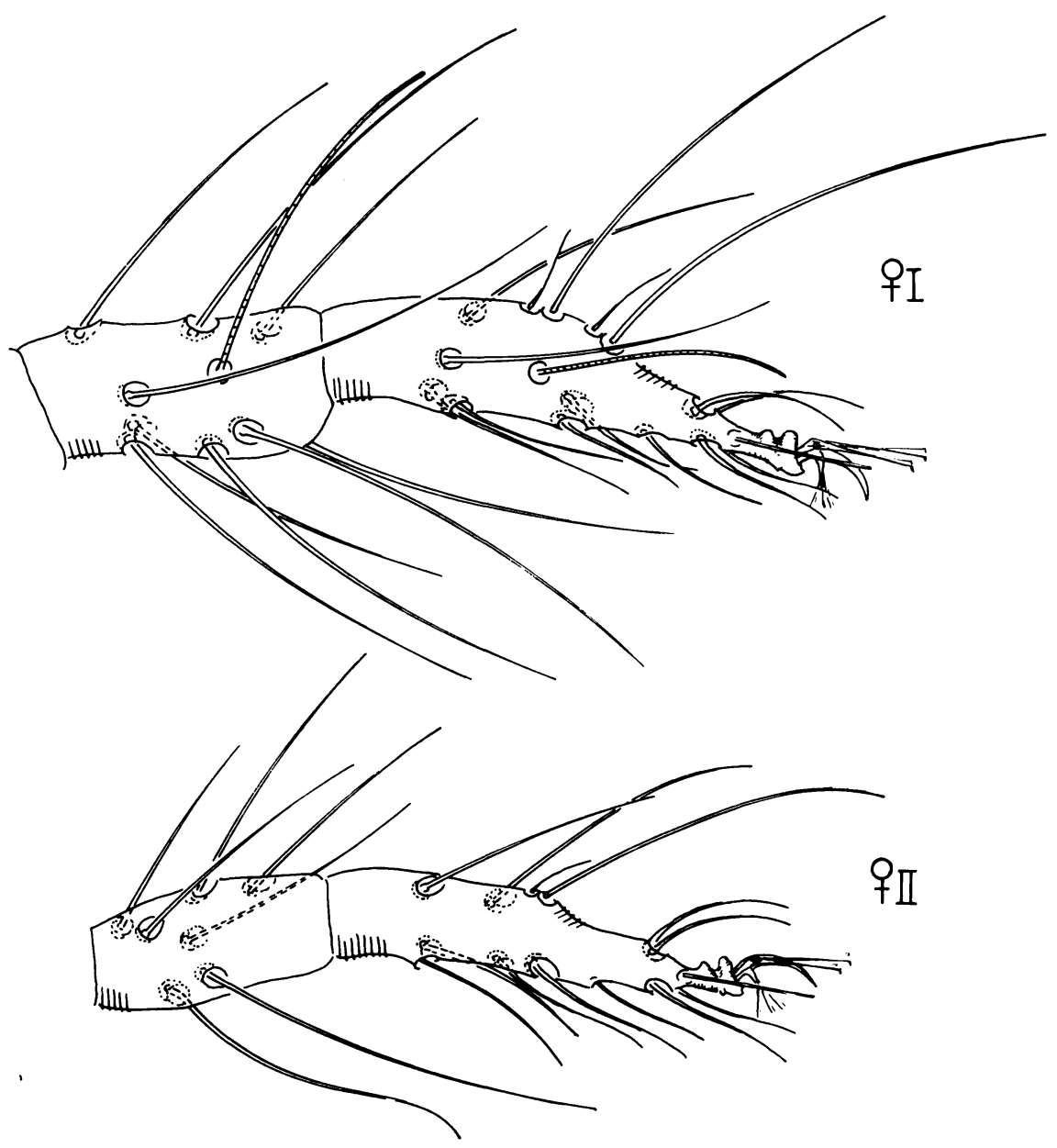

Fig. 64. Oligonychus afrasiaticus: tibia and tarsus I of female and tibia and tarsus II of female.

\section{Oligonychus afrasiaticus (McGregor)}

(Figs. 63, 64, 65)

Oligonychus ?simplex (Banks), Hirst, 1920, Proc. Zool. Soc. Lond. 1920: 60; Buxton, 1921, Bul. Ent. Res. 11: 299. Misidentification.

Paratetranychus simplex (Banks), André, 1932, Bul. Soc. Hist. Nat. Afr. Nord 23: 325 ; André, 1932, Bul. Mus. Natl. Hist. Nat. Paris (sér. 2) 4: 521. Misidentification.

Paratetranychus afrasiaticus McGregor, 1939, Proc. Ent. Soc. Wash. 41: 255 ;

McGregor, 1950, Amer. Midl. Nat. 44: 331. 


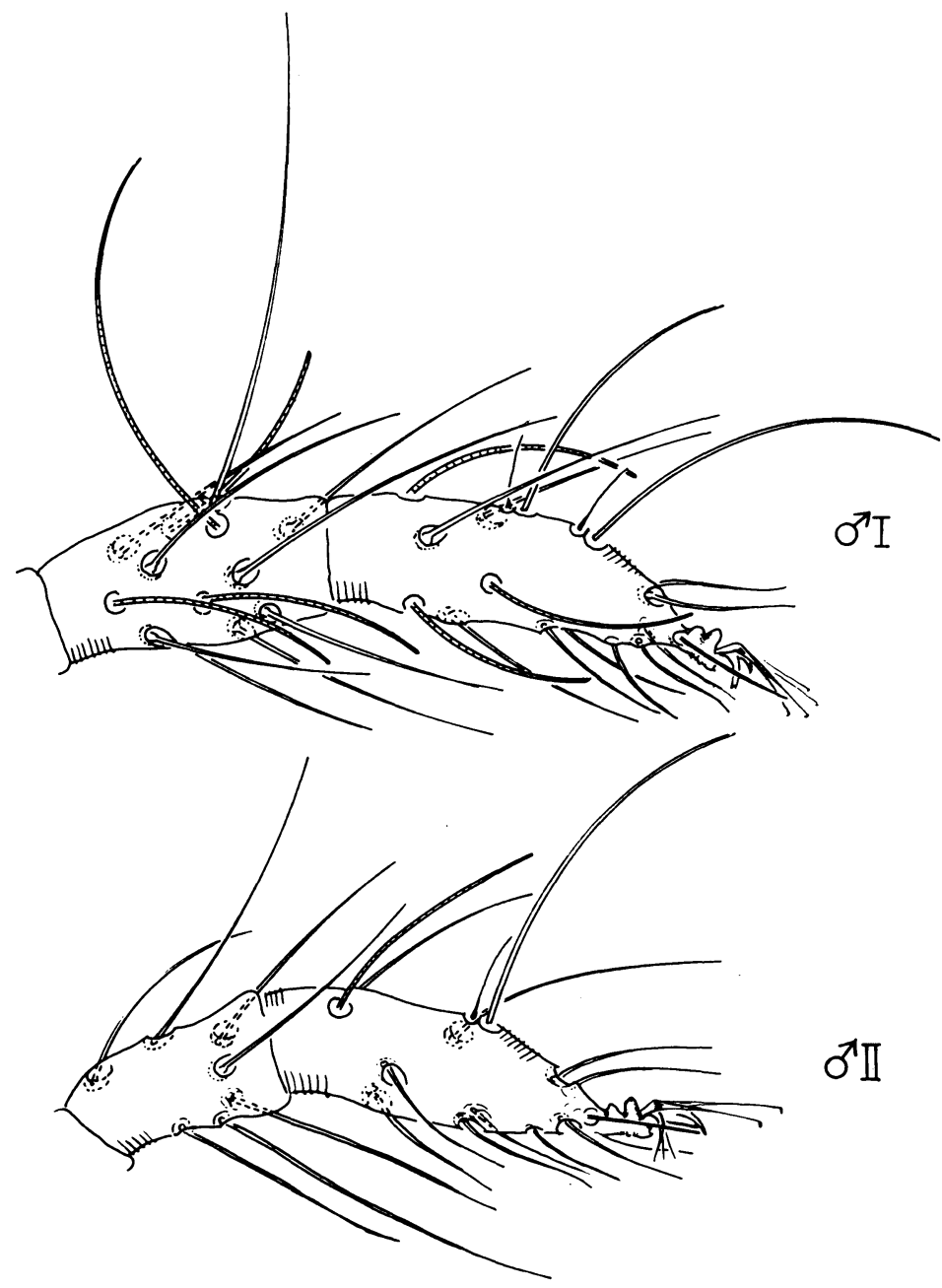

Fig. 65. Oligonychus afrasiaticus: tibia and tarsus I of male and tibia and tarsus II of male.

Oligonychus afrasiaticus (McGregor), Pritchard and Baker, 1955, Mem. Pac. Coast Ent. Soc. 2: 349 .

Oligonychus afrasiaticus is known from North Africa and the Middle East, where it is sometimes a serious pest of dates. It has been recorded from Algeria and Iraq.

Specimens that we have examined, other than the types, are from Gurciloa, Sudan, June 23, 1938 (A. Hassan), on gawa dates; and Umbakol, Sudan, June 25, 1938 (A. Hassan), on gondiela and bitmoda dates. 


\section{Oligonychus tylus, new species}

(Fig. 66)

Oligonychus sp. (in part), Moutia, 1958, Bul. Ent. Res. 49: 60 .

The aedeagus of Oligonychus tylus is similar to that of $O$. modestus (Banks) (eastern United States) in that it has a small distal enlargement. However, the aedeagal knob of tylus bears no anterior angulation.

Male. Palpus with terminal sensillum twice as long as broad. Peritreme straight distally. Tibia I with nine tactile and four sensory setae; tarsus I with four (or three) tactile and three sensory setae proximal to duplexes; empodium I with proximoventral spurs larger than dorsomedian "claw." Tibia II with seven tactile setae; empodium II with proximoventral hairs. Dorsal setae of idiosoma long, slender, serrate. Aedeagus with shaft slightly
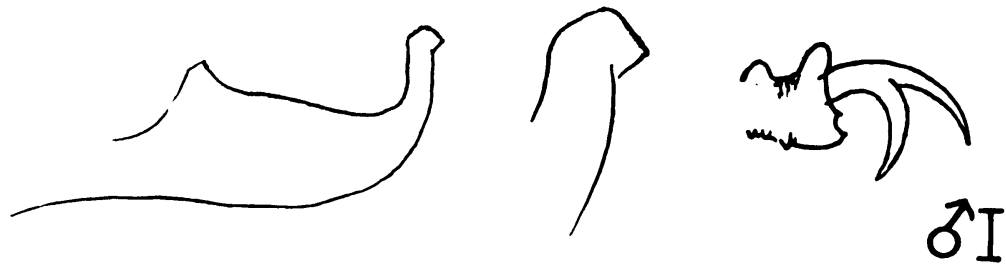

Fig. 66. Oligonychus tylus: aedeagus and empodium I of male.

narrowing to dorsally directed bend, distally with a small enlargement that is obtusely angulate dorsally and acutely angulate caudally. Length of body $306 \mu$.

Female. Palpus with terminal sensillum stout, a little longer than broad. Tibia I with nine tactile and one sensory setae; tarsus I with four tactile and one sensory setae proximal to duplexes. Tibia II with seven tactile setae. Dorsal integument of hysterosoma with lobed striae, transverse except for longitudinal striae between inner sacrals. Length of body $446 \mu$; greatest width of body $255 \mu$.

Holotype. Male, Reduit, Mauritius, January 5, 1955 (L. A. Moutia), on Panicum maximum; in the British Museum (Natural History).

Paratypes. Two males, 6 females, Reduit, Mauritius, January 5, 1955 (L. A. Moutia), on Panicum maximum.

\section{Oligonychus saccharinus, new species}

(Fig. 67)

The distal part of the aedeagus of Oligonychus saccharinus is sigmoid as in O. sacchari (McGregor) (Puerto Rico), but the apex extends well caudad of the caudal margin of the dorsally directed bend.

Male. Palpus with terminal sensillum slender, twice as long as broad. Peritreme ending in a simple bulb. Tibia I with nine tactile and three sensory setae; tarsus I with four tactile and three sensory setae proximal to duplexes; empodium I with proximoventral spurs nearly straight and 
shorter than the "claw." Tibia II with seven tactile setae; empodium II with proximoventral hairs. Dorsal setae of body long and slender, serrate. Aedeagus with shaft narrowing from base, the dorsal bend abrupt, the distal end with an obtuse angulation anteriorly and acutely angulate and curved ventrad at apex. Length of body $224 \mu$; greatest width of body $97 \mu$.

Female. Palpus with terminal sensillum less than twice as long as broad. Tibia I with nine tactile and one sensory setae proximal to duplexes; tarsus I with four tactile and one sensory setae proximal to duplexes. Tibia II with seven tactile setae. Dorsal integument of hysterosoma with lobed striae,

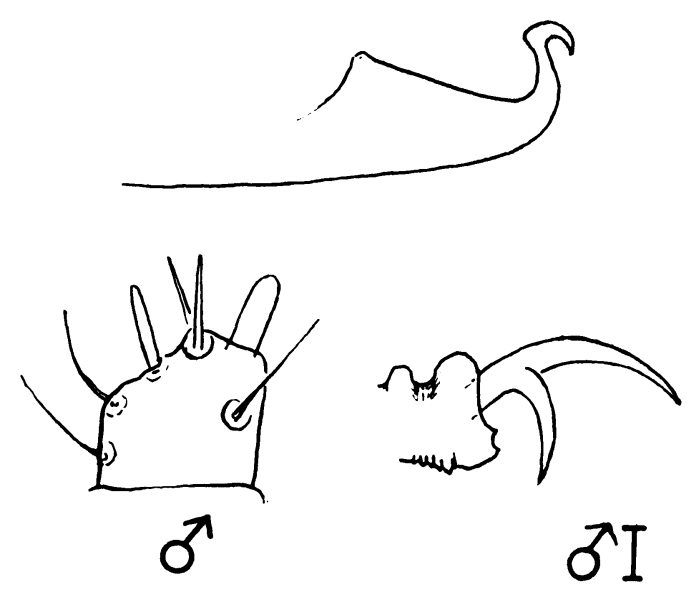

Fig. 67. Oligonychus saccharinus: aedeagus, terminal segment of palpus of male, and male empodium I.

transverse except for longitudinal striae between inner sacrals. Length of body $360 \mu$.

Holotype. Male, Reduit, Mauritius, December, 1954, on sugar cane; in the British Museum (Natural History).

Paratypes. One male, 3 females, Reduit, Mauritius, December, 1954, on sugar cane.

\section{Oligonychus grypus, new species}

(Figs. 68, 69)

The aedeagus of Oligonychus grypus resembles that of O. oryzae (Hirst) (India) in that the distal part tapers and bears an obtuse angulation near the middle. However, this distal part is much longer and slenderer than in oryzae.

Male. Palpus with terminal sensillum slender, three times as long as broad. Peritreme ending in a simple bulb. Tibia I with nine tactile and four sensory setae; tarsus I with four tactile and three sensory setae proximal to duplexes; empodium I with proximoventral spurs much shorter than dorsal 


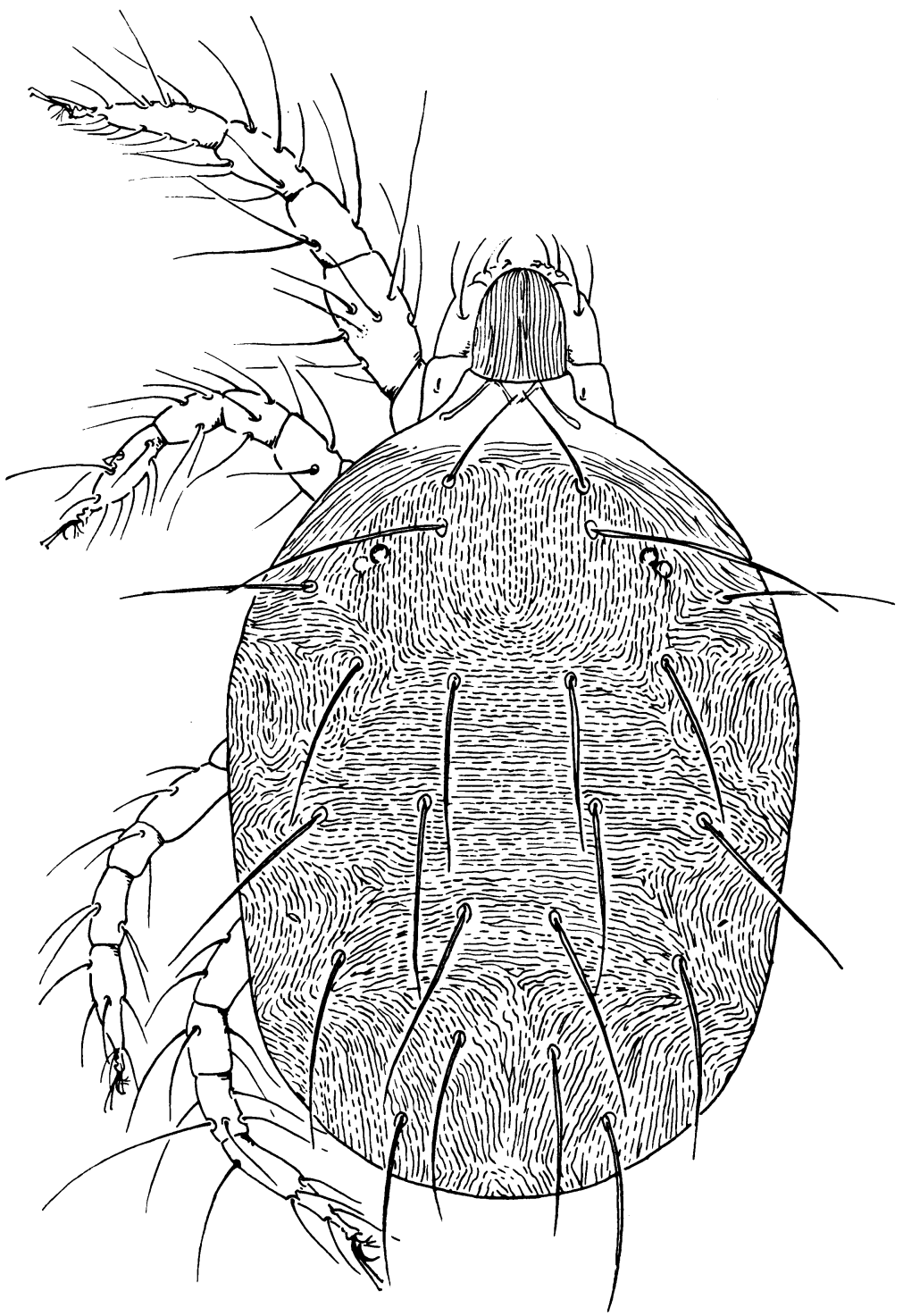

Fig. 68. Oligonychus grypus: dorsal aspect of female.

spur and each with two fine dorsal hairs near apex. Tibia II with seven tactile setae; empodium II with proximoventral hairs. Dorsal setae of idiosoma long and slender, serrate. Aedeagus with shaft narrowing, the dorsally bent portion as long as shaft, tapering, with an obtuse angulation near middle and with the end directed dorsocaudad. Length of body $287 \mu$; greatest width of body $160 \mu$. 
Female. Palpus with terminal sensillum twice as long as broad. Tibia I with nine tactile and one sensory setae; tarsus I with four tactile and one sensory setae proximal to duplexes. Tibia II with seven tactile setae. Dorsal striae of hysterosoma lobed and transverse except for longitudinal striae between inner sacrals. Length of body $465 \mu$; greatest width of body $268 \mu$.

Holotype. Male, Stanleyville, Belgian Congo, April 19, 1955 (E. W. Baker), on sugar cane; type no. 2499 in the U. S. National Museum.

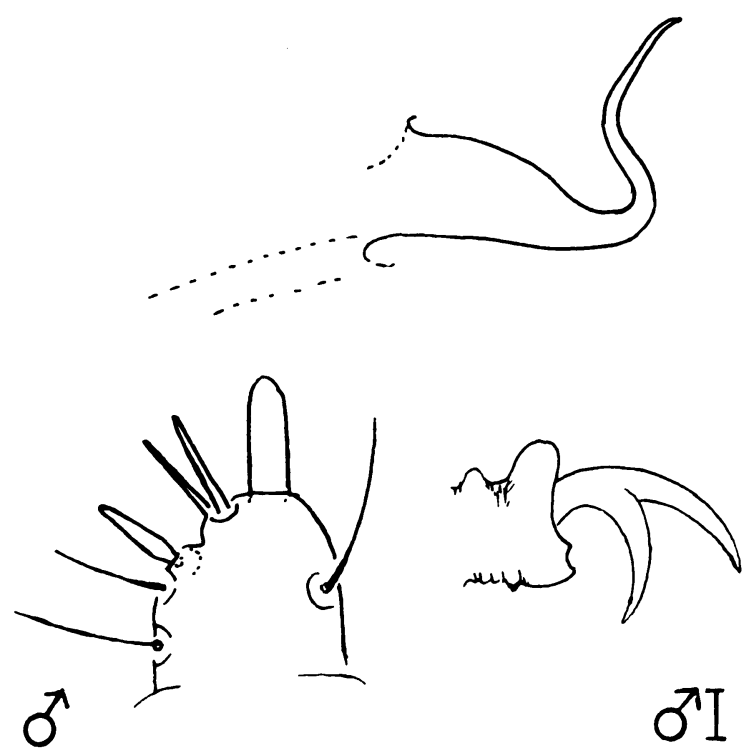

Fig. 69. Oligonychus grypus: aedeagus, terminal segment of male palpus, and empodium I of male.

Paratypes. Thirty-eight males, 58 females, Stanleyville, Belgian Congo, April 19, 1955 (E. W. Baker), on sugar cane; 12 males, 21 females, Leopoldville, Belgian Congo, April 12, 1955 (E. W. Baker), on grass.

\section{Oligonychus plegas, new species}

(Fig. 70)

Oligonychus sp. (in part), Moutia, 1958, Bul. Ent. Res. 49: 60 .

The distal part of the aedeagus of Oligonychus plegas resembles that of o. mexicanus (McGregor) (Mexico) in that it is very shallowly sigmoid, but it is much longer and slenderer.

Male. Palpus with terminal sensillum about twice as long as broad. Peritreme ending in a simple bulb. Tibia I with nine tactile and three sensory setae; tarsus I with four tactile and three sensory setae proximal to duplexes; empodium I with proximoventral spurs much larger than dorso- 
median claw. Tibia II with seven tactile setae; empodium II with short proximoventral spurs. Dorsal setae of body long and slender, pubescent. Aedeagus with shaft narrowing, the dorsally directed part abruptly bent, tapering, slightly sigmoid, and about as long as dorsal margin of shaft. Length of body $287 \mu$; greatest width of body $134 \mu$.

Female. Palpus with terminal sensillum slightly longer than broad. Tibia I with nine tactile and one sensory setae; tarsus I with four tactile and one

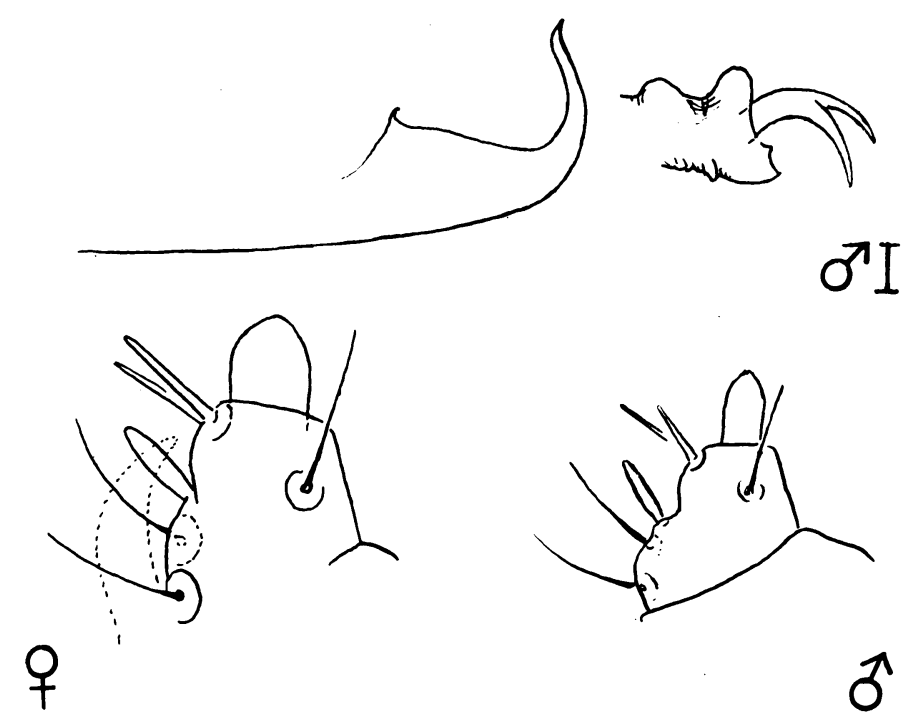

Fig. 70. Oligonychus plegas: aedeagus, empodium I of female, terminal segment of female palpus, and terminal segment of male palpus.

sensory setae proximal to duplexes. Tibia II with seven tactile setae. Dorsal striae of hysterosoma lobed and transverse except for longitudinal striae between inner sacrals. Length of body $395 \mu$; greatest width of body $191 \mu$.

Holotype. Male, Mauritius, January 10, 1956 (L. A. Moutia), on coconut leaves; in the British Museum (Natural History).

Paratypes. Eight males, 10 females, Mauritius, January 10, 1956 (L. A. Moutia), on coconut leaves.

\section{GENUS TETRANYCHUS DUFOUR, 1832}

Tetranychus Dufour, 1832, Ann. Sci. Natl. Paris 25: 276.

African species of the genus Tetranychus may be recognized by having the duplex setae on tarsus I widely separated and the empodium of the female and empodia III and IV of the male consisting of three pairs of similar hairs above which a small empodial claw may be developed. Females 
of the tropical species are carmine or reddish, whereas those of species found in the temperate zones are usually greenish. Nonfeeding or overwintering females are orange. The mites feed on the lower surfaces of leaves of herbaceous plants and trees, and they may spin copious webbing. Their eggs are spherical and without a dorsal stipe.

Tetranychus contains a large number of closely related species, many of which are of economic importance. Both sexes are often necessary for accurate determination, and the phase microscope is invaluable for examination of some of the morphological characters. The lobes on the body "striae" of the female must be seen laterally, preferably at an integumental fold on the slide preparation. Nonfeeding females have only smooth striae.

\section{Key to Species}

1. Peritreme hooked distally ; female hysterosoma with irregular or longitudinal striae between third pair of dorsocentral setae........ 2

- Peritreme straight distally ; female with transverse striae between third pair of dorsocentral hysterosomal setae ............ (1) tumidosus

2. Female with proximal pair of duplex setae more or less in line with proximal tactile setae ..................... 3

- Female with proximal pair of duplex setae well beyond proximal four

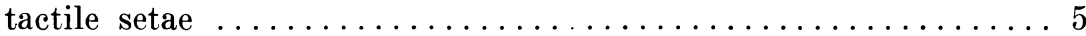

3. Female with small but obvious empodial claw; female podosoma with lobes on medioventral striae; aedeagus with axis of knob parallel to that of shaft; terminal sensillum of male palpus short and stout. . . 4

- Female with empodial claw minute or absent; female podosoma with medioventral striae smooth; aedeagus with axis of knob forming a strong angle with that of shaft; terminal sensillum of male palpus

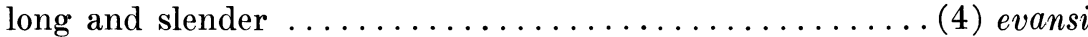

4. Knob of aedeagus with a slender angulation both anteriorly and posteriorly; empodium II of male with proximoventral hairs. . (2) andrei

- Knob of aedeagus with a tiny angulation both anteriorly and posteriorly ; empodium II of male with proximoventral, tridigitate spurs

(3) macfarlanei

5. Female with well developed empodial claw; female metapodosoma with definite lobes on medioventral striae ...............5) sayedi

- Female with empodial claw minute or absent; female metapodosoma without lobes on medioventral striae ................6 6

6. Knob of aedeagus berry-shaped ................ 6) neocaledonicus

- Knob of aedeagus with an angulation $\ldots \ldots \ldots \ldots \ldots \ldots$

7. Aedeagus with knob large, one third as wide as external length of shaft, the anterior development broadly rounded and the posterior angula-

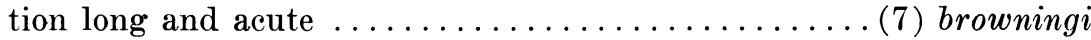

- Aedeagus with knob small, not over one sixth as wide as external length

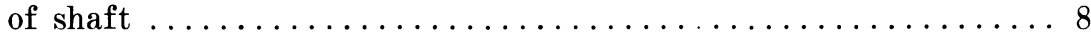


8. Male with empodium I bearing a strong median claw, about two thirds as long as ventral spurs; female with lobes of dorsal integumentary striae of hysterosoma closely placed $\ldots \ldots \ldots \ldots \ldots \ldots \ldots . \ldots$

- Male with empodial claw of tarsus I tiny ; female with tiny, widely spaced lobes ............................. (8) lombardinii

9. Hysterosoma of female with lobes of dorsal integumentary striae all semicircular or triangular; aedeagus with anterior development of knob somewhat rounded, the dorsal margin angulate, and axis of knob forming slight angle with axis of shaft ..........(9) cinnabarinus

- Hysterosoma of female with many of the lobes of the dorsal integumentary striae wide; knob of aedeagus with anterior development acute, the dorsal margin rounded, and its axis parallel to that of shaft

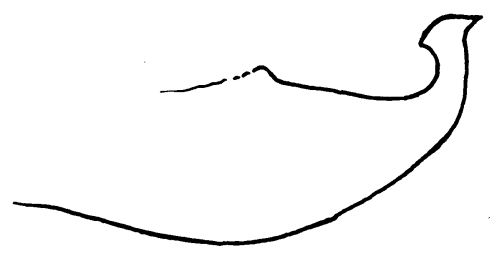

(10) telarius
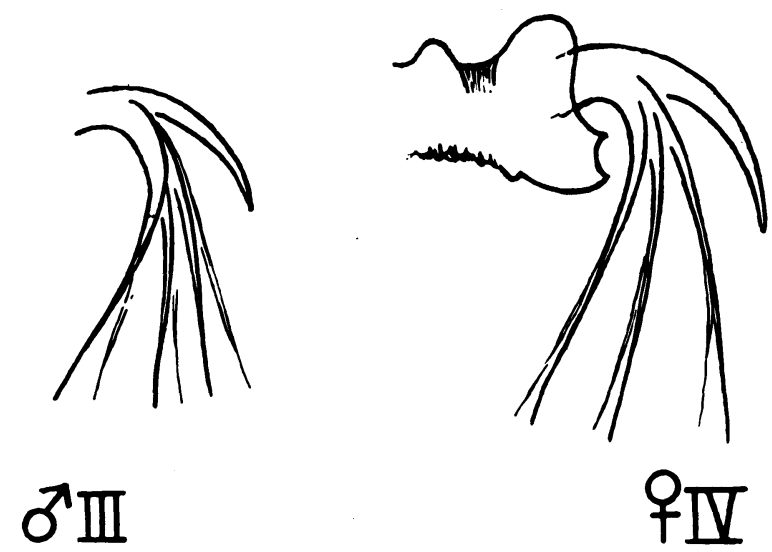

Fig. 71. Tetranychus tumidosus: aedeagus, empodium III of male, and empodium IV of female.

\section{Tetranychus tumidosus, new species}

\section{(Figs. 71, 72, 73)}

Tetranychus tumidosus differs from all other known species of the genus in that the peritreme does not have a distal hook. The female bears transverse striae between the third pair of dorsocentral hysterosomals, and the empodial claw is well developed. The knob of the aedeagus is rather small with anterior and posterior angulations.

Male. Palpus with terminal sensillum very small, about as long as rodlike dorsal seta but wider. Peritreme straight distally, ending in a simple bulb. 


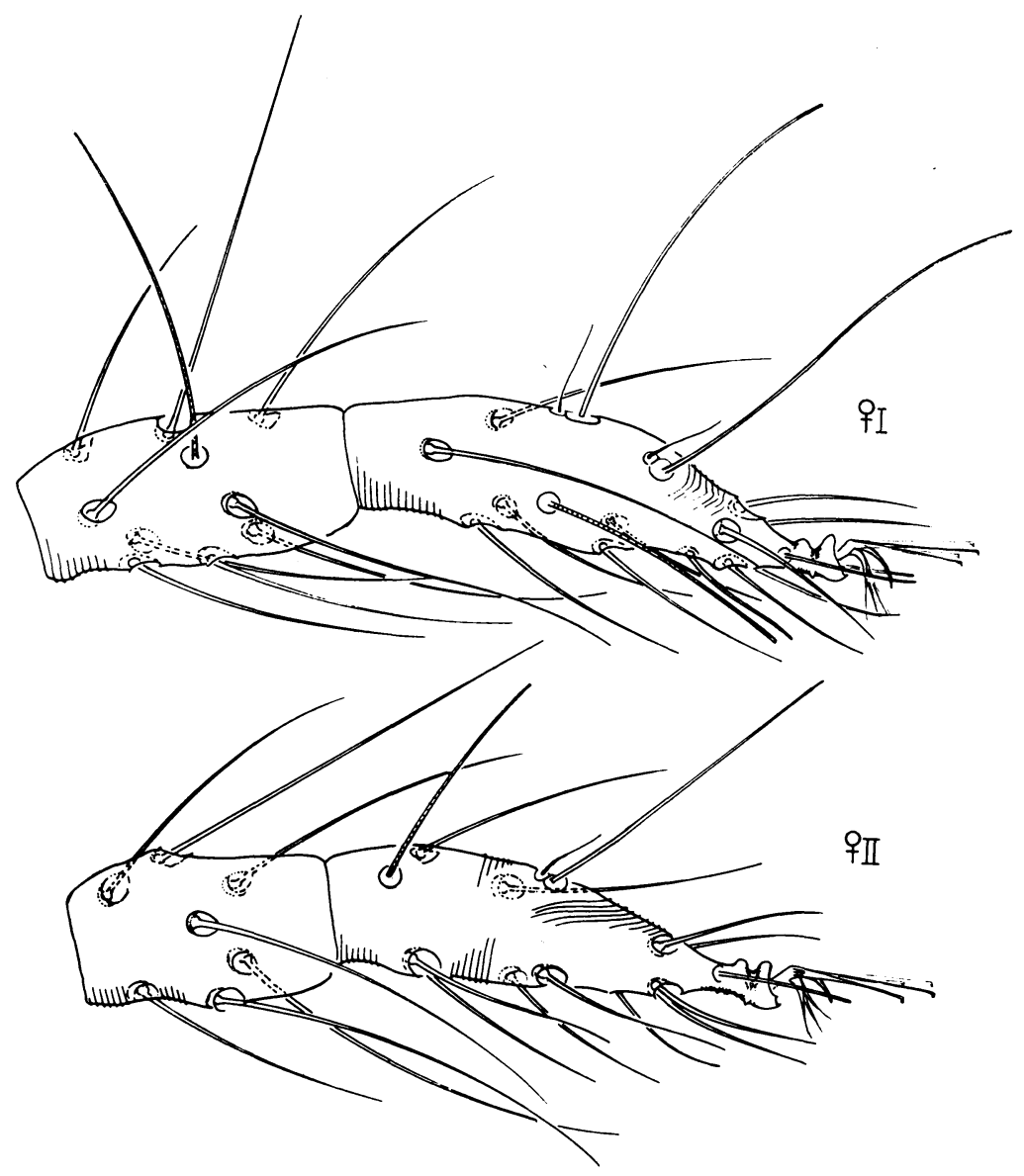

Fig. 72. Tetranychus tumidosus: tibia and tarsus I of female and tibia and tarsus II of female.

Tibia I with nine tactile and four sensory setae; tarsus I with four tactile and two sensory setae proximal to duplexes; empodium I with two clawlike proximoventral spurs and a shorter mediodorsal claw. Tibia II with seven tactile setae; empodium II similar to empodium I. Dorsal setae of idiosoma long, slender, pubescent. Aedeagus with distal knob having an axis at a slight angle to axis of shaft, bearing a small, subacute, anterior angulation and a small, acute posterior angulation. Length of body $382 \mu$.

Female. Palpus with terminal sensillum large, about twice as long as broad. Peritreme with terminal bulb bilobed. Tibia I with nine tactile and one sensory setae; tarsus I with four tactile setae proximal to duplexes. Empodium with dorsal claw a little less than one half as long as the three 


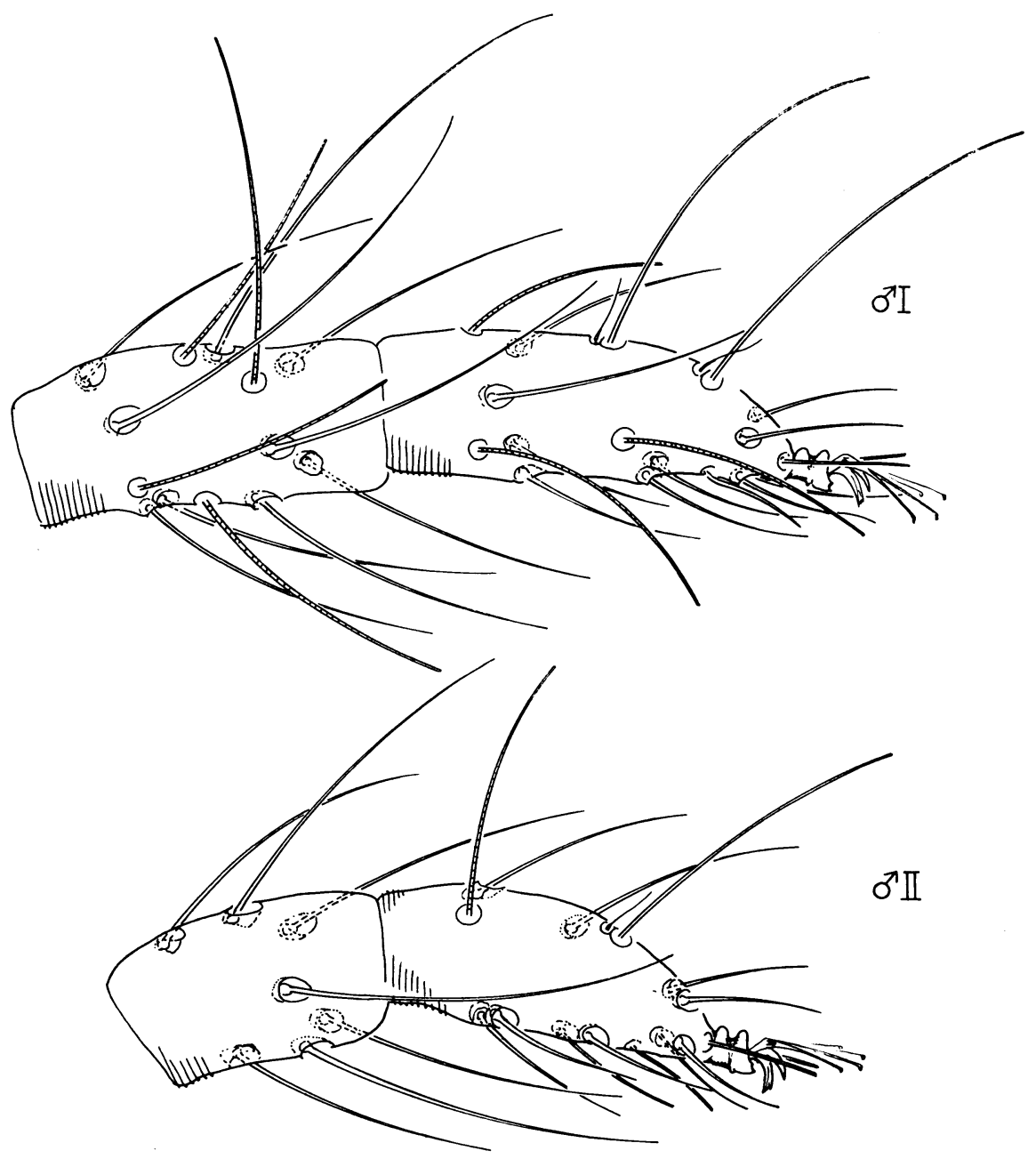

Fig. 73. Tetranychus tumidosus: tibia and tarsus I of male and tibia and tarsus II of male.

pairs of proximoventral hairs. Dorsal striae of idiosomal integument with wide lobes, the hysterosomal striae transverse except for longitudinal striae between inner clunals; medioventral striae of podosoma smooth. Length of body $402 \mu$; greatest width of body $204 \mu$.

Holotype. Male, Metroosberg Mts. (4,000 ft.), South Africa, December, 1917 (R. W. Tucker), on a restionaceous plant; in the British Museum (Natural History).

Paratype. Two males, 3 females, Metroosberg Mts., South Africa, December, 1917 (R. W. Tucker), on a restionaceous plant. 


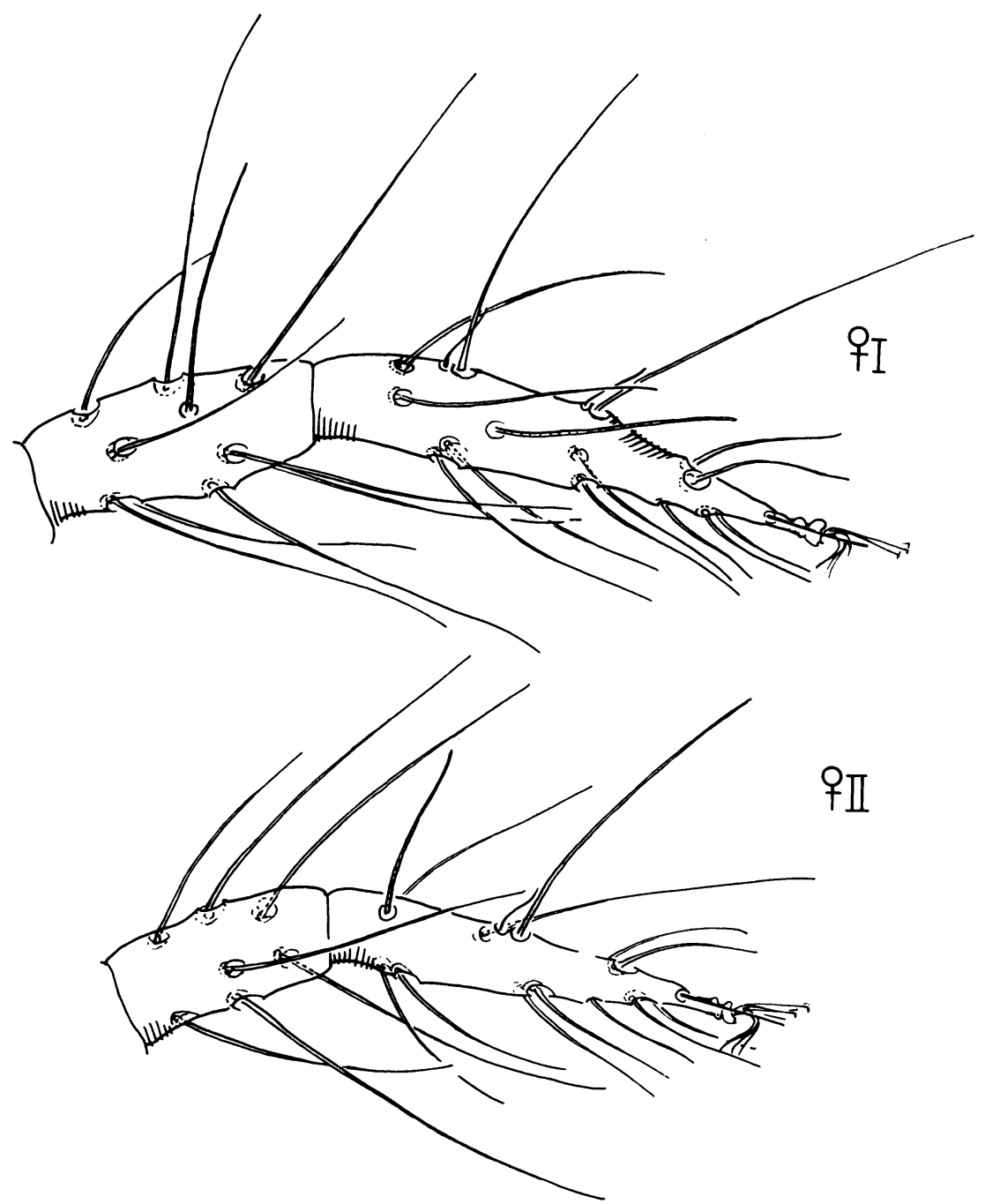

Fig. 74. Tetranychus andrei: tibia and tarsus I of female and tibia and tarsus II of female.

\section{Tetranychus andrei, new species}

(Figs. 74, 75, 76)

The female of Tetranychus andrei has a well-developed empodial claw, and the duplex setae on tarsus I are in line with three of the proximal tactile setae. The knob of the aedeagus has a slender angulation both anteriorly and posteriorly.

Male. Palpus with terminal sensillum stout, about twice as long as broad. 


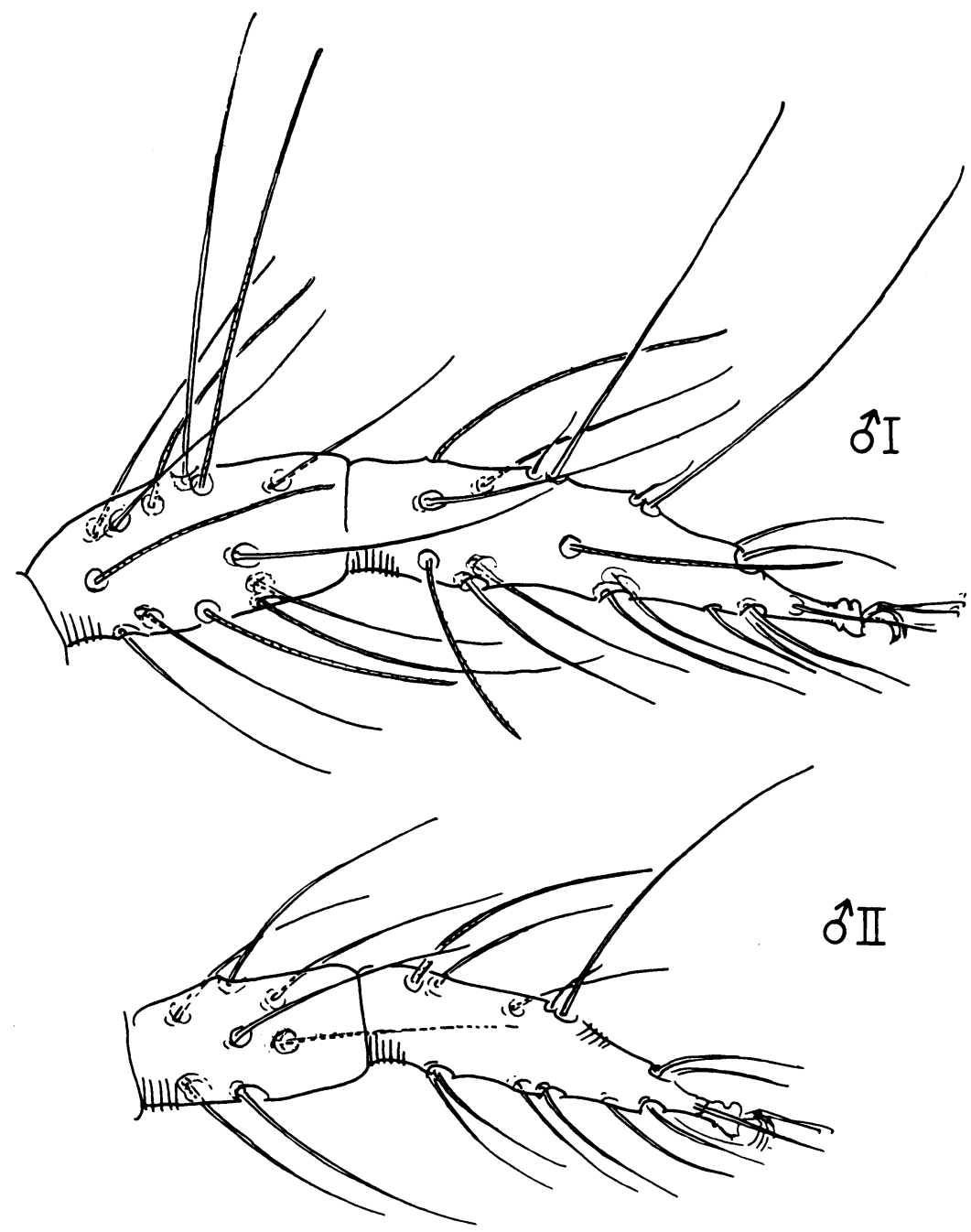

Fig. 75. Tetranychus andrei: tibia and tarsus I of male and tibia and tarsus II of male.

Peritreme with a distal hook. Tibia I with nine tactile and four sensory setae; tarsus I with one tactile and two sensory setae well proximal to duplexes and three tactile setae just proximal to first duplex setae; empodium I with each proximoventral spur slender and tridigitate at tip, the mediodorsal claw shorter. Tibia II with seven tactile setae; empodium II with short mediodorsal claw and three pairs of proximoventral hairs. Dorsal setae of idiosoma long and slender, pubescent. Aedeagus with axis of knob parallel to axis of shaft, bearing an acute angulation anteriorly and a simi- 
lar angulation posteriorly. Length of body $338 \mu$; greatest width of body $153 \mu$.

Female. Palpus with terminal sensillum short and very broad. Tibia I with nine tactile and one sensory setae; tarsus I with one tactile seta proximal to the duplexes and three tactile setae approximately in line with the proximal pair of duplex setae. Empodium with mediodorsal claw well de-
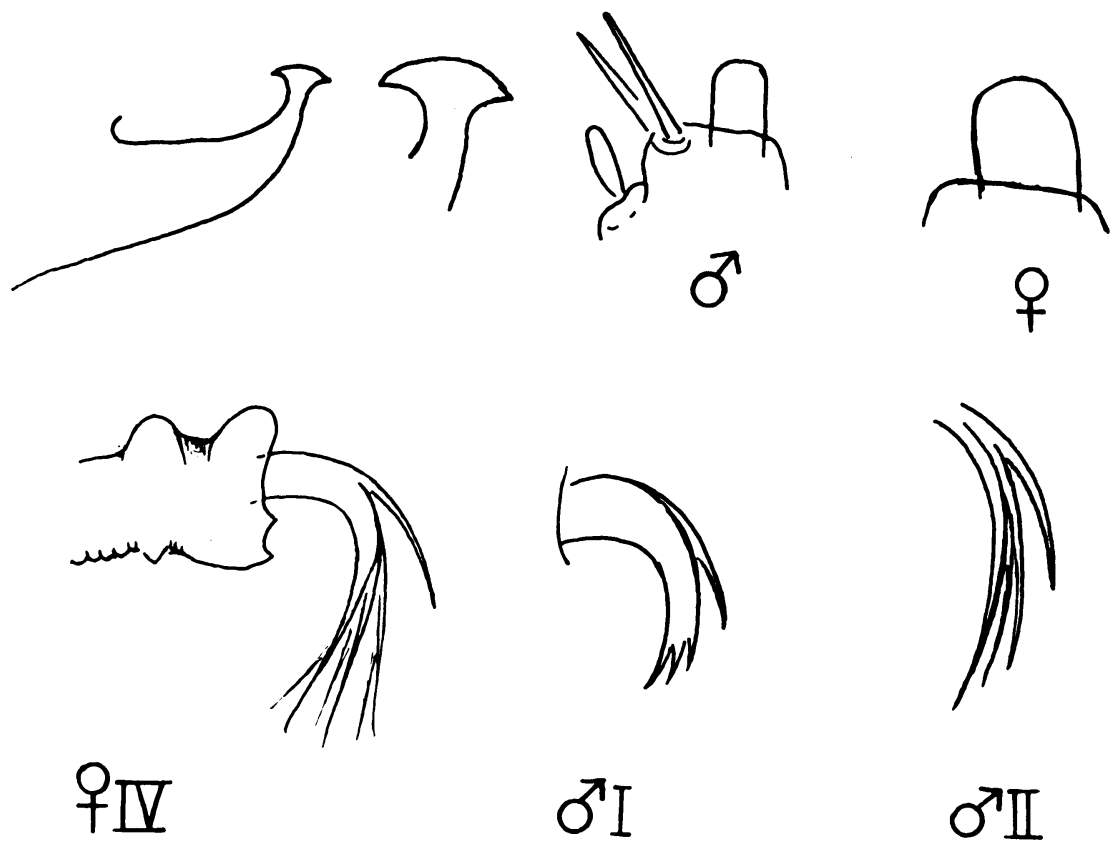

Fig. 76. Tetranychus andrei: aedeagus, terminal sensilla of male and female palpi, empodium IV of female, and empodia I and II of male.

veloped, about one third the length of the three pairs of proximoventral hairs. Dorsal integument of idiosoma with mostly elongate lobes, the hysterosomal striae transverse except irregular between third pair of dorsocentrals and longitudinal between the inner sacrals; medioventral striae of podosoma with wide lobes. Length of body $497 \mu$; greatest width of body $287 \mu$.

Holotype. Male, Leopoldville, Belgian Congo, April 15, 1955 (E. W. Baker), on legume leaf; type no. 2500 in the U. S. National Museum.

Paratypes. One male, 5 females, Leopoldville, Belgian Congo, April 15, 1955 (E. W. Baker), on legume leaf.

This species is named in honor of Dr. Marc André, Ecole des Hautes Etudes, Paris, France. 


\section{Tetranychus macfarlanei, new species}

(Figs. 77, 78, 79)

Tetranychus sp., Moutia, 1958, Bul. Ent. Res. 49: 61.

The female of Tetranychus macfarlanei has the proximal pair of duplex setae on tarsus I in line with three of the proximal tactile setae, and the empodium bears an obvious mediodorsal claw. Empodium II of the male is simlar to empodium I. The dorsally directed bend of the aedeagus is

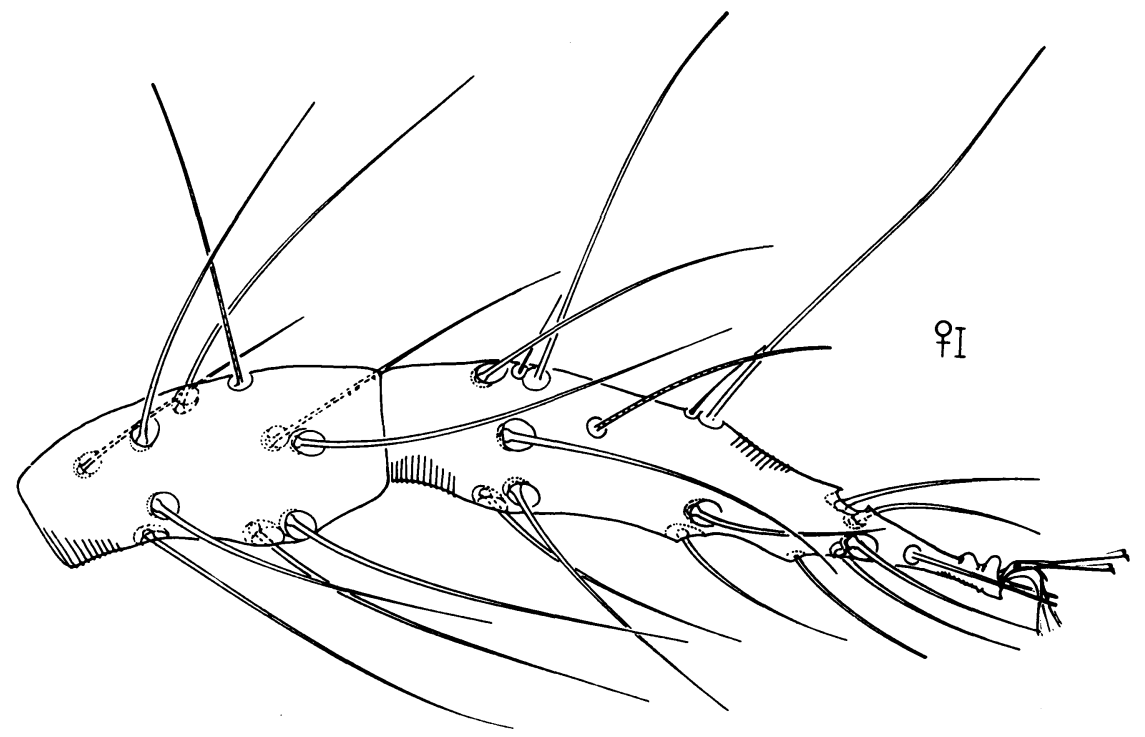

Fig. 77. Tetranychus macfarlanei: tibia and tarsus I of female.

very gentle, and the knob is very small as in T. ludeni (Zacher), but a posterior angulation is present.

Male. Palpus with terminal sensillum stout, about one and one half times as long as broad. Peritreme hooked distally. Tibia I with nine tactile and four sensory setae; tarsus I with two sensory setae well anterior to duplexes and four tactile setae just before proximal pair of duplexes; empodium I with mediodorsal claw much smaller than proximoventral spurs. Tibia II with seven tactile setae; empodium II with mediodorsal claw and proximoventral tridigitate spurs. Dorsal setae of idiosoma long, slender, pubescent. Aedeagus with shaft gradually narrowing, its dorsal margin nearly straight; neck of knob very short, the knob with tiny anterior and posterior angulations and with its axis parallel to that of shaft. Length of body $408 \mu$.

Female. Palpus with terminal sensillum short and very broad. Tibia I with nine tactile and one sensory setae; tarsús I with one tactile seta just 


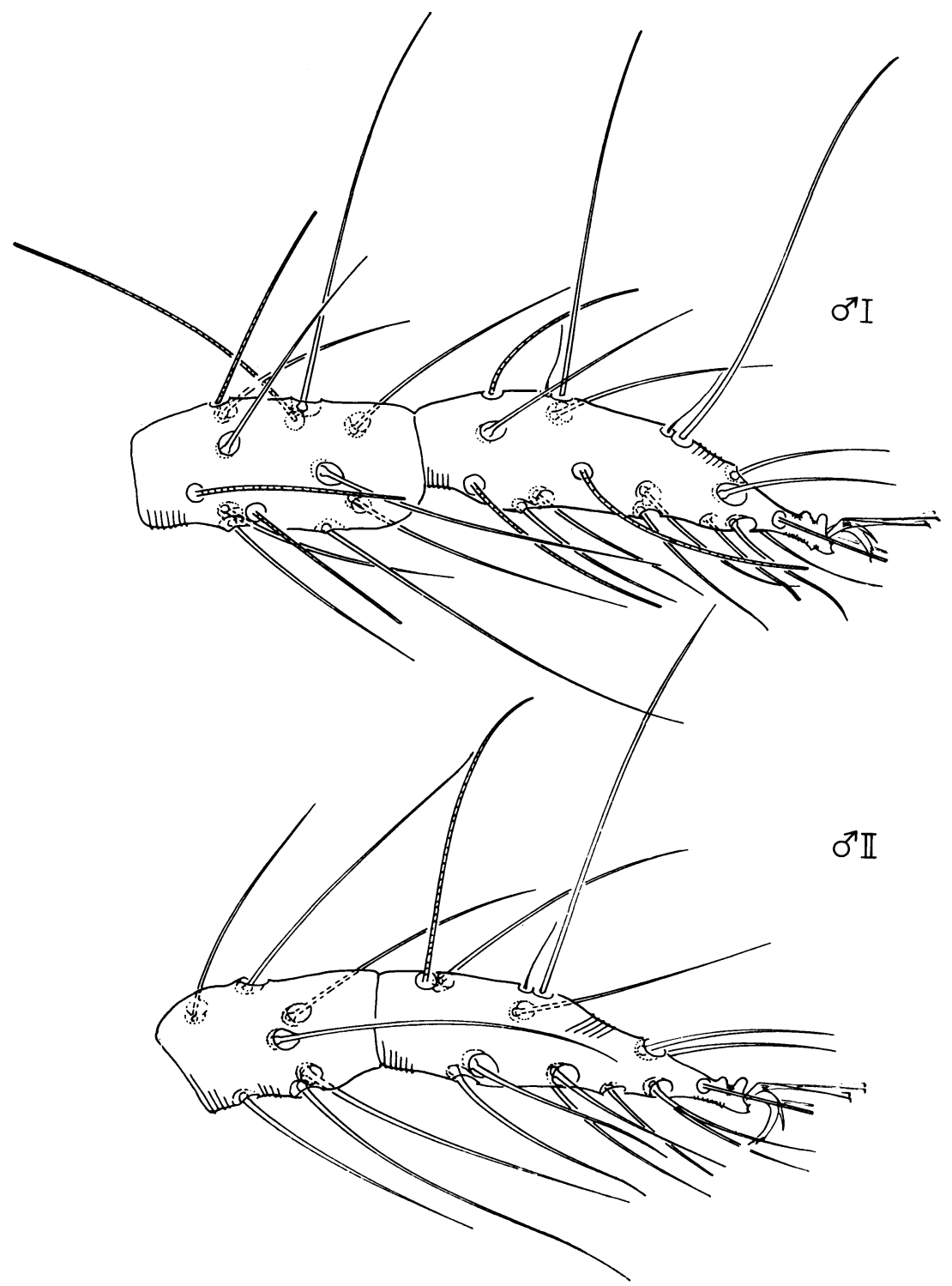

Fig. 78. Tetranychus macfarlanei: tibia and tarsus I of male and tibia and tarsus II of male. 
proximal to and three tactile setae in line with proximal pair of duplexes; empodium I with claw well developed, about one fourth the length of hairs. Dorsal striae of body irregularly longitudinal between third pair of dorsocentrals and inner sacrals, bearing semicircular lobes; podosoma with medioventral striae lobed. Length of body $574 \mu$; greatest width of body $312 \mu$.

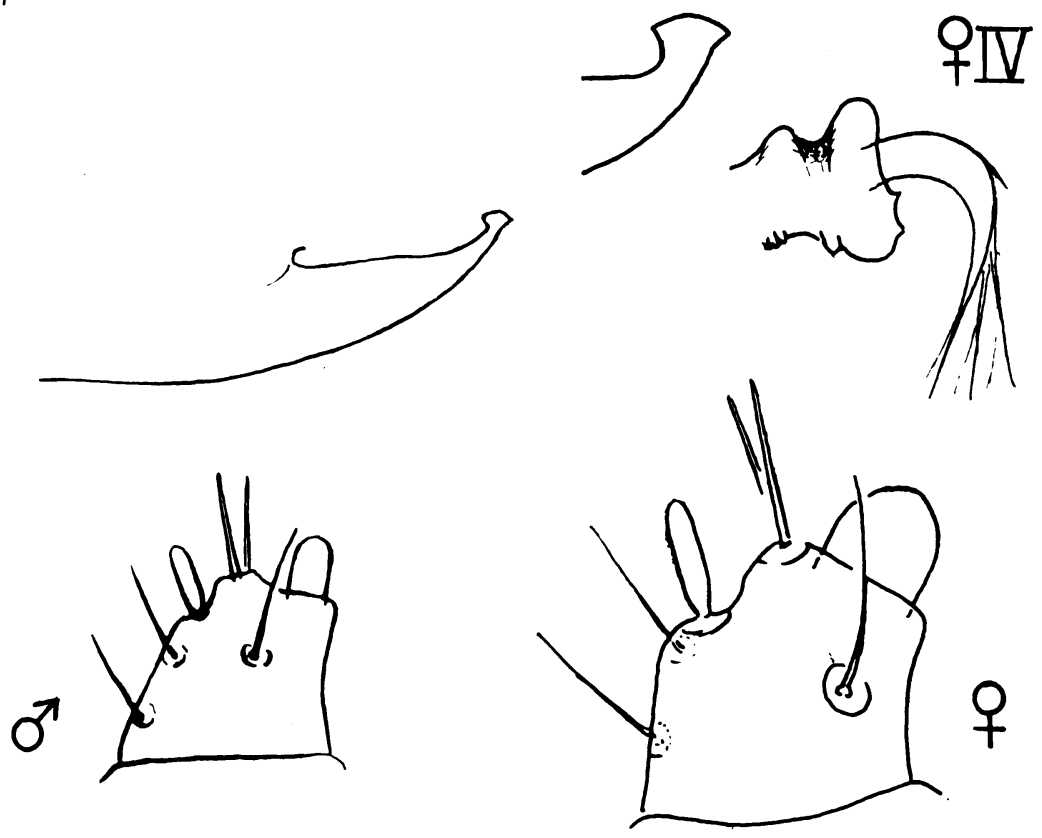

Fig. 79. Tetranychus macfarlanei: aedeagus, empodium IV of female, and terminal segments of palpi of male and female.

Holotype. Male, Belle Vue, Mauritius, May 10, 1955 (L. A. Moutia), on beans and hibiscus; in the British Museum (Natural History).

Paratypes. Four males, Belle Vue, Mauritius, May 10, 1955 (L. A. Moutia), on beans and hibiscus; 8 males, 6 females, Beau Songe, Mauritius, February, 1955 (L. A. Moutia), on hibiscus ; and 3 females, Mauritius, September, 1955 (L. A. Moutia), on pumpkin.

Other collections have been received from Central Farm, Gwalior, India, June 10, 1958 (S. V. Kittur), on okra, gourd, pumpkin, and cucumber.

This species is named in honor of Mr. Donald MacFarlane, British Museum (Natural History). 


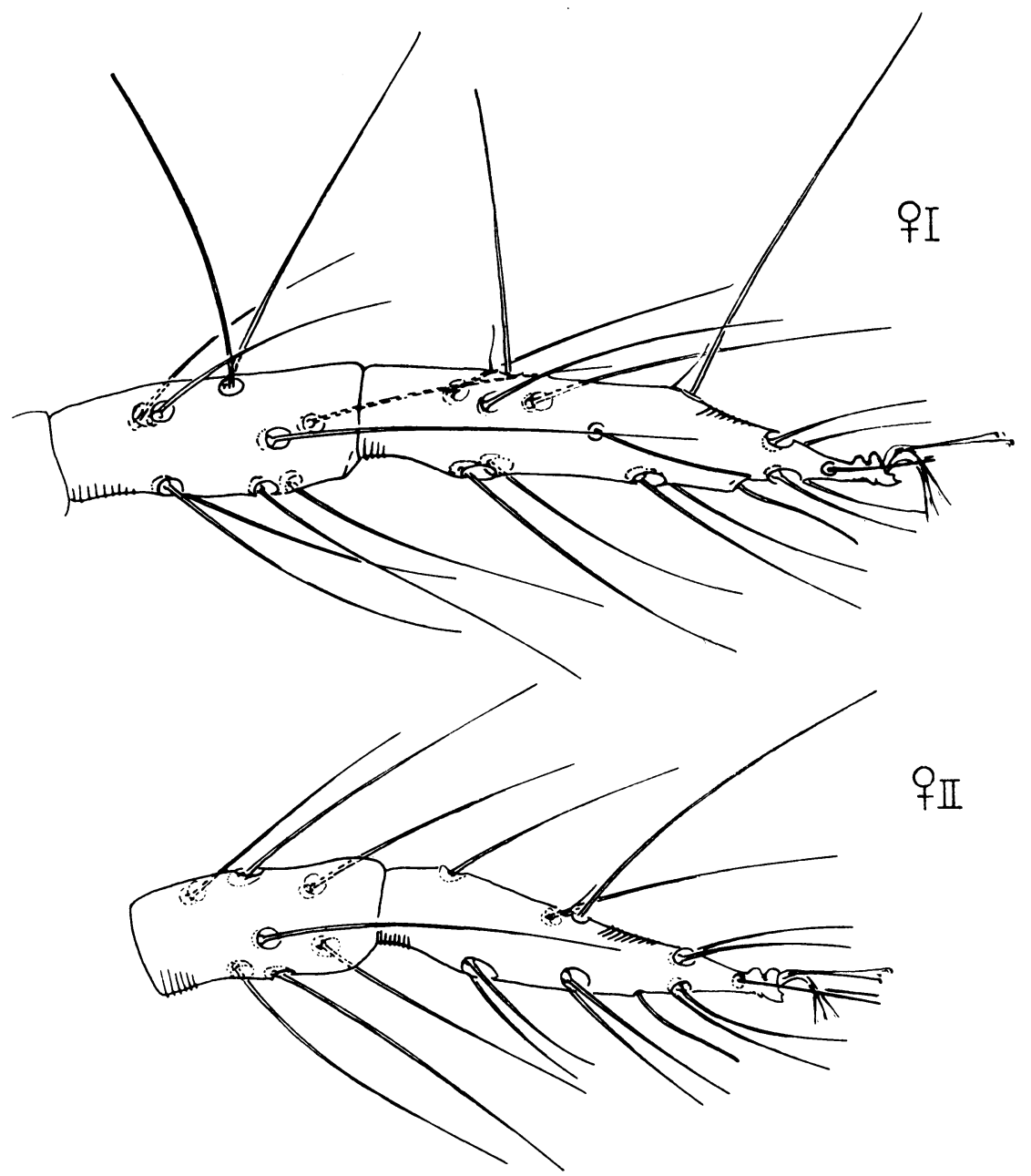

Fig. 80. Tetranychus evansi: tibia and tarsus I of female and tibia and tarsus II of female.

\section{Tetranychus evansi, new species}

(Figs. 80, 81, 82)

Tetranychus marianae (McGregor), Moutia, 1958, Bul. Ent. Res. 49: 61. Misidentification.

The female of Tetranychus evansi has the proximal pair of duplex setae on tarsus I more or less in line with the proximal tactile setae; no empodial 


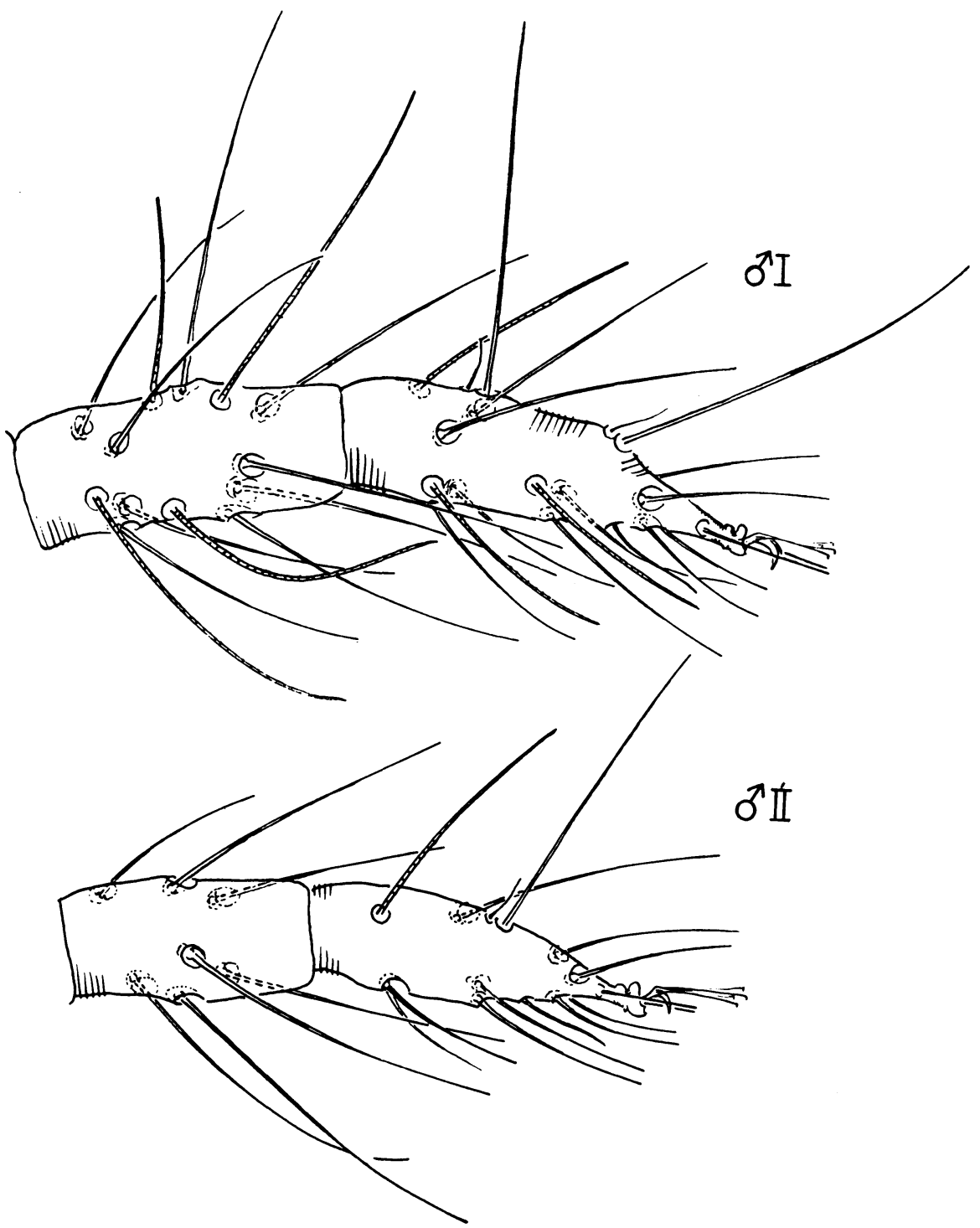

Fig. 81. Tetranychus evansi: tibia and tarsus I of male and tibia and tarsus II of male. 
claw is present. The aedeagus resembles that of T. marianae (McGregor) in that the knob is very small and forms a strong angle with the axis of the shaft; however, empodium II of the male resembles empodium I.

Male. Palpus with terminal sensillum slender, three times as long as broad. Peritreme strongly hooked. Tibia I with nine tactile and four sensory setae; tarsus I with two proximal sensory setae and four tactile setae just proximal to first duplex; empodium I with dorsal claw much smaller than proximoventral spurs. Tibia II with seven tactile setae; empodium II similar to empodium I. Dorsal setae of idiosoma long, slender, pubescent.
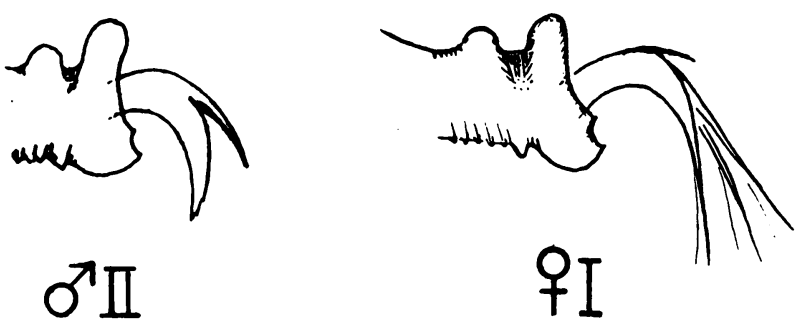

Fig. 82. Tetranychus evansi: aedeagus, empodium II of male, and empodium I of female.

Aedeagus with shaft slender, the knob forming a strong angle with the axis of shaft, very small, with a small anterior angulation and the tip acute and somewhat deflexed. Length of body $400 \mu$; greatest width of body $165 \mu$.

Female. Palpus with terminal sensillum about twice as long as broad. Tibia I with nine tactile and one sensory setae; tarsus I with first pair of duplex setae approximately in line with four tactile setae; empodium I with minute dorsal claw. Hysterosoma with longitudinal striae between third pair of dorsocentrals and inner sacrals, the dorsal striae with semicircular lobes; podosoma with medioventral striae smooth. Length of body $510 \mu$; greatest width of body $287 \mu$.

Holotype. Male, Belle Vue Harel, Mauritius, May 10, 1955 (L. A. Moutia), on tomato; in the British Museum (Natural History).

Paratypes. Five males, 16 females, Belle Vue Harel, Mauritius, May 10, 1955 (L. A. Moutia), on tomato; 3 males, 1 female, Plaine de Papayes, August 11, 1954 (L. A. Moutia), on tomatoes. 
This species is named in honor of Dr. G. Owen Evans, British Museum (Natural History).

\section{Tetranychus sayedi, new species}

(Figs. 83, 84, 85)

The female of Tetranychus sayedi has a well-developed empodial claw ; the duplex setae on tarsus I are distad of the proximal tactile setae, and the

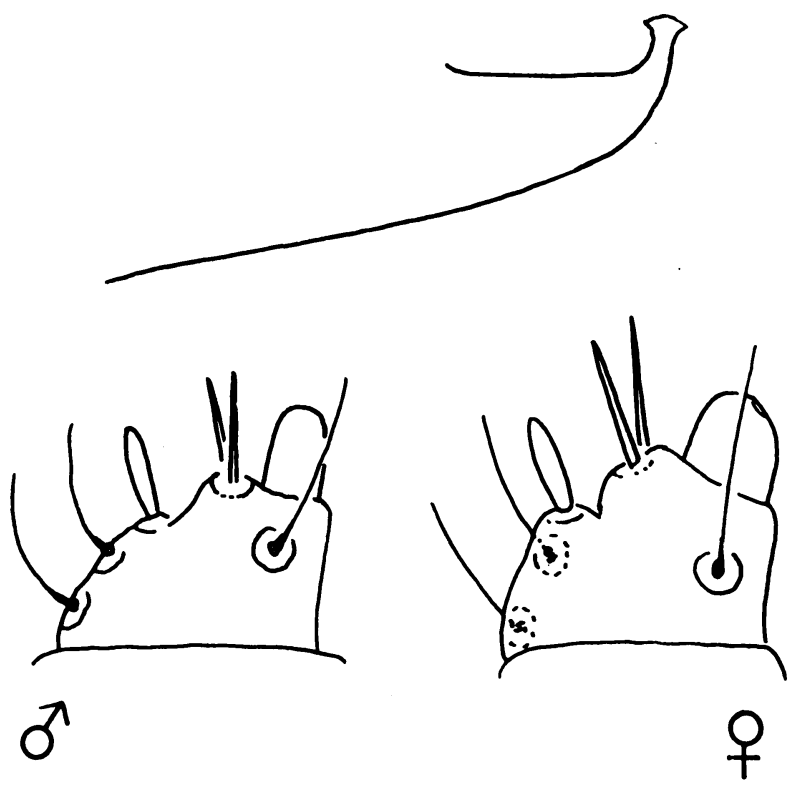

Fig. 83. Tetranychus sayedi: aedeagus, and terminal palpal segments of male and female.

medioventral striae of the podosoma bear lobes. The aedeagus resembles that of T. telarius (Linnaeus) in that the knob is very small, and the anterior and posterior angulations are small and acute.

Male. Palpus with terminal sensillum about twice as long as broad. Peritreme retrorse at distal end. Tibia I with nine tactile and four sensory setae; tarsus I with three tactile and two sensory setae well proximal to duplexes and one tactile seta just proximal to first duplex setae; empodium I with each proximoventral spur short and tridigitate, the mediodorsal claw shorter. Tibia II with seven tactile setae; empodium II a short dorsal claw with three pairs of proximoventral hairs. Dorsum of idiosoma with setae long and slender, pubescent. Aedeagus with axis of knob parallel to that of shaft, rounded dorsally and bearing very small, acute angulations 


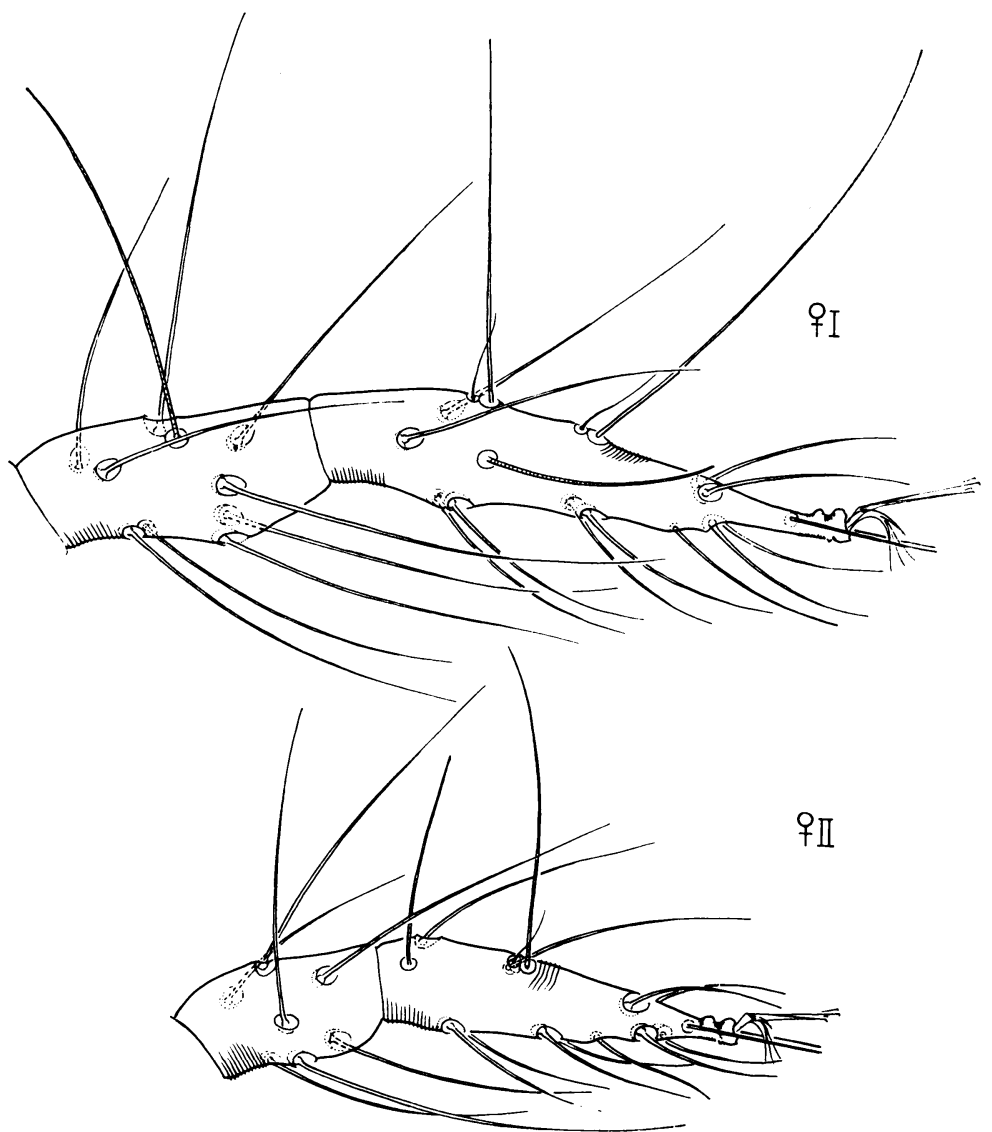

Fig. 84. Tetranychus sayedi: tibia and tarsus I of female and tibia and tarsus II of female.

anteriorly and posteriorly. Length of body $350 \mu$; greatest width of body $172 \mu$.

Female. Palpus with terminal sensillum as broad as long. Tibia I with nine tactile and one sensory setae; tarsus I with three tactile setae well proximal to duplexes and one tactile seta just proximal to first duplex setae. Empodial claw about one fourth the length of proximoventral hairs. Dorsum of idiosoma with striae bearing semicircular lobes, the striae irregular between third pair of dorsocentral hysterosomals and longitudinal between inner sacrals; medioventral striae of metapodosoma with lobes. Length of body $440 \mu$; greatest width of body $274 \mu$.

Holotype. Male. Stanleyville, Belgian Congo, April 19, 1955 (E. W. Baker), on manihot; type no. 2501 in the U. S. National Museum. 


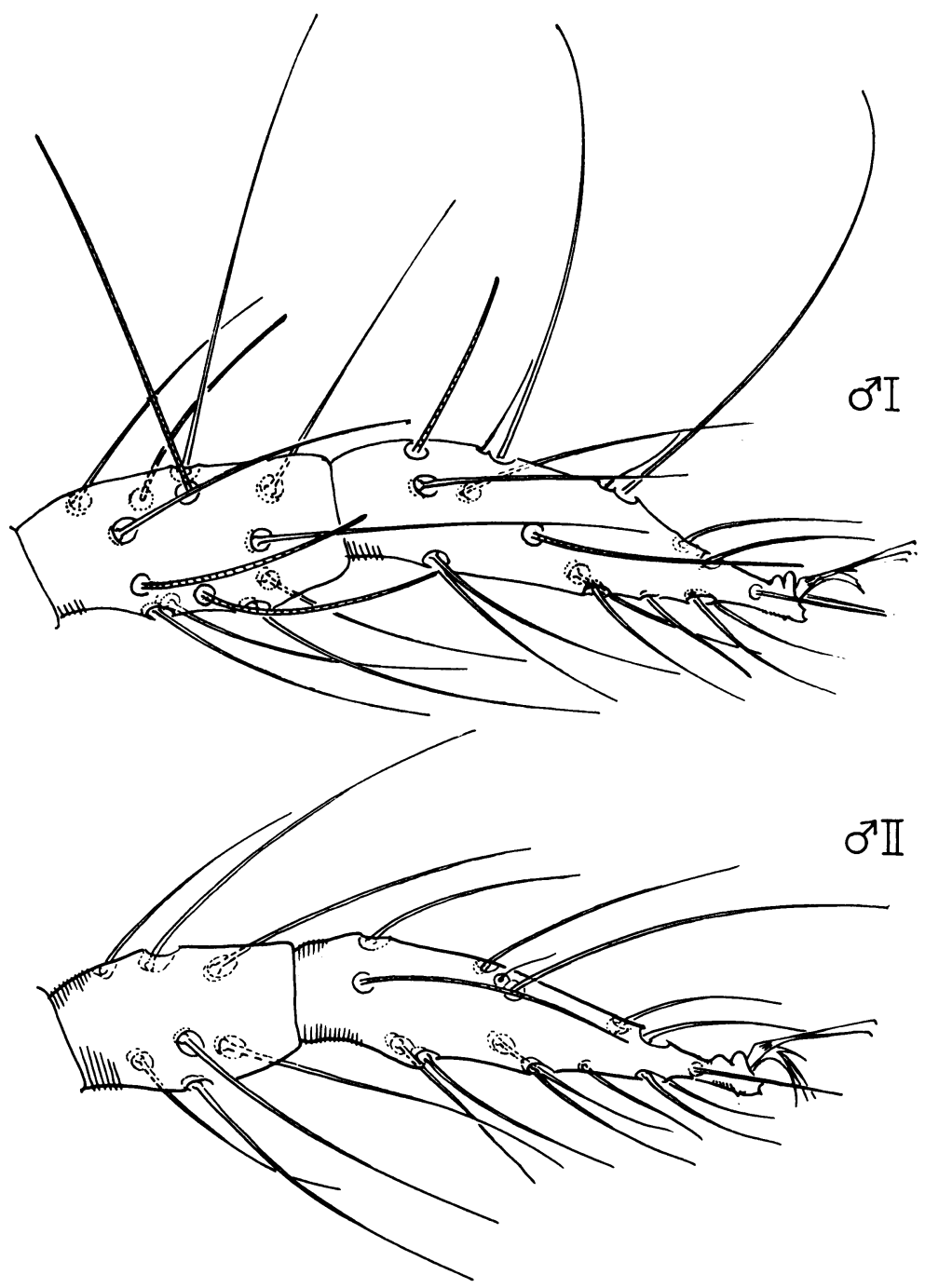

Fig. 85. Tetranychus sayedi: tibia and tarsus I of male, and tibia and tarsus II of male.

Paratypes. Five males, 7 females, Stanleyville, Belgian Congo, April 19, 1955 (E. W. Baker), on manihot.

This species is named in honor of Professor M. T. Sayed, Ibrahim University, Orman-Giza, Egypt. 


\section{Tetranychus neocaledonicus André}

(Figs. 86, 87, 88)

Tetranychus neocaledonicus André, 1933, Bul. Mus. Natl. Hist. Nat. (sér. 2) 5: 302.

Tetranychus cucurbitae Rahman and Sapra, Moutia, 1958, Bul. Ent. Res. 49: 60.

Tetranychus neocaledonicus preoccupies T. cucurbitae, as shown by André (1959). This species is widespread in the tropics. It has been recorded (under

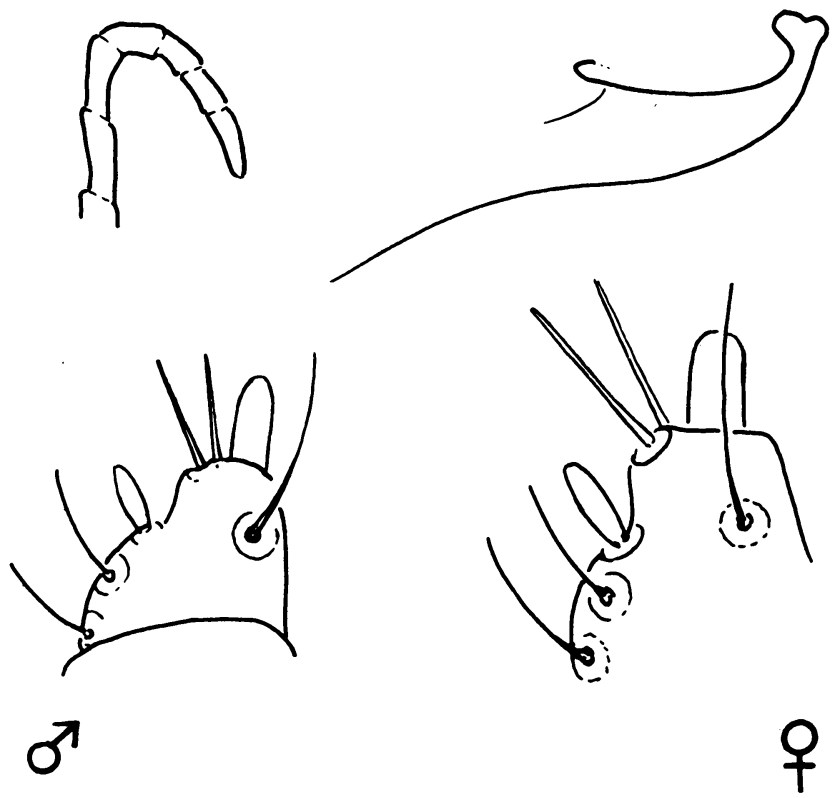

Fig. 86. Tetranychus neocaledonicus: termination of male peritreme, aedeagus, and terminal palpal segments of male and female.

the specific name cucurbitae) from India, Fiji, Hawaii, Venezuela, the southeastern United States, Puerto Rico, the Bahamas, and Mauritius. Rahman and Sapra (1946) list about sixty different kinds of plants as hosts in India.

Moutia (1958) stated that this species may cause damage to peaches in Mauritius, and he noted that coconut is another host. We have studied additional material collected by Mr. Moutia in Mauritius, on Solanum indicum and S. nigrum.

New records from Africa are Nairobi, Kenya, April 2, 1951 (R. LePelley), on Ricinus communis; Salisbury District, Southern Rhodesia, on hydrangea ; Stanleyville, Belgian Congo, April 20, 1955 (E. W. Baker), on Jatropha sp.; and Ruindi Camp, Belgian Congo, May 10, 1955 (E. W. Baker), on Vernonia spp. 


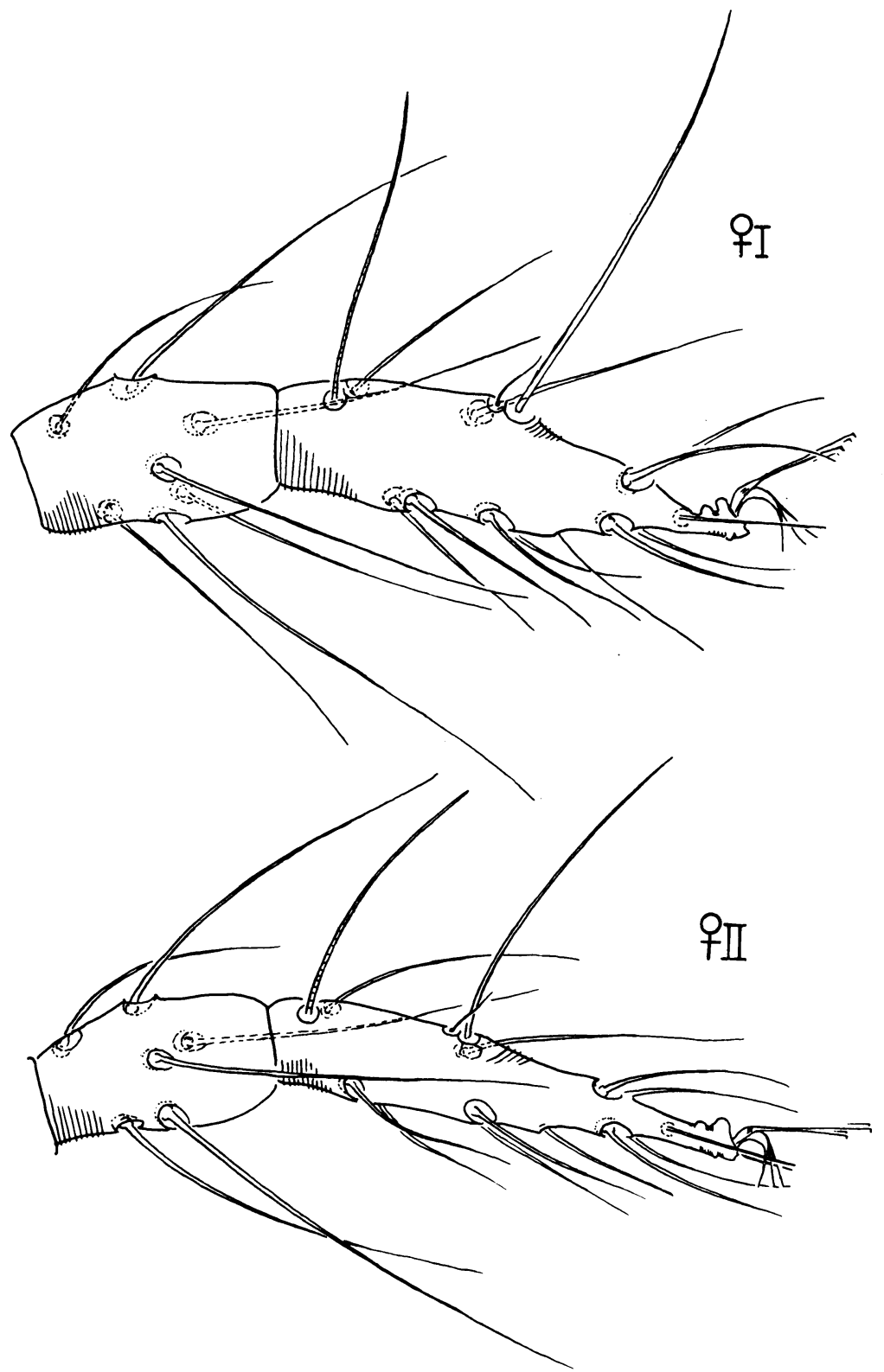

Fig. 87. Tetranychus neocaledonicus: tibia and tarsus I of female and tibia and tarsus II of female. 


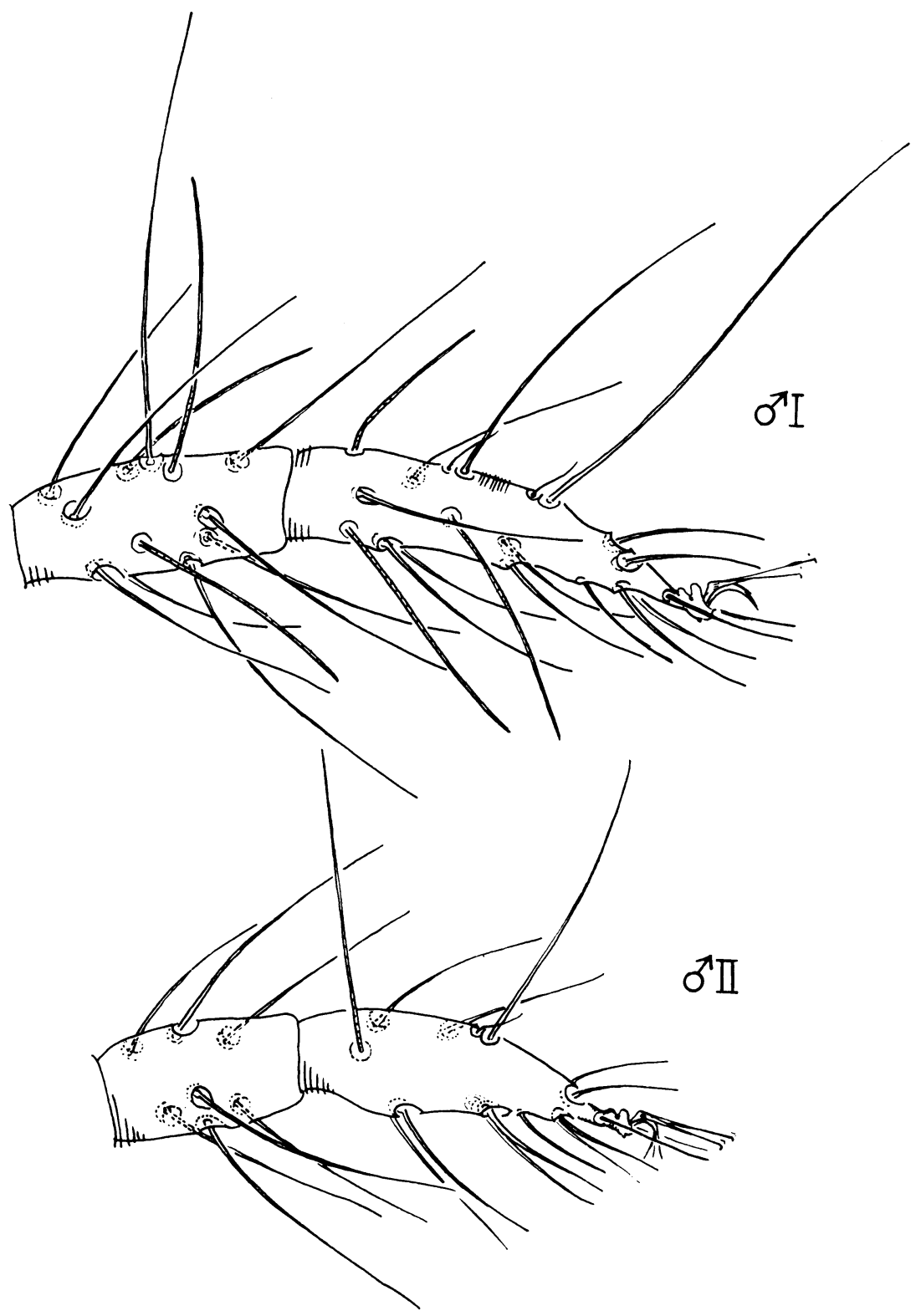

Fig. 88. Tetranychus neocaledonicus: tibia and tarsus I of male and tibia and tarsus II of male. 


\section{Tetranychus browningi, new species}

(Figs. 89, 90)

The female of browningi resembles those of several other species of Tetranychus in that the first pair of duplex setae on tarsus I are placed well beyond the proximal tactile setae, no empodial claw is present, and the striae between the third pair of dorsocentral hysterosomals and the inner sacrals are longitudinal. The male is distinctive among this group of species in having the knob of the aedeagus very large.

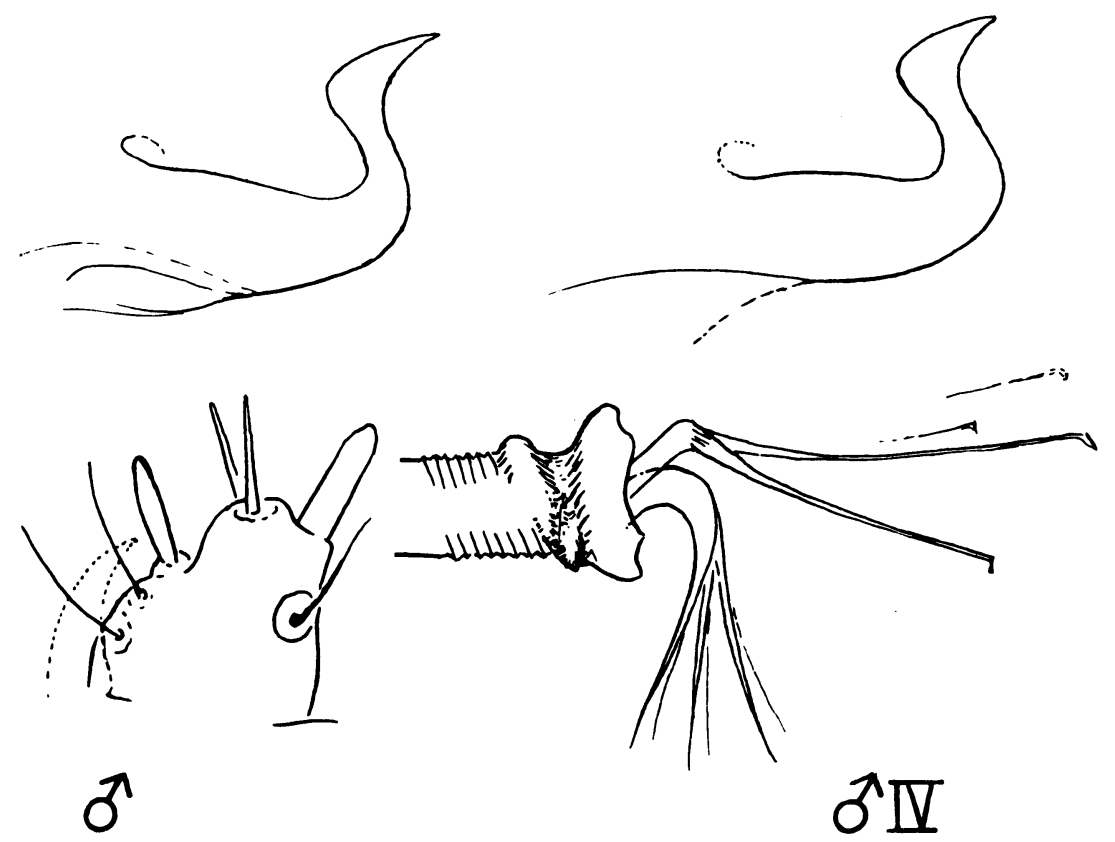

Fig. 89. Tetranychus browningi: aedeagus, terminal segment of male palpus, and empodium IV of male.

Male. Palpus with terminal sensillum slender, four times as long as wide. Peritreme with a strong hook distally. Tibia I with nine tactile and three sensory setae; tarsus I with four tactile and two sensory setae proximal to duplexes; empodium I with dorsal claw very small, the spurs with long teeth. Tibia II with seven tactile setae; empodium II with minute claw and proximoventral hairs. Dorsal setae of idiosoma long and slender, pubescent. Aedeagus with shaft gradually narrowing, the dorsal bend abrupt; knob very large, with axis forming a small angle with that of shaft, with the anterior development broadly rounded and the posterior angulation long and acute at tip. Length of body $319 \mu$; greatest width of body $140 \mu$.

Female. Palpus with terminal sensillum stout, about twice as long as broad. Tibia I with nine tactile and one sensory setae; tarsus I with four 


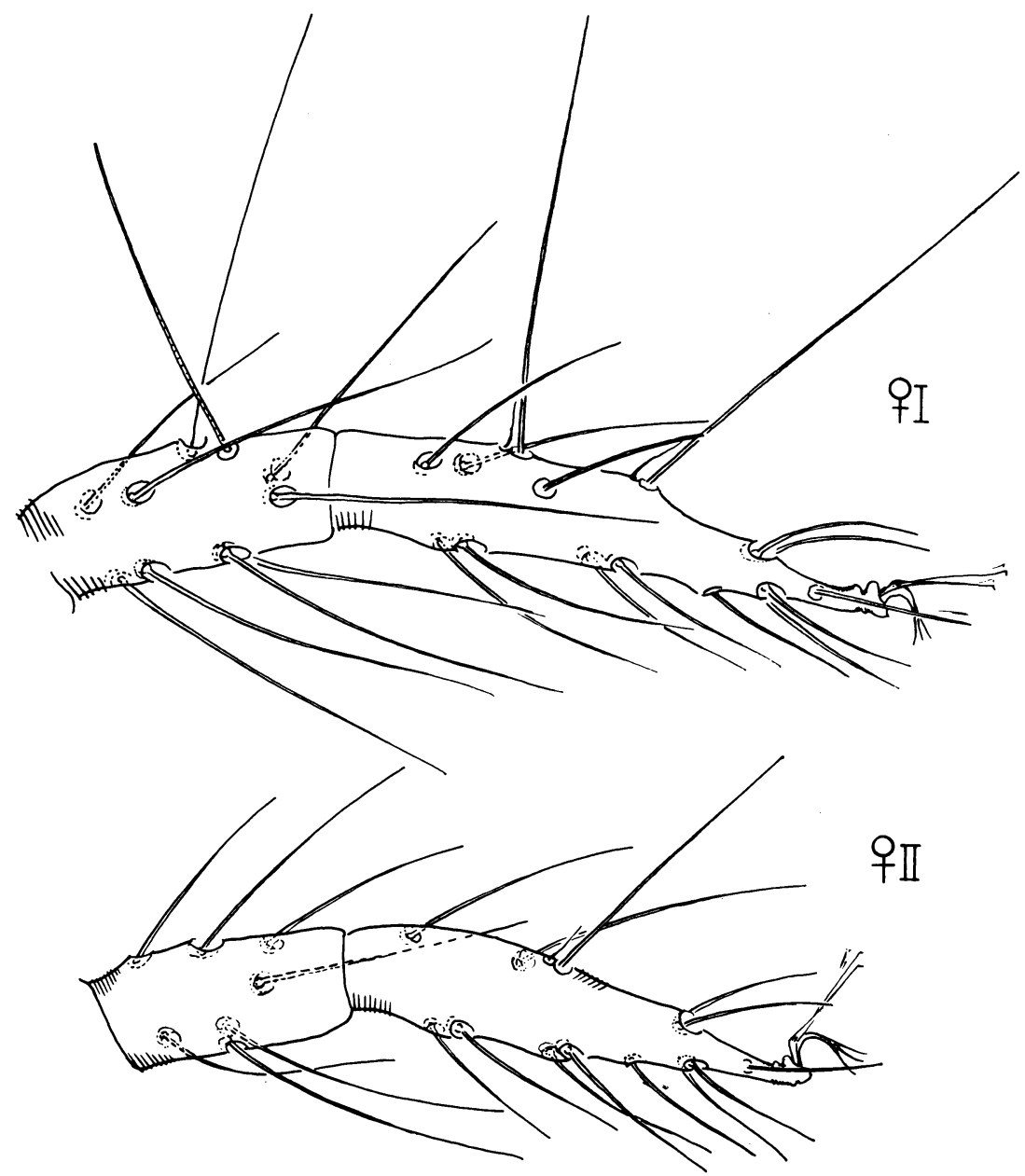

Fig. 90. Tetranychus browningi: tibia and tarsus I of female and tibia and tarsus II of female.

tactile setae well proximal to duplexes. Empodium without mediodorsal claw. Hysterosoma with longitudinal striae between third dorsocentrals and inner sacrals, the striae with tiny, semicircular lobes; podosoma with smooth medioventral striae except for lobes between coxae IV. Length of body $548 \mu$; greatest width of body $306 \mu$.

Holotype. Male, Butembo, Belgian Congo, May 8, 1955 (E. W. Baker), on rose; type no. 2502 in the U. S. National Museum.

Paratypes. Ten males, 35 females, Butembo, Belgian Congo, May 8, 1955 (E. W. Baker), on rose; 5 males, 13 females, INEAC, Mulunga, Belgian Congo, May 18, 1955 (E. W. Baker), on peach.

This species is named in honor of Mr. Francis Browning, British Museum (Natural History). 


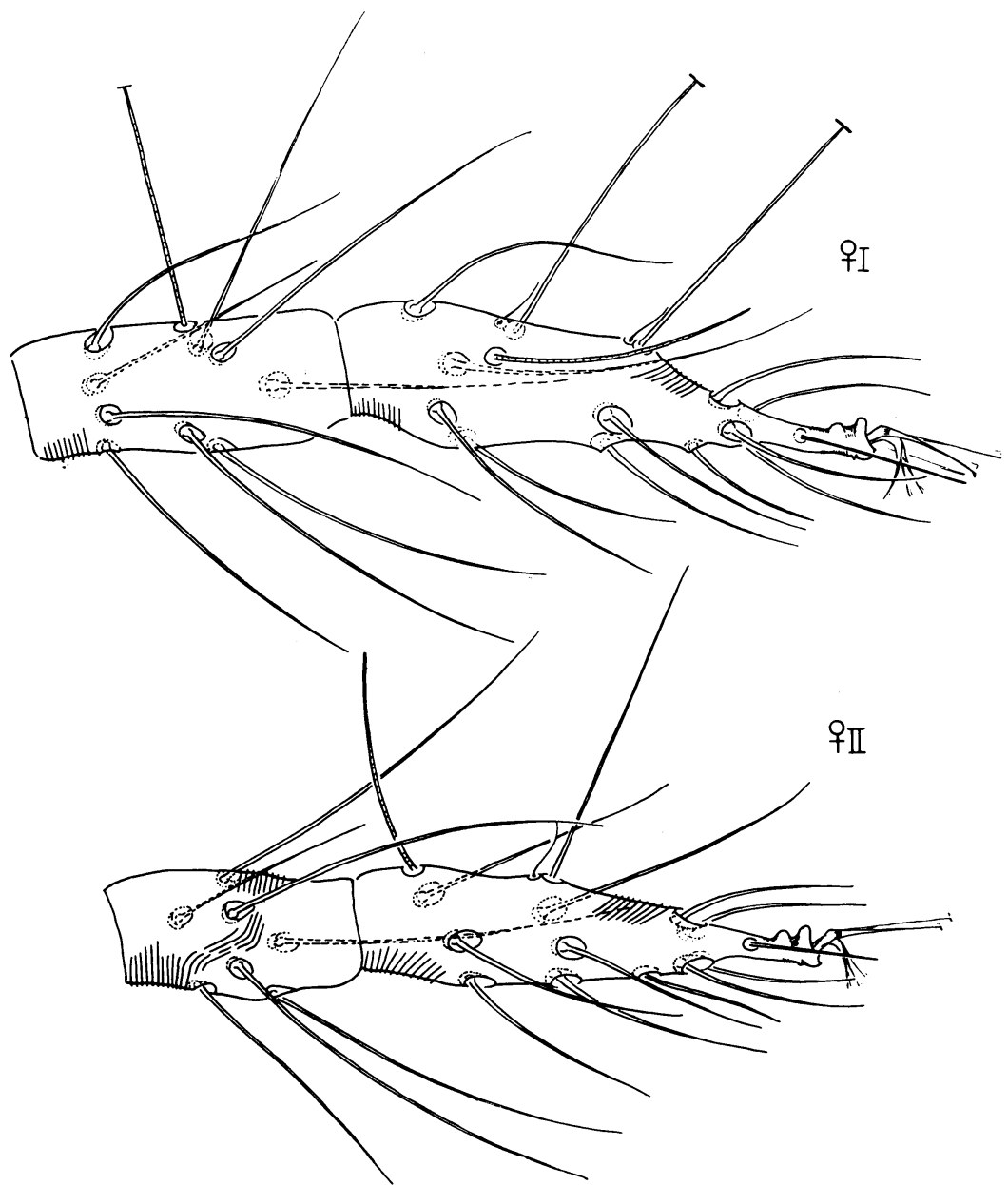

Fig. 91. Tetranychus lombardinii: tibia and tarsus I of female and tibia and tarsus II of female.

\section{Tetranychus lombardinii, new species}

(Figs. 91, 92, 93)

The female of Tetranychus lombardinii resembles that of T. cinnabarinus (Boisduval) except that the lobes of the dorsal striae of the idiosoma are smaller and more widely spaced. The aedeagus of the male resembles that of $T$. cinnabarinus except that the anterior development of the terminal knob is more broadly obtuse. The minute empodial spur on tarsi I and II will distinguish the male from $T$. cinnabarinus, $T$. telarius (Linnaeus), and related species.

Male. Palpus with terminal sensillum slender, four times as long as broad. Peritreme with distal end strongly hooked. Tibia I with nine tactile and 


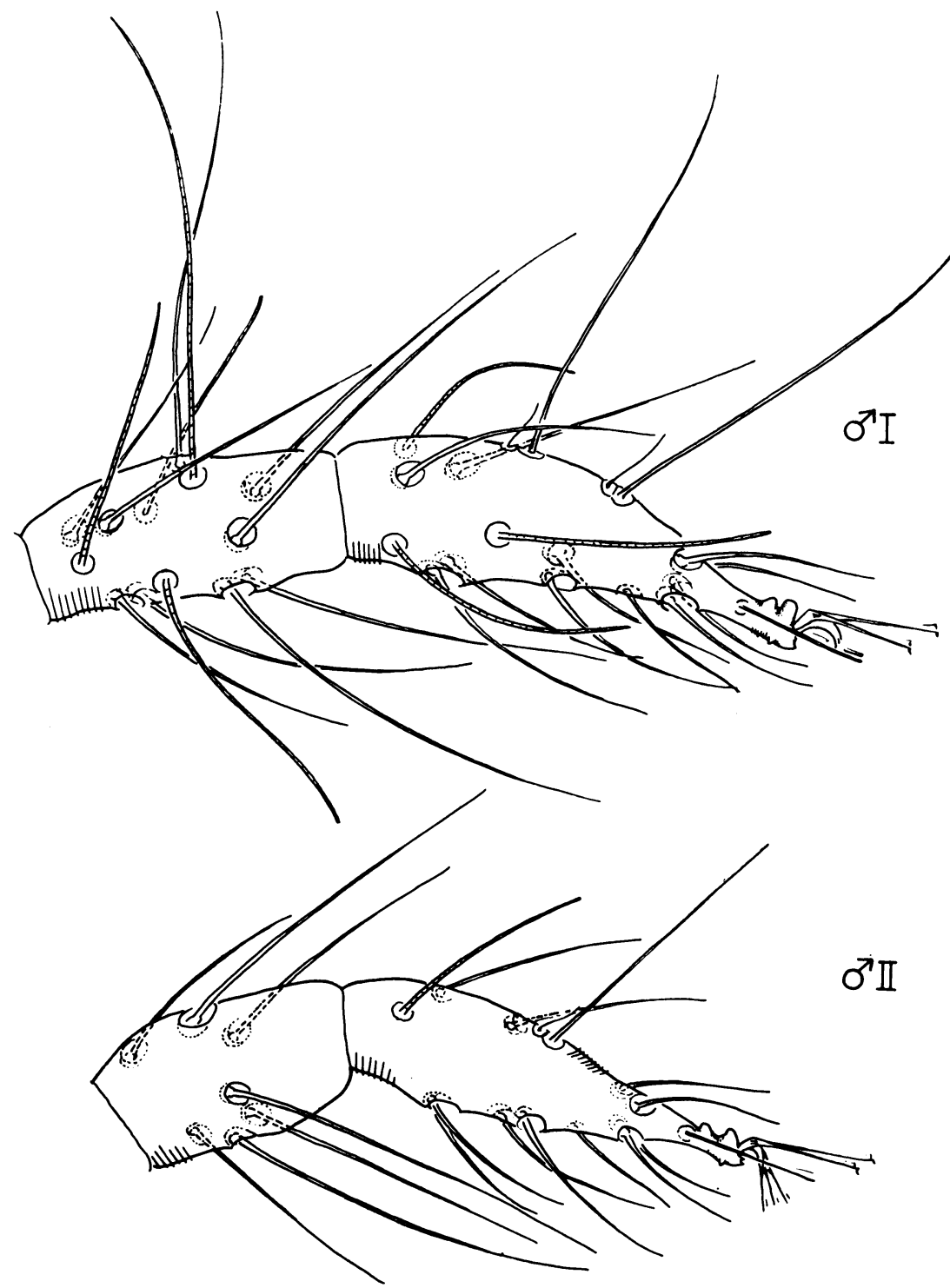

Fig. 92. Tetranychus lombardinii: tibia and tarsus I of male and tibia and tarsus II of male.

four sensory setae, tarsus I with four tactile and two sensory setae proximal to duplexes; empodium I with proximoventral spurs slender and tridigitate, the dorsomedian claw very tiny. Tibia II with seven tactile setae; empodium II with proximoventral hairs and a minute dorsomedian claw. Idiosoma with dorsal setae slender and long, pubescent. Aedeagus with shaft gradually 
narrowing until just before the bend dorsad; knob with axis nearly parallel to that of shaft, the anterior development small but quite distinct, obtusely angulate and larger than the small, acute posterior angulation, the dorsal margin slightly curved. Length of body $370 \mu$.

Female. Palpus with terminal sensillum stout, about twice as long as broad. Tibia I with nine tactile and one sensory setae; tarsus I with four

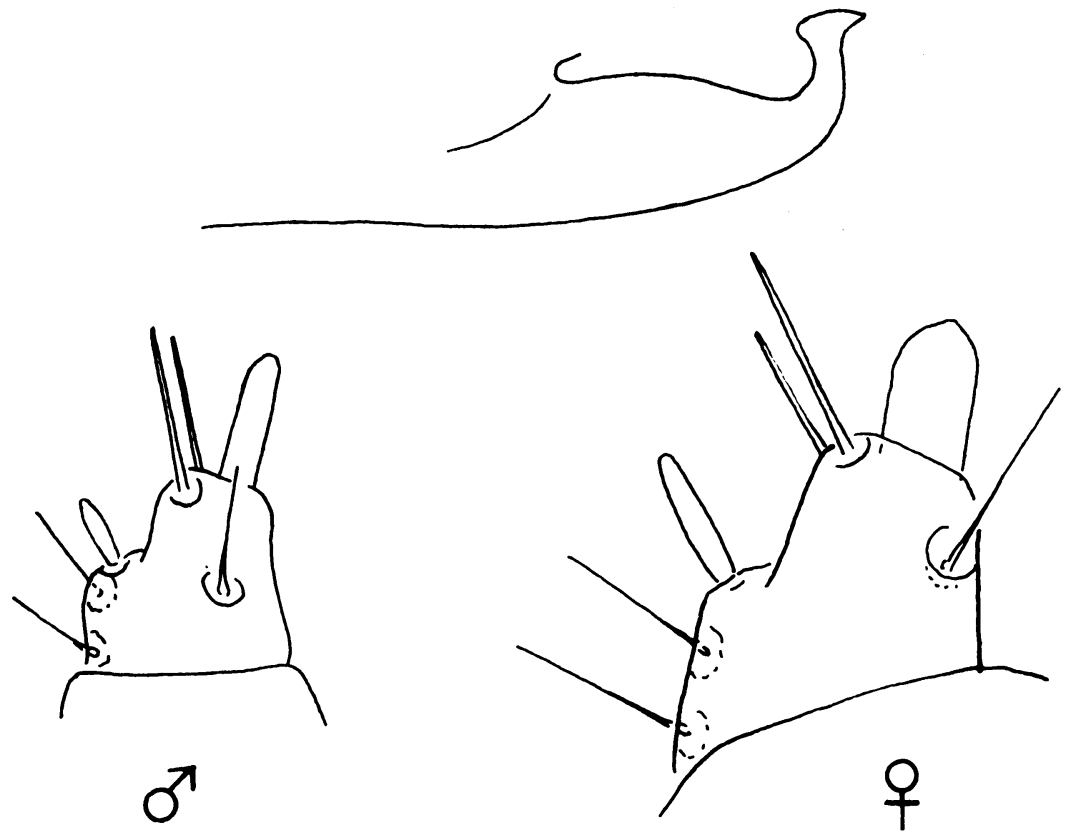

Fig. 93. Tetranychus lombardinii: aedeagus, and terminal segments of male and female palpi.

tactile setae well proximal to duplexes. Empodium without dorsomedian claw. Hysterosoma with longitudinal striae between third pair of dorsocentrals and inner sacrals; dorsal striae with tiny, widely spaced, semicircular to triangular lobes. Podosoma with medioventral striae smooth (or very weakly lobed on posterior part). Length of body $517 \mu$; greatest width of body $319 \mu$.

Holotype. Lorenco, Marques, Portugese East Africa; February, 1957 (M. C. Rodriquez), on cotton; in the British Museum (Natural History).

Paratypes. Three males, 7 females, Marques, Portugese East Africa, February, 1957 (M. C. Rodriquez), on cotton ; 1 male, 5 females, Sabi Valley, Southern Rhodesia, August, 1956, on cotton ; 1 male, Coffee Research Station, Ruiru, Kenya, March 28, on spinach.

This species in named in honor of Dr. G. Lombardini, Statione di Entomologia Agraria, Firenze, Italy. 


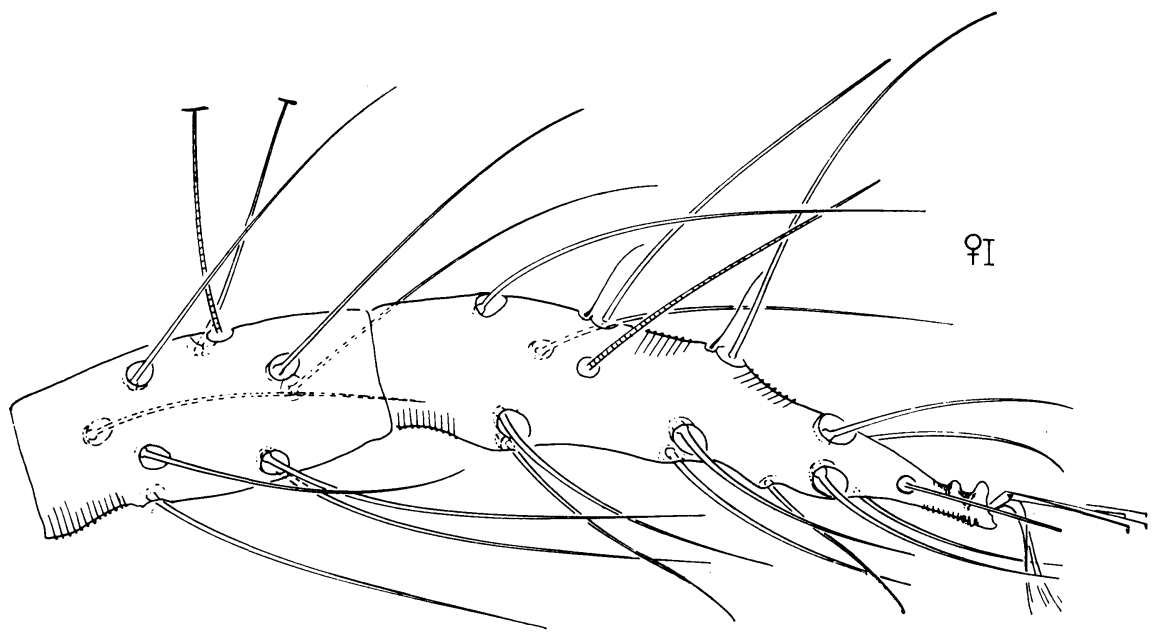

Fig. 94. Tetranychus cinnabarinus: tibia and tarsus I of female.

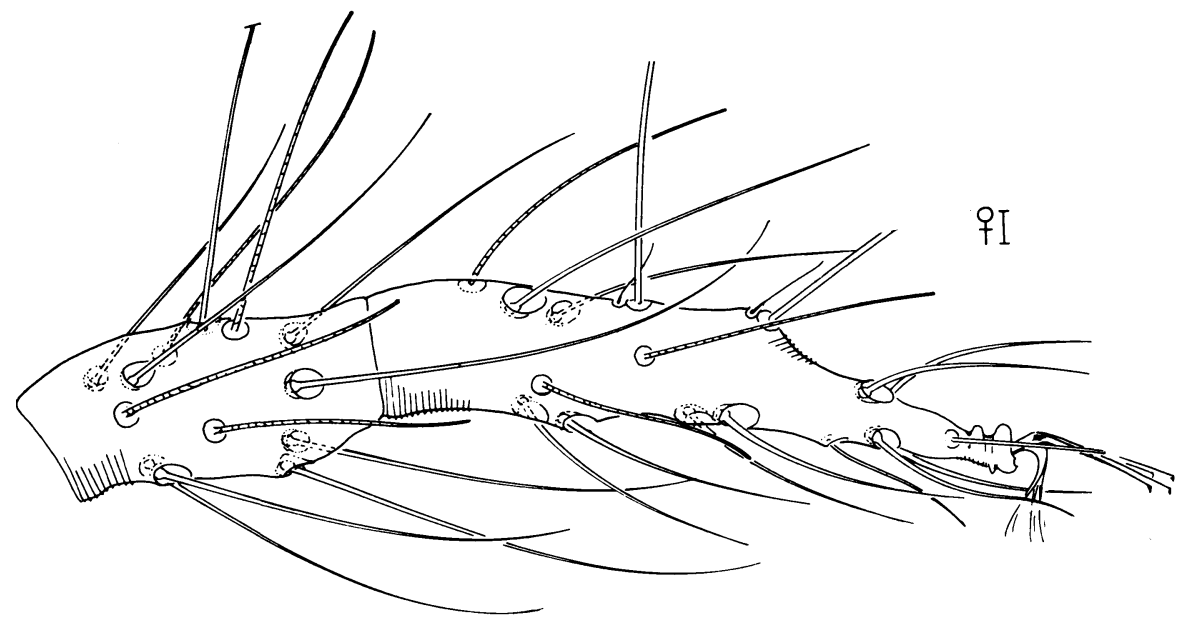

Fig. 95. Tetranychus cinnabarinus: tibia and tarsus I of female, "multisetis" type.

\section{Tetranychus cinnabarinus (Boisduval)}

(Figs. 94 to 97 )

Acarus cinnabarinus Boisduval. 1867, Ent. Hort., p. 88.

Tetranychus cucurbitacearum Sayed, 1946, Bul. Soc. Fouad $1^{\text {er }}$ Ent. 30: 90. 


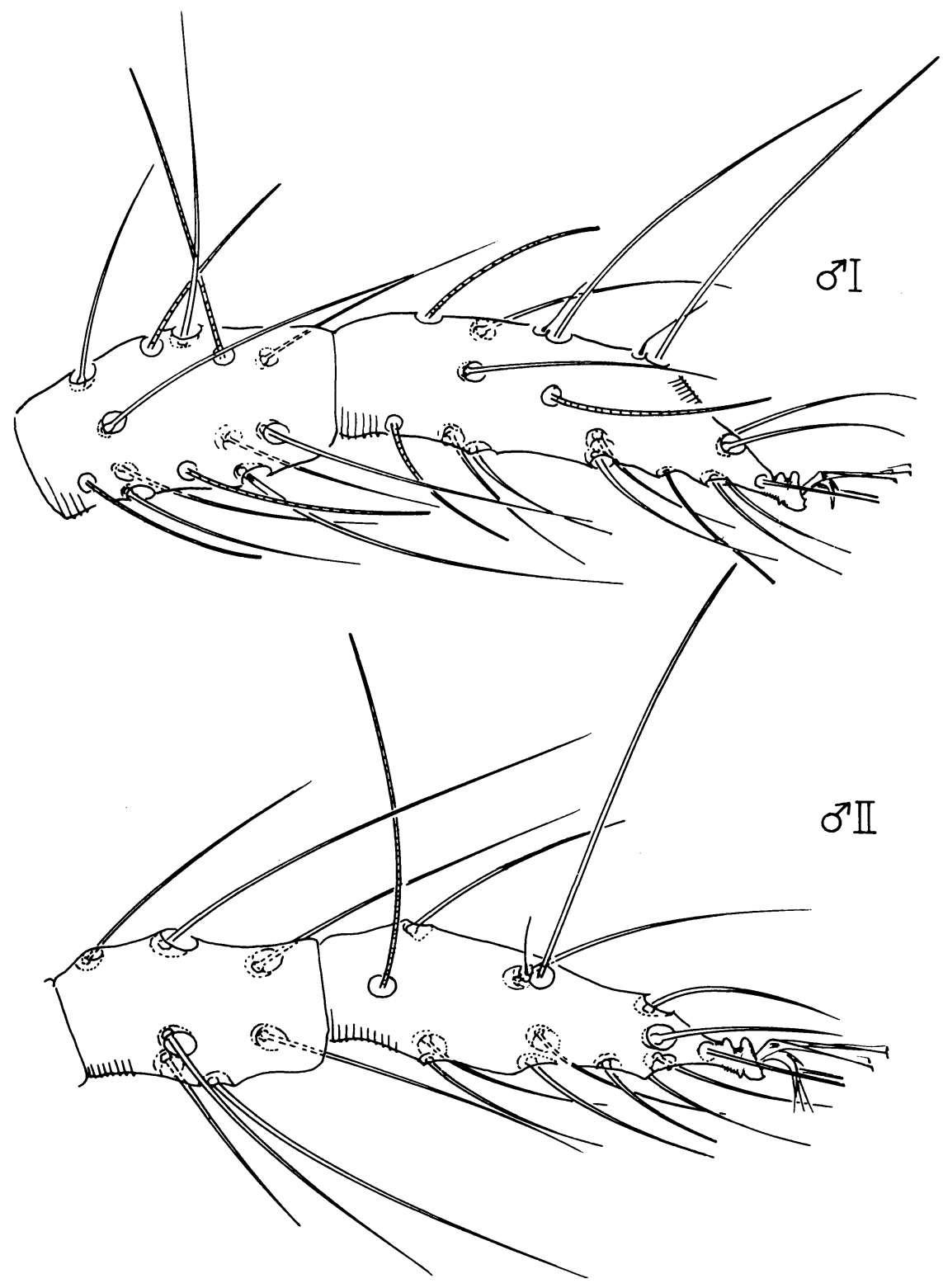

Fig. 96. Tetranychus cinnabarinus: tibia and tarsus I of male and tibia and tarsus II of male. 


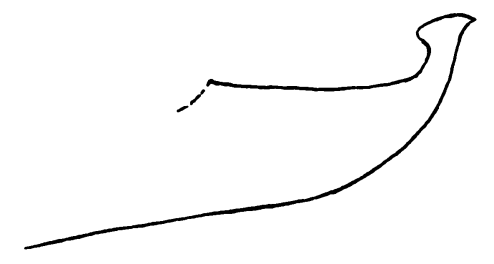

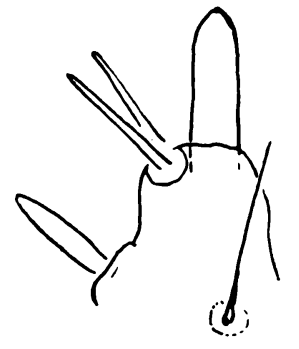

ठ
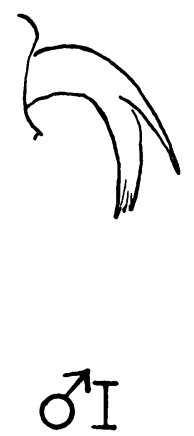

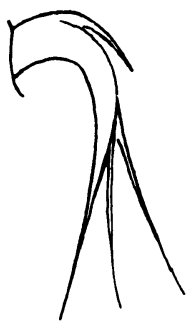

ôI

Fig. 97. Tetranychus cinnabarinus: aedeagus; termination of male palpus; empodium I of male and empodium II of male.
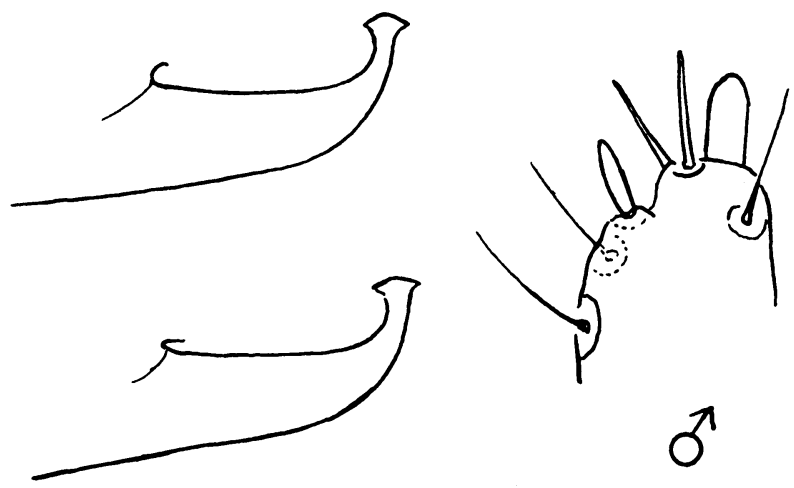

Fig. 98. Tetranychus telarius: aedeagus and termination of palpus of male.

Boudreaux (1956) clarified the status of Tetranychus cinnabarinus, showing that it is a valid species with morphological characters to separate it from $T$. telarius (Linnaeus), with which it has been confused. As now recognized, $T$. cinnabarinus is known to occur in the United States (only in greenhouses in the northern part), Europe (only in greenhouses in the northern part), Africa, the Middle East, Japan, Hawaii, and Argentina. 


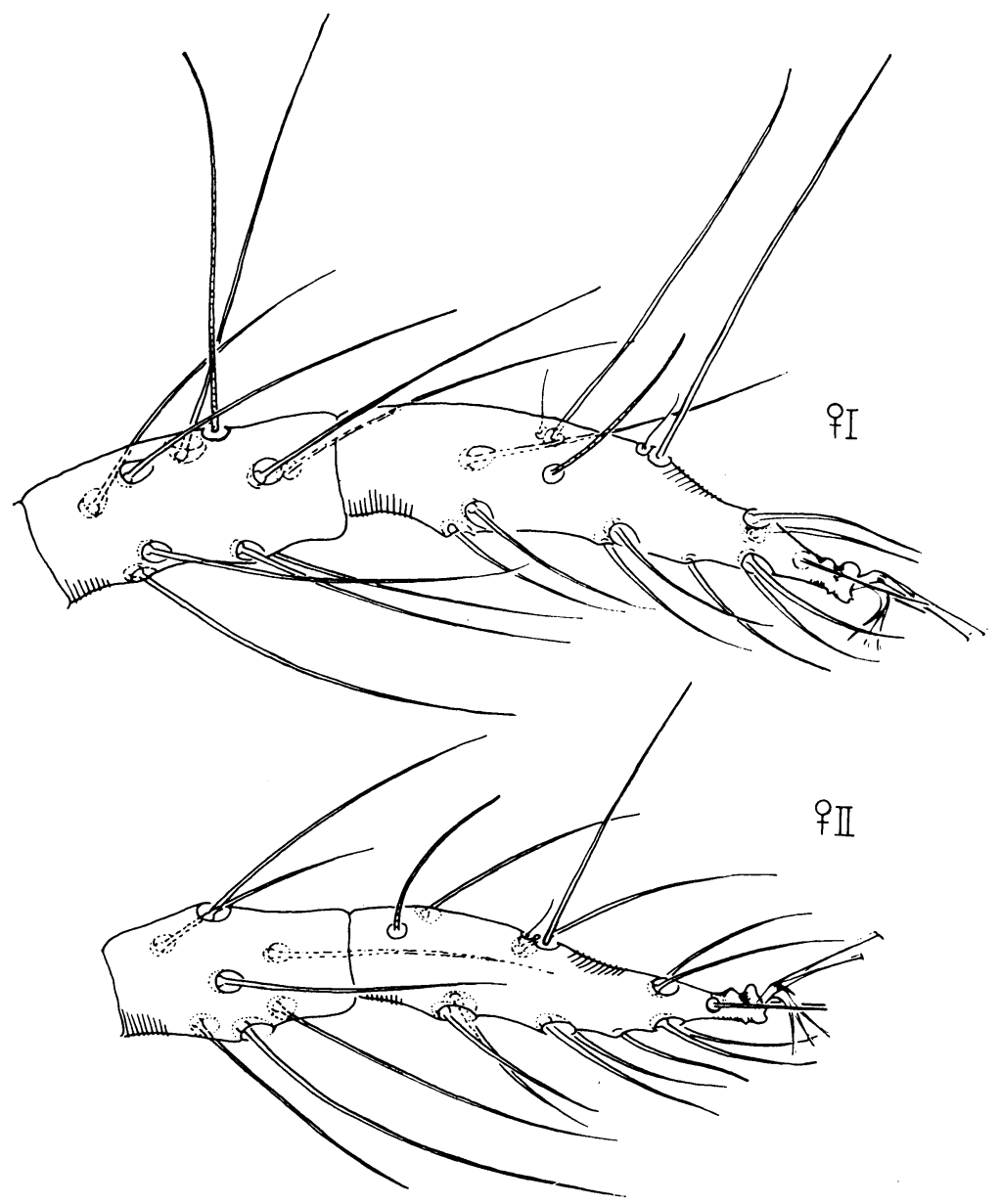

Fig. 99. Tetranychus telarius: tibia and tarsus I of female and tibia and tarsus I of female.

Specimens that we have studied from Africa in which both sexes are associated are from Namulonge, Uganda, on cotton; Machakos, Kenya, on leek; Nairobi, Kenya, on Lathyrus odorata; Lwiro, Belgian Congo, on rose and a leguminaceous tree; and Stellenbosch, Union of South Africa, November 11, 1958 (R. J. Kriegler), on hollyhock.

\section{Tetranychus telarius (Linnaeus)}

(Figs. 98, 99, 100)

Acarus telarius Linnaeus 1758, Syst. Nat. 10: 616.

Pritchard and Baker (1955) reviewed the nomenclatural problems in connection with Tetranychus telarius, and Boudreaux (1956) gave more details with regard to its morphological characters. As now recognized, this 


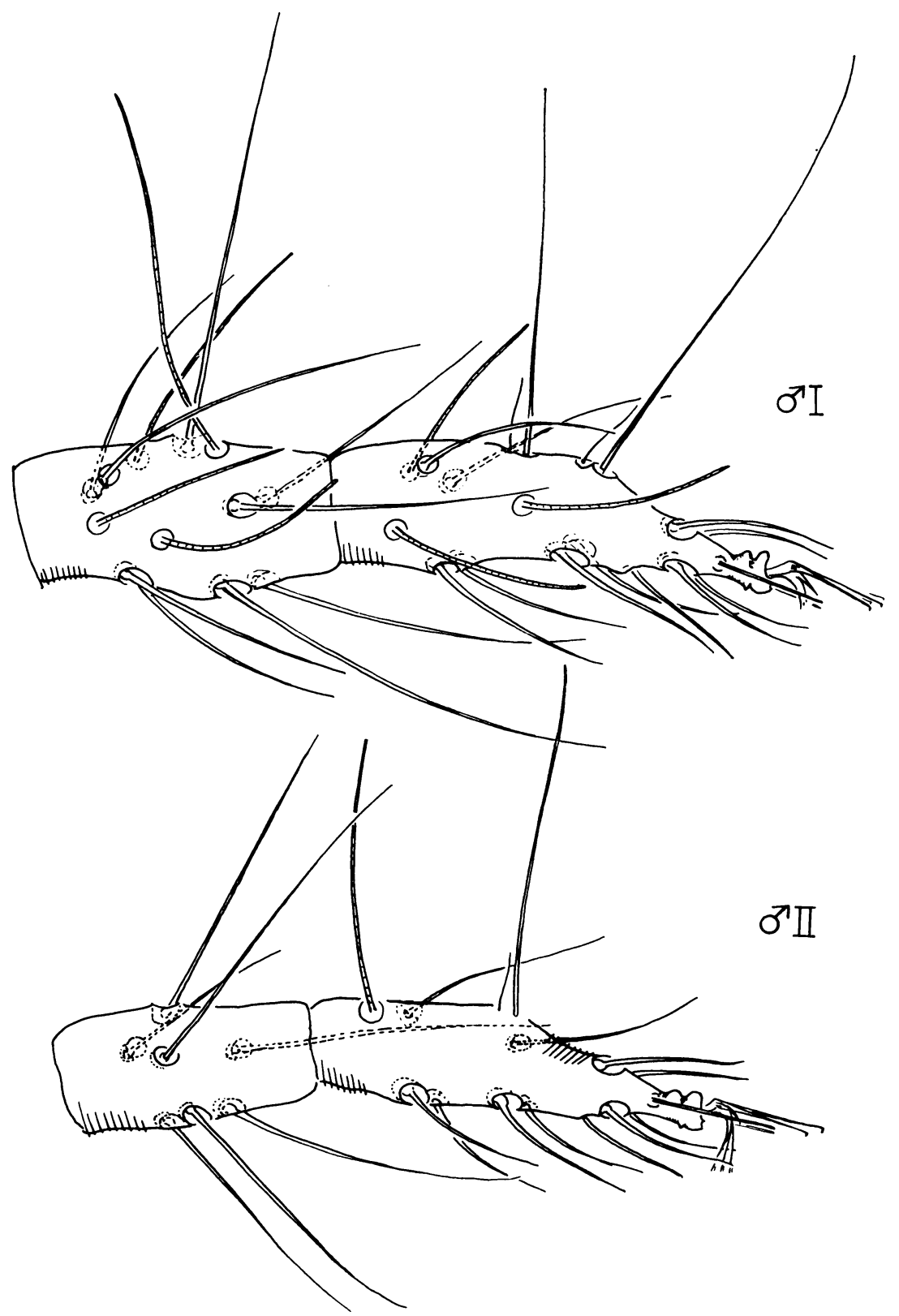

Fig. 100. Tetranychus telarius: tibia and tarsus I of male and tibia and tarsus II of male. 
species is known from Europe, North America, Japan, Australia, New Zealand, the Middle East, and Africa.

North African material, represented by both sexes, that we have studied is from Muri, Sudan, on lubia plant; and Gureir, Sudan, on Dolichos lablab. An additional collection is from Bukavu, Belgian Congo, on carnation. The presence of this species in South Africa (Pritchard and Baker, 1955) is unconfirmed since our females from Transvaal, on apple, represent the nonfeeding phase.

\section{FAMILY TUCKERELLIDAE BAKER AND PRITCHARD, 1953}

Tuckerellidae Baker and Pritchard, 1953, Ann. Ent. Soc. Amer. 46: 251.

The family Tuckerellidae is small, containing only one genus and three known species, of which one, Tuckerella spechtae Womersley (1957), is known only from Australia. The series of filamentous appendages at the caudal end of the body is characteristic of the group, and the female genitalia are distinctive. The male is still unknown.

\section{GENUS TUCKERELLA WOMERSLEY, 1940}

Tuckerella Womersley, 1940, Trans. Roy. Soc. S. Austral. 64: 244.

Members of the genus Tuckerella are found primarily on the twigs of shrubs and trees, although occasional specimens are found on the leaves or fruit. Two species are known from the Ethiopian Region, and they may be distinguished by the following key.

\section{Key to Species}

1. Cauda with five pairs of whiplike setae .............. (1) ornata

- Cauda with six pairs of whiplike setae ........... (2) pavoniformis

\section{Tuckerella ornata (Tucker)}

Tenuipalpus ornatus Tucker, 1926, S. Afr. Dept. Afr. Div. Ent. Mem. 5: 4. Tuckerella ornata (Tucker), Baker and Pritchard, 1953, Ann. Ent. Soc. Amer. 46: 251.

Tuckerella ornata was originally described from South Africa, on the basis of specimens from Western Cape Province and Transvaal, on orange. We have studied specimens from Natal, on citrus. Additional collections are from Florida, Guatemala, and the Philippines, on Bauhenia, Hevea, Mammea, and Phalaenopsis (Baker and Pritchard, 1953a).

\section{Tuckerella pavoniformis (Ewing)}

Eupalopsis pavoniformis Ewing, 1922, Proc. Ent. Soc. Wash. 24: 106. Tuckerella pavoniformis (Ewing), Moutia, 1958, Bul. Ent. Res. 49: 62.

Tuckerella pavoniformis is a widespread species in the tropics, being known from Australia, Hawaii, southern California, and Mauritius, on such hosts as hibiscus, papaya, and citrus. We have studied specimens recorded by Moutia, from Mauritius, on cotoneaster. 


\title{
FAMILY TENUIPALPIDAE BERLESE, 1913
}

\author{
Tenuipalpidae Berlese, 1913, Acaroth. Ital., p. 17
}

Tenuipalpid mites are the only tetranychoids that do not have a "claw" on the fourth palpal segment, and the number of palpal segments is strongly reduced in some genera. The mites are small and flat, usually reddish in color, and their eggs are elliptical and reddish. Most species feed on the under surface of the leaves of plants, usually perennials, but a few feed on the twigs. They do not produce silken strands.

\section{Key to Genera}

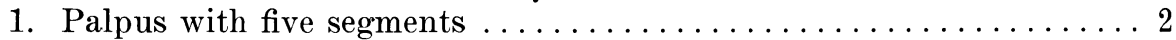

- Palpus with less than five segments $\ldots \ldots \ldots \ldots \ldots \ldots \ldots \ldots \ldots$

2. Female with four pairs of legs ...............egyptobia (below)

- Female with three pairs of legs ............ Phytoptipalpus (below)

3. Palpus with four segments $\ldots \ldots \ldots \ldots \ldots \ldots \ldots \ldots \ldots \ldots \ldots$

- Palpus with less than four segments ................. 5

4. Hysterosoma with first dorsosublateral setae present.Cenopalpus (p. 561)

- Hysterosoma without dorsosublateral setae........ Brevipalpus (p. 562)

5. Podosoma very broad and opisthosoma narrow.... Tenuipalpus (p. 564)

- Podosoma not strongly differentiated from opisthosoma .........6

6. Palpus with three segments ; idiosoma slender

Dolichotetranychus (p. 570)

- Palpus with two segments; idiosoma orbicular .............. 7

7. Idiosoma with dorsal setae slender............... Raoiella (p. 570)

- Idiosoma with dorsal setae broad and veined.Phyllotetranychus (p. 571)

\section{GENUS AEGYPTOBIA SAYED}

Aegyptobia Sayed, 1950, Proc. Eighth Internatl. Congr. Ent., p. 1015.

The genus Aegyptobia may be recognized by its having five palpal segments and four pairs of dorsosublateral hysterosomals. One species is known from Africa.

\section{Aegyptobia trägårdhi Sayed}

Aegyptobia trägårdhi Sayed, 1950, Proc. Eighth Internatl. Congr. Ent., p. 1018 ; Pritchard and Baker, 1958, Univ. Calif. Publ. Ent. 14(3) : 181.

Pentamerismus trägårdhi (Sayed), Baker and Pritchard, 1954, Wasmann Jour. Biol. 11(3): 355 .

This species is known from Dokki and Giza, Egypt, on Thuja orientalis.

\section{GENUS PHYTOPTIPALPUS TRÄGÅRDH, 1904}

Phytoptipalpus Trägårdh, 1904, Results Swed. Zool. Exped. Egypt White Nile 20: 9 .

The genus Phytoptipalpus may be recognized by its having five palpal segments and the female's having only three pairs of legs. The body is ovate and finely striate. In the single African species the male also bears only three pairs of legs. The male of $P$. albizziae Pritchard and Baker, 1958, from India, has four pairs of legs. The mites form cortical stem galls. 


\section{Phytoptipalpus paradoxus Trägårdh}

Phytoptipalpus paradoxus Trägårdh, 1904, Results Swed. Zool. Exped. Egypt White Nile 20:10; Sayed, 1942, Bul. Soc. Fouad 1 ${ }^{\text {er }}$ Ent. 26: 116; Pritchard and Baker, 1958, Univ. Calif. Publ. Ent. 14(3): 189.

This species was described from Kaka, Sudan, and Sayed (1942c) stated that it is found all over Egypt. It forms cortical galls on Acacia nilotica.

\section{GENUS CENOPALPUS PRITCHARD AND BAKER, 1958}

Cenopalpus Pritchard and Baker, 1958, Univ. Calif. Publ. Ent. 14(3) : 190.

Cenopalpus is characterized by having four palpal segments and one pair of dorsosublateral hysterosomals. The body is elliptical and sculptured. The genus is found only in Europe and Africa.

\section{Key to Species}

1. Idiosoma with dorsal setae acuminate distally ............... 2

- Idiosoma with dorsal setae clavate ................. (1) natalensis

2. Propodosoma with dorsal setae elliptic lanceolate....(2) lanceolatisetae

- Propodosoma with dorsal setae setiform ................ (3) pulcher

\section{Cenopalpus natalensis (Lawrence)}

Tenuipalpus natalensis Lawrence, 1943, Trans. Roy. Soc. S. Afr. 30: 45.

Brevipalpus natalensis (Lawrence), Baker, 1949, Amer. Midl. Nat. 42: 384;

Baker and Pritchard, 1952, Ann. Mag. Nat. Hist. (ser. 12) 5: 609.

Cenopalpus natalensis (Lawrence), Pritchard and Baker, 1958, Univ. Calif. Publ. Ent. 14(3): 192.

Cenopalpus natalensis is known only from Karklooj, near Pietermaritzburg, South Africa. It occurs on Halleria lucida.

\section{Cenopalpus lanceolatisetae (Attiah)}

Brevipalpus lanceolatisetae Attiah, 1956, Bul. Soc. Ent. Egypte 40: 436. Cenopalpus lanceolatisetae (Attiah), Pritchard and Baker, 1958, Univ. Calif.

Publ. Ent. 14(3) : 192.

This species is known only from Upper and Lower Egypt, on prune, apricot, pear, and apple.

\section{Cenopalpus pulcher (Canestrini and Fanzago)}

Caligonus pulcher Canestrini and Fanzago, 1876, Atti Acc. Sci. Ven.-Trent.Ist. 5: 134 .

Cenopalpus pulcher (Canestrini and Fanzago), Pritchard and Baker, 1958, Univ. Calif. Publ. Ent. 14(3) : 194.

Tenuipalpus oudemansi Geijskes, Sayed, 1942, Bul. Soc. Fouad $1^{\text {er }}$ Ent. 26: 99 .

Brevipalpus pyri Sayed, 1946, Bul. Soc. Fouad $1^{\text {er }}$ Ent. 30: 102; Baker, 1949, Amer. Midl. Nat. 42: 371.

Brevipalpus geisenheyneri (Rübsaamen), Baker and Pritchard, 1952, Ann. Mag. Nat. Hist. (ser. 12) 5: 609 ; Attiah, 1956, Bul. Soc. Ent. Egypte 40: 438. Misidentification. 
This species is known from Europe, North Africa, and the Middle East, occurring on apple, willow, plum, apricot, pear, and loquat. African records include Egypt and Algeria.

\section{GENUS BREVIPALPUS DONNADIEU, 1875}

Brevipalpus Donnadieu, 1875, Rech. Serv. Hist. Tetranych., p. 116.

The genus Brevipalpus may be recognized by the four palpal segments and the absence of dorsosublateral hysterosomal setae. The body is ovate and sculptured.

Brevipalpus is a large genus in the Western Hemisphere, where fifty-one species are known, and many of them are host-specific. It is interesting to note that only three species are known from the Ethiopian Region; they all feed on many hosts and are widespread throughout the tropies. Two other species are known from North Africa.

\section{Key to Species}

1. Gnathosoma reaching distal end of genu I. ............... 2

- Gnathosoma not reaching past femur I................... 3

2. Idiosoma with dorsal setae tapering .................. (1) oleae

- Idiosoma with dorsal setae subclavate ................. (2) olearius

3. Hysterosoma with five pairs of dorsolateral setae............. 4

- Hysterosoma with six pairs of dorsolateral setae....... (3) californicus

4. Female with one sensory rod on tarsus II.............. (4) obovatus

— Female with two sensory rods on tarsus II.............. (5) phoenicis

\section{Brevipalpus oleae Baker}

Brevipalpus oleae Baker, 1949, Amer. Midl. Nat. 44: 361; Pritehard and Baker, 1958, Univ. Calif. Publ. Ent. 14(3) : 202.

This species is known only from Morocco, on olive.

\section{Brevipalpus olearius Sayed}

Brevipalpus olearius Sayed, 1950, Proc. Eighth Internatl. Congr. Ent., p. 1018; Attiah, 1956, Bul. Soc. Ent. Egypte 40: 444 ; Pritchard and Baker, 1958, Univ. Calif. Publ. Ent., 14(3) : 202.

Brevipalpus olearius is known only from Egypt, on olive.

\section{Brevipalpus californicus (Banks)}

Tenuipalpus californicus Banks, 1904, Jour. N. Y. Ent. Soc. 12: 55.

Brevipalpus californicus (Banks), Pritchard and Baker, 1958, Univ. Calif. Publ. Ent. 14(3): 216.

Tenuipalpus australis Tucker, 1926, Union S. Afr. Dept. Agric. Ent. Mem. 5: 3; Lawrence, 1943, Trans. Roy. Soc. S. Afr. 30: 39.

Brevipalpus australis (Tucker), Baker, 1949, Amer. Midl. Nat. 42: 379; Pritchard and Baker, 1952, Univ. Calif. Publ. Ent. 9(1) : 29 ; Attiah, 1956, Bul. Soc. Ent. Egypte 40: 443. 
Brevipalpus californicus is widespread in the tropics and is known to occur outdoors in the very southern United States (California, Texas, and Florida), Mexico, Hawaii, Ceylon, Malaya, Australia, the Middle East, and Africa. North African records are from Tripolitania, Algeria, and Egypt. Tucker (1926) recorded this species from Cape Province, Natal, Transvaal, and Rhodesia in southern Africa. B. californicus feeds on a wide variety of hosts, but it is of most importance on eitrus and orchids.

We have studied specimens from southern Africa as follows: Nelspruit, Transvaal, August, 1950 (Stofberg), on citrus; Letaba, Transvaal, July, 1950, on citrus; Muden, Natal, June 9, 1950, on citrus ; Leopoldville, Belgian Congo, April 10, 1955 (E. W. Baker), on ornamentals; Stanleyville, Belgian Congo, April 18, 1955 (E. W. Baker), on croton; Gangala na Bodio, Belgian Congo, April 30, 1955 (E. W. Baker) on ?Jatropha curcas; Astrida, RuandaUrundi, May 22, 1955 (E. W. Baker), on elderberry. Specimens were also examined from Barkly, Mauritius, February, 1955 (L. A. Moutia), on Cotoneaster.

\section{Brevipalpus obovatus Donnadieu}

Brevipalpus obovatus Donnadieu, 1875, Rech. Serv. Hist. Tetranych., p. 116 ; Pritchard and Baker, 1958, Univ. Calif. Publ. Ent. 14(3) : 231.

Brevipalpus inornatus (Banks), Attiah, 1956, Bul. Soc. Ent. Egypte 40: 440.

Brevipalpus obovatus is a widespread species, being known to occur in the United States, Venezuela and Argentina, Hawaii, Japan, Ceylon, New Zealand, Australia, the Middle East, Europe, and Africa. A wide range of plants serves as hosts.

Pritchard and Baker (1958) recorded specimens received from Kenya. Attiah (1956) recorded collections from Egypt under the name B. inornatus (Banks). Other African specimens studied by us are as follows: Kysenyi, Belgian Congo, May 11, 1955 (E. W. Baker), on Cestrum sp.; Lwiro, Belgian Congo, May 16, 1955 (E. W. Baker), on Bignonia sp.; Stellenbosch, South Africa, April 27, 1959 (P. J. Kriegler), on canary creeper ; and Beau Songe, Mauritius, October 10, 1954 (L. A. Moutia), on Verbena bonariensis.

\section{Brevipalpus phoenicis (Geijskes)}

Tenuipalpus phoenicis Geijskes, 1939, Meded. Landbouwh. Wageningen $42(4): 230$.

Brevipalpus phoenicis (Geijskes), Sayed, 1946, Bul. Soc. Fouad $1^{\text {er }}$ Ent. 30: 99 ; Attiah, 1956, Bul. Soc. Egypte 40: 442; Pritchard and Baker, 1958, Univ. Calif. Publ. Ent. 14(3): 233; Moutia, 1958, Bul. Ent. Res. 49: 61. Brevipalpus phoenicis is widespread in the tropics. It is known from India, Ceylon, Malaya, Taiwan, Hawaii, Argentina, Trinidad, Cuba, Florida (and greenhouses in other parts of the United States), greenhouses in Europe, Africa, and Mauritius. Sayed (1946b) and Attiah (1956) reported this species in Egypt; Moutia (1958) reported its importance in Mauritius; and Pritchard and Baker (1958) recorded it from Kenya and Tanganyika. A wide variety of plants serves as hosts, of which the most economically important are citrus and tea. 
Other African specimens studied by us are as follows: Leopoldville, Belgian Congo, April 8-15, 1955 (E. W. Baker), on palm, fern, Combretum sp., lemon, orange, papaya, frangipani, and hibiscus ; INEAC, Mulunga, Belgian Congo, May 18, 1955 (E. W. Baker), on citrus, grape, Cinchona, peach, hickory, and Acrocarpus fraxinifolius; Stanleyville, Belgian Congo, April 18, 1955 (E. W. Baker), on Bridelia sp.; Beni, Belgian Congo, May 7, 1955 (E. W. Baker), on Tithonia speciosa; Mt. Hoyo, Belgian Congo, May 4, 1955 (E. W. Baker), on peach, hibiscus, and Datura sp. ; Nioka, Belgian Congo, May 2, 1955 (E. W. Baker), on frangipani ; Kysenyi, Belgian Congo, May 17, 1955 (E. W. Baker), on phlox; and Astrida, Ruanda-Urundi, Belgian Congo, May 22, 1955 (E. W. Baker), on ivy and citrus.

\section{GENUS TENUIPALPUS DONNADIEU 1875}

Tenuipalpus Donnadieu, 1875, Rech. Serv. Hist. Tetranych., p. 111.

The genus Tenuipalpus is distinctive in that the rostral shield covers the gnathosoma, and the one- to three-segmented palpus bears a conspicuous pectinate seta. The stylophore lacks longitudinal ribs, and the body is strongly flattened with the podosoma broad, the opisthosoma narrower, and the dorsal integument variously sculptured or punctate. The mites are often semitransparent and they are found on glabrous leaves, usually on the under surfaces. Hosts are usually specific.

\section{Key to Species}

1. Hysterosoma with penultimate pair of dorsal setae filamentous......2

- Hysterosoma with filamentous setae absent..........(6) quadrisetosus

2. Hysterosoma with three pairs of dorsocentral setae. . . . . . . . . . 3

- Hysterosoma with one pair of dorsocentral setae.......... (5) granati

3. Idiososoma with a strongly rugose mediodorsal ridge; hysterosoma with dorsocentral setae lanceolate ............... (1) attiahi

- Idiosoma with dorsum flat and nearly smooth; hysterosoma with dorsocentral setae small and setiform ............... 4

4. Hysterosoma with a differentiated expansion anterior to coxa III ... 5

- Hysterosoma undifferentiated anterior to coxa III. . . . . . . (2) lawrencei

5. Hysterosoma with a broad, trapezoidal expansion anterior to

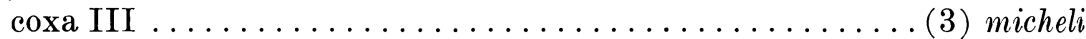

- Hysterosoma with a slender projection anterior to coxa III

(4) podocarpi

\section{Tenuipalpus attiahi, new species}

(Fig. 101)

The female of Tenuipalpus attiahi may be recognized by having a single anterior and a single posterior pair of medioventral podosomal setae, the dorsocentral hysterosomals lanceolate, and irregularly transverse rugosities on the dorsomedian crest of the idiosoma. This species is allied to T. tetrazygiae De Leon (Florida), to which it will run in the key by Pritchard and Baker (1958). The male and nymphs are unknown. 


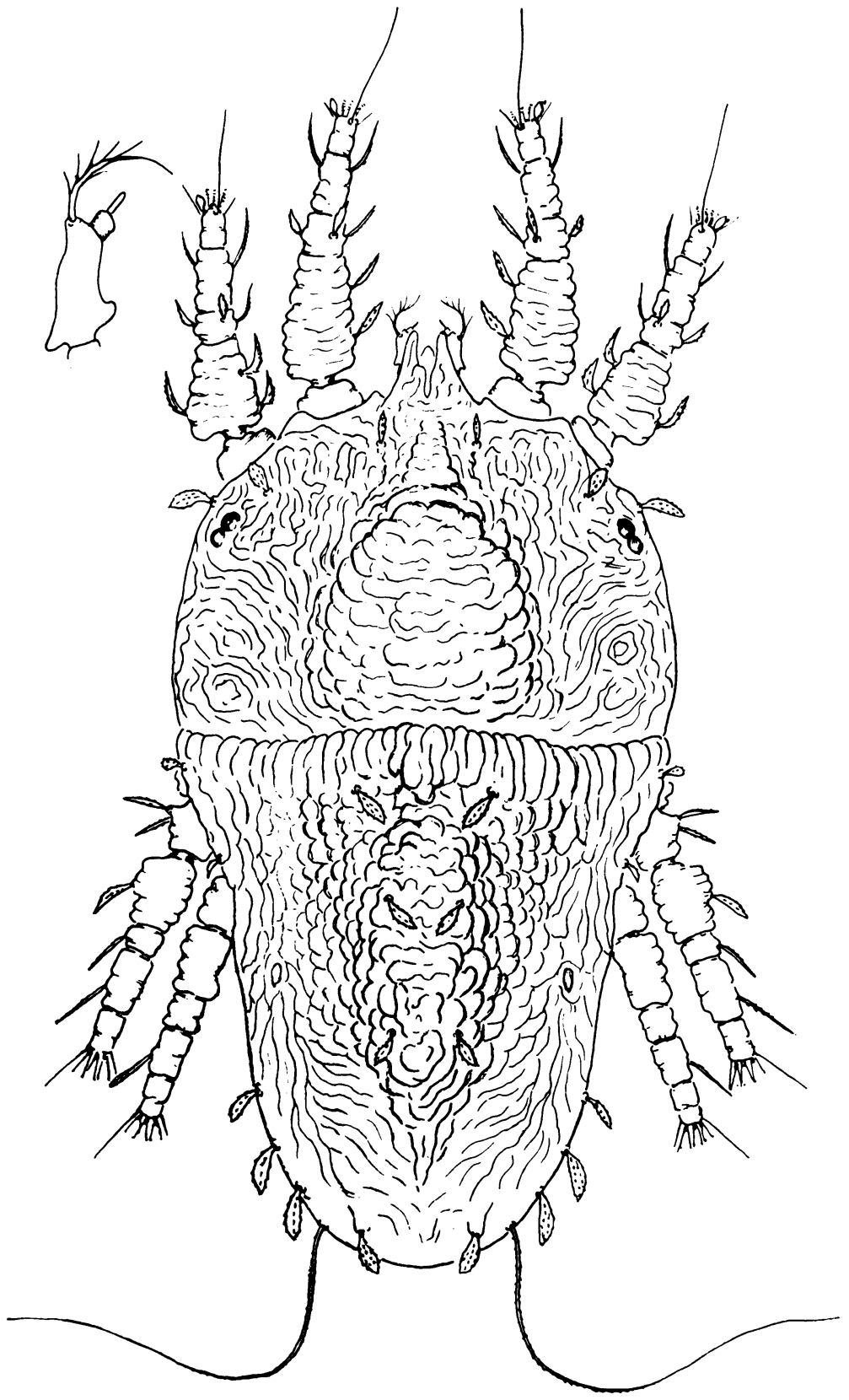

Fig. 101. Tenuipalpus attiahi: dorsal aspect of female, with enlargement of palpus. 
Female. Gnathosoma with a pair of ventral setae. Palpus with three segments, the first very small, the second with a proximal angulation exteriorly, a proximal enlargement interiorly, and bearing a dorsodistal seta with dorsal pectinations, the third with a terminal sensory rod. Femur I with two lanceolate, serrate setae on inner side and two setiform ventral setae, the inner ventral one bearing sparse pectinations; genu I with three lanceolate, serrate setae; tibia I with a long, serrate seta on inner side, a shorter, serrate seta on outer side, and three setiform setae ventrally; tarsus I with a single sensory rod. Femur II with outer seta lanceolate, serrate; tarsus II with a single sensory rod. Coxa III with two lanceolate, serrate setae; femur III with an outer seta and a ventral seta, both lanceolate, serrate; genu III with an outer seta. Propodosoma but slightly developed anterior to eyes; hysterosoma not developed anterior to coxa III ; idiosoma with dorsomedian ridge well developed and bearing irregularly transverse elevations, the sides flattened and irregularly rugose. Dorsal setae of body mostly moderately lanceolate, serrate, the first dorsal propodosomal and first dorsolateral hysterosomal smaller, the second dorsal propodosomal and humeral smaller and spatulate; three pairs of dorsocentral hysterosomals and four pairs of caudal opisthosomals plus a pair of penultimate flagelliform setae. Podosoma with a short pair of anterior medioventral setae and a long pair of posterior medioventrals; ventral plate separate and bearing a pair of nude setae on caudal margin; genital plate with two pairs of nude setae on caudal margin. Length of body $363 \mu$; greatest width of body $191 \mu$.

Holotype. Female, Lubero, Belgian Congo, May 9, 1955 (E. W. Baker), on Podocarpus usambarensis; type no. 2503 in the U. S. National Museum.

Paratypes. Eleven females, Lubero, Belgian Congo, May 9, 1955 (E. W. Baker), on Podocarpus usambarensis.

Three females were also collected on the same host at INEAC, Mulunga, Belgian Congo, May 18, 1955 (E. W. Baker).

This species is named in honor of Mr. Hassan H. Attiah, Ministry of Agriculture, Dokki, Egypt.

\section{Tenuipalpus lawrencei, new species}

(Figs. 102, 103)

The female of Tenuipalpus lawrencei may be recognized by having the podosoma with a single pair of anterior and a single pair of posterior medioventral setae, the three pairs of dorsocentral hysterosomals minute, the propodosoma smooth mediodorsally, and the third dorsal propodosomal elongate-spatulate. It will trace to couplet 16 in the key by Pritchard and Baker (1958) containing T. japonicus Ehara (Japan), which has irregularly longitudinal striae mediodorsally on the propodosoma; and $T$. celtidis Pritchard and Baker (Florida), which has the third dorsal propodosomal acutely tapering.

Female. Gnathosoma with a pair of ventral setae. Palpus three-segmented, the first segment very small, the second segment long and slender and bearing a pectinate seta, the third segment with a long and a very short seta terminally. Femur I with inner dorsal seta lanceolate and serrate, the inner distal seta similar but smaller; genu I with an inner dorsal seta; tibia I with 


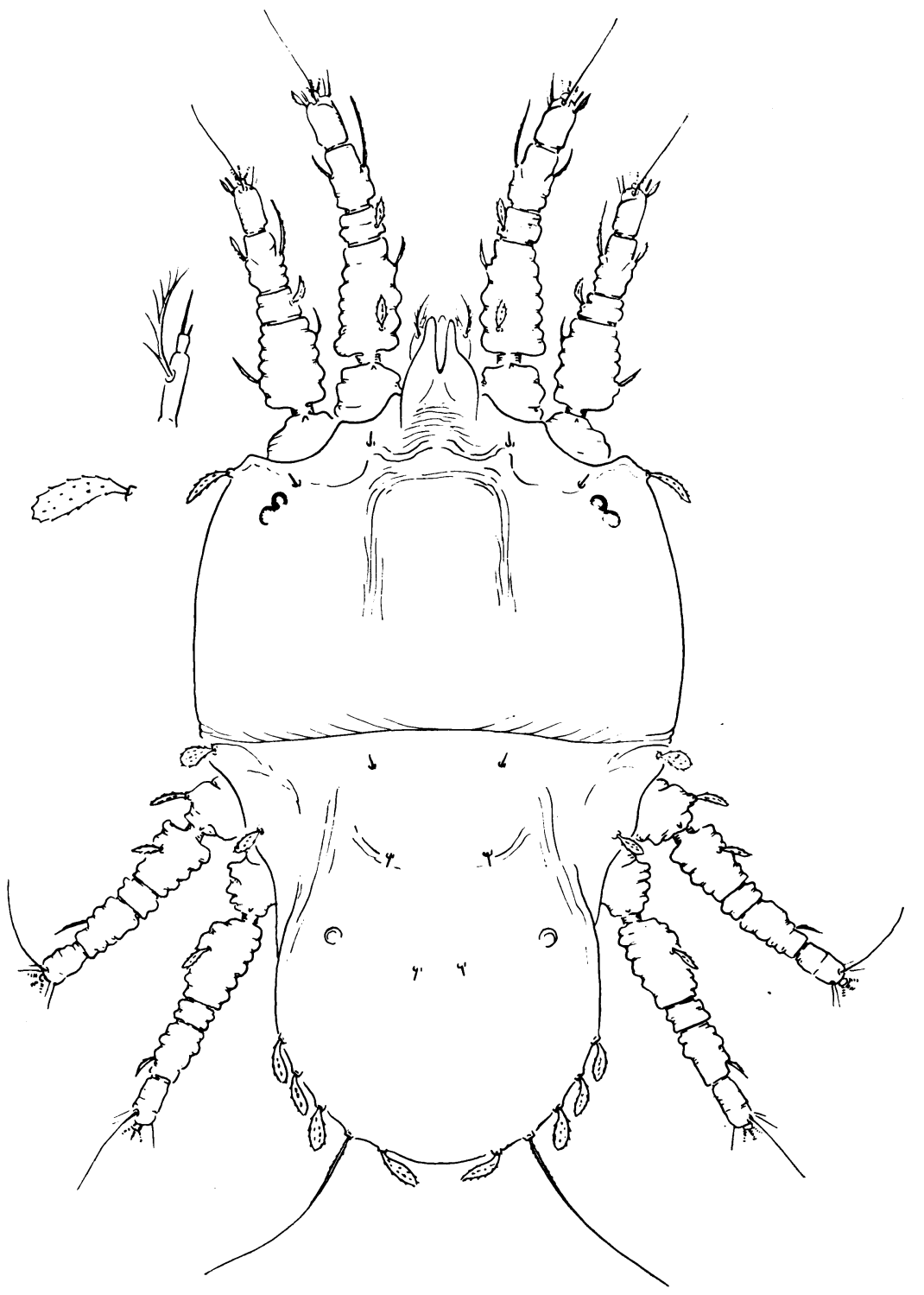

Fig. 102. Tenuipalpus lawrencei: dorsal aspect of female, with enlargement of palpus and third dorsal propodosomal. 


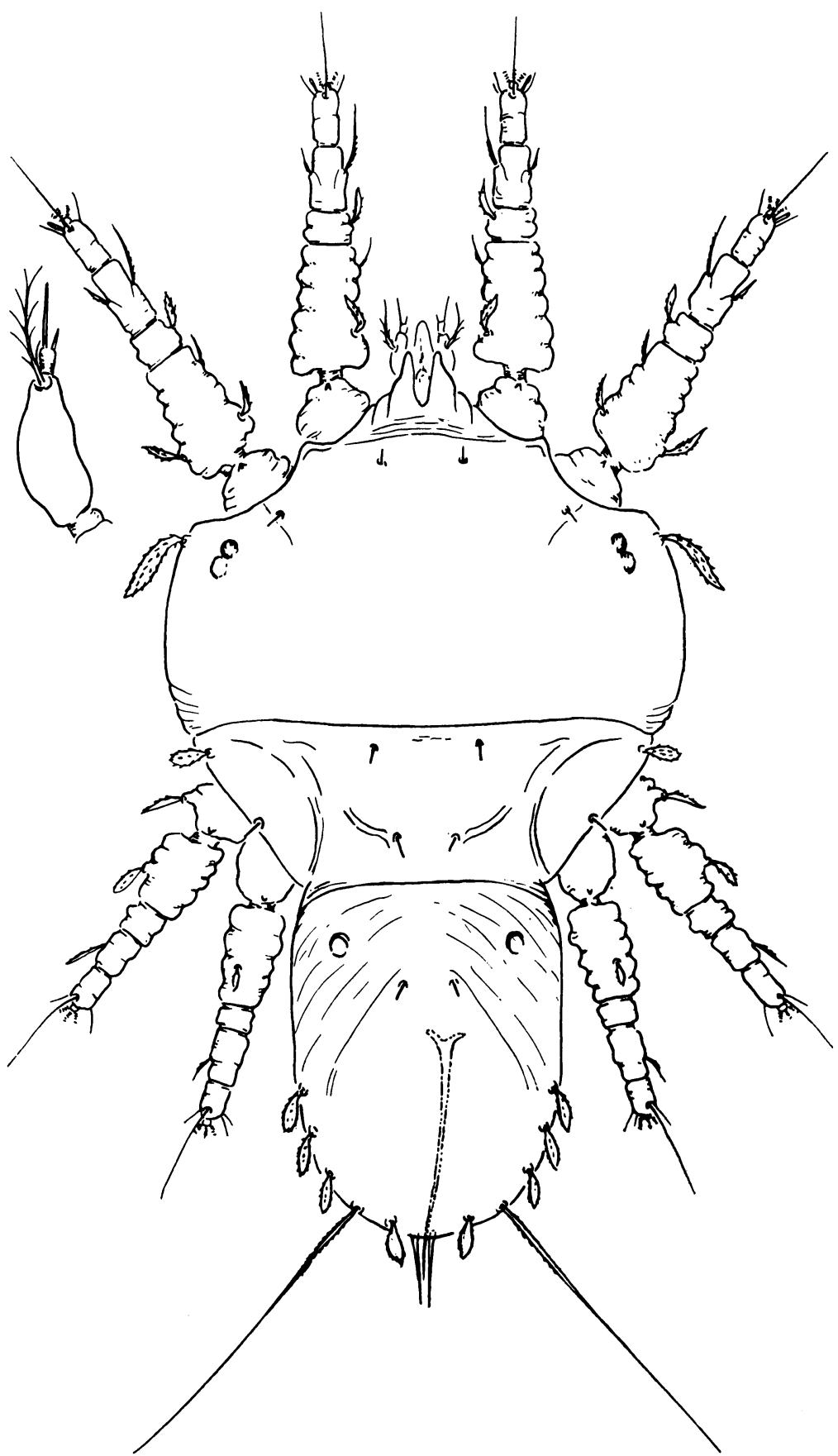

Fig. 103. Tenuipalpus lawrencei: dorsal aspect of male, with enlargement of palpus. 
a long outer and a shorter inner serrate seta and two ventral nude setae; tarsus I with a single sensory rod. Femur II with outer seta lanceolate, serrate; tarsus II with a single sensory rod. Coxa III with a single lanceolate, serrate seta; femur III with an outer and a ventral seta; genu III without setae. Podosoma strongly angulate anterior to eyes; hysterosoma undeveloped anterior to coxa III ; idiosoma smooth except for a striate depression mediolaterally on propodosoma, a striate depression extending anteromedially from coxae IV ; and a longitudinal internal fold extending from each second dorsocentral hysterosomal anterolaterad. First and second dorsal propodosomals and the three pairs of dorsocentral hysterosomals minute; penultimate dorsolateral hysterosomals flagelliform, the other dorsal setae of idiosoma elliptic-lanceolate, serrate; four pairs of broadened setae caudally. Podosoma with a short pair of anterior and a long pair of posterior medioventrals; opisthosoma with all ventral setae short and nude. Length of body $268 \mu$; greatest width of body $153 \mu$.

Male. Similar to female.

Holotype. Female, Leopoldville, Belgian Congo, April 11, 1955 (E. W. Baker), on large tree; type no. 2504 in the U. S. National Museum.

Paratypes. Seven males, 63 females, Leopoldville, Belgian Congo, April 11, 1955 (E. W. Baker), on large tree.

This species is named on honor of Dr. R. F. Lawrence, Natal Museum.

\section{Tenuipalpus micheli Lawrence}

Tenuipalpus micheli Lawrence, 1940, Jour. Ent. Soc. S. Afr. 3: 111; Lawrence, 1943, Trans. Roy. Soc. S. Afr. 30:35; Baker and Pritchard, 1953, Ann. Ent. Soc. Amer. 46: 322 ; Pritchard and Baker, 1958, Univ. Calif. Publ. Ent. 14(3): 239.

This species is known from Umhloti Beach and Stella Wood, Durban, Natal, South Africa, on Chaetacme aristida.

\section{Tenuipalpus podocarpi Lawrence}

Tenuipalpus podocarpi Lawrence, 1943, Trans. Roy. Soc. S. Afr. 30: 40; Baker and Pritchard, 1953, Ann. Ent. Soc. Amer. 46: 324; Pritchard and Baker, 1958, Univ. Calif. Publ. Ent. 14(3): 240.

This species is known only from Cathkin Peak, Drakensberg Mts., Natal, South Africa, on Podocarpus falcata.

\section{Tenuipalpus granati Sayed}

Tenuipalpus orchidarum (Parfitt), Sayed, 1942, Bul. Soc. Fouad $1^{\text {er }}$ Ent. 26: 96 . Misidentification.

Tenuipalpus granati Sayed, 1946, Bul. Soc. Fouad $1^{\text {er }}$ Ent. 30: 100 ; Pritchard and Baker, 1958, Univ. Calif. Publ. Ent. 14(3): 246.

Tenuipalpus granati is known only from Egypt on pomegranate and grape.

\section{Tenuipalpus quadrisetosus Lawrence}

Tenuipalpus quadrisetosus Lawrence, 1940, Jour. Ent. Soc. S. Afr. 3: 114; Lawrence, 1943, Trans. Roy. Soc. S. Afr. 30: 37; Baker and Pritchard, 
1953, Ann. Ent. Soc. Amer. 46: 319; Pritchard and Baker, 1958, Univ. Calif. Publ. Ent. 14(3) : 327.

Tenuipalpus gibbus Lawrence, 1943, Trans. Roy. Soc. S. Afr. 30: 42.

This species is known from Stella Wood, Durban, and Karkloof, near Pietermaritzburg, Natal, South Africa, on Cryptocarya woodi.

\section{GENUS DOLICHOTETRANYCHUS SAYED, 1938}

Dolichotetranychus Sayed, 1938, Bul. Mus. Hist. Nat. Paris (sér. 2), 10(6): 606.

Members of the genus Dolichotetranychus may be recognized by the three palpal segments and the slender, striate body. The mites are bright red and are usually found under the leaf sheaths or in the floral heads of grasses.

Although the genus occurs in Egypt (Sayed, 1938), the species known from there has not been identified. Two species are known from South Africa.

\section{Key to Species}

1. Female with one pair of anal setae; male with two sensory rods

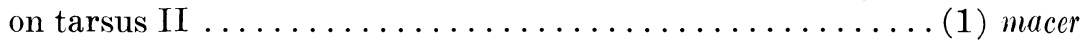

- Female with two pairs of anal setae; male with a single sensory rod on tarsus II ................ (2) australianus

\section{Dolichotetranychus macer Baker and Pritchard}

Dolichotetranychus macer Baker and Pritchard, 1956, Hilgardia 24(13): 372 ; Pritchard and Baker, 1958, Univ. Calif. Publ. Ent. 14(3) : 252.

This species is known only from Cape Province, South Africa, on Aristida namaquensis.

\section{Dolichotetranychus australianus (Womersley)}

Trichadenus autralianus̀ Womersley, 1943, Rec. S. Austral. Mus. 7: 245. Dolichotetranychus australianus (Womersley), Baker and Pritchard, 1956, Hilgardia 24(13) : 377 ; Pritchard and Baker, 1958, Univ. Calif. Publ. Ent. $14(3): 253$.

This species, originally described from South Queensland on Cynodon dactylon, was recorded from Kimberly, South Africa, on C. magennis by Baker and Pritchard (1956).

\section{GENUS RAOIELLA HIRST, 1924}

Raoiella Hirst, 1924, Ann. Mag. Nat. Hist. (ser. 9), 14: 522.

The genus Raoiella may be recognized by the two palpal segments and the smooth (except for punctae), rotund body. A single species is known to occur in Africa.

\section{Raoiella indica Hirst}

Raoiella indica Hirst, 1924, Ann. Mag. Nat. Hist. (ser. 9), 14: 522 ; Sayed, 1942, Bul. Soc. Fouad $1^{\text {er }}$ Ent. 26: 82; Pritchard and Baker, 1958, Univ. Calif. Publ. Ent. 14(3) : 256 ; Moutia, 1958, Bul. Ent. Res. 49: 61. 
Raoiella indica was originally described from India. Sayed (1942a) recorded collections in Egypt and the Sudan, and Moutia (1958) recorded this species from Mauritius. Hosts are palms, such as Cocos, Areca, Phoenix, and Dictyosperma.

\section{GENUS PHYLLOTETRANYCHUS SAYED, 1938}

Phyllotetranychus Sayed, 1938, Bul. Mus. Hist. Nat. Paris (sér. 2), 10(6): 602.

The genus Phyllotetranychus may be recognized by the globular body bearing large, fan-shaped, veined setae. There are two palpal segments. Two species are known, and both occur on palms.

\section{Key to Species}

1. Male with dorsocentral hysterosomal setae all similar; female with first pair of dorsal propodosomal setae very broad near middle ........................... (1) aegyptiacus

- Male with dorsocentral hysterosomal setae very dissimilar; female with first pair of dorsal propodosomal setae elongate-elliptical (2) romaine

\section{Phyllotetranychus aegyptiacus Sayed}

Phyllotetranychus aegyptium Sayed, 1938, Bul. Mus. Hist. Nat. Paris (sér. 2), 10: 602 .

Phyllotetranychus aegyptiacus Sayed, 1940, Bul. Soc. Fouad 1 $1^{\text {er }}$ Ent. 24: 250 ; Pritchard and Baker, 1958, Univ. Calif. Publ. Ent. 14(3) : 255.

This species is known only from Mataanah, Egypt, on date.

\section{Phyllotetranychus romaine Pritchard and Baker}

Phyllotetranychus romaine Pritchard and Baker, 1958, Univ. Calif. Publ. Ent. 14(3): 255.

Phyllotetranychus sp., Moutia, 1958, Bul. Ent. Res. 49 : 62.

This species is known only from Mauritius, on the under surfaces of leaves of Latania doddigesii.

\section{ACKNOWLEDGMENTS}

The senior author is indebted to J. Bruce Bredin of Wilmington, Delaware, for opportunity to make collections and field studies of plant feeding and associated mites in Africa. Through the kindness of Donald MacFarlane, collections in the British Museum (Natural History) were received for study, including the survey material collected by L. A. Moutia in Mauritius. 


\section{LITERATURE CITED}

ANDRÉ, MARC

1932a. Compte rendu d'une mission dans le Sud-Algérien (May 1932) pour l'étude d'un Acarien nuisible au Dattier. Paris Mus. Natl. d'Hist. Nat. Bul. (sér. 2) 4: 521-32.

1932b. Contribution à l'étude du "Bou-Faroua" Tétranyque nuisible au dattier en Algérie. Soc. d'Hist. Nat. de l'Afr. du Nord 23: 301-38.

1933. Note sur un Tétranyque nuisible au cottonier en Nouvelle-Calédonie. Paris Mus. Natl. d'Hist. Nat. Paris Bul. (sér. 2) 5: 302-8.

1954. Tétranyque nouveau, parasite de Cassia siamea Lam. et Grewia mollis Juss., à Dakar. Inst. Franc. d'Afr. Noire Bul. (sér. A) 16: 859-61.

1959. Note complémentaire sur Tetranychus neocaledonicus André. Acarologia 1(1): $53-55$.

Attiah, Hassan H.

1956. The genus Brevipalpus in Egypt. Soc. Ent. d'Egypte Bul. 40: 433-48.

BAKER, EDWARD W.

1949. The genus Brevipalpus (Acarina: Pseudoleptidae). Amer. Midland Nat. 42(2): $350-402$.

Baker, Edward W., and A. Earl Pritchard

1952. The geisenheyneri species group of the genus Brevipalpus (Acarina: Phytoptipalpidae). Ann. and Mag. Nat. Hist. (ser. 12) 5: 609-13.

$1953 a$. The family categories of tetranychoid mites, with a review of the new families Linotetranidae and Tuckerellidae. Ent. Soc. Amer. Ann. 46(2) : 243-58.

$1953 \mathrm{~b}$. A guide to the spider mites of cotton. Hilgardia $22(7): 203-34$.

1953c. A review of the false spider mite genus Tenuipalpus Donnadieu (Acarina: Phytoptipalpidae). Ent. Soc. Amer. Ann. 46: 317-36.

1954. A key to mites of the genus Pentamerismus, with descriptions of three new species (Acarina: Phytoptipalpidae). Wasmann Jour. Biol. 11: 353-66.

1956. False spider mites of the genus Dolichotetranychus (Acarina: Tenuipalpidae). Hilgardia 24(13): 357-81.

Banks, NaTHAN

1904. Four new species of injurious mites. New York Ent. Soc. Jour. 12: 53-56.

1917. New mites, mostly economic (Arach., Acar.). Ent. News 28: 193-99.

BerLese, ANTONio

1886. Acari dannosi alle piante coltivate. $31 \mathrm{pp}$. Padova.

1910. Lista di nuove specie e nuovi generi di acari. Redia 6(2) : 242-71.

1913. Acarotheca Italica. 221 pp. Tipografia di M. Ricci, Firenze, Italy.

Boisduval, A.

1867. Essai sur l'entomologie horticole. $648 \mathrm{pp}$. Paris.

Boudreaux, H. BRUCE

1956. Revision of the two-spotted spider mite (Acarina, Tetranychidae) complex, Tetranychus telarius (Linnaeus). Ent. Soc. Amer. Ann. 49: 43-48.

Buxton, M. A.

1921. Insect pests of dates and the date palm in Mesopotamia and elsewhere. Bul. Ent. Res. 11: 287-304.

Canestrini, G., and F. Fanzago

1876. Nuovi acari italiani (sec. ser.). Accad. Sei. Veneto-Trent. Istr. Padua Atti 5: $130-42$.

Donnadieu, A. L.

1875. Recherches pour servir à l'histoire des Tétranyques. Thèses, Faculté des Sciences de Lyon. 134 pp. Also published in: Soc. Linn. de Lyon Ann. (n. sér.) 22 (1876): 29-136.

DUFOuR, LÉON

1832. Description et figure du Tetranychus lintearicus, Arachnide nouvelle de la tribu des Acarides. Sei. Natl. Paris Ann. 25: 276. 
DUGÈs, ANT.

1834. Recherches sur l'ordre des Acariens en général et la famille des Trombidiés en EHARA, SHôzô particulier. Sci. Nat. Paris Ann. (sér. 2) 1: 5-46.

1956. Tetranychoid mites of mulberry in Japan. [Sapporo, Japan] Hokkaido Imp. Univ. Fac. Sci. Jour. (ser. 6, Zool.) 12: 499-510.

EwING, H. E.

1909. New species of Acarina. Amer. Ent. Soc. Trans. 35: 401-15.

1922. Three new species of peculiar and injurious spider mites. Washington Ent. Soc. Proc. 24: (4) : 104-08.

Eyndhoven, G. L. vaN

1956. Bryobia cristata (Dugès 1834) and Bryobia rubrioculus (Scheuten 1857) (Acar.) ; (Notulae ad Tetranychidas 3). Ent. Ber. 16: 45-46.

1957. Le Bryobia cristata de Dugès; Notulae ad Tetranychidas 5. Ent. Ber. 17: 171-83. GEIJSKES, D. C.

1939. Beiträge zur Kenntnis der europäischen Spinnmilben (Acari, Tetranychidae), mit besonderer Berücksichtigung der niederländischen Arten. Wageningen Landbouwhoogesch. Meded. 42(4): 1-68.

HIRST, STANLEY

1920. Revision of the English species of red spider (genera Tetranychus and Oligonychus). Zool. Soc. London Proc. 1920: 49-60.

1923. On some new or little-known species of Acari. Zool. Soc. Lond. Proc. 1923: 971-1000.

1924a. 4. Descriptions of new Acari, mainly parasitic on rodents. Zool. Soc. London Proc. 1924: 49-69.

1924b. LV.-On some new species of red spider. Ann. Mag. Nat. Hist. (ser. 9) 14(83): $522-27$.

1926. Deseriptions of new mites, including four new species of "red spider." Zool. Soc. London Proc. 1926: 825-41.

KLEIN, H. Z.

1936. Contributions to the knowledge of the red spiders in Palestine. Rehovoth, Israel

KoCH, C. L. Agr. Res. Sta. Bul. 21: 1-63.

1836. Deutsche Crustacea, Myriopoda, A rachnida, fase. 1.

LAWRENCE, R. F.

1940. Three new parasitic mites (Acarina) from South Africa. Ent. Soc. So. Afr. Jour. 3: $109-15$.

1943. New South African mites of the genus Tenuipalpus Donnadieu (Tetranychidae). Roy. Soc. So. Afr. Trans. 30:35-48.

LINNAEI, CAROLI

1758. Systema naturae, Vol. 1 (10th ed.). 824 pp. Stockholm.

LUCAS, $\mathrm{H}$.

1849. Histoire naturelle des animaux articulés. In: Exploration scientifique de l'Algerie pendant les années 1840, 1841, 1842; Sci. Phys. Zool. vol. 1, pp. 1-403. Paris. MCGREGOR, E. A.

1916. The citrus mite named and described for the first time. Ent. Soc. Amer. Ann. 9: $284-90$.

1939. The specific identity of the American date mite; description of two new species of Paratetranychus. Washington Ent. Soc. Proc. 41(9): 247-56.

1950. Mites of the family Tetranychidae. Amer. Midl. Nat. 44: 257-420.

Morgan, C. V. G., and N. H. ANDERSON

1957. Bryobia arborea $\mathrm{n}$. sp. and morphological characters distinguishing it from $B$. praetiosa Koch (Acarina: Tetranychidae). Canad. Ent. 89: 485-90.

MOUTIA, L. ANDRÉ

1958. Contribution to the study of some phytophagous Acarina and their predators in Mauritius. Bul. Ent. Res. 49: 59-75. 
MÜLLER, O. F.

1776. Zoologiae danicae Prodromus. 282 pp. Copenhagen, Denmark.

MURRAY, ANDREW

1877. Economic entomology, Aptera. 433 pp. Chapman and Hall, London.

NiETNER, J.

1861. Observations on the enemies of the coffee tree in Ceylon. $31 \mathrm{pp}$. Ceylon.

Oudemans, A. C.

1931. Acarologische aanteekeningen CVII. Ent. Ber. 8(178) : 221-36.

Pritchard, A. EARL, and Edward W. Baker

1952. The false spider mites of California (Acarina: Phytoptipalpidae). Univ. California Pubs. Ent. 9(1) : 1-93.

1955. A revision of the spider mite family Tetranychidae. Pac. Coast Ent. Soc. Mem. 2: $1-472$.

1958. The false spider mites (Acarina: Tenuipalpidae). Univ. California Pubs. Ent. $14(3): 175-274$.

Rahman, Khan A., and Amar Nath SaPra

1940. Mites of the family Tetranychidae from Lyallpur with descriptions of four new species. Indian Acad. Sci. Proc. (ser. B) 11: 177-96.

1946. On the biology of the vegetable mite (Tetranychus cucurbitae Rahman and Sapra: fam. Tetranychidae). Indian Jour. Agr. Sci. 15(3) : 124-30 (1945).

RECK, G. P.

1952. Onekotorich osnovach klassificatsii tetranychovich kleshchei. Soobsh. Akad. Nauk Gruz. S.S.R. 13(7) : 419-25.

SAYED, M. TAHER

1938. Sur une nouvelle sous-famille et deux nouveaux genres de Tétranyques (Acariens). Paris Mus. d'Hist. Nat. Bul. (sér. 2) 10: 601-10.

1940. Sur une nouvelle sous-famille et deux nouveaux genres de Tétranyques (Acarina). Soc. Fouad 1 ${ }^{\text {er }}$ Ent. Bul. 24: 250.

1942a. Contribution to the knowledge of the Acarina of Egypt: I. The genus Raoiella Hirst (Pseudotetranychinae - Tetranychidae). Soc. Fouad $1^{\text {er }}$ Ent. Bul. 26: 81-91.

1942b. Contribution to the knowledge of the Acarina of Egypt: II. The genus Tenuipalpus Donnadieu [Tetranychidae]. Soc. Fouad 1 $1^{\text {er }}$ Ent. Bul. 26: 93-113.

1942c. Contribution to the knowledge of the Acarina of Egypt: III. The genus Phytoptipalpus Trägårdh. Soc. Fouad $1^{\text {er }}$ Ent. Bul. 26: 115-23.

1942d. Contribution to the knowledge of the Acarina of Egypt: IV. The genus Anychus McGregor (Tetranychidae). Soc. Fouad $1^{\text {er }}$ Ent. Bul. 26: 125-27.

1946a. Contribution to the knowledge of the Acarina of Egypt: V. Five new species of Tetranychidae. Soc. Fouad $1^{\text {er }}$ Ent. Bul. 30: 79-97.

1946b. Deseription of Tenuipalpus granati nov. spec. and Brevipalpus pyri nov. spec. Soc. Fouad 1 $1^{\text {er }}$ Ent. Bul. 30: 99-104.

1946c. The genus Anychus McGregor in Egypt and the Sudan. Soc. Fouad $1^{\text {er }}$ Ent. Bul. 30: $143-48$.

1950. Description of a new genus and two new species of the family Tenuipalpidae Sayed (Acarina). Eighth Internatl. Congr. Ent. Proc., pp. 1018-21.

Scheuten, A.

1857. Einiges über Milben. Arch. Naturg. 23(1) : 104-12.

TRÄGÅRDH, IVAR

1904. Acariden aus Agypten und dem Sudan, 1. Results of the Swedish Zoological Expedition to Egypt and the White Nile 1901, 20: 1-124.

1915. Bidrag till kännedomen om spinnvalstren (Tetranychus Duf.). Centralanst. för Försöksv. på Jordbruksområdet Meddel. 109 (Ent. avd 20): 1-60; and: K. Landtbr.-Akad., Stockholm, Handl. 54: 259-310. 
The journal Hilgardia is published at irregular intervals, in volumes of about 600 pages. The number of issues per volume varies.

Subscriptions are not sold. The periodical is sent as published only to libraries, or to institutions in foreign countries having publications to offer in exchange.

You may obtain a single copy of any issue free, as long as the supply lasts; please request by volume and issue number from:

\author{
Agricultural Publications \\ 207 University Hall \\ 2200 University Ave. \\ Berkeley 4, California
}

The limit to nonresidents of California is 10 separate issues on a single order. A list of the issues still available will be sent on request. 